\author{
Universidade de São Paulo \\ Faculdade de Economia, Administração e Contabilidade \\ Departamento de Economia \\ Programa de Pós-graduação em Economia
}

Fatores determinantes do investimento e o papel das mudanças institucionais na acumulação de capital e no crescimento do Brasil

Ana Lelia Magnabosco

Orientadora: Profa. Dra. Fabiana Fontes Rocha 
Prof. Dr. Marco Antonio Zago

Reitor da Universidade de São Paulo

Prof. Dr. Adalberto Américo Fischmann

Diretor da Faculdade de Economia, Administração e Contabilidade

Prof. Dr. Hélio Nogueira da Cruz

Chefe do Departamento de Economia

Prof. Dr. Márcio Issao Nakane

Coordenador do Programa de Pós-Graduação em Economia 
Ana Lelia Magnabosco

\title{
Fatores determinantes do investimento e o papel das mudanças institucionais na acumulação de capital e no crescimento do Brasil
}

\begin{abstract}
Tese apresentada ao Programa de Pós-graduação em Economia da Faculdade de Economia, Administração e Contabilidade da Universidade de São Paulo, para obtenção do título de Doutor em Ciências.
\end{abstract}

Orientadora: Profa. Dra.

Fabiana Fontes Rocha

Versão Original

São Paulo

2015 
FICHA CATALOGRÁFICA

Elaborada pela Seção de Processamento Técnico do SBD/FEA/USP

Magnabosco, Ana Lelia

Fatores determinantes do investimento e o papel das mudanças institucionais na acumulação de capital e no crescimento do Brasil / Ana Lelia Magnabosco. - São Paulo, 2015.

$201 \mathrm{p}$.

Tese (Doutorado) - Universidade de São Paulo, 2015.

Orientador: Fabiana Fontes Rocha.

1. Formação de capital 2. Crédito 3. Economia institucional 4. Crescimento e desenvolvimento 5. Investimentos I. Universidade de São Paulo. Faculdade de Economia, Administração e Contabilidade. II. Título.

CDD - 332.0415 
À memória de meu avô Lanis Fernando Magnabosco 



\section{Agradecimentos}

À Fundação de Amparo à Pesquisa do Estado de São Paulo, pela concessão da bolsa de doutorado e pelo apoio financeiro para a realização desta pesquisa.

Aos professores Pedro Garcia Duarte, Vera Lúcia Fava e Joaquim Guilhoto, cujos cursos foram fundamentais para o desenvolvimento metodológico desta tese. Aos professores Raul Cristóvão dos Santos e Gilberto Tadeu Lima pelos preciosos ensinamentos na área de desenvolvimento econômico.

Aos membros da banca de qualificação do projeto, os professores Leda Maria Paulani e Gilberto Tadeu Lima, agradeço pelas críticas fundamentais para o desenvolvimento do projeto de pesquisa.

Aos membros da banca de qualificação, os professores Maria Dolores Montoya Diaz e Gilberto Tadeu Lima, agradeço pelas críticas fundamentais para o desenvolvimento da versão final desta tese.

Aos professores Jorge Pires, da Fundação Getulio Vargas, e Rita Markovits-Somogyi, da Universidade de Tecnologia e Economia de Budapeste, pelas discussões sobre fronteira estocástica. À professora Christine Whitehead, da London School of Economics, pelas discussões sobre investimento habitacional e o papel dos subsídios no crédito.

À professora Fabiana Fontes Rocha, que teve muita paciência e imensa dedicação na orientação desta tese.

Ao funcionário, Pinho, pelo imenso apoio nesses anos.

Aos amigos, Rainer Hartman, Gustavo Lira, Érica Camargo, Jorge Shy, Laura Marcelini, Inês Magalhães, José Luiz Fernandes, André Gal Mountian e Aleix Altimiras meus agradecimentos pelas conversas e cantorias.

Ao meu querido esposo Fernando Garcia de Freitas, pelas incontáveis discussões sobre o tema, pela enorme ajuda na revisão da tese e pela paciência e compreensão durante a elaboração do trabalho.

Aos meus pais, avó e irmã que, mesmo de longe, sempre torceram por mim e me incentivaram. 



\section{Resumo}

MAGNABOSCO, A. L. Fatores determinantes do investimento e o papel das mudanças institucionais na acumulação de capital e no crescimento do Brasil. Tese (Doutorado) - Faculdade de Economia, Administração e Contabilidade, Universidade de São Paulo, 2015.

Esta tese analisa os fatores determinantes do investimento e seus efeitos sobre o crescimento econômico das nações, em geral, e do Brasil, em particular. O foco da discussão na acumulação de capital decorre do fato de que $2 / 3$ do crescimento econômico brasileiro foi devido a esse processo. Para avaliar a questão, a tese combina três abordagens complementares: a visão teórica, a avaliação histórica e a análise econométrica. $\mathrm{O}$ trabalho está dividido em duas partes: a primeira trata dos determinantes teóricos do investimento e faz a análise econométrica com dados internacionais. A segunda traz a análise do crédito e do investimento no Brasil, reunindo as abordagens histórica e econométrica. A visão teórica fundamenta a análise e define as variáveis-chave que afetam o investimento: juros, crédito de longo prazo, retorno do capital e preço dos ativos. Parte-se da visão de que as mudanças institucionais afetam o investimento porque buscam preservar o retorno dos investidores e dos bancos. A análise econométrica avalia o comportamento dos investimentos em três níveis: macroeconômico internacional, macroeconômico brasileiro e setorial brasileiro. A análise internacional considera um painel com dados de 39 economias entre 1995 e 2011. São utilizadas as técnicas de cointegração em painel conforme as metodologias de Kao (1999) e Pedroni (1999, 2004). A avaliação econométrica do agregado da economia brasileira é feita com dados anuais entre 1953 e 2013 e utiliza as técnicas de cointegração de Johansen (1995) e de Gregory e Hansen (1996), para avaliar a possibilidade de quebras estruturais. A análise desagregada é feita com base em dados de 31 setores de atividade econômica entre 1995 e 2009 e nas técnicas de cointegração em painel. Os resultados das avaliações econométricas de painel (internacional e setorial) mostram relações estáveis e positivas entre investimento, crédito e retorno do capital, e relações negativas entre investimento, taxa de juros de longo prazo e taxa real de câmbio, corroborando os princípios teóricos. Os resultados para o agregado da economia brasileira (séries de tempo) confirmam haver relações estáveis e positivas entre investimento, crédito e retorno do capital, mesmo na presença de quebra estrutural. A abordagem histórica analisa a constituição dos mecanismos de financiamento ao investimento no Brasil e suas principais alterações ao longo da história. São avaliados os papéis do crédito hipotecário, do mercado acionário, da implantação do Banco Nacional de Desenvolvimento Econômico (BNDE) e do Banco Nacional da Habitação (BNH) e das reformas institucionais dos anos 1960. Também são descritas as principais mudanças institucionais ocorridas nas décadas de 1990, 2000 e 2010. A interpretação histórica do contexto institucional brasileiro e os resultados das análises econométricas sugerem que as mudanças institucionais ocorridas ao longo da história econômica do país foram fundamentais para a retomada do crédito de longo prazo na economia. Elas também contribuíram para amenizar a queda do retorno do capital.

Palavras-chave: formação de capital, investimentos, crédito, economia institucional e crescimento e desenvolvimento. 



\begin{abstract}
MAGNABOSCO, A. L. The determining factors of investment and the role of institutional changes in capital accumulation and growth in Brazil. Doctoral dissertation - Faculdade de Economia, Administração e Contabilidade, Universidade de São Paulo, 2015.
\end{abstract}

This doctoral dissertation analyzes the determining investment factors and their effects on economic growth of the nations in general and on Brazil in particular. This discussion focuses especially on capital accumulation because this process has accounted for two thirds of Brazilian economic growth. To investigate this question, this study combines three complementary approaches: a theoretical vision, a historical assessment, and an econometric analysis. The dissertation is divided into two parts. The first discusses the theoretical determining factors of investment and presents an econometric analysis using international data. The second analyzes credit and investment in Brazil, combining historical and econometric approaches. The theoretical overview provides a basis for the analysis and defines the key variables that influence investment: interest rates, longterm credit, return of capital, and the price of assets. This investigation is based on the premise that institutional changes affect investment because they attempt to preserve the return of both investors and banks. The econometric analysis evaluates the behavior of investment on three levels: international macroeconomic, Brazilian macroeconomic, and Brazilian industries. The international analysis considers a panel of 39 economies containing data from 1995 to 2011. This study employed panel cointegration techniques based on the methods described by Kao (1999) and Pedroni (1999, 2004). The econometric evaluation of the aggregate of the Brazilian economy uses annual data from 1953 to 2013 and cointegration techniques described by Johansen (1995) and by Gregory and Hansen (1996), to assess the possibility of structural changes. The disaggregated analysis uses data from 31 economic industries, from 1995 to 2009, and panel cointegration techniques. The results of the panel econometric evaluations (international and sector) show stable and positive relations between investment, credit and return of capital, and negative relations between investment, long-term interest rate, and real exchange rate, confirming the theoretical principles. The results for the aggregate of the Brazilian economy (time series) confirm positive and stable relations between investment, credit, and return of capital, even when there is a structural change. The historical overview investigates the creation of investment financing mechanisms in Brazil and how they have changed over time. This dissertation analyzes mortgage securities, equity market, the establishment of the National Economic Development Bank (BNDE) and the National Housing Bank (BNH), and the institutional reforms of the 1960s. It also describes the main institutional changes of the 1990s, 2000s and 2010s. The historical interpretation of the Brazilian institutional setting and the findings of the econometric analyses suggest that the institutional changes that have taken place over Brazil's economic history were essential in making long-term credit again available in the economy. They have also helped to minimize the decreasing trends in the returns of capital.

Keywords: capital formation, investment, credit, institutional economy, and growth and development. 



\section{Índice}

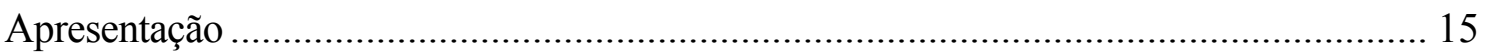

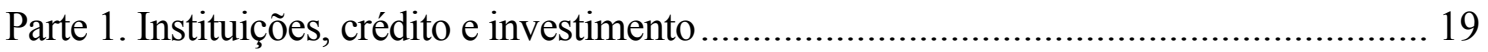

Capítulo 1. Visões teóricas dos determinantes do investimento ....................................... 21

1.1 A influência dos juros e do retorno do capital.................................................. 22

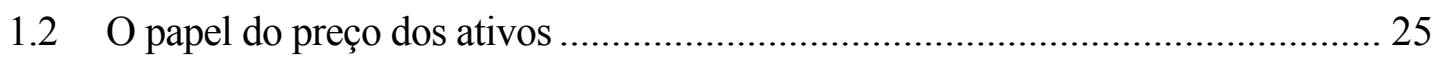

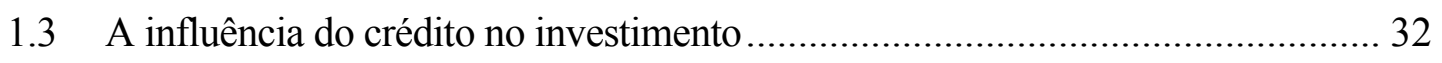

Capítulo 2. Mudança institucional, acumulação de capital e crescimento ...................... 37

2.1 A visão teórica do papel das mudanças institucionais........................................ 38

2.2 Instituições, retorno dos bancos e a oferta de crédito ........................................ 42

2.3 Acumulação de capital e crescimento.............................................................. 48

2.3.1 Instituições, retorno do capital e investimento ................................................. 48

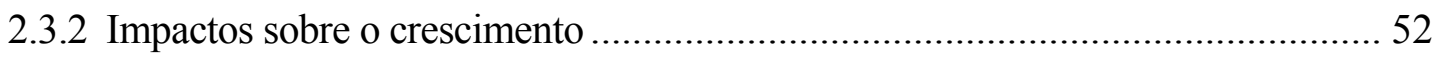

Capítulo 3. Crédito e investimento no contexto mundial ............................................... 55

3.1. A literatura empírica sobre a relação entre crédito e investimento .................. 57

3.2. Oferta de crédito e investimento agregado no mundo.................................... 60

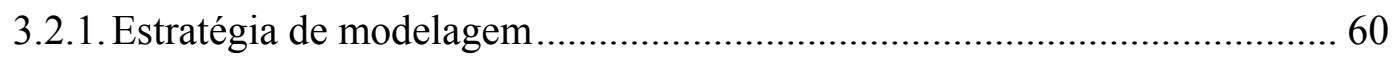

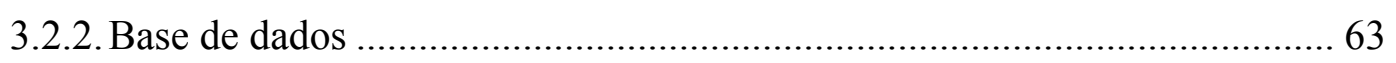

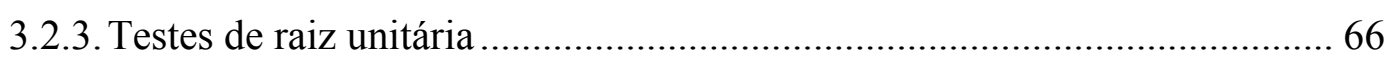

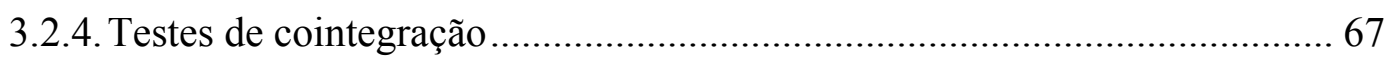

3.3. Os efeitos do retorno esperado do capital e

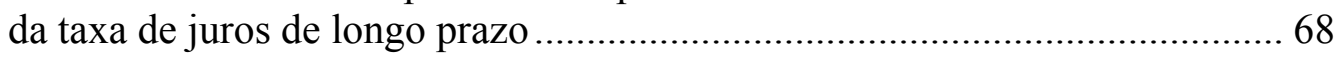

3.4. Efeitos dos determinantes do investimento na acumulação de capital e no crescimento econômico...................................... 71

Parte 2. Mudanças institucionais, crédito, investimento e crescimento no Brasil .............. 75

Capítulo 4. Uma abordagem histórica do financiamento do investimento no Brasil .......... 77

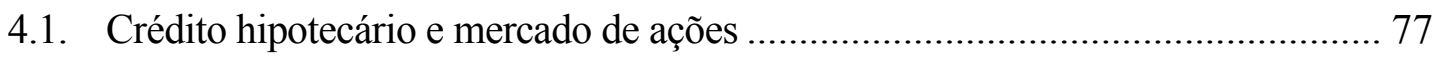

4.1.1. O financiamento da economia cafeeira e o início da industrialização......... 77

4.1.2. O crédito hipotecário e a crise de 1929 .................................................... 80

4.2. A fundação do financiamento de longo prazo.................................................... 84

4.2.1. Necessidade de mudanças e o BNDE ......................................................... 84

4.2.2. O financiamento de longo prazo e o Plano de Metas ................................ 87 
4.3. A reforma financeira dos anos 1960 e seu

impacto sobre o desenvolvimento

4.3.1. A reformulação do Sistema Financeiro Nacional ........................................ 89

4.3.2. Ascenção e queda do crédito e do investimento........................................ 92

Capítulo 5. As mudanças institucionais na economia brasileira desde 1990 ................. 97

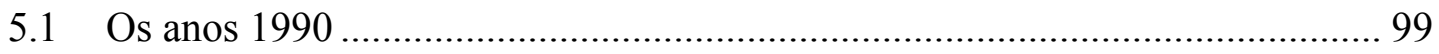

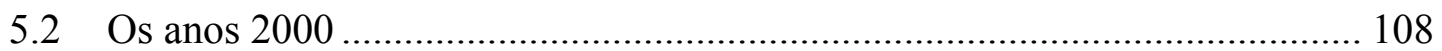

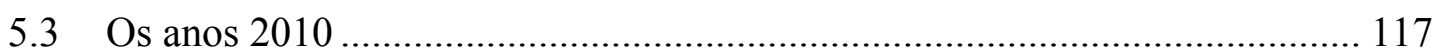

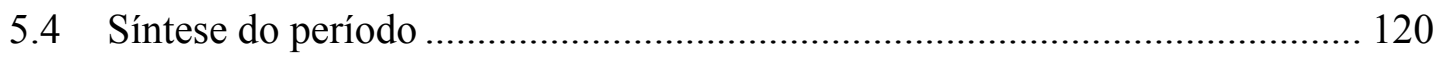

Capítulo 6. A influência do crédito no investimento agregado .................................... 123

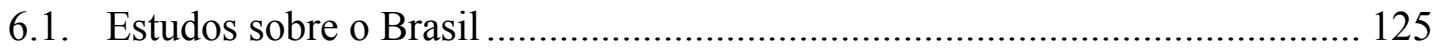

6.2. Oferta de crédito e investimento agregado no Brasil ................................... 129

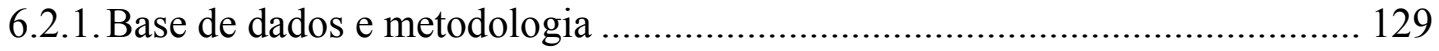

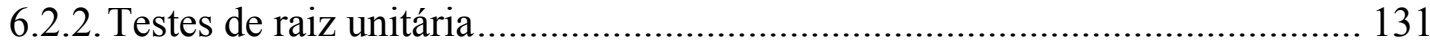

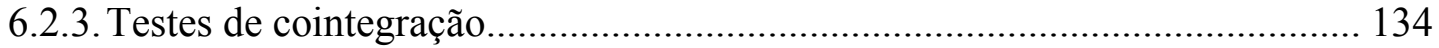

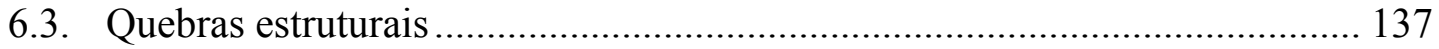

6.4. Os efeitos na acumulação de capital e no crescimento econômico ................. 139

Capítulo 7. Crédito e investimento setoriais no Brasil ................................................. 145

7.1. Oferta de crédito e investimento agregado setorial ..................................... 147

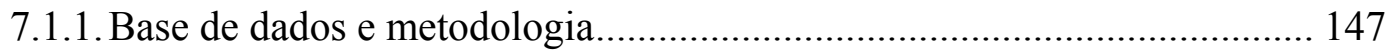

7.1.2. Resultados dos testes de raiz unitária ...................................................... 150

7.1.3. Resultados dos testes de cointegração em painel ..................................... 151

7.2. Os efeitos da taxa de juros de longo prazo e do retorno esperado do capital.................................................................... 152

7.3. Efeitos dos determinantes do investimento na acumulação de capital e no crescimento econômico........................................ 155

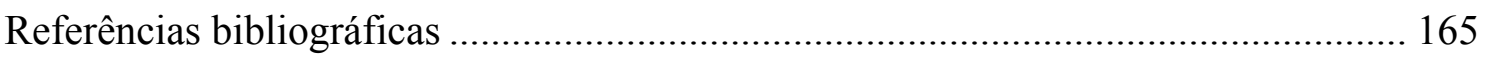

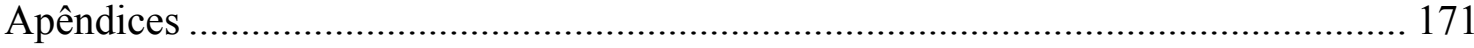

Apêndice 3.1 Séries de retorno esperado do capital ............................................. 171

Apêndice 3.2. Descrição dos testes de raiz unitária.................................................. 173

Apêndice 3.3. Descrição dos testes de cointegração ............................................... 176

Apêndice 3.4 Tabelas complementares de cointegração ........................................ 179

Apêndice 3.5 Tabelas complementares de contabilidade de crescimento ................ 180

Apêndice 4.1 Crédito Hipotecário no Brasil, 1909 a 1934 ..................................... 184

Apêndice 4.2 Crédito total do Banco do Brasil, 1938 a 1945 ................................ 185

Apêndice 4.3 Fontes de recursos e desembolsos do BNDE .................................... 186 
Apêndice 4.4 O BNDE e a Reforma Financeira

Apêndice 6.1 Resultados da fronteira para cálculo do retorno esperado do capital......

Apêndice 6.2. Descrição dos testes de raiz unitária e de cointegração

Apêndice 6.3. Tabelas complementares da análise de séries de tempo

Apêndice 6.4 Descrição do teste de raiz unitária e de cointegração com quebra estrutural.

Apêndice 6.5. Tabelas complementares da análise com quebra estrutural.

Apêndice 7.1. Tabelas complementares da análise do painel setorial

Apêndice 7.2. Resultados da fronteira para cálculo do retorno esperado do capital.

Apêndice 7.3. Tabelas complementares de cointegração 



\section{Apresentação}

Esta tese analisa os fatores determinantes do investimento e seus efeitos sobre o crescimento econômico das nações, em geral, e do Brasil, em particular. A ideia de centrar o foco da discussão no processo de acumulação de capital vem do fato de que o crescimento econômico brasileiro foi fortemente impulsionado por essa variável. Conforme ilustra a tabela abaixo, a taxa de acumulação de capital foi responsável por $64,6 \%$ da taxa de crescimento média do PIB brasileiro entre 1953 e 2013 , que foi de $4,8 \%$ ao ano. Note-se que essa contribuição foi bastante elevada em todos os subperíodos destacados na tabela.

Tabela 1. Decomposição do Crescimento do PIB, Brasil, 1953 a 2013 (\% ao ano)

\begin{tabular}{lrrrr}
\hline Periodo & $g_{\curlyvee}$ & $g_{A}$ & $\lambda_{K}{ }^{*} g_{K}$ & $\lambda_{L}{ }^{*} g_{N}$ \\
\hline 1953 a 1967 & $6,4 \%$ & $1,0 \%$ & $4,1 \%$ & $1,3 \%$ \\
1967 a 1980 & $8,9 \%$ & $2,7 \%$ & $4,8 \%$ & $1,4 \%$ \\
1980 a 1994 & $1,9 \%$ & $-2,2 \%$ & $2,6 \%$ & $1,5 \%$ \\
1994 a 2003 & $2,2 \%$ & $-0,1 \%$ & $1,3 \%$ & $0,9 \%$ \\
2003 a 2013 & $3,7 \%$ & $1,4 \%$ & $1,7 \%$ & $0,6 \%$ \\
\hline $\mathbf{1 9 5 3}$ a 2013 & $\mathbf{4 , 8} \%$ & $\mathbf{0 , 5} \%$ & $\mathbf{3 , 1 \%}$ & $\mathbf{1 , 2} \%$ \\
\hline
\end{tabular}

Fonte: IBGE e Anexo 6.1 da tese. Cálculos próprios. $\lambda_{K}$ e $\lambda_{N}$ são as participações do capital e do trabalho na renda $\mathrm{e}$ $g_{Y}, g_{A}, g_{K}$ e $g_{N}$ são, respectivamente, as taxas de crescimento econômico, aumento da produtividade, acumulação de capital e expansão da força de trabalho.

Para avaliar essa questão, a tese combina três abordagens complementares: uma visão teórica, a avaliação histórica e a análise econométrica. A visão teórica fundamenta a análise e define as variáveis-chave que afetam o investimento: juros, crédito de longo prazo, retorno do capital e preço dos ativos. Essas variáveis são utilizadas para explicar o comportamento do investimento em diferentes países, considerando um painel com dados de 39 economias entre 1995 e 2011.

Além disso, a análise teórica identifica o papel de mudanças institucionais no mercado de crédito e na rentabilidade dos negócios na economia, dois canais pelos quais as instituições influenciam a formação de capital. Essa avaliação auxilia na interpretação histórica da evolução do crédito, do investimento e do crescimento no Brasil. A análise econométrica do comportamento do crédito, do retorno do capital e do investimento no Brasil complementa a visão histórica. A avaliação econométrica do Brasil é feita tendo por referência duas bases de dados: um banco de séries de tempo entre 1953 e 2013; e um painel de 31 setores de atividade econômica entre 1995 e 2009.

O trabalho está dividido em duas partes: a primeira trata dos determinantes teóricos do investimento e faz a análise econométrica com o painel internacional. A segun- 
da traz a análise do crédito e do investimento no Brasil, reunindo as abordagens histórica e econométrica.

\section{Parte 1. Instituições, crédito e investimento}

O primeiro capítulo da tese traz uma revisão da literatura sobre os determinantes do investimento. Ela inicia com a exposição das visões keynesiana e neoclássica sobre o tema, apresenta as teorias dinâmicas de acumulação de capital e discute o modelo de mercado de capitais em que o comportamento econômico dos intermediários financeiros influencia a oferta de crédito.

A análise teórica é complementada no Capítulo 2, onde é proposto um modelo que analisa a influência de mudanças institucionais sobre o retorno do capital e o risco de crédito e o efeito dessas variáveis sobre o investimento. A premissa básica estabelece que as mudanças institucionais afetam o investimento por dois canais: (i) elas interferem nos custos de transação das atividades econômicas, alterando o retorno do capital dos empreendedores; e (ii) elas reorientam o crédito, na medida em que alteram o comportamento dos intermediários financeiros.

O modelo teórico também discute o papel dos subsídios ao investimento, uma variável muito importante no caso do Brasil por conta dos modelos de crédito do BNDES e do BNH e, mais recentemente, pelos programas PAC e PMCMV. Por fim, a análise teórica decompõe o crescimento econômico e estabelece uma medida da contribuição dos fatores determinantes do investimento sobre o crescimento econômico das nações.

O Capítulo 3 analisa como o crédito, o retorno do capital, a taxa de juros de longo prazo e o preço dos ativos afetaram o investimento internacional entre 1995 e 2011. São utilizadas as técnicas de cointegração em painel conforme as metodologias de Kao (1999) e Pedroni $(1999,2004)$. A análise evidencia relações estáveis e positivas do investimento com o crédito e o retorno do capital, e negativas, no caso da taxa de juros de longo prazo e do custo de reposição do capital relativamente aos preços médios. Essas evidências corroboram as conclusões do modelo teórico proposto no Capítulo 2. Os efeitos da evolução dessas variáveis sobre o processo de acumulação de capital e o crescimento econômico desses países são analisados na seção final.

Esses resultados também sugerem que a análise empírica e histórica da acumulação de capital no Brasil deve partir de uma avaliação das condições determinantes do investimento. Como a oferta de crédito e o retorno do capital estão, ao menos do ponto de vista 
teórico, relacionados com mudanças institucionais, a análise histórica das regras que regem o crédito e a rentabilidade dos negócios também é indispensável.

\section{Parte 2. Mudanças institucionais, crédito, investimento e crescimento no Brasil}

A Parte 2 reúne os capítulos que analisam o caso brasileiro. O Capítulo 4 analisa a constituição dos mecanismos de financiamento ao investimento no Brasil e suas principais alterações ao longo da história - da segunda metade do século XIX, quando são formadas as bases do financiamento de longo prazo no país, até o final dos anos 1980, período de crise profunda e desarticulação da intermediação financeira. São avaliados os papéis do crédito hipotecário, do mercado acionário, da implantação do Banco Nacional de Desenvolvimento Econômico (BNDE) e das reformas institucionais dos anos 1960.

A partir da década de 1990, foram implantadas reformas institucionais que buscavam recuperar o crédito e alavancar o investimento no país. Algumas dessas mudanças institucionais reduziram o risco dos bancos e dos credores, permitindo uma elevação do crédito. Outras mudanças institucionais afetaram o retorno do capital de setores econômicos específicos, com efeito sobre a acumulação de capital. O Capítulo 5 descreve as principais mudanças institucionais ocorridas nas décadas de 1990, 2000 e 2010. É importante notar que as mudanças tiveram efeito em praticamente todos os setores de atividade econômica. Assim, o conjunto dessas mudanças alterou a trajetória do investimento e elevou o crescimento econômico do Brasil nos últimos dez anos.

Os Capítulos 6 e 7 trazem as avaliações econométricas dos determinantes do investimento na economia brasileira - séries temporais e painel setorial. A análise de séries de tempo utiliza a técnica de cointegração de Johansen (1995) para uma base de dados com informações entre 1953 a 2013. É analisada, também, a possibilidade de quebras estruturais - metodologia de Gregory e Hansen (1996). Os resultados para o agregado da economia brasileira (Capítulo 6) confirmam haver relações estáveis e positivas entre investimento, crédito e retorno do capital. Os resultados se mantêm na presença de quebra estrutural.

A análise setorial feita no Capítulo 7 utiliza a técnica de cointegração em painel, seguindo as metodologias de Kao (1999) e Pedroni (1999, 2004), aos moldes do que foi desenvolvido no Capítulo 3. O período de análise vai de 1995 a 2009 e são considerados 31 setores de atividade econômica. Os resultados mostram relações estáveis e positivas entre investimento, crédito e retorno do capital, e relação negativa entre investimento e taxa de juros de longo prazo e taxa real de câmbio. 
As análises de contabilidade de crescimento, estimando os efeitos dos fatores determinantes do investimento sobre a acumulação de capital e o crescimento econômico no Brasil, são feitas ao final de cada capítulo: no Capítulo 6, sobre as bases de séries de tempo (agregado da economia) e, no Capítulo 7, sobre o painel setorial. Essa medição segue as equações teóricas derivadas no Capítulo 2 e a análise empreendida no Capítulo 3. Os resultados mostram que, de fato, as contribuições da evolução do crédito e do retorno do capital foram bastante significativas para a taxa de crescimento do estoque de capital nos anos 2000. A análise do banco de dados setorial, que traz informações sobre a evolução da taxa de juros de longo prazo, permite destacar o papel fundamental da redução dos juros de longo prazo empreendida desde 2003 sobre o investimento.

A interpretação histórica do contexto institucional brasileiro e os resultados das análises econométricas sugerem que as mudanças institucionais ao longo da história econômica do país, com destaque para aquelas ocorridas em meados dos anos 1960 e a partir da década de 1990, foram fundamentais para a retomada do crédito de longo prazo na economia. Elas também contribuíram para amenizar a queda da taxa de retorno do capital.

Ao final, a conclusão desta tese faz uma discussão sobre os vários aspectos da formação de capital, que foram abordados dos pontos de vista teórico, econométrico e histórico, e traz a reunião desses pontos numa visão perspectiva do desenvolvimento nacional. 
Parte 1.

Instituições, crédito e investimento 


\section{Capítulo 1}

\section{Visões teóricas dos determinantes do investimento}

Este capítulo expõe as principais abordagens teóricas sobre os determinantes do investimento. Ela inicia com a exposição das visões keynesiana e neoclássica sobre o tema, apresenta e discute as teorias dinâmicas de acumulação de capital e o modelo de mercado de capitais que ressalta a influência do comportamento econômico dos intermediários financeiros na disponibilização de crédito. Essa revisão da literatura teórica possibilita a triagem das principais variáveis que afetam o investimento, as quais serão empregadas na análise empírica realizada nos próximos capítulos. Ela também serve de base para o desenvolvimento, no capítulo seguinte, de um modelo teórico que avalia os efeitos de mudanças institucionais sobre a acumulação de capital e o crescimento econômico.

Keynes (1936) foi um dos principais autores a se preocupar com as decisões de investimento e sua influência na economia. Ele observou que o investimento depende da eficiência marginal do capital relativa a uma taxa de juros, variável que reflete o custo de oportunidade dos fundos de investimento. A abordagem neoclássica, seguindo a síntese proposta no trabalho de Jorgenson (1967), fundamenta uma função investimento a partir da maximização do valor presente da firma, ou da maximização dos lucros, e demonstra que é possível derivar um modelo dinâmico do comportamento do investimento a partir das hipóteses do modelo neoclássico.

A segunda seção discute o desenvolvimento das terias dinâmicas do investimento nas visões de Tobin (1969) e Blanchard (1981). O primeiro autor ressaltou a importância da valorização do capital sobre o investimento. Blanchard (1981) aplicou o conceito de expectativas racionais, o qual está baseado na ideia de previsibilidade perfeita, para avaliar a evolução do preço dos ativos de empresa. Suas ideias serviram, posteriormente, ao desenvolvimento de modelos dinâmicos de equilíbrio parcial que avaliam o investimento setorial, como é o caso do modelo de investimento imobiliário de Muth (1960), Sheffrin (1985) e Muth e Goodman (1989).

A seção final avalia a influência do crédito sobre o investimento seguindo a análise de Stiglitz e Weiss (1981). Os autores trabalham com um modelo de mercado de capitais com informação imperfeita no qual os bancos utilizam a taxa de juros e a exigência de colateral na dívida como mecanismos de proteção da inadimplência dos tomadores de empréstimo. Essa análise indica que o montante de crédito é determinado pela oferta dos bancos, o 
que implica que pode haver racionamento de crédito no equilíbrio. Assim, o volume do crédito concedido restringe o investimento de maneira direta, independentemente da influência da taxa de juros e da disponibilidade de poupança da economia.

\subsection{A influência dos juros e do retorno do capital}

Keynes (1936) introduziu o conceito de eficiência marginal do capital, o qual é fundamental na análise dos determinantes do investimento: “(...) defino a eficiência marginal do capital como sendo a taxa de desconto que tornaria o valor presente do fluxo de anuidades das rendas esperadas desse capital, durante toda a sua existência, exatamente igual ao seu preço de oferta". (Keynes, 1936; p.115). A renda esperada do investimento durante a vida útil do bem de capital vem das receitas das vendas, deduzidas as despesas correntes necessárias à obtenção dos produtos. O preço de oferta do bem de capital é definido como o preço necessário para induzir o fabricante a produzir uma nova unidade desse capital, ou seja, é o seu custo de reposição.

Uma primeira relação importante é a que existe entre a eficiência marginal do capital e o volume de investimento. Quanto maior o investimento, menor a eficiência marginal do capital. Isso ocorre por dois motivos: conforme aumenta o investimento e, portanto, o ritmo de acumulação de capital, cai o fluxo de renda esperado e aumenta o preço de oferta em razão da pressão sobre as fábricas produtoras do bem de capital.

As empresas investem o montante de capital que iguala a eficiência marginal à taxa de juros. Até essa igualdade, é vantajoso para o empresário aplicar o capital próprio ou tomar recursos emprestados para investir. Além desse equilíbrio, a empresa teria prejuízo com o investimento. A partir desses conceitos é possível definir a curva de eficiência marginal do capital, também chamada de curva de demanda por investimento. Essa curva relaciona a taxa de investimento agregado com a taxa de juros. Nessa abordagem, o investimento cai conforme aumenta a taxa de juros.

Para Keynes, como a eficiência marginal do capital depende da renda esperada, a expectativa de modificações no valor da moeda influi sobre o volume de produção presente. A expectativa de uma baixa no valor da moeda estimula o investimento e, em consequência, o emprego em geral, porque eleva a demanda por investimentos. Keynes (1936), ressalta que o erro consiste em supor que as variações esperadas no valor da moeda atuam diretamente sobre a taxa de juros, em vez de fazê-lo sobre a eficiência marginal do capital: a expectativa de elevação dos preços tem um efeito estimulante sobre o investimento não por- 
que faz subir a taxa de juros, mas porque eleva a expectativa de valor presente dos fluxos de rendas e, portanto, aumenta a eficiência do investimento.

Assim, um conceito fundamental na teoria da decisão de investir é o de expectativas. Segundo Keynes (1936), o estado de expectativas quanto ao longo prazo, o qual serve de base para a tomada de decisões, não depende exclusivamente dos prognósticos mais prováveis que o investidor pode formular sobre os fluxos futuros de rendas. Depende também da confiança que se tem em tal prognóstico. O estado de confiança é um dos principais fatores que determinam a escala da eficiência marginal do capital.

Para Keynes (1936), é difícil fazer cálculos das rendas esperadas de um investimento, pois a base do conhecimento é precária. Os homens de negócio praticam um jogo que mescla habilidade e sorte, cujos resultados médios são desconhecidos pelos jogadores. Desse modo, se não fosse da natureza humana arriscar-se, não haveria investimento. $\mathrm{O}$ homem tem satisfação em arriscar a sorte e construir fábricas, estradas, fazendas, etc. É o chamado "animal spirits" que guia as decisões de investimento, dadas as possibilidades técnicas de gerar renda com aquele capital e a taxa de juros.

Assim, na visão keynesiana, as variáveis determinantes do investimento são: a taxa de juros, o retorno esperado do capital (que depende do estado das expectativas) e o custo de reposição dos bens de capital. Ao se observar a evolução de uma economia, deve-se esperar um aumento dos investimentos quando houver uma redução da taxa de juros ou do custo de reposição do bem de capital, ou quando houver um aumento do retorno esperado do investimento. A taxa de juros e o custo de reposição são variáveis observáveis. Contudo, o retorno esperado do capital depende das expectativas dos agentes, o que é subjetivo e não observável de forma direta.

A visão neoclássica se contrapõe à keynesiana, ao abordar o investimento a partir de uma modelagem teórica de acumulação ótima de capital, a qual parte do princípio de maximização do valor presente da empresa. Assumindo que o valor de mercado dos ativos é fixo, a maximização dos lucros descontados resulta na mesma trajetória de acumulação de capital que a maximização do valor presente da firma. As equações (1.1) e (1.2) representam, respectivamente, o valor presente da empresa e o fluxo de lucros descontados:

(1.1) $W=\int_{0}^{\infty} e^{-i t} R(t) d t$ e (1.2) $W^{+}=\int_{0}^{\infty} e^{-i t} P(t) d t$, em que $R(t)$ é o fluxo líquido de receitas, $i$ é a taxa de desconto e $P(t)$ são os lucros líquidos.

O modelo neoclássico da acumulação ótima de capital pode ser derivado da maximização do valor presente da firma, da maximização da integral dos lucros descontados ou 
simplesmente da maximização dos lucros em cada instante de tempo. O modelo completo definido por Jorgenson (1967) consiste num conjunto de equações que definem: a função de produção (1.3), as produtividades marginais de fatores (1.4) e (1.5) e duas outras condições definidas em (1.6) e (1.7).

$$
Y=F(K, N), f^{\prime}>0
$$

$$
\frac{\partial Y}{\partial N}=\frac{w}{p_{Y}} \text { e (1.5) } \frac{\partial Y}{\partial K}=\frac{p_{K}}{p_{Y}}
$$

(1.6) $\quad I=\dot{K}+\delta . K$

(1.7) $\quad p_{K}=q \cdot(i+\delta)-\dot{q}$

em que $Y$ é o nível de produto, $N$ é a quantidade de trabalhadores, $K$ é o estoque de capital, $I$ é o investimento em bens duráveis, $p_{Y}$ é o preço do produto, $w$ é o salário, $q$ é o preço dos bens duráveis (capital), $\delta$ é a taxa de depreciação e $p_{K}$ é o valor do aluguel implícito nos bens de capital (preço sombra). ${ }^{1}$ Assumem-se as premissas usuais sobre a função de produção neoclássica. A combinação dessas condições determina o nível de produto, trabalho e capital ótimos, juntamente com o nível de investimento e do preço sombra dos serviços de capital.

Dessas equações, conforme argumenta Jorgenson (1967), é possível a derivação da função de demanda por capital (1.8). Sob a hipótese de que as firmas seguem uma trajetória ótima de acumulação de capital, o nível inicial de capital é igual à demanda por serviços de capital. O investimento é dado pela condição (1.6), sendo que o nível de serviços de capital inicial é fixo.

$$
K=K\left(p_{K}, w, p_{Y}\right)
$$

Desse modo, para valores fixos de preço do bem produzido e de salários, o preço implícito dos serviços de capital deve permanecer constante. Mantendo o preço dos bens de capital constante, a taxa de mudança dos preços dos bens de capital deve variar na mesma proporção que a taxa de juros, de modo a deixar o preço sombra do capital constante. Mantendo o preço dos bens de investimento constante, essa condição implica que a taxa interna de juros sobre os bens de capital, definida como $i-\dot{q} / q$, não varia em relação à taxa de juros. Para derivar a demanda por investimento como função da taxa de juros, é necessário diferenciar a demanda por serviços de capital com relação ao tempo - equação (1.9):

\footnotetext{
${ }^{1}$ A apresentação do modelo neoclássico segue a notação original do modelo de Jorgenson (1967), com alteração apenas das letras que denotam a taxa de juros e o preço sobra do capital, para evitar confusões com outros conceitos que serão definidos mais adiante. $\mathrm{O}$ ponto em cima das variáveis representa a variação no tempo das variáveis.
} 


$$
\dot{K}=\frac{\partial K}{\partial p_{K}} \cdot \frac{\partial p_{K}}{\partial t}+\frac{\partial K}{\partial w} \cdot \frac{\partial w}{\partial t}+\frac{\partial K}{\partial p} \cdot \frac{\partial p_{Y}}{\partial t}
$$

Diferenciando o preço sombra do capital - equação (1.7)) - com relação ao tempo, chega-se à expressão (1.10):

$$
\frac{\partial p_{K}}{\partial t}=(\delta+i) \cdot \frac{\partial q}{\partial t}+q \cdot \frac{\partial i}{\partial t}-\frac{\partial \dot{q}}{\partial t} .
$$

Substituindo a expressão (1.10) na equação (1.9), e aplicando o resultado na expressão (1.6), obtém-se:

(1.11) $I=\frac{\partial K}{\partial p_{K}} \cdot\left[(\delta+i) \cdot \frac{\partial q}{\partial t}+q \cdot \frac{\partial i}{\partial t}-\frac{\partial \dot{q}}{\partial t}\right]+\frac{\partial K}{\partial w} \cdot \frac{\partial w}{\partial t}+\frac{\partial K}{\partial p} \cdot \frac{\partial p_{Y}}{\partial t}+\delta \cdot K=I\left(w, p_{K}, p_{Y}, \frac{\partial p_{K}}{\partial t}, \frac{\partial w}{\partial t}, \frac{\partial p_{Y}}{\partial t}\right)$.

Assim, a função investimento neoclássica depende da taxa de juros, dos salários, do preço dos bens ofertados e das variações no tempo do valor implícito do preço sombra do capital, dos salários e do preço dos bens. Quanto maior o preço do bem produzido em relação ao salário, maior o volume de investimento. Por outro lado, a expressão (1.11) implica que o investimento cai em razão de um aumento na taxa de juros da economia. ${ }^{2}$

\subsection{O papel do preço dos ativos}

Tobin (1969) apresentou um esquema geral sobre a acumulação de capital que integrou a determinação do investimento na análise monetária, analisando o papel do preço dos ativos sobre a acumulação de capital. A modelagem do autor partiu de um esquema contábil que considerou uma economia formada por $m$ setores de atividades e o governo, os quais geram e se apropriam da riqueza nacional. A riqueza está na forma de $n$ ativos disponíveis na economia. O esquema contábil geral pode ser usado para uma análise monetária assumindo que: (i) cada ativo tem uma taxa de retorno $r_{n},(n=1,2, \ldots N)$ e (ii) cada setor $(j=1,2, \ldots, m)$ tem uma demanda líquida por cada ativo $\left(f_{n j}\right)$, a qual é função do vetor $r_{n}$ e de outras variáveis.

Tobin supôs que cada setor está sujeito à restrição de sua própria riqueza líquida. Os indivíduos escolhem sua cesta de ativos, mas não a sua riqueza líquida, a qual é determinada pela acumulação de ativos passados e pelo preço corrente dos ativos. Conforme o tempo passa, cada indivíduo pode poupar e está sujeito a ganhos ou perdas de capital que vêm da valorização. Para todos os setores, a soma total das respostas dos ativos a mudanças em qualquer taxa de retorno $r_{k}$, por exemplo, é nula e a soma das mudanças nos ativos com

\footnotetext{
${ }^{2}$ Ver Jorgenson (1967) a esse respeito.
} 
relação a mudanças na riqueza é igual a um. Essas propriedades são válidas para a função de demanda agregada dos setores, ou seja, para $f_{n}=\sum_{n=1}^{N} f_{n j}$.

$$
\sum_{n=1}^{N} \frac{\partial f_{n j}}{\partial r_{k}}=0 \text { e } \sum_{n=1}^{N} \frac{\partial f_{n j}}{\partial W_{j}}=1 .
$$

Um exemplo simples de aplicação desse esquema é uma economia com apenas um setor e dois ativos: papel moeda emitido pelo governo para financiar o déficit orçamentário e o capital físico homogêneo. ${ }^{3}$ Nessa modelagem, $p_{Y}$ é o preço dos bens produzidos, $q$ é o preço de mercado dos bens de capital, $r_{M}$ e $r_{K}$ são a taxa de retorno do dinheiro e do capital, $\rho . p_{Y}^{e}$ é a taxa esperada de mudança nos preços das mercadorias, $r_{M}$ ’ é a taxa nominal de juros do dinheiro, $R$ é a eficiência marginal do capital relativa ao custo de reprodução, $W$ é a riqueza - a qual é medida em preços das mercadorias - e $Y$ a renda, também medida em preços das mercadorias. O modelo para capital e moeda é composto pelo sistema de equações (1.12) a (1.16).

(1.12) $\quad W=q . K+M / p_{Y}$

(1.13) $f_{1}\left(r_{K}, r_{M}, Y / W\right) \cdot W=q \cdot K$

(1.14) $f_{2}\left(r_{K}, r_{M}, Y / W\right) \cdot W=M / p_{Y}$

(1.15) $\quad r_{K} \cdot q=R$

(1.16) $r_{M}=r_{M}^{\prime}-\rho \cdot p_{Y}^{e}$

A proporção de cada ativo independe da escala absoluta da riqueza. Uma hipótese adicional é que $f_{1}=1-f_{2}$. Assim, uma das duas equações de equilíbrio pode ser omitida equação (1.13) ou (1.14). Assume-se que as derivadas $\partial f_{1} / \partial r_{k}$ e $\partial f_{2} / \partial r_{M}$ são positivas e as derivadas cruzadas, negativas. A razão, renda-riqueza aparece nas duas funções de demanda. A hipótese convencional diz que, conforme aumenta o nível de renda, mais dinheiro é necessário para as transações. Isso implica que a demanda por capital, mantendo tudo o mais constante, se reduz com o aumento na renda.

\footnotetext{
${ }^{3}$ Tobin (1969) argumentou que o modelo geral pode ser agregado ou desagregado conforme o objetivo do pesquisador e apresentou outras ilustrações de seu modelo geral. $\mathrm{O}$ autor incluiu no presente exemplo o setor governo e os títulos públicos, além do capital físico e da moeda. Nesse caso, havia três equações de equilíbrio e três equações de taxa de retorno. Outro exemplo apresentado por Tobin foi um modelo que incluía depósitos bancários e empréstimos. Todavia, quanto mais setores e ativos são incluídos, maior e mais complexo fica o modelo. Nesse último modelo, o autor apresentou um sistema com onze equações. A hipótese de que o capital físico é homogêneo pode ser eliminada e o capital físico pode ser desagregado em habitação, indústria, equipamentos, bens de consumo duráveis etc.
} 
Tobin (1969) adotou a hipótese keynesiana de que a elasticidade parcial da demanda por dinheiro com relação à renda é positiva, mas não excede a unidade. A equação (1.15) expressa a relação inversa entre o valor de mercado do capital e sua taxa de retorno. O nível de preço das mercadorias não afeta a taxa real de retorno do capital. Por outro lado, a expectativa da taxa de inflação (mercadorias) afeta negativamente a taxa real de retorno do dinheiro.

Omitindo a equação (1.13), o modelo de capital e moeda é constituído por um sistema de quatro equações. Sua interpretação depende de quais variáveis são consideradas endógenas. Tobin (1969) considerou que uma possível interpretação de curto prazo desse modelo é assumir que $r_{K}, r_{M}, W$ e $q$ são variáveis endógenas e $K, M, Y, p_{Y}, R, \rho . p_{Y}^{e}, r_{M}$ ' são variáveis exógenas. Após manipulações algébricas, o modelo pode ser expresso por uma única equação de $q$ :

$$
f_{2}\left(\frac{R}{q}, r_{M}, \frac{Y}{q K+M / p_{Y}}\right) \cdot\left(q K+M / p_{Y}\right)=\frac{M}{p_{Y}} .
$$

As hipóteses assumidas no modelo são suficientes, mas não necessárias, para assegurar que $\partial q / \partial M>0$, ou seja, um aumento da quantidade de dinheiro causa uma valorização do capital já existente e, portanto, estimula o investimento. As mesmas condições asseguram três outras propriedades: (i) que $\partial q / \partial R>0$, ou seja, que um aumento da eficiência marginal do capital valoriza o capital; (ii) que $\partial q / \partial r_{M}<0$, ou ainda, que um aumento da taxa de juros (retorno do ativo monetário) diminui o valor do capital; e (iii) que $\partial q / \partial Y<0$, ou seja, o equilíbrio dos ativos requer uma desvalorização do capital conforme aumenta o nível de renda relativamente ao estoque de ativos.

Assim, a abordagem de Tobin (1969) acrescentou à teoria do investimento a ideia de que a taxa de investimento, que é a variável que mede a velocidade na qual os investidores desejam aumentar seu estoque de capital, está relacionada à valorização do capital - a evolução do seu preço de mercado relativamente ao seu custo de reposição. No artigo de Tobin (1969), a equação (1.17) foi interpretada como uma curva LM, pois ela expressa a combinação de níveis de renda $(Y)$ e de taxa de retorno do capital que são compatíveis com o equilíbrio do mercado de ativos. ${ }^{4}$

Como resposta a ideia de Tobin de que a política monetária pode afetar a valorização dos ativos, e assim influenciar o investimento, a escola neoclássica das expectativas

\footnotetext{
${ }^{4}$ A diferença em relação à curva LM tradicional, é que a taxa de juros do eixo vertical foi substituída pelo retorno do capital. Keynes (1936) havia assumido que as duas taxas são iguais, ou diferem somente pelo prêmio de risco.
} 
racionais formulou uma visão alternativa sobre a relação entre nível de atividades e política monetária. Nessa visão, o aumento do nível de atividades ocorre em razão do simples anúncio de uma expansão monetária, como antecipação de ganhos futuros e de aumentos de riqueza.

Blanchard (1981) apresentou um modelo com expectativas racionais da abordagem IS-LM de Hicks. Nessa visão, os preços são fixos e a oferta de produto é determinada pela demanda agregada de bens e serviços. $\mathrm{O}$ autor assumiu que o comportamento dos mercados de ativo é racional. No modelo de Blanchard (1981) há três ativos: dinheiro, bônus de curto prazo e ações. Os preços das ações são dados, a todo o momento, pelo valor presente descontado dos dividendos futuros. O comportamento dos agentes no mercado de bens e no mercado de ativos permite analisar o equilíbrio de longo prazo do sistema e as respostas do mercado a mudanças esperadas e não esperadas na política econômica.

Seguindo Tobin (1969), o gasto privado dos consumidores e das empresas depende do valor da riqueza dos agentes, o qual equivale à soma de suas ações na bolsa de valores. Quando os preços das ações aumentam, a riqueza dos consumidores aumenta, permitindo que eles elevem seus gastos. Aumentando a demanda por bens, há espaço para as empresas empreenderem novos investimentos. O preço por unidade de capital $(q)$ é igual ao valor unitário do capital na bolsa de valores (índice de preços das ações).

O gasto privado $a(q)$ é uma função crescente da riqueza da bolsa de valores e o gasto público $g$ é exógeno. O comportamento dinâmico do mercado de bens depende da relação existente entre o gasto total e o produto. Se o gasto total se igualar ao produto $(y)$, o mercado está em equilíbrio. Se houver excesso de despesa em relação à produção, há crescimento do produto, e se houver excesso de oferta, decrescimento. A equação (1.18) descreve esse comportamento:

(1.18) $\dot{y}=\alpha[a(q)+g-y]$,

em que o coeficiente $\alpha$ é a taxa de mudança do produto e o termo em colchetes representa o excesso de gasto sobre a produção. A equação (1.18) pode ser representada por um diagrama de fazes. A Figura 1.1 traz a curva $\dot{y}=0$, na qual o mercado de bens está em equilíbrio e o gasto é igual a produção. Quanto maior o q, maior a despesa e o nível de produção necessário para manter o mercado de bens em equilíbrio - por isso, essa curva tem inclinação positiva. Em qualquer ponto acima da curva $\dot{y}=0$, o gasto excede a produção, os estoques diminuem e é necessário aumentar a produção, o que implica que $\dot{y}>0$. Abaixo dessa cur- 
va, o gasto é menor que a produção, os estoques aumentam e é preciso diminuir a produção $(\dot{y}<0)$.

Figura 1.1. Diagrama de fase, equilíbrio de longo prazo

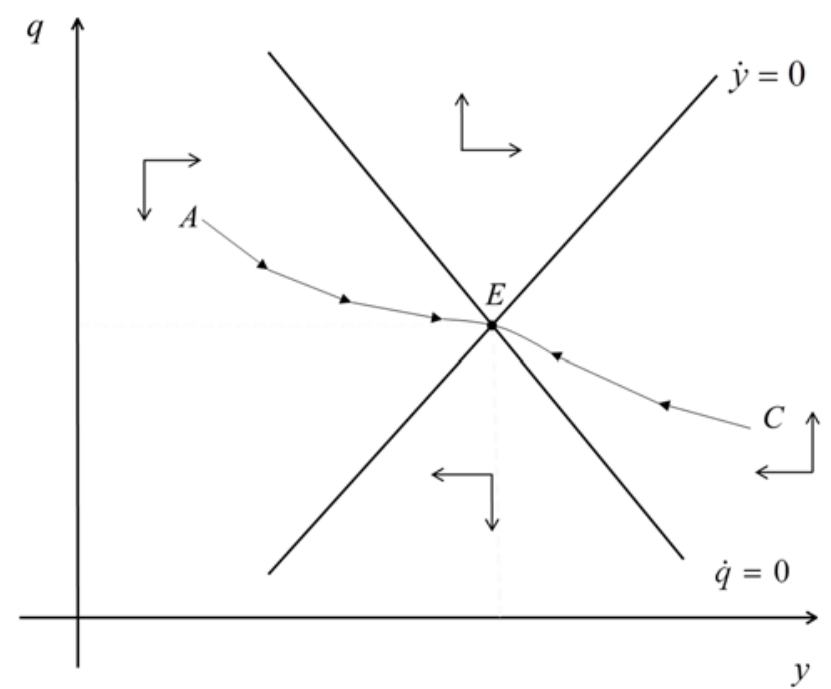

O dinheiro $(M)$ não recebe juros, mas também não tem risco. Os bônus de curto prazo funcionam como poupança e pagam um rendimento $i$, a taxa de juros da economia. $\mathrm{O}$ rendimento esperado das ações é composto por duas partes: (i) os fluxos esperados de dividendos que serão pagos no futuro $(\pi)$ e (ii) os ganhos ou perdas esperados de capital $\dot{q}^{\varepsilon}$. A taxa de rendimento esperado das ações $r^{\varepsilon}$ é definida pela expressão (1.19).

(1.19) $r^{\varepsilon}=\frac{\pi}{q}+\frac{\dot{q}^{\varepsilon}}{q}$.

Blanchard (1981) assume que os acionistas preveem de forma perfeita os ganhos e perdas de capital - hipótese de previsão perfeita -, exceto em condições em que as autoridades monetárias anunciam uma mudança de política. Essa premissa é equivalente à hipótese de expectativas racionais: os ganhos de capital se igualam aos ganhos esperados de capital conforme indica a equação (1.20).

(1.20) $\frac{\dot{q}}{q}=\frac{\dot{q}^{\varepsilon}}{q}$.

A demanda por moeda é uma função crescente da renda e decrescente da taxa de juros. Dessa forma, a taxa de juros (i) pode ser definida de acordo com a equação (1.21), em que z e h são parâmetros positivos do modelo e M é a quantidade de moeda.

(1.21) $\quad i=z . y-h . M$. 
Blanchard (1981) assume, ainda, que os bônus e as ações são substitutos perfeitos na carteira de valores dos investidores. Assim, pela regra de arbitragem, os dois ativos devem ter o retorno: $r^{\varepsilon}=i$. Definindo os fluxos esperados de dividendos como uma função linear e crescente da renda $\left(\pi=\alpha_{0}+\alpha_{1} \cdot y\right)$, e substituindo as equações (1.21) e (1.19) na condição de arbitragem, obtém-se a equação dinâmica do mercado de ativos.

$$
\left.z . y-h \cdot M=\frac{\alpha_{0}+\alpha_{1} \cdot y}{q}+\frac{\dot{q}}{q} \text { ou } \dot{q}=q \cdot z \cdot y-h \cdot M\right]-\left(\alpha_{0}+\alpha_{1} \cdot y\right)
$$

Dessa expressão se deriva a curva $\dot{q}=0$ da Figura 1.1, a qual traz combinações de $y$ e $q$ para as quais não há ganhos nem perdas de capital e a taxa de juros para pelos bônus é igual aos benefícios das ações: $i=\pi / q$. Acima da curva $\dot{q}=0$, a taxa de juros deve ser maior que os dividendos das ações, para manter o equilíbrio do mercado de ativos Assim, o preço das ações deve subir $(\dot{q}>0)$. Abaixo da curva, por outro lado, os benefícios das ações devem ser maiores que a taxa de juros, e os investidores devem esperar perdas de capital para manter o equilíbrio do mercado $(\dot{q}<0)$.

A intercepção das duas curvas representa o equilíbrio de longo prazo do modelo (ponto $E$ ). $\mathrm{O}$ diagrama de fase apresenta instabilidade de sela. Há apenas a curva $A C$, que apresenta convergência para o equilíbrio. Para cada valor de produção, há somente um preço de ação que traz o sistema de volta à sua posição de equilíbrio. Esse preço de ação corresponde ao valor de $q$ ao longo da curva $A C$.

Nessa modelagem, quando aumenta o estoque de moeda, a curva $\dot{q}=0$ se desloca para cima e surge uma nova linha estável $A C$ acima da que existia para o equilíbrio inicial. Como a produção se ajusta lentamente, deve ocorrer inicialmente excesso de despesa sobre produção, o que faz os preços das ações subirem. Depois, conforme aumenta a produção, os preços das ações caem até alcançar o novo equilíbrio com preço de ação e nível de produto maiores. Isso indica que, quando um aumento da oferta monetária é anunciado, os agentes econômicos sabem que isso significará maior renda, maiores ganhos e menores taxas de juros no futuro. Por isso, o valor das ações se eleva, refletindo o valor presente mais alto do fluxo esperado de dividendos. O aumento dos preços das ações, por sua vez, estimula o consumo, o qual leva a um aumento da produção antes mesmo que o estoque de moeda se eleve.

A modelagem proposta por Blanchard (1981) ajudou a explicar, do ponto de vista neoclássico, a relação entre nível de atividades e política monetária. $\mathrm{O}$ aumento do nível de 
atividades frente a uma política monetária ocorre em razão da antecipação de ganhos futuros e das expectativas de aumentos de riqueza. A análise teve um papel ativo no debate sobre os efeitos da política monetária. Posta numa visão de aquisição de bens de capital, essas ideias serviram também ao desenvolvimento de uma análise dinâmica de equilíbrio parcial do investimento.

Essa aplicação é apresentada em Sheffrin (1985) e tem por referência o investimento habitacional num mercado de serviços de moradias ocupadas por inquilinos ou por seus proprietários. A renda anual desse mercado deve se igualar ao custo associado à compra da casa no início do ano e sua venda ao final de um ano. Esse custo depende do preço da casa $(q)$; da taxa de depreciação $(\delta)$; do imposto sobre a renda $(\phi)$, da taxa de juros $(i)$; do imposto sobre a propriedade $(\mu)$; da taxa de inflação $\left(\dot{p}_{Y} / p_{Y}\right)$; e da taxa de valorização real da moradia $\dot{q} / q$. O aluguel é dado pela equação (1.23) e a variação de preços ( $\dot{q})$ é dada pela expressão (1.24).

$$
\begin{aligned}
& R_{H}=q \cdot\left[\delta+(1-\phi) \cdot(i+\mu)-\dot{p}_{Y} / p_{Y}-\dot{q} / q\right] \\
& \dot{q}=-R_{H}-q \cdot\left[\delta+(1-\phi) \cdot(i+\mu)-\dot{p}_{Y} / p_{Y}\right]
\end{aligned}
$$

A premissa de previsão perfeita (expectativa racional) assume que a variação de preço esperada nesse mercado seja igual à variação observada de preços, aos moldes do que foi assumido no modelo de Blanchard (1981). O investimento é dado pela expressão (1.25), em que a mudança no estoque de moradias $(H)$ é igual ao excesso de investimento imobiliário $\left(I_{H}\right)$ sobre a depreciação $(\delta . H)$. O investimento, por sua vez, é uma função crescente do preço dos imóveis.

$$
\dot{H}=I_{H}(q)-\delta \cdot H
$$

Com base nas equações (1.24) e (1.25) é possível construir um diagrama de fases semelhante ao apresentado na Figura 1.1. O eixo horizontal passa a designar o estoque de moradias e a curva $\dot{y}=0$ passa a expressar curva $\dot{H}=0$. O sistema também apresenta instabilidade de sela, havendo apenas a linha AC na qual o mercado converge para o equilíbrio (ponto $E$ ).

Nesse modelo, taxa de juros, inflação e impostos (sobre a renda e sobre a propriedade) interferem no equilíbrio de mercado. Sheffrin (1985) expõe o caso de um aumento na taxa de inflação esperada, que desloca a curva $\dot{q}=0$ para cima, fazendo com que o preço 
das moradias se eleve. Essa valorização imobiliária estimula o investimento e, gradativamente, novas unidades habitacionais são incorporadas ao mercado.

\subsection{A influência do crédito no investimento}

As teorias discutidas nas seções anteriores partem do pressuposto implícito de que o mercado de crédito é perfeito. Nessa condição, um aumento do valor de mercado do capital (ações, preços dos imóveis etc.) estimularia os agentes a investir na produção de novas unidades de capital numa dada proporção do aumento do preço do capital em relação à taxa de juros. Nesse sentido, a reação é automática e não passa por um mercado de crédito propriamente dito. $\mathrm{O}$ mercado de crédito é o local onde se dá a intermediação financeira e envolve interesses de poupadores, tomadores de empréstimo e bancos.

Stiglitz e Weiss (1981) se contrapõe à visão de que o mercado de crédito é perfeito e que a taxa de juros se ajusta para equilibrar a oferta e a demanda de crédito, ou seja, para balancear os interesses de poupadores e tomadores de empréstimo. De acordo com os autores, o mercado de capitais tem informação imperfeita, ou seja, os bancos não são capazes de controlar diretamente as ações de todos os tomadores de empréstimo. Nesse caso, as instituições de intermediação financeira utilizam a taxa de juros e o colateral como mecanismos de proteção para reduzir o risco de inadimplência das dívidas. Os autores argumentam que, no equilíbrio, pode haver racionamento de crédito, o que implica excesso de demanda em relação à oferta de fundos.

Segundo os autores, a taxa de juros e o risco do empréstimo interagem no processo de concessão de crédito pelos bancos. A taxa de juros afeta o risco dos financiamentos de duas formas: (i) ela interfere na escolha de potenciais tomadores de empréstimos - efeito de seleção adversa; e (ii) ela influencia a ação dos tomadores de empréstimos - efeito de incentivo. Ambos os efeitos são derivados diretamente da existência de informações imperfeitas nesses mercados.

A seleção adversa é uma consequência das diferentes probabilidades dos emprestadores pagarem suas dívidas. A expectativa de retorno dos bancos depende dessa probabilidade de pagamento. Dessa maneira, os bancos procuram identificar os tomadores de empréstimos com maiores probabilidades de pagamento e, para isso, eles utilizam vários mecanismos de seleção. Os principais mecanismos de seleção são a taxa de juros e o requerimento de colaterais (garantias).

A taxa de juros como mecanismo de seleção atua de forma particular. Os indivíduos com disposição para pagar uma taxa de juros maior, em geral, são amantes do risco e sua 
probabilidade de pagar é menor. Com o aumento da taxa de juros, o risco de não pagamento aumenta e os lucros do banco caem. Da mesma forma, o aumento da taxa de juros ou mudanças nos termos do contrato de crédito podem afetar o comportamento do investidor. $\mathrm{O}$ aumento da taxa de juros diminui o retorno do investimento para o empreendedor e, portanto, diminui a possibilidade de sucesso do projeto. Altas taxas de juros induzem as empresas a executarem projetos arriscados, cujos ganhos potenciais são maiores para compensar um custo de capital também mais elevado, mas cujas probabilidades de sucesso são menores.

Por essas razões, o retorno esperado dos bancos aumenta menos que a taxa de juros, ou seja, ele cresce a taxas decrescentes. A partir de certo ponto, o retorno esperado pode cair, mesmo com o aumento dos juros. Esse processo pode ser observado no quadrante $\Pi$ por $i$ da Figura 1.2, em que $\Pi$ é o retorno esperado dos bancos, $i$ é a taxa de juros e $i^{*}$ é a taxa que maximiza o retorno dos bancos. Como os bancos são maximizadores de lucro, eles não devem financiar projetos a uma taxa de juros superior ao valor $i^{*}$, dado que tal empréstimo teria, por causa do alto risco, um retorno inferior ao da média dos financiamentos.

Figura 1.2 Oferta de crédito e retorno esperado dos bancos

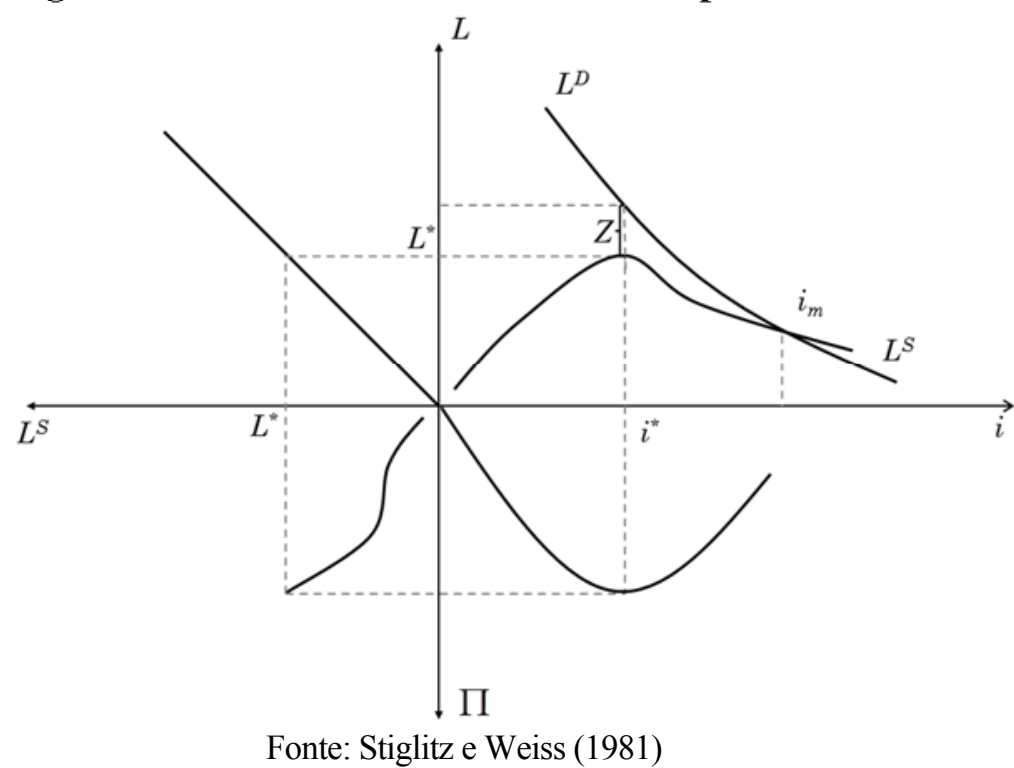

A oferta de crédito é determinada pelo retorno esperado dos bancos: quanto maior o retorno, maior a oferta de crédito. Mas, essa oferta cresce a taxas decrescentes, até a taxa $i^{*}$. A partir desse ponto não há mais oferta de crédito, porque deixa de ser vantajoso para os bancos emprestar recursos. A relação entre oferta de crédito e retorno dos bancos está ilustrada no quadrante $L^{S}$ por $\Pi$ da Figura 1.2, em que $L^{S}$ denota o volume de crédito ofertado. Observa-se que a taxa de juros que maximiza o retorno esperado pelos bancos determina o ponto final da oferta de crédito. O quadrante $L$ por $i$ traz as relações de oferta e de deman- 
da por crédito. Observa-se que a oferta de crédito é crescente com relação à taxa de juros até o ponto em que o retorno esperado dos bancos é maximizado. A partir dele, a oferta cai conforme aumenta a taxa de juros. A demanda por crédito aparece como uma relação negativa entre juros e quantidade desejada de crédito.

As análises tradicionais argumentam que na presença de um excesso de demanda por crédito, os tomadores de empréstimos iriam oferecer uma taxa de juros mais alta para os bancos até o ponto em que a demanda se igualasse com a oferta. Mas, uma taxa de juros maior que $i *$ levaria a uma queda do retorno esperado dos bancos. Dessa forma, os bancos não aceitariam a proposta de crédito e o excesso de demanda perduraria. Não há, portanto, força competitiva que levasse a oferta a se igualar com a demanda por crédito no ponto de máximo retorno do empréstimo para os bancos. Em outros termos, há racionamento de crédito no mercado e esse racionamento pode ser permanente. O excesso de demanda por crédito, denotado por $Z$ na Figura 1.2, mostra que os investidores estão dispostos a pagar uma taxa de juros maior - aquela que equilibra a oferta e a demanda $\left(i_{m}\right)$ - mas os bancos não atendem aos pedidos de crédito. Os bancos emprestam o montante $L^{*}$ à taxa $i^{*}$.

Para explicar o funcionamento da demanda por crédito, Stiglitz e Weiss (1981) assumem as seguintes premissas: (i) não há retornos crescentes de escala de produção; (ii) todos os indivíduos têm a mesma função utilidade $U(W), U^{\prime}>0, U^{\prime \prime}<0$, em que $W$ é a riqueza dos indivíduos; (iii) todo tomador de empréstimo é avesso ao risco; (iv) os indivíduos têm níveis diferentes de riqueza inicial, $W_{0}$; (v) cada empresário tem um conjunto de projetos que pode desenvolver; (vi) cada projeto tem uma probabilidade de sucesso $p(R)$, em que $R$ é o retorno se bem-sucedido (se não for bem-sucedido o retorno é zero); (vii) a probabilidade de sucesso é negativamente relacionada ao retorno do projeto, $p^{\prime}(R)<0$; (viii) cada indivíduo tem uma alternativa de investimento seguro (com taxa de retorno i); (ix) os bancos não observam ao mesmo tempo a riqueza dos tomadores de crédito e os projetos por eles desenvolvidos; e (x) os bancos oferecem o mesmo contrato, definido pela taxa de juros e pelo colateral, para todos os tomadores de empréstimos. O contrato funciona para os bancos como um mecanismo de seleção.

A decisão de tomar crédito para desenvolver um projeto vem da comparação feita pelo investidor das utilidades esperadas associadas a três situações distintas: (a) investimento sem risco (investimento seguro); (b) a tomada de empréstimo para execução do projeto; ou (c) o autofinanciamento do empreendimento. A utilidade esperada do investimento seguro depende positivamente do valor da riqueza inicial e da taxa de retorno do investimento seguro, de acordo com a equação (1.26). 
(1.26) $U\left(W_{0} . i\right)$, sendo que $\frac{d U\left(W_{0} . i\right)}{d W_{0}}=U^{\prime} . i$.

No autofinanciamento (situação c), a utilidade esperada é definida de acordo com a expressão (1.27), em que $W_{0} \geq 1$. No caso em que o indivíduo toma emprestado para desenvolver o projeto (situação b), a utilidade esperada é dada pela expressão (1.28), em que $\hat{i}$ é a taxa de juros do financiamento. As derivadas da função utilidade com subscrito 1 das equações (1.27) e (1.28) referem-se à situação em que o projeto é bem-sucedido e o contrato é pago. As derivadas com subscrito 2, referem-se à situação de insucesso, ou seja, com inadimplência.

$$
\begin{aligned}
& U_{A}\left(W_{0}\right) \equiv \max _{R}\left\{U\left(\left(W_{0}-1\right) \cdot i+R\right) \cdot p+U\left(\left(W_{0}-1\right) \cdot i\right) \cdot(1-p)\right\}, \frac{d U_{A}\left(W_{0}\right)}{d W_{0}}=\left[U_{1}^{\prime} \cdot p+U_{2}^{\prime} \cdot(1-p)\right] \cdot i \\
& U_{B}\left(W_{0}\right) \equiv \max _{R}\left\{U\left(W_{0} \cdot i-(1+\hat{i})+R\right) \cdot p+U\left(\left(W_{0}-1\right) \cdot i\right) \cdot(1-p)\right\}, \frac{d U_{B}\left(W_{0}\right)}{d W_{0}}=\left[U_{1}^{\prime} \cdot p+U_{2}^{\prime} \cdot(1-p)\right] \cdot i
\end{aligned}
$$

As primeiras derivadas de cada função em relação à $W_{0}$ ajudam a identificar dois grupos de indivíduos: (i) os que demandam crédito e (ii) os que estão credenciados a obter o empréstimo. De acordo com as hipóteses assumidas, as três derivadas são positivas. Assumindo que o colateral requerido pelo banco tenha valor menor que o valor do investimento, tem-se que a derivada $U^{\prime}$ ' da curva de empréstimo - equação (1.28) - é menor que a derivada $U_{2}^{\prime}$ da curva de autofinanciamento - equação (1.27). Isso significa que as utilidades esperadas do autofinanciamento e do empréstimo crescem com relação ao nível inicial de riqueza, mas a sensibilidade do autofinaciamento é maior que a do empréstimo. Essa ideia é ilustrada na Figura 1.3, em que a curva de autofinanciamento é mais inclinada que a de empréstimo.

Assume-se que a aversão ao risco é decrescente, o que leva a derivada da curva de utilidade esperada do investimento seguro com relação a $W_{0}$ ser menor que a derivada da curva de utilidade esperada do autofinanciamento com relação a $W_{0}$. Em termos gráficos, a curva de investimento seguro tem a menor das três inclinações. Assumindo que existe $\widetilde{W}_{0}>0$, tal que $U_{A}\left(\widetilde{W}_{0}\right)=U\left(\widetilde{W}_{0} . i\right)$, então a curva de autofinanciamento tem necessariamente intercepto menor que o da curva de investimento seguro.

Os bancos só emprestam aos indivíduos cuja riqueza inicial é maior que o colateral requerido. Além disso, para as famílias só é interessante tomar empréstimo quando a utilidade esperada dessa opção for maior que as demais opções (investimento seguro e autofinanciamento). Esse ponto é representado na figura como a interseção das curvas de emprés- 
timo com a de investimento seguro - ponto $E_{1}$, associado ao nível inicial de riqueza $\hat{W}_{0}$. Pode-se dizer que há um nível de riqueza abaixo do qual os indivíduos não têm acesso ao crédito ou não se interessam por ele. $\mathrm{O}$ requerimento de colateral, como uma garantia do empréstimo, atua como um mecanismo de escolha para o banco, na medida em que o banco discrimina os possíveis tomadores de empréstimo pelo nível de colateral que possuem.

\section{Figura 1.3. Colateral como um mecanismo de escolha}

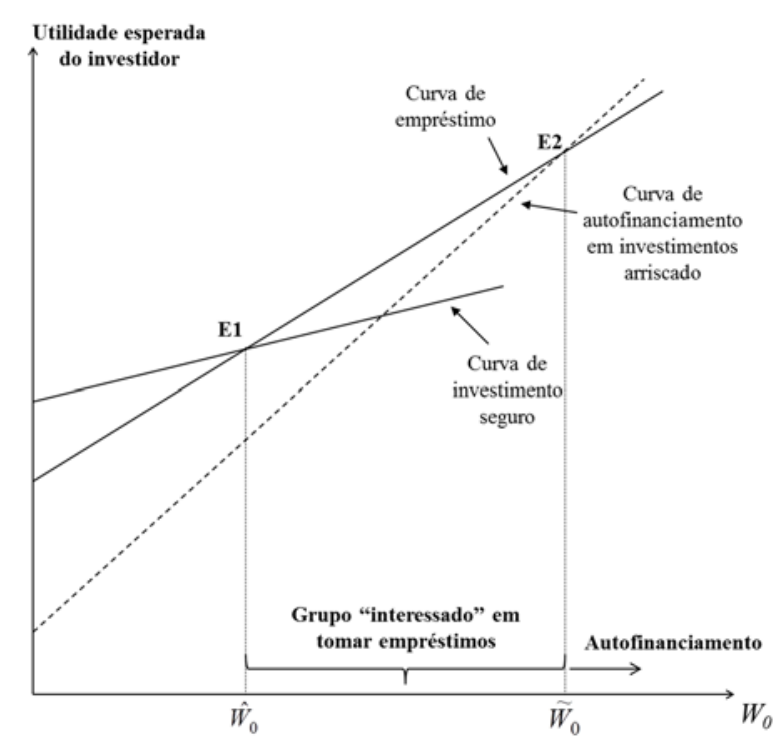

Fonte: Stiglitz e Weiss (1981).

De outro lado, acima do nível de riqueza $\widetilde{W}_{0}$ os indivíduos não têm interesse de tomar recursos emprestados, porque a utilidade esperada do empreendimento autofinanciado é maior que a associada ao projeto com empréstimo. Assim, o grupo habilitado a demandar crédito bancários é aquele formado pelos indivíduos com riqueza inicial entre $\hat{W}_{0}$ e $\widetilde{W}_{0}$.

Nessa visão de mercado financeiro, em que os bancos fazem a intermediação entre poupança e investimento e seu retorno é afetado pelo risco de inadimplência dos investidores, há outra variável relevante para explicar o investimento: a oferta de crédito. Essa variável não se ajusta de maneira automática a mudanças na taxa de juros básica da economia, que remunera o investimento seguro. Um aumento da taxa básica de juros, por exemplo, elevaria a inclinação da curva de investimento seguro, aumentando o tamanho do grupo de investidores que não tem acesso ao crédito ou interesse por ele. Isso reduziria a demanda por crédito, mas a oferta não se alteraria necessariamente, pois um repasse do aumento para as taxas de financiamento dos empréstimos com risco poderia reduzir a qualidade dos projetos e atrair investidores de maior risco, reduzindo o retorno esperado dos bancos. 


\section{Capítulo 2}

\section{Mudança institucional, acumulação de capital e crescimento}

A discussão levada a cabo no primeiro capítulo identificou um conjunto de variáveis que influencia a determinação do investimento agregado de uma economia. O retorno do capital afeta positivamente o investimento, ao passo que a taxa de juros do crédito tem impacto negativo sobre a formação de capital. A evolução dos preços dos ativos, que pode variar conforme o custo de reposição do capital ou as expectativas de retorno, também tem efeito sobre a acumulação de capital, como analisado nos modelos da seção 1.2 do Capítulo 1. Por fim, o capítulo anterior analisou o efeito do comportamento dos bancos num mercado com informação assimétrica, onde a oferta de crédito é restrita e não responde automaticamente aos movimentos de juros e da demanda por crédito.

Esse conjunto de variáveis é bastante relevante para explicar o comportamento do investimento, mas não é suficiente para uma interpretação extensa do fenômeno em economias reais. Por exemplo, a visão de que o retorno do capital afeta o investimento é bastante clara e não há controvérsia na literatura, mas as visões teóricas analisadas no capítulo anterior partem da pressuposição de que os retornos do capital de diferentes economias são determinados tão-somente pelas produtividades marginais do capital, as quais são dadas pelas condições tecnológicas e pelas disponibilidades de fatores. Desconsidera-se a possibilidade de ineficiências e a existência de custos que venham a interferir na remuneração dos fatores e, assim, provocar mudanças no investimento.

De outro lado, tem-se a definição de um mercado de crédito onde os bancos maximizam seus lucros e empregam a taxa de juros e a exigência de colateral para selecionar projetos de investimento, sem considerar que a recuperação do colateral pode ter custos distintos em diferentes sociedades e que o risco de inadimplência, o qual é determinado pelas condições de mercado, por fatores aleatórios e pelo comportamento dos tomadores de empréstimo, é delineado por regras que variam muito entre países e ao longo do tempo.

Neste capítulo é desenvolvido um modelo que incorpora alguns elementos das teorias institucionais entre os fatores determinantes do investimento. A ideia principal é incorporar as instituições como fatores que influenciam o retorno do capital dos empreendedores e dos credores de uma economia. Ao interferir no retorno do capital dos empreendimentos, as instituições - e, portanto, as mudanças institucionais - têm efeito sobre a acumulação de capital. Ao afetar o retorno dos bancos, as instituições interferem no equilíbrio do mercado 
de crédito, possibilitando o surgimento de diferentes níveis de oferta de fundos para as mesmas condições macroeconômicas. A modelagem proposta neste capítulo também analisa o papel dos subsídios ao investimento, os quais podem ter efeitos sobre a oferta de crédito e a disposição de investir, como argumentado por Magnabosco (2011) e Freitas, Magnabosco e Cunha (2013). ${ }^{5}$

A seção 2.1 apresenta os principais elementos das teorias institucionais que fundamentam a visão de que as mudanças institucionais afetam o retorno dos empreendedores e dos credores numa economia. A seção 2.2 desenvolve um modelo em que as condições institucionais afetam o risco de inadimplência e os custos de recuperação de colaterais, com efeitos sobre a oferta de crédito e a taxa de juros do financiamento. Esses resultados são acrescentados no modelo dinâmico de investimento apresentado na seção seguinte. Nessa análise, além da influência das instituições sobre o retorno dos bancos, é acrescentada uma modelagem que considera as ineficiências geradas pelos custos de transação impostos aos empreendedores. Esse esforço resulta num modelo em que as mudanças institucionais afetam a acumulação de capital e o crescimento econômico.

\subsection{A visão teórica do papel das mudanças institucionais}

A visão da Economia Institucional é uma referência útil para aproximar as questões teóricas do crédito e do investimento da análise histórica. North (1990) define as instituições como as regras do jogo na sociedade, as restrições que formam a interação humana. As instituições estruturam os incentivos para as trocas, seja no campo político, econômico ou social. Nesse arcabouço, a mudança institucional define o modo como a sociedade evolui ao longo do tempo e, portanto, é a chave para entender a mudança histórica.

As instituições visam a reduzir a incerteza por meio do estabelecimento de uma estrutura para a interação humana. A estabilidade das instituições reforça a 'certeza', mas elas estão em constante mutação. Como convenções, códigos de condutas, normas, leis e contratos entre indivíduos, as instituições estão em evolução e, dessa forma, alteram continuamente o conjunto de escolhas disponíveis para os indivíduos.

A mudança institucional é um processo que pode resultar de mudanças marginais nas regras, nas restrições informais ou na forma de aplicação da lei (enforcement). ${ }^{6}$ Esse

\footnotetext{
${ }^{5}$ Os subsídios referem-se a uma redução da taxa de juros, a um aporte de recursos governamentais não onerosos que diminui o valor financiado ou a uma redução de tributos sobre bens de capital. Os subsídios são bastante comuns nos setores de infraestrutura e habitação. Também são utilizados amplamente na compra de máquinas e equipamentos e nos setores de pesquisa e desenvolvimento.

${ }^{6}$ Embora as regras formais possam ser mudadas "da noite para o dia" como resultado de uma decisão política ou judicial, as restrições informais incorporadas nos costumes, tradições e códigos de condutas são muito mais difíceis
} 
processo, segundo North (1990), se dá pela interação entre organizações e instituições, ou seja, entre grupos de indivíduos unidos em algum propósito comum e as regras que conduzem seu comportamento. Estão incluídos os agentes políticos (partidos políticos, congressos, agências regulatórias etc.), os agentes econômicos (empresas, uniões empresariais, famílias, cooperativas etc.), os agentes sociais (igrejas, clubes, associações atléticas etc.) e os agentes educacionais (escolas, universidades etc.).

As instituições, ao lado das tradicionais restrições (orçamentária, tecnológica etc.), determinam as oportunidades na sociedade. As organizações são criadas para aproveitar essas oportunidades e maximizar os objetivos dos grupos que sustentaram sua criação. Ao perceber seu papel e potencial, as organizações se tornam mais eficientes e gradualmente atuam para alterar o arcabouço institucional a seu favor. A mudança ocorre quando o agente individual responde aos incentivos embutidos no próprio arcabouço institucional. $\mathrm{O}$ caminho da mudança institucional, portanto, é formado por essa interação que evolui devido às estruturas de incentivos providas pelas próprias instituições, e pelo processo de retorno no qual os indivíduos percebem e reagem a mudanças no conjunto de oportunidades.

Mudanças incrementais vêm da percepção das organizações políticas e econômicas de que é possível chegar a melhores resultados se o arcabouço institucional existente for alterado, mesmo que marginalmente. Mas essa percepção depende das informações que os agentes recebem e do modo como eles processam essas informações. Se os mercados econômicos e políticos fossem eficientes - ou seja, se não houvesse custos de transação - as escolhas seriam ótimas. Contudo, os agentes, em geral, atuam com informação incompleta e processam essa informação de acordo com habilidades limitadas. Os resultados podem ser, nesse contexto, trajetórias persistentemente ineficientes.

O modo como o conhecimento se desenvolve influencia a percepção que as pessoas têm sobre o mundo que está a sua volta, e o modo como elas explicam e justificam esse mundo influencia os custos de transação. Se os indivíduos percebem que o sistema de regras é claro, os custos são baixos; se eles percebem que o sistema é injusto, o custo aumenta. Além disso, os incentivos construídos no arcabouço institucional são fundamentais na formação do conhecimento. ${ }^{7}$

\footnotetext{
de serem mudadas rapidamente. Essas restrições culturais conectam o passado com o presente e o futuro e representam a chave para explicar a trajetória de mudança histórica.

${ }^{7} \mathrm{O}$ arcabouço institucional forma a direção da aquisição de qualificação e de conhecimento, e essa direção, é o fator decisivo para o desenvolvimento de longo prazo da sociedade. Se uma empresa ou organização investe em conhecimento, o resultado será o aumento da produtividade do capital físico ou humano, que leva ao crescimento da economia.
} 
Na visão de North (1990), há duas fontes de mudança institucional que são: (i) a mudança nos preços relativos e (ii) a mudança nas preferências. Essas mudanças alteram os incentivos individuais para a interação humana. Mudança nos preços de fatores de produção, alteração do custo de aquisição de informação e progresso tecnológico são alguns exemplos de processos que levam ao realinhamento de preços relativos e, consequentemente, induzem mudanças institucionais. Em geral, essas mudanças são endógenas, refletidas pelos esforços de maximização dos agentes.

As organizações maximizam seus objetivos e usam o conhecimento e as informações disponíveis para atingir esses objetivos. Nesse processo, elas também formam conhecimento novo. Ao perceber uma mudança nos preços relativos, ou uma mudança nas preferências, os agentes usam seu poder de barganha para mudar as normas ou refazer contratos de modo a continuar maximizando seus objetivos. Ou seja, a mudança nos preços relativos, ou nas preferências, altera a forma da interação humana. Esse processo consiste em uma mudança marginal nas regras e normas. As instituições recém criadas definem as novas regras do jogo e há o estabelecimento de um novo patamar de custo de transação e de preços relativos. Vale notar, as novas instituições também influenciam o poder de barganha das organizações e as preferências dos agentes, fatores necessários para continuar o processo gradual e contínuo de mudança institucional.

Por fim, é importante destacar que uma mesma mudança nos preços relativos pode afetar de maneiras distintas a economia. Isso ocorre porque em cada sociedade, a mudança resulta em uma adaptação marginal nas regras. A extensão da mudança institucional será determinada pelo poder de barganha relativo dos participantes. Como os poderes de barganha dos grupos são distintos, o ajuste marginal será diferente em cada sociedade. Além disso, sociedades com passados diferentes terão modelos subjetivos distintos e, portanto, farão escolhas políticas diferentes. Assim, mudanças nos preços relativos levarão a resultados divergentes em sociedades com diferentes arranjos institucionais e trajetórias históricas distintas.

As instituições são determinantes dos resultados econômicos de longo prazo porque influenciam o comportamento dos agentes por meio dos custos de transação. Uma variação dos custos de transação afeta o comportamento dos agentes econômicos, a qual influencia o desempenho da economia. Assim, o custo de transação é a ponte entre instituições e desempenho econômico.

Os custos de transação refletem o fato de a informação ser custosa e assimetricamente distribuída entre os agentes. Além disso, a própria forma utilizada para desenvolver 
as instituições que estruturaram a interação humana leva a imperfeições do mercado. Isso ocorre porque são os agentes políticos que especificam e determinam os direitos de propriedade na economia. As características do mercado político são, nesse sentido, a chave essencial para entender as imperfeições de mercado. Os agentes políticos têm o poder de diminuir os custos de transação, o que pode ser feito por meio de legislação ou decreto. Uma queda dos custos de transação aumenta a renda agregada da economia por meio de um processo em que o ganho dos beneficiados compensa a perda dos demais, de forma que conjuntamente esta se torne uma transação vantajosa.

Histórias de sucesso de desenvolvimento econômico envolvem nações com sucessivas inovações institucionais que diminuem os custos de transação e permitem capturar os ganhos de comércio e o potencial de expansão dos mercados. Mas, essas inovações não criam necessariamente as condições de eficiência dos mercados. Ao contrário, elas podem determinar uma trajetória de aumento da ineficiência, caso o poder de barganha dos grupos que ganham com isso seja maior que o do resto da sociedade.

A abordagem de North e Weingast (1989), a qual foi desenvolvida para analisar os efeitos da Revolução Gloriosa na Inglaterra em 1688, segue essa linha: ela ressalta que as mudanças institucionais ocorridas na época buscaram assegurar os interesses dos "vencedores", aumentando as garantias ao direito de propriedade e o grau de proteção à riqueza e reduzindo o poder confiscatório do governo. Essas mudanças deram credibilidade aos governos e tiveram efeitos positivos nos mercados de capitais.

Os princípios de Economia Institucional são amplamente empregados na análise de contratos. Hart e Moore (1989), Aghion e Bolton (1992) e Hart (1995), por exemplo, discute as teorias da firma, dos contratos incompletos, dos custos de transação e do direito de propriedade no âmbito das estruturas de financiamento. O modelo de Hart e Moore (1989), também apresentado em Hart (1995), discute um aspecto chave dos contratos de financiamento: a mudança de controle que ocorre em caso de inadimplência do tomador de crédito. Se a dívida for paga, o empreendedor mantém o controle do projeto, caso contrário, o controle vai para quem emprestou. Nessa abordagem, o empreendedor pode desviar a renda do projeto, ou seja, ele pode ser um agente oportunista. Essa premissa altera de maneira expressiva os resultados de equilíbrio do contrato.

O modelo de Hart e Moore (1989) serve para explicar porque, em geral, os empréstimos de longo prazo são usados para financiar a aquisição de bens de capital e porque, entre esses contratos, aqueles com prazos mais longos são os de financiamento de bens imóveis - real estate. Os empréstimos de curto prazo são usados, em geral, para capital de giro. 
Mas a principal conclusão que se obtém dessa modelagem é a visão de que há diferentes contratos com balanceamentos distintos da repartição de ganhos e perdas entre credores e devedores. Na existência de agentes oportunistas, a análise de Hart (1995) mostra que contratos que privilegiam os empreendedores oportunistas podem coexistir com contratos que asseguram o retorno aos credores. É importante notar que a distribuição dos resultados e perdas não depende exclusivamente da atribuição dos direitos de propriedade, algo que define o contrato em seu princípio básico. O poder de barganha e a forma de contratação são essenciais para a determinação dessa distribuição dos resultados e perdas. Obviamente, numa economia em que prevalecem, por força de lei ou hábito, contratos que privilegiam o empreendedor oportunista, a experiência de prejuízo dos credores irá provocar desconfiança e a redução da disposição a emprestar.

Stasavage (2002) analisou o efeito de políticas institucionais no investimento privado em economias em desenvolvimento. Seu trabalho partiu de uma premissa um pouco distinta da utilizada por North e Weingast (1989), para quem as instituições políticas caracterizadas por sistemas de regulação entre poderes (executivo, legislativo e judiciário) limitam a ação oportunista e autoritária e dão credibilidade ao governo, com efeitos sobre os mercados. ${ }^{8}$ Para Stasavage (2002), nações sem sistemas de regulação entre poderes podem estabelecer sua credibilidade por meio de um mecanismo simples: o convencimento do mercado de que não há risco de ação oportunista dos governantes simplesmente porque os grupos de poder que suportam a classe política seriam prejudicados.

\subsection{Instituições, retorno dos bancos e a oferta de crédito}

As ideias discutidas na seção anterior servem de base para a formulação de um modelo de contrato de financiamento de longo prazo de bens de capital em que o arcabouço institucional pode gerar diferentes distribuições de resultados para credores e tomadores de crédito, com influência sobre o volume de crédito ofertado. Nessa modelagem, as restrições formais e informais para controlar o comportamento oportunista dos agentes afetam a probabilidade de adimplência dos contratos e os custos de recuperação das garantias reais das dívidas financeiras.

O financiamento de um projeto de investimento é um contrato que envolve cinco elementos: o montante de empréstimo $(B)$, a taxa de juros do financiamento $\left(i^{*}\right)$, o colateral que é um ativo usado como garantia do empréstimo, a contrapartida de capital próprio $(E)$ e

\footnotetext{
${ }^{8}$ Em política, esses sistemas são chamados de "checks and balances".
} 
um valor subsidiado $(S)$. O colateral é executado em caso de inadimplência do contrato. Nessa situação, o valor líquido do colateral recebido pelos bancos equivale ao valor total do empreendimento $(K)$, descontadas as despesas de execução do colateral $(D): K-D$. Essas despesas são custos de transação incorridos por conta de os bancos não conseguirem controlar o comportamento dos tomadores de empréstimo. ${ }^{9}$ Envolvem despesas administrativas e judiciais, assim como o custo de espera da retomada do colateral, que tem efeitos financeiros para os bancos. Para simplificar, assume-se que o contrato estabelece dois períodos de tempo: no período $t$, há a tomada de crédito e, em $t+1$, o tomador de empréstimo deve retornar o principal e os juros.

Por hipótese, o valor do empréstimo é uma parte do colateral $(K)$, já descontado o montante de subsídio e de contrapartida do empréstimo (capital próprio). A equação (2.1) estabelece essa relação, em que $\lambda_{B}$ é o percentual do valor do empreendimento, já descontado o subsídio, que é financiado $-0<\lambda_{B} \leq 1$. O restante $\left(1-\lambda_{B}\right)$ equivale à parcela de recursos próprios exigida pelo banco para o financiamento - a contrapartida de capital próprio do contrato $(E)$. Assume-se que $0 \leq S \leq C$.

$$
K=B+E+S, \quad B=\lambda_{B} \cdot(K-S) \text { e } E=\left(1-\lambda_{B}\right) \cdot(K-S) .
$$

O cumprimento do contrato depende de duas condições financeiras básicas e de uma distribuição de probabilidade de adimplência. A primeira condição financeira impõe que o valor da dívida com os juros não ultrapasse o valor do colateral exigido pelo banco, caso contrário seria vantajoso para o tomador de empréstimo não pagar a dívida e entregar o colateral para o banco no vencimento. Para os bancos, o valor líquido do colateral tem que ser, a priori, maior ou igual ao valor emprestado mais os serviços dos juros, caso contrário as despesas com a recuperação do colateral não são custeadas no contrato. As duas condições são satisfeitas pela expressão (2.2).

$$
K-D \geq B+B . i^{*}, D>0 .
$$

Satisfeita a condição (2.2), o contrato será cumprido ou não conforme um conjunto de condições que afetam a probabilidade de adimplência. $O$ conjunto é composto pela taxa de juros, pelo risco do negócio e pela riqueza do tomador de empréstimo. Definindo $p$ como a probabilidade de adimplência do contrato de financiamento no período $t+1$, supõe-se que $p$ seja função decrescente do risco do negócio $(\eta)$ e da taxa de juros de financiamento $\left(i^{*}\right)$ e

\footnotetext{
${ }^{9}$ Por simplicidade, assume-se que não há custos de transação no caso de adimplência do contrato. Exemplos desse tipo de custos são despesas com cartórios e registros, impostos de transação etc.
} 
crescente da riqueza dos empreendedores $(W)$, como descrito pelas equações (2.3) e (2.4). Além dessas relações, assume-se que a probabilidade $p$ dependa das instituições que garantem os direitos das partes, promovem o adimplemento dos contratos e evitam o comportamento oportunista dos devedores. Por simplicidade, define-se a existência de dois estados institucionais, um deles com maior probabilidade de inadimplência, para os mesmos valores de $\eta, i^{*}$ e $W: p_{1}<p_{2}$ e $\left(1-p_{1}\right)>\left(1-p_{2}\right)$. Um progresso institucional é visto como a transição entre os estados 1 e 2, a qual provoca uma queda na probabilidade de inadimplência, tudo o mais constante.

$$
p_{j} \in[0,1] \text {, tal que } p_{j}=f\left(\eta, i^{*}, W\right), j=1,2 \text {. }
$$

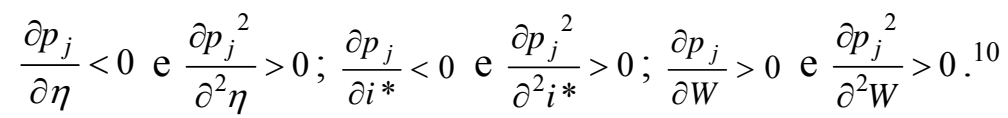

$p_{1}=f\left(\eta, i^{*}, W\right)<p_{2}=f\left(\eta, i^{*}, W\right)$, para todos os valores de $\eta, i^{*}, W$.

O retorno esperado dos bancos depende dos parâmetros do contrato, da probabilidade de adimplência e das despesas de recuperação do colateral em caso de inadimplência. Assume-se que as mudanças institucionais visam à redução das despesas de recuperação do colateral, agindo positivamente sobre o retorno dos credores.

A Figura 2.1 mostra o retorno dos bancos em cada caso. Se o tomador de empréstimo honrar o contrato, o banco chega ao seguinte balanço: ele despende o montante emprestado e recebe esse montante acrescido dos serviços de juros do financiamento. Se o tomador do empréstimo não honrar o contrato, o banco perde o montante emprestado e recebe o valor esperado do colateral $(K-D)$. Para simplificar, assume-se que o valor do empreendimento em $t+1$ seja igual ao valor em $t$, ou ainda, desconsidera-se a valorização do empreendimento ou a depreciação ao longo do tempo.

\section{Figura 2.1 Retornos do empréstimo conforme cenário de adimplência}

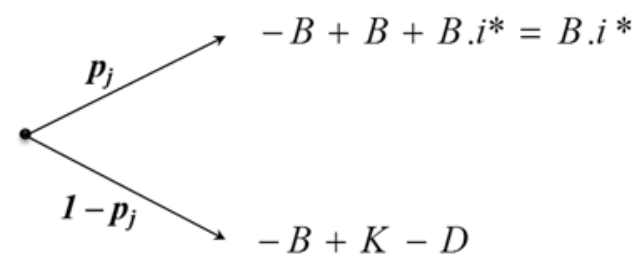

\footnotetext{
${ }^{10}$ Vale lembrar que, por construção, $p$ está limitado ao intervalo entre zero e um. Quando $p$ atinge os valores extremos (0 ou 1), as derivadas de $p$ tornam-se nulas.
} 
Considerando as duas possibilidades, adimplência e inadimplência, o retorno esperado do banco (П) é uma função da taxa de juros do financiamento, do montante de subsídio, do montante emprestado e da despesa de recuperação - equação (2.6). Define-se a taxa de retorno esperada dos bancos como o retorno esperado dividido pelo montante emprestado - expressão (2.7).

$$
\begin{aligned}
& \Pi\left(i^{*}, S, B, D\right)=p_{j} \cdot B \cdot i^{*}+\left(1-p_{j}\right) \cdot(K-B-D) \\
& \rho\left(i^{*}, S, B, D\right)=\frac{\Pi\left(i^{*}, S, B, D\right)}{B}=p_{j} . i^{*}+\left(1-p_{j}\right) \cdot\left(\frac{K-B-D}{B}\right)
\end{aligned}
$$

Para definir o equilíbrio, parte-se da premissa de que os bancos são maximizadores de lucro. Desse modo, a taxa de juros utilizada no financiamento será aquela que maximiza o retorno esperado dos bancos, conforme proposto por Stiglitz e Weiss (1981). Tirando a derivada da taxa de retorno esperado dos bancos em relação à $i^{*}$, obtém-se:

$$
\frac{\partial \rho}{\partial i^{*}}=\frac{\partial p_{j}}{\partial i^{*}} i^{*}+p_{j}-\frac{\partial p_{j}}{\partial i^{*}} \cdot(K / B-1)+\frac{\partial p_{j}}{\partial i^{*}} \cdot(D / B) .
$$

Essa relação pode ser maior ou menor que zero a depender da taxa de juros do financiamento e das despesas de execução do colateral. Como a derivada de $p$ em relação à taxa de juros do financiamento é negativa, a primeira e a quarta componentes da soma são negativas. De outro lado, a probabilidade $p_{j}$ é positiva ou nula e a terceira componente da soma é positiva, pois $K>B$ - condição (2.2). Para encontrar a taxa de juros que maximiza a taxa de retorno dos bancos, basta igualar a derivada anterior a zero. Essa condição implica que:

$$
\frac{\partial p_{j}}{\partial i^{*}} \cdot i^{*}=\frac{\partial p_{j}}{\partial i^{*}} \cdot\left(\frac{K-B-D}{B}\right)-p_{j} \text { ou } i^{*}=\left(\frac{K-B-D}{B}\right)-\frac{p_{j}}{\partial p_{j} / \partial i^{*}}
$$

Há, portanto, uma taxa de juros máxima que é positiva, pois $K>B+D-$ condição (2.2),$- p_{j} \in[0,1]$ e $\partial p_{j} / \partial i^{*}<0$. Se a taxa de juros for maior que $i^{*}$, a taxa de retorno dos bancos não será máxima. Para confirmar que $i^{*}$ é um ponto de máximo, basta calcular a segunda derivada da taxa de retorno dos bancos com relação à taxa de juros do financiamento. Essa derivada é negativa porque $\partial p_{j} / \partial i^{*}<0, \partial p_{j}{ }^{2} / \partial^{2} i^{*}>0$ e $K-D \geq B+B . i^{*}$.

$$
\frac{\partial \rho^{2}}{\partial^{2} i^{*}}=\frac{\partial p_{j}^{2}}{\partial^{2} i^{*}} \cdot i^{*}+2 \cdot \frac{\partial p_{j}}{\partial i^{*}}-\frac{\partial p_{j}^{2}}{\partial^{2} i^{*}} \cdot\left(\frac{K-B-D}{B}\right)=2 \cdot \frac{\partial p_{j}}{\partial i^{*}}-\frac{\partial p_{j}^{2}}{\partial^{2} i^{*}} \cdot\left(\frac{K-B-B \cdot i^{*}-D}{B}\right)<0 .
$$


O mais importante, contudo, é que as mudanças institucionais interferem no retorno esperado dos bancos. Conforme o marco institucional é adequado para reduzir as despesas de execução do colateral, cresce o retorno dos bancos. Além disso, um progresso institucional que eleva a probabilidade de adimplência dos contratos (de $p_{1}$ para $p_{2}$ ), aumenta o retorno esperado dos bancos, pois a derivada da taxa de retorno dos bancos em relação à probabilidade de adimplência é positiva.

$$
\frac{\partial \rho}{\partial D}=\frac{-\left(1-p_{j}\right)}{B}<0 \text { e } \frac{\partial \rho}{\partial p_{j}}=i^{*}-\left(\frac{K-B-D}{B}\right)>0 .^{11}
$$

O montante de subsídio concedido para o desenvolvimento do empreendimento interfere no retorno esperado dos bancos. Conforme se eleva o valor do subsídio, o montante emprestado pelo banco torna-se menor, porque parte do valor do empreendimento é paga pelo governo. Substituindo a definição de $B$ da equação (2.1) em (2.7), tem-se:

$$
\rho\left(i^{*}, S, B, D\right)=p_{j} \cdot i^{*}+\left(1-p_{j}\right) \cdot\left(K / \lambda_{B} \cdot(K-S)-1\right)=p_{j} \cdot i^{*}+\left(1-p_{j}\right) \cdot\left(\frac{K \cdot\left(1-\lambda_{B}\right)+\lambda_{B} \cdot S}{\lambda_{B} \cdot(K-S)}\right) .
$$

A derivada da taxa de retorno esperada dos bancos em relação ao subsídio é positiva, conforme ilustra a expressão a seguir. Isso significa que, quanto maior o subsídio, maior será a taxa de retorno esperado dos bancos, com as demais variáveis mantidas constantes. A análise da segunda derivada da taxa de retorno em relação ao subsídio mostra que ela cresce a taxas crescentes conforme aumenta o montante de subsídio.

$$
\frac{\partial \rho}{\partial S}=\frac{K \cdot \lambda_{B} \cdot\left(1-p_{j}\right)}{\left[\lambda_{B} \cdot(K-S)\right]^{2}}>0 \text { e } \frac{\partial \rho^{2}}{\partial^{2} S}=\frac{2 \cdot K \cdot \lambda_{B}{ }^{2} \cdot\left(1-p_{j}\right)}{\left[\lambda_{B} \cdot(K-S)\right]^{3}}>0 .
$$

O progresso institucional que altera a probabilidade de adimplência dos contratos interfere positivamente na taxa de financiamento $i^{*}$ que maximiza o retorno dos bancos. Esse efeito é calculado pela derivada da taxa de juros do empréstimo em relação à probabilidade de adimplência $p$. A redução das despesas de execução do colateral $(D)$, que também é fruto de mudanças institucionais, afeta positivamente a taxa de juros de equilíbrio, dado que a derivada de $i^{*}$ em relação a $D$ é negativa.

$$
\left.\frac{\partial i^{*}}{\partial p_{j}}\right|_{\rho \max }=-\frac{1}{\partial p_{j} / \partial i^{*}}>0 \text { e }\left.\frac{\partial i *}{\partial D}\right|_{\rho \max }=-\frac{1}{B}<0 .
$$

\footnotetext{
${ }^{11}$ Porque $i^{*}>\left(\frac{K-B-D}{B}\right)$ na condição de equilíbrio (2.8).
} 
Outro aspecto importante é que o subsídio interfere na taxa de financiamento $i^{*}$ que maximiza o retorno dos bancos - equação (2.8). Como o valor do subsídio está contido em $B$, uma mudança no valor do subsídio interfere na taxa de equilíbrio. Tirando a derivada da equação (2.8) com relação a $S$, segue:

$$
\left.\frac{\partial i^{*}}{\partial S}\right|_{\rho \max }=\frac{K \cdot \lambda_{B}}{\left[\lambda_{B} \cdot(K-S)\right]^{2}}>0
$$

Assim, quanto maior o subsídio, maior a taxa de financiamento, pois o aumento do valor de subsídio desloca a curva de retorno esperada dos bancos - ver Figura 2.2. Para a mesma taxa de juros, o subsídio maior implica um retorno também maior. Contudo, o aumento do subsídio implica que a taxa de juros de financiamento que maximiza o retorno dos bancos é maior.

Como o desenvolvimento institucional afeta positivamente o retorno dos empréstimos bancários, seja pela redução das despesas de recuperação do colateral, seja pelo aumento da probabilidade de adimplência dos contratos, ele também influi na oferta de crédito para aquisição de bens de capital (B). Para visualizar essa influência do progresso institucional, vale recorrer ao diagrama proposto por Stiglitz e Weiss (1981) e descrito no Capítulo 1. Nesta seção, a oferta de crédito é designada por $B^{S}$. O primeiro quadrante da Figura 2.2 traz a relação da oferta de crédito com a taxa de juros de financiamento. Observa-se que a oferta de crédito é crescente com relação à taxa de juros até o ponto $i^{*}$. A partir desse ponto, a oferta cai conforme aumenta a taxa de juros. O nível de taxa de juros que maximiza o retorno esperado dos bancos determina a oferta de crédito $\left(B^{S}=B^{*}\right)$.

\section{Figura 2.2 Efeito do subsídio e das instituições sobre a oferta de crédito}

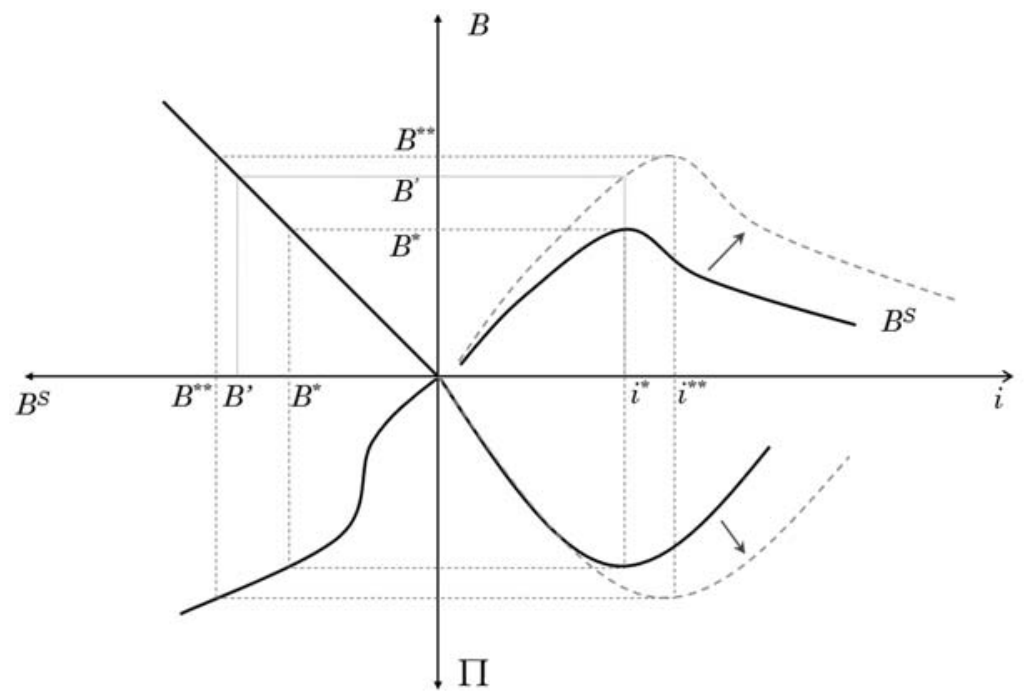


No gráfico, o progresso institucional que favorece o adimplemento dos contratos desloca para cima a curva de retorno esperado dos bancos (quadrante $\Pi$ por $i$ ), o que implica um aumento da oferta de crédito (quadrante $\Pi$ por $B$ ). Essas mudanças afetam a relação entre a taxa de juros do financiamento e a oferta de crédito: há o deslocamento para cima da curva de oferta de crédito no quadrante $B$ por $i$. Esse deslocamento significa que, para a mesma taxa de juros $\left(i^{*}\right)$, a mudança institucional traduz-se em maior oferta de crédito (aumento de $B^{*}$ para $B^{\prime}$ ). Há ainda a expansão da quantidade ofertada de crédito de $B^{\prime}$ para $B^{* *}$ devido ao aumento da taxa de juros do financiamento de $i^{*}$ para $i^{* *}$. Vale observar, por

fim, que um aumento do subsídio ao investimento tem os mesmos efeitos de uma mudança institucional, qual seja, o deslocamento superior da curva $B^{S}$ com aumento da taxa de juros do financiamento e do volume de crédito ofertado.

\subsection{Acumulação de capital e crescimento}

O modelo dinâmico de investimento proposto neste capítulo segue as formulações da seção anterior com relação ao papel das instituições e do subsídio na oferta de crédito e os princípios analisados no Capítulo 1, que destacou as principais variáveis determinantes da formação de capital. Além disso, também é discutida a influência das mudanças institucionais sobre o retorno dos negócios, uma das variáveis-chave na determinação do investimento. A primeira subseção apresenta o modelo de acumulação de capital e a segunda, seus efeitos sobre o crescimento econômico, tomando por base a contabilidade do crescimento.

\subsubsection{Instituições, retorno do capital e investimento}

A produção da economia é dada pela equação (2.9), a qual é parecida com a função de produção descrita no Capítulo 1 - expressão (1.3). Nessa equação, $Y$ é o produto (medido em unidades monetárias), $A$ é o nível de produtividade, $K$ é o estoque de capital e $N$ é a força de trabalho. A diferença reside no fato de que nela há uma variável que mede a produtividade dos fatores $(A)$ e outra $(u)$ que mede a ineficiência causada pelos custos de transação e outras perdas relativas ao arcabouço institucional. Essa premissa permite separar os efeitos sobre a renda de mudanças institucionais daqueles associados à acumulação de fatores e à evolução da produtividade. A abordagem de ineficiência é amplamente aplicada em análises microeconômicas e também foi utilizada em estudos recentes sobre a produtividade de fatores em níveis mais agregados - a esse respeito ver Kneller e Stevens (2003), Kumbhakar e Wang (2005), Garcia et al (2008), Pires e Garcia (2012) e Araujo et al (2014). 
$Y \equiv f(A, K, N) \cdot \exp (-u)$, sendo $\frac{\partial Y}{\partial K}>0, \frac{\partial Y^{2}}{\partial^{2} K}<0, \frac{\partial Y}{\partial N}>0, \frac{\partial Y^{2}}{\partial^{2} N}<0, u \geq 0 e \frac{\partial Y}{\partial u}<0$.

O estoque de capital da economia é composto por uma parcela de capital próprio dos empreendedores $\left(K^{E}\right)$, pelo capital constituído com endividamento junto aos bancos $\left(K^{B}\right)$ e aquele formado com os subsídios concedidos no passado $\left(K^{S}\right)$ - expressão (2.10). A renda gerada com a produção $(Y)$ remunera o trabalho, o capital dos bancos que emprestaram o valor $K^{B}$ à taxa de juros $i^{*}$ e o lucro do empreendedor $\left(\Pi^{\mathrm{K}}\right)$. A equação (2.11) apresenta essa relação, em que $w$ é o salário médio.

(2.10) $K=K^{E}+K^{B}+K^{S}$, ou ainda, $K^{B}=K-K^{E}-K^{S}$.

(2.11) $Y \equiv \Pi^{K}+i^{*} \cdot K^{B}+w \cdot N$, ou ainda, $\Pi^{K} \equiv Y-i^{*} \cdot B-w \cdot N$.

As empresas contratam as quantidades de mão de obra e de capital que geram o maior retorno do empreendimento, restritas às limitações tecnológicas, à disponibilidade de fatores e aos preços ( $w$ e $\left.i^{*}\right)$. Seguindo as formulações das teorias dinâmicas do capital, o valor dos ativos $Q$ é definido como a relação entre o preço de mercado do empreendimento e seu custo de reposição. Quando o preço de mercado do bem de capital é maior que seu custo de reposição, há um incentivo ao investimento. O retorno dos ativos é formado por três componentes: a valorização dos ativos $(\dot{Q})$, o retorno do empreendimento $\left(\Pi^{K}\right)$ e a depreciação física dos ativos, que é uma proporção $(\delta)$ do valor do empreendimento $Q$. A taxa de retorno do ativo $\left(r^{K}\right)$ é definida como a relação entre o retorno e o preço do ativo equação (2.12).

(2.12) $r^{K} \equiv \frac{\dot{Q}+\Pi^{K}-\delta \cdot Q}{Q}$.

Rearranjando a expressão (2.12), e empregando as definições (2.10) e (2.11) chegase à equação dinâmica de valorização dos ativos:

$\dot{Q}=\left(r^{K}+\delta\right) \cdot Q-Y+i^{*} \cdot K^{B}+w \cdot N=\left(r^{K}+\delta\right) \cdot Q-f(A, K, N) \cdot \exp (-u)+i^{*} \cdot\left(K-K^{E}-K^{S}\right)+w \cdot N$

Para completar o modelo, emprega-se uma equação de variação do estoque de capital no tempo. Por definição, o estoque de capital em $t$ é igual ao capital em $t-1$, menos a depreciação do capital em $t$, acrescido o investimento - equação (2.14).

(2.14) $\dot{K}=I-\delta . K$. 
A função de investimento é dada pela agregação de duas sub-funções: (i) dos empresários que se autofinanciam, ou seja, não participam do mercado de crédito; e (ii) dos empresários que necessitam de crédito para financiar parte dos seus empreendimentos. A função investimento autônomo $\left(I^{a}\right)$ é definida pela equação (2.15) em que o investimento responde positivamente ao valor dos ativos. A função investimento com financiamento é definida como a soma do investimento financiado $\left(\phi\left(i^{*}, S, D\right)\right)$ com o valor do investimento feito com capital próprio $\left(\theta_{B} \cdot Q\right)$. O volume do investimento dado em contrapartida do crédito responde ao preço dos ativos, como na equação (2.15), e o valor financiado responde às variáveis determinantes do volume de crédito concedido pelos bancos: a taxa de juros de empréstimo $\left(i^{*}\right)$, o fluxo de subsídios $(S)$ e as despesas com recuperação do colateral $(D)$.

$$
\begin{aligned}
& I^{A} \equiv \theta_{A} \cdot Q, \theta_{A}>0 \\
& I^{B}=\theta_{B} \cdot Q+\phi\left(i^{*}, S, D\right), \quad \frac{\partial \phi(\bullet)}{\partial i^{*}}>0, \frac{\partial \phi(\bullet)}{\partial S}>0 \text { e } \frac{\partial \phi(\bullet)}{\partial D}<0
\end{aligned}
$$

O investimento total da economia - expressão (2.17) - é a soma dos investimentos dos dois tipos de empreendedores, que é idêntica à soma das expressões (2.15) e (2.16). Substituindo o investimento na definição da variação no tempo do estoque de capital, chega-se à expressão de acumulação de capital (2.18).

$$
I \equiv I^{A}+I^{B} \equiv \theta_{A} \cdot Q+\theta_{B} \cdot Q+\phi\left(i^{*}, S, D\right) \equiv \theta \cdot Q+\phi\left(i^{*}, S, D\right), \text { em que } \theta=\theta_{A}+\theta_{B}
$$

(2.18) $\dot{K}=\theta . Q+\phi\left(i^{*}, S, D\right)-\delta . K$.

As equações (2.13) e (2.18) formam o sistema de equações diferenciais que define o equilíbrio dinâmico do investimento. ${ }^{12} \mathrm{O}$ equilíbrio do sistema é encontrado no estado estacionário das variáveis $Q$ e $K$. As expressões (2.19) e (2.20) descrevem as curvas de equilíbrio de estado estacionário do preço dos ativos e do estoque de capital. A curva descrita pela equação (2.19) tem inclinação negativa e a curva descrita pela equação (2.20) tem inclinação positiva. O equilíbrio é definido na interseção das duas curvas e os valores que equilibram o sistema são apresentados nas expressões (2.22) e (2.23).

\footnotetext{
$12 \mathrm{O}$ sistema possui estabilidade de sela, pois o determinante Jacobiano é negativo. Isso ocorre porque a condição de maximização do retorno dos lucros dos empreendimentos e a premissa de que a taxa marginal de substituição técnica por fatores é negativa implica que $i^{*}>\partial Y / \partial K$.
}

$$
\left.|J|=\mid \begin{array}{cc}
\left(r^{K}+\delta\right) & \left(i^{*}-\frac{\partial Y}{\partial K}\right. \\
\theta & -\delta
\end{array}\right)=-\delta \cdot\left(r^{K}+\delta\right)-\left(i^{*}-\frac{\partial Y}{\partial K}\right) \cdot \theta<0 .
$$




$$
\dot{Q}=0 \Rightarrow Q=\frac{Y-w \cdot N-i^{*} \cdot\left(K-K^{E}-K^{S}\right)}{\left(r^{K}+\delta\right)},\left.\frac{d Q}{d K}\right|_{\dot{Q}=0}=\left(\frac{\partial Y}{\partial K}-i^{*}\right) \cdot \frac{1}{r^{K}+\delta}<0
$$

$$
\dot{K}=0 \Rightarrow K=\frac{\theta \cdot Q+\phi\left(i^{*}, S, D\right)}{\delta},\left.\frac{d Q}{d K}\right|_{\dot{k}=0}=\frac{\delta}{\theta}>0
$$

$$
Q^{*}=\frac{\delta\left(Y-w \cdot N+i^{*} \cdot\left(K^{E}+K^{S}\right)\right)-i^{*} \cdot \phi\left(i^{*}, S, D\right)}{\delta \cdot\left(r^{K}+\delta\right)+i^{*} \cdot \theta}
$$

$$
K^{*}=\frac{\left(r^{K}+\delta\right) \cdot \phi\left(i^{*}, S, D\right)+\theta \cdot\left(Y-w \cdot N+i^{*} \cdot\left(K^{E}+K^{S}\right)\right)}{\delta \cdot\left(r^{K}+\delta\right)+i^{*} \cdot \theta}
$$

Por fim, cabe avaliar os efeitos das mudanças das variáveis-chave do sistema sobre o equilíbrio de estado estacionário. As variáveis analisadas são: o fluxo de subsídios $(S)$, os custos de recuperação do colateral $(D)$, a probabilidade de adimplência $\left(p_{j}\right)$ e a ineficiência na produção $(u)$. Para analisar as derivadas de $Q^{*}$ e $K^{*}$ em relação ao fluxo de subsídios e às despesas de recuperação do colateral é necessário calcular antes as derivadas de $Q^{*}$ e $K^{*}$ em relação à função $\phi(\bullet)$.

$$
\frac{\partial Q *}{\partial \phi(\bullet)}=\frac{-i *}{\delta \cdot\left(r^{K}+\delta\right)+i^{*} . \theta}<0 \text { e } \frac{\partial K *}{\partial \phi(\bullet)}=\frac{r^{K}+\delta}{\delta \cdot\left(r^{K}+\delta\right)+i^{*} \cdot \theta}>0
$$

A expressão anterior indica que um aumento do fluxo de crédito concedido pelos bancos afeta positivamente o estoque de capital de equilíbrio de estado estacionário e reduz o preço dos ativos. Como o fluxo de subsídios afeta positivamente o montante de crédito concedido pelos bancos, conforme discutido na seção anterior e proposto na equação (2.16), pode-se esperar um impacto positivo do aumento de subsídios sobre o estoque de capital de estado estacionário e negativo no valor de equilíbrio dos ativos. Uma redução das despesas com a recuperação do colateral também tem efeito positivo sobre o volume de crédito concedido pelos bancos, o que acarreta diminuição do preço dos ativos e aumento do estoque de capital de estado estacionário.

Uma mudança na probabilidade de adimplência dos contratos aumenta o crédito concedido pelos bancos, mas, como visto na seção anterior, essa variação também eleva a taxa de juros de maximização dos lucros dos bancos. O primeiro movimento tem impacto positivo sobre o estoque de capital de estado estacionário e negativo, no caso do valor dos ativos. O segundo movimento depende dos sinais das derivadas de $Q^{*}$ e $K^{*}$ em relação ao à taxa de juros de financiamento $(i *)$. Esses efeitos são descritos pelas expressões apresentadas a seguir: 


$$
\begin{aligned}
& \frac{\partial Q *}{\partial i^{*}}=\frac{\delta \cdot\left(r^{K}+\delta\right) \cdot\left[\delta\left(K^{E}+K^{S}\right)-\phi(\bullet)-i^{*} \cdot \partial \phi(\bullet) / \partial i^{*}\right]-i^{*} \cdot \partial \phi(\bullet) / \partial i^{*} \cdot \theta}{\left[\delta \cdot\left(r^{K}+\delta\right)+i^{*} \cdot \theta\right]^{2}} \mathrm{e} \\
& \frac{\partial K *}{\partial i^{*}}=\frac{\delta \cdot\left(r^{K}+\delta\right) \cdot\left[\delta\left(K^{E}+K^{S}\right)-\phi(\bullet)\right]+\partial \phi(\bullet) / \partial i^{*} \cdot\left(r^{K}+\delta\right) \cdot\left[\delta \cdot\left(r^{K}+\delta\right)+i^{*} \cdot \theta\right]}{\left[\delta \cdot\left(r^{K}+\delta\right)+i^{*} \cdot \theta\right]^{2}} .
\end{aligned}
$$

As duas expressões têm sinais indeterminado, mas há uma condição em que o sinal da derivada de $Q^{*}$ em relação $i^{*}$ se torna negativo e o da derivada de $K^{*}$ em relação a $i^{*}$, positivo. A condição é que $\phi(\bullet)>\delta\left(K^{E}+K^{S}\right)$, ou seja, que o crédito concedido pelos bancos seja superior ao montante necessário para repor a depreciação do estoque de capital próprio dos empreendedores e aquele acumulado com a concessão de subsídios. Nessa situação, o segundo movimento teria o mesmo sentido que o primeiro, indicando que o aumento da probabilidade de adimplência dos contratos reduz o preço dos ativos e eleva o estoque de capital de estado estacionário.

Finalmente, uma redução da ineficiência da atividade econômica advinda de um progresso institucional tem efeito positivo sobre o preço dos ativos e sobre o estoque de capital de estado estacionário, porque eleva o retorno do capital para o empreendedor. As derivadas a seguir descrevem essas relações.

$$
\frac{\partial Q *}{\partial u}=\frac{\delta \cdot \partial Y / \partial u}{\delta \cdot\left(r^{K}+\delta\right)+i^{*} . \theta}<0 \text { e } \frac{\partial K *}{\partial u}=\frac{\theta \cdot \partial Y / \partial u}{\delta \cdot\left(r^{K}+\delta\right)+i^{*} \cdot \theta}<0 .
$$

Em resumo, as mudanças institucionais que reduzem as despesas de recuperação do colateral afetam positivamente o crédito e, portanto, têm efeitos de longo prazo no equilíbrio estacionário, elevando o estoque de capital da economia e reduzindo o preço dos ativos. As mudanças institucionais que produzem um aumento da probabilidade de adimplência também ampliam a oferta de crédito. Contudo, elas elevam a taxa de juros do financiamento, porque o volume maior de crédito aumenta o risco. O efeito final sobre o estoque de capital é positivo a depender do valor de crédito alcançado e do valor da depreciação dos estoques de capital próprio e subsidiado. As mudanças institucionais que levam à redução da ineficiência do setor produtivo, por outro lado, ampliam o retorno dos empreendedores e, portanto, têm impactos positivos sobre o estoque de capital e o valor dos ativos da economia.

\subsubsection{Impactos sobre o crescimento}

É importante observar, neste ponto, que essas mudanças institucionais afetam o equilíbrio de longo prazo da economia porque alteram os retornos dos empreendedores e 
dos bancos. No primeiro caso, estimulam o investimento diretamente e, no segundo, elevam a disponibilidade de crédito, com efeito positivo sobre o investimento. Assim, as mudanças institucionais estão implícitas na evolução desse conjunto de variáveis.

A equação (2.23) resume as relações entre investimento e seus fatores determinantes, em que $\mathbf{x}$ é um vetor de variáveis formado pela oferta de crédito para investimento, o retorno dos empreendedores - que é o retorno bruto do capital $(Y-w \cdot N)$, descontado o pagamento de juros aos bancos - e o valor dos ativos. Por construção, a variação no tempo dos investimentos é dada pela soma das variações no tempo das variáveis em $\mathbf{x}$, ponderada pelas respectivas derivadas parciais do investimento em relação à $\mathbf{x}$.

(2.23) $I=f(\mathbf{x}), \frac{d I}{d t}=\frac{\partial I}{\partial \mathbf{x}} \cdot \dot{\mathbf{x}}$.

Os efeitos da evolução das variáveis determinantes do investimento sobre o crescimento econômico de um país podem ser mensurados a partir da contabilidade de crescimento. Diferenciando a função de produção (2.9) no tempo, chega-se à expressão (2.24) após algumas manipulações, em que $g$ são as taxas de crescimento das variáveis em nível, $S_{K}$ e $S_{N}$ são, respectivamente, as participações do capital e do trabalho na renda e $\dot{u}$ é a variação da ineficiência. Essa equação mostra que a taxa de crescimento econômico é composta pela evolução da produtividade de fatores, pela acumulação de capital, pela expansão da força de trabalho e pela variação da ineficiência.

$$
g_{Y}=g_{A}+s_{K} \cdot g_{K}+s_{N} \cdot g_{N}-\dot{u}
$$

Diferenciando no tempo a expressão (2.24), tem-se a variação da taxa de crescimento econômico entre dois períodos. Ela é uma composição das variações no tempo do aumento da produtividade de fatores, da taxa de acumulação de capital, da taxa de expansão da força de trabalho e da taxa de variação da ineficiência.

(2.25) $\frac{d g_{Y}}{d t}=\frac{d g_{A}}{d t}+s_{K} \cdot \frac{d g_{K}}{d t}+s_{N} \cdot \frac{d g_{N}}{d t}-\frac{d \dot{u}}{d t}$.

A partir da equação (2.14) é possível definir a taxa de crescimento do estoque de capital como sendo $g_{K}=I / K-\delta$. Diferenciando essa taxa em relação ao tempo, segue a equação (2.26):

(2.26) $\frac{d g_{K}}{d t}=\frac{d I}{d t} \cdot \frac{1}{K}-g_{K} \cdot \frac{I}{K}$.

Substituindo a expressão (2.23) em (2.26), chega-se à equação que mede o efeito das mudanças nas variáveis determinantes do investimento na evolução da taxa de acumulação de capital - equação (2.27). Finalmente, substituindo essa equação em (2.25), 
obtém-se a expressão (2.28), a qual mede o efeito das mudanças nas variáveis determinantes do investimento na evolução da taxa de crescimento econômico.

(2.27) $\frac{d g_{K}}{d t}=\frac{\partial I}{\partial \mathbf{x}} \cdot \dot{\mathbf{x}} \cdot \frac{1}{K}-g_{K} \cdot \frac{I}{K}$.

(2.28) $\frac{d g_{Y}}{d t}=\frac{d g_{A}}{d t}+s_{K} \cdot\left[\frac{\partial I}{\partial \mathbf{x}} \cdot \dot{\mathbf{x}} \cdot \frac{1}{K}-g_{K} \cdot \frac{I}{K}\right]+s_{N} \cdot \frac{d g_{N}}{d t}-\frac{d \dot{u}}{d t}$.

Assim, é direta a visualização dos efeitos da evolução das variáveis determinantes do investimento - oferta de crédito, taxas de juros do financiamento, retorno do capital e preços dos ativos. Com base em estimativas econométricas das derivadas parciais do investimento em relação a seus fatores determinantes, e tomando por referência os dados de contabilidade social das economias, é possível mensurar empiricamente os efeitos da evolução da oferta de crédito, das taxas de juros do financiamento, do retorno do capital e dos preços dos ativos sobre a evolução das taxas de acumulação de capital e de crescimento econômico das nações. 


\section{Capítulo 3}

\section{Crédito e investimento no contexto mundial}

Os conceitos teóricos desenvolvidos no capítulo anterior estabelecem relações positivas entre o investimento, de um lado, e a oferta de crédito e a taxa de retorno do capital, de outro. Também com base nesses conceitos, tem-se que variações na taxa de juros e no preço dos ativos influenciam negativamente a formação de capital. De fato, os dados de uma amostra de 39 economias sugerem que essas relações são válidas do ponto de vista empírico.

A Tabela 3.1 traz os níveis e taxas médias anuais de crescimento do investimento, do crédito e do retorno do capital entre 1995 e 2011 para esses países. ${ }^{13}$ As informações são provenientes de duas bases de dados: o World Input-Output Database (Timmer, 2014) e o World Development Indicators (World Bank, 2014), o qual foi empregado para completar as informações que faltavam na primeira base de dados. ${ }^{14}$ Nota-se que a China, a Índia e a Austrália apresentaram as maiores taxas de crescimento do investimento de, respectivamente, 11,6\% a.a., 10,1\% a.a. e 9,2\% a.a. Esses países também apresentaram taxas de crescimento do crédito bastante elevadas. Por outro lado, o Japão e Alemanha apresentaram estagnação do investimento e do crédito.

As maiores taxas de retorno do capital (médias entre 1995 e 2011) foram observadas na China e Índia, países que também registraram aumentos expressivos do retorno do capital entre 2000 e 2011, o que ajuda a explicar o comportamento do investimento. $\mathrm{Na}$ China, a formação bruta de capital cresceu à taxa média anual de 11,6\% e, na Índia, à taxa de $10,1 \%$. De outro lado, a redução da taxa de retorno do capital nas economias da União Europeia (Bélgica, Reino Unido, Itália e Portugal, por exemplo) justifica o baixo crescimento dos investimentos.

Neste capítulo, essas ideias são avaliadas por meio de uma análise econométrica com base na amostra de 39 países. Antes disso, a seção 3.1 traz uma discussão sobre a literatura empírica relacionada aos determinantes do investimento e sua relação com o crédito. Além de dar suporte para as análises econométricas desenvolvidas nas seções

\footnotetext{
${ }^{13}$ No caso do retorno do capital, a taxa média de crescimento refere-se ao período 2000 a 2011 para evitar a distorção causada pela presença na amostra de economias em transição - Polônia, por exemplo.

${ }^{14}$ Como essas bases serão amplamente empregads na tese, optou-se por elas serem referidas simplesmente por WIOD e WDI, inclusive nas fontes de tabelas e gráficos. Ver descrição das variáveis na seção 3.2.2.
} 
seguintes, essa discussão serve de contraponto para avaliar os resultados obtidos. A seção 3.2 traz a metodologia e as estimativas econométricas. A seção seguinte faz uma análise de sensibilidade, testando a substituição da taxa de retorno efetivo pela taxa de retorno esperado do capital e a inclusão de outras variáveis no modelo empírico. Finalmente, a seção 3.4 avalia o efeito da dinâmica dessas variáveis sobre as taxas de acumulação de capital e de crescimento econômico das nações.

Tabela 3.1. Investimento, crédito e retorno do capital, 1995 a 2011, médias e variações anuais (\%)

\begin{tabular}{|c|c|c|c|c|c|c|}
\hline \multirow[b]{2}{*}{ Países } & \multicolumn{3}{|c|}{ Média* } & \multicolumn{3}{|c|}{ Variação anual** } \\
\hline & $\begin{array}{r}\text { Investimento } \\
(\mathrm{em} \text { In) } \\
\end{array}$ & $\begin{array}{l}\text { Crédito } \\
\text { (em In) }\end{array}$ & $\begin{array}{r}\text { Retorno } \\
\text { do Capital }(\%) \\
\end{array}$ & Investimento & Crédito & $\begin{array}{r}\text { Retorno } \\
{\text { do } \text { Capital }^{\dagger}}\end{array}$ \\
\hline Austrália & 25,910 & 26,835 & $9,7 \%$ & $9,2 \%$ & $7,0 \%$ & $-3,2 \%$ \\
\hline Áustria & 24,919 & 26,343 & $8,3 \%$ & $2,6 \%$ & $3,7 \%$ & $0,2 \%$ \\
\hline Bélgica & 24,965 & 26,198 & $9,2 \%$ & $2,4 \%$ & $3,4 \%$ & $-1,4 \%$ \\
\hline Bulgária & 22,049 & 22,362 & $9,8 \%$ & $5,1 \%$ & $5,6 \%$ & $-1,6 \%$ \\
\hline Canadá & 25,680 & 27,576 & $13,1 \%$ & $3,8 \%$ & $6,3 \%$ & $0,0 \%$ \\
\hline China & 27,061 & 28,135 & $26,8 \%$ & $11,6 \%$ & $12,7 \%$ & $5,0 \%$ \\
\hline Chipre & 21,553 & 23,832 & $9,3 \%$ & $3,9 \%$ & $8,9 \%$ & $-0,6 \%$ \\
\hline República Checa & 23,943 & 24,053 & $8,1 \%$ & $3,7 \%$ & $1,3 \%$ & $-0,9 \%$ \\
\hline Alemanha & 27,161 & 28,681 & $8,4 \%$ & $2,0 \%$ & $1,6 \%$ & $0,0 \%$ \\
\hline Finlândia & 24,263 & 25,341 & $9,9 \%$ & $4,0 \%$ & $5,7 \%$ & $-1,9 \%$ \\
\hline França & 26,615 & 28,042 & $8,3 \%$ & $2,2 \%$ & $3,7 \%$ & $-0,2 \%$ \\
\hline Reino Unido & 26,446 & 28,279 & $11,3 \%$ & $3,5 \%$ & $5,3 \%$ & $-2,3 \%$ \\
\hline Grécia & 24,330 & 25,326 & $13,9 \%$ & $1,2 \%$ & $11,3 \%$ & $-4,0 \%$ \\
\hline Hungria & 23,618 & 23,791 & $7,2 \%$ & $5,2 \%$ & $9,6 \%$ & $0,6 \%$ \\
\hline Indonésia & 24,882 & 25,237 & $22,3 \%$ & $4,1 \%$ & $0,5 \%$ & $3,3 \%$ \\
\hline Índia & 25,913 & 26,054 & $20,0 \%$ & $10,1 \%$ & $13,0 \%$ & $2,1 \%$ \\
\hline Irlanda & 24,329 & 25,694 & $14,3 \%$ & $5,7 \%$ & $11,9 \%$ & $-5,6 \%$ \\
\hline Itália & 26,380 & 27,521 & $8,4 \%$ & $1,9 \%$ & $5,8 \%$ & $-2,5 \%$ \\
\hline Malta & 20,719 & 22,188 & $12,1 \%$ & $-0,3 \%$ & $5,3 \%$ & $-0,8 \%$ \\
\hline Holanda & 25,585 & 27,262 & $8,5 \%$ & $3,6 \%$ & $7,2 \%$ & $-1,1 \%$ \\
\hline Polônia & 24,499 & 24,681 & $8,1 \%$ & $6,5 \%$ & $12,2 \%$ & $7,4 \%$ \\
\hline Portugal & 24,429 & 25,769 & $10,3 \%$ & $2,6 \%$ & $9,2 \%$ & $-3,0 \%$ \\
\hline Romênia & 23,191 & 22,851 & $9,1 \%$ & $5,7 \%$ & $12,4 \%$ & $-0,6 \%$ \\
\hline Rússia & 24,971 & 25,245 & $19,0 \%$ & $3,8 \%$ & $13,8 \%$ & $1,7 \%$ \\
\hline Eslováquia & 22,720 & 23,030 & $16,1 \%$ & $4,6 \%$ & $5,2 \%$ & $1,5 \%$ \\
\hline Eslovênia & 22,790 & 23,237 & $9,2 \%$ & $3,9 \%$ & $11,7 \%$ & $-0,7 \%$ \\
\hline Suécia & 24,834 & 26,375 & $13,4 \%$ & $4,1 \%$ & $4,9 \%$ & $-0,4 \%$ \\
\hline Turquia & 24,967 & 25,004 & $27,7 \%$ & $5,5 \%$ & $12,5 \%$ & $1,9 \%$ \\
\hline Estados Unidos & 25,201 & 27,162 & $15,1 \%$ & $4,3 \%$ & $4,8 \%$ & $-0,6 \%$ \\
\hline
\end{tabular}




\subsection{A literatura empírica sobre a relação entre crédito e investimento}

Greene e Villanueva (1991) analisaram a função de investimento privado em 23 países em desenvolvimento entre 1975 e 1987. Eles partiram da ideia de que as teorias tradicionais do investimento empregadas na análise dos determinantes do investimento em economias desenvolvidas - por exemplo, a teoria do acelerador de crescimento não devem ser aplicadas em países em desenvolvimento, devido ao fato de elas partirem de premissas que não são adequadas a esses países.

A análise econométrica de Greene e Villanueva (1991) baseou-se num painel com estimação por efeito fixo. Para explicar a razão entre investimento privado e PIB, os autores empregaram um amplo conjunto de variáveis explicativas: a taxa real de juros; a taxa de variação do PIB defasada em um período; a razão investimento público e PIB; a variação do índice de preço do consumidor; o nível do PIB per capita em US\$ correntes defasado; a razão dos pagamentos dos serviços da dívida e exportação de bens e serviços defasada; e a razão estoque de dívida externa e PIB nominal defasada. O crédito não fez parte do conjunto de variáveis explicativas do investimento.

O investimento privado apresentou uma relação positiva com a taxa de crescimento do PIB (defasada) e uma relação negativa e significativa com as seguintes variáveis: razão defasada dos serviços da dívida externa, estoque de dívida defasado e taxa de inflação. ${ }^{15}$ No geral, os resultados deram algum suporte para a visão de que economias com altas taxas de investimento privado têm elevadas taxas de crescimento, alto nível de renda, maior estabilidade macroeconômica, menores dívidas e altas taxas de investimento público.

Outros autores que analisaram os determinantes do investimento foram Erden e Holcombe (2005). A análise foi feita por meio de um painel de dezenove países entre 1980 e 1997. Os autores partiram de uma especificação teórica de acelerador de investimento flexível no qual foi assumido que o estoque de capital desejado é proporcional ao nível esperado de produto. Foram empregadas quatro técnicas econométricas: MQO agrupado, efeito fixo, efeito aleatório e MQO em dois estágios. Foi analisado o efeito de sete variáveis sobre o investimento privado: (i) variação do PIB real, (ii) investimento público, (iii) taxa de juros reais, (iv) disponibilidade de crédito, (v) índice de liberdade econômica, (vi) índice de incerteza e (vii) investimento privado defasado.

15 Os autores estimaram outras duas equações para subperíodos: 1975 a 1981 e 1982 a 1987. Os resultados dessas duas equações sugerem que a estimação o período como um todo pode mascarar os resultados de cada subperíodo, pois muitas das variáveis que eram significativas na primeira equação apresentaram coeficientes não significativos nas subamostras. 
Dos modelos estimados, o MQO em dois estágios foi o mais adequado na opinião dos autores. Para os países em desenvolvimento, uma aceleração do PIB, um aumento do investimento público e um aumento da disponibilidade de crédito tiveram efeitos positivos sobre o investimento privado. $\mathrm{O}$ investimento privado defasado afetava positivamente o seu nível corrente. No caso dos países desenvolvidos, o resultado foi distinto: o investimento privado era afetado positivamente pela variação do PIB e pelo investimento passado, mas negativamente pelo investimento público.

Há outra linha de trabalho, a qual considera os efeitos de aspectos institucionais no investimento. Essa literatura usa índices de risco político e de cumprimento das leis (enforcement) na função de investimento estimada. Dois autores nessa linha são Stasavage (2002) e Le (2004).

A análise de Stasavage (2002) foi feita com base num banco de dados de painel não balanceado contendo informações de 74 países em desenvolvimento entre 1971 e 1994. As relações entre investimento privado, dois índices políticos e um conjunto de variáveis macroeconômicas foram estimadas por efeito fixo e aleatório. As variáveis macroeconômicas empregadas foram: a taxa de crescimento do PIB anual, a taxa de inflação, o nível de crédito ao setor privado (como percentagem do PIB) e o peso das exportações de óleo e minérios no total das exportações.

O primeiro índice político foi desenvolvido por Beck et. al (1999), que buscou capturar a transição de um sistema político autoritário para um sistema no qual o executivo e o legislativo são controlados por poderes separados. O segundo índice foi desenvolvido por Henisz (2000) para medir as restrições políticas dos tomadores de decisão na esfera pública.

$\mathrm{Na}$ análise econométrica de Stasavage (2002), as estimativas sem dummies de país (modelo de dados empilhados ou de efeitos aleatórios) indicaram coeficientes positivos e significativos dos dois índices políticos. Contudo, as estimativas de efeitos fixos apontaram para coeficientes não significativos das variáveis políticas. Em outros termos, quando se considerou que as nações tinham características específicas - as quais são de natureza idiossincrática -, as medidas de instituições políticas perderam seu poder de explicar o comportamento do investimento privado na amostra de países. Além disso, nas estimativas do autor, o investimento privado defasado e a taxa de crescimento 
do PIB afetavam positivamente o investimento privado, mas a variável crédito ao setor privado não apresentou coeficientes muito significativos. ${ }^{16}$

Le (2004) estudou os determinantes políticos e econômicos do investimento em uma amostra de 25 economias em desenvolvimento entre 1975 e 1995 . Ele partiu da ideia de que tanto as falhas econômicas como as falhas políticas e institucionais podem restringir o investimento e o crescimento econômico. Os índices utilizados para medir os determinantes políticos e institucionais foram contribuições de diferentes autores. $\mathrm{O}$ índice de instabilidade político-social (SPI) de Ghate, Le e Zak (2003) foi definido por indicadores de violência política, protestos não violentos e revoltas internas envolvendo o uso da força física e participação do público. ${ }^{17}$ Outro índice empregado foi o de instabilidade de mudança de regime político, o qual separa regimes de mudanças constitucionais do poder executivo de regimes de mudanças inconstitucionais.

O terceiro indicador foi o de incerteza política, a qual é causada por uma mudança na política ao invés de uma mudança de regime político. No artigo, Le (2004) focou em dois tipos de incerteza política: a variabilidade da capacidade de política governamental e a variabilidade de fazer cumprir os contratos (contract enforcement). A capacidade política relativa (RPC) desenvolvida por Organski e Kugler (1980) e Kugler e Arbetman (1997) foi baseada na razão entre a receita corrente do governo e a receita esperada. Para os autores, um país com um alto RPC teria um governo capaz de implementar de maneira eficiente suas políticas. A segunda medida de incerteza, denominada Contrato Intensivo em Dinheiro (CIM), foi desenvolvida por Clague et al. (1999). Ela é um indicador das garantias de direitos de propriedade.

A análise empírica de Le (2004) foi feita por meio da técnica de painel com efeito fixo e efeito aleatório. Foram estimados os efeitos sobre a taxa de investimento (percentagem do PIB) do risco econômico - medido pela taxa de inflação, pela evolução da taxa de câmbio e pelo diferencial de retorno dos títulos públicos em relação à taxa dos títulos do tesouro norte-americano - e do risco político, medido pelos índices descritos anteriormente. Os resultados mostraram que um aumento do risco econômico diminuiu o investimento. Com relação às variáveis sócio-políticas, os resultados mostraram que houve queda do investimento na presença de guerrilhas, violência e rupturas. As mu-

\footnotetext{
${ }^{16}$ As estatísticas $t$ associadas a essa variável ficaram entre 1,83 e 1,65, indicando um $p$-valor relativamente elevado.

${ }^{17}$ O SPI pode ser dividido em dois tipos denominados por: SPIF1 e SPIF2. O primeiro inclui revoltas gerais e demonstrações antigoverno, representado por protestos coletivos. O segundo inclui guerrilhas e assassinatos caracterizados por quebras ou rupturas e revoltas violentas.
} 
danças de poder irregular também afetaram negativamente o investimento dos países da amostra. Além disso, países com alta capacidade política relativa (RPC) apresentaram taxas de investimento privado relativamente maiores.

\subsection{Oferta de crédito e investimento agregado no mundo}

\subsubsection{Estratégia de modelagem}

As análises dos fatores determinantes do investimento discutidas na seção anterior destacaram a contribuição de um conjunto amplo de variáveis econômicas e político-institucionais, as quais foram incorporadas nos modelos econométricos de maneira mais ou menos formal, ou seja, respeitando algum princípio teórico enunciado. Algumas das análises indicaram que o crédito é um fator importante, assim como foi discutido ao longo dos Capítulos 1 e 2 desta tese, e outras destacaram que os fatores políticosinstitucionais afetaram o investimento - mudanças regulares de regime político, alta capacidade de execução de políticas públicas e reduzido grau de incerteza política. Vale notar, contudo, que a maioria dos textos analisados restringiu a amostra à experiência dos países em desenvolvimento.

A abordagem da análise econométrica desenvolvida neste capítulo é distinta dessas formulações discutidas na seção anterior. São duas as diferenças básicas. A primeira diz respeito ao fato de que a escolha das variáveis relevantes para o modelo foi baseada direta e exclusivamente no modelo teórico do Capítulo 2. A segunda reside no fato de que não é incorporado nenhum indicador institucional no conjunto de variáveis explicativas do investimento.

Um exemplo de avaliação econométrica cuja escolha das variáveis explicativas decorreu diretamente de um modelo teórico é encontrado no artigo de Mankiw, Romer e Weil (1992). Os autores derivaram um modelo teórico de crescimento baseado na acumulação de capital físico e humano, na expansão da força de trabalho e no aumento da produtividade e, com base nele, especificaram o modelo econométrico que foi empregado na estimação. Esse tipo de abordagem, conforme destacado por Hoover (2007), segue a ideia de Haavelmo (1944) de que os modelos teóricos definidos a priori têm um peso muito importante no desenho da especificação econométrica. A econometria, nesse sentido, seria configurada como um esforço de mensuração das relações definidas em sistemas causais. 
O posicionamento adotado neste capítulo, contudo, não configura uma defesa metodológica dessa abordagem, mas sim uma opção que é suficiente para os objetivos desta tese: medir a relação entre crédito e investimento, levando em consideração outros fatores que também afetam a formação de capital. Além disso, o conjunto de fatores determinantes do investimento indicado no modelo teórico do Capítulo 2 inclui quase todas as variáveis econômicas empregadas nos textos empíricos sobre o tema analisados na seção anterior: taxa de juros, taxa de inflação, taxa de câmbio e disponibilidade de crédito. As exceções são a taxa de investimento público sobre o PIB - que, neste caso, é parte da variável dependente -, a relação entre dívida e exportações e o peso das exportações de petróleo e minérios no total das exportações.

A não inclusão de variáveis institucionais na modelagem econométrica está baseada em quatro observações importantes. Em primeiro lugar, deve-se ter em mente que não é necessário incluir um indicador institucional no conjunto de variáveis explicativas para avaliar o efeito de mudanças institucionais no investimento. Do ponto de vista conceitual, como foi discutido no Capítulo 2, as informações de uma mudança institucional relevante já estão contidas em outras variáveis consideradas no modelo e que afetam diretamente o comportamento dos agentes: a taxa de juros de empréstimo, o retorno do capital e a oferta de crédito.

Depois, há que se considerar o elevado grau de arbitrariedade empregado para construir as métricas de mudança institucional. Esses índices são definidos de forma direcionada para capturar elementos teóricos de interesse dos pesquisadores, mas, em geral, são apenas aproximações de conceitos abstratos. Um bom exemplo dessa questão é dado pelos indicadores institucionais de liberdade financeira criados por Lora (1997), Morley, Machado e Pettinato (1999), Rodrik (1998) e Santana (2004).

Nos dois primeiros casos, o interesse era medir as reformas econômicas na América Latina. Lora (1997) definiu o grau de reforma financeira de um país como a média simples de quatro indicadores: o primeiro mediu se a taxa de juros de depósitos era determinada livremente; o segundo mediu se a taxa de juros de empréstimos era determinada livremente; o terceiro foi dado pela razão entre reservas e depósitos bancários; e o quarto foi constituído por um índice de qualidade da supervisão bancária e financeira numa escala discreta e subjetiva. Cada indicador foi medido no intervalo entre 0 e 2 . Morley, Machado e Pettinato (1999) definiram o índice de reforma financeira como a média simples de três subíndices com valores entre 0 e 1: existência de controles sobre a 
taxa de empréstimos dos bancos; existência de controles sobre a taxa de remuneração praticada pelos bancos; e existência de controles dos níveis de reserva.

Rodrik (1998), por outro lado, definiu um indicador de liberdade financeira totalmente distinto: uma variável binária que expressou a presença de restrições às transações correntes e de capital em um país (valor 1), ou a ausência (valor 0). Santana (2004) construiu um indicador de liberalização financeira baseado na proposta de Quinn (1997). $\mathrm{O}$ indicador foi definido num intervalo entre 0 e 14 pontos e foi medido em três blocos: o primeiro, indicou a existência de restrições na conta de capital e de termos de compromisso que facilitam o estabelecimento de medidas econômicas mais liberais; o segundo abrangeu as restrições a transações correntes, que incluem transações comerciais e transferências de renda; e o terceiro avaliou as restrições à mobilidade de capitais.

Nenhum desses indicadores pode ser considerado a melhor aproximação do conceito de ambiente institucional. Todos são medidas com elevados graus de erro e que dependem essencialmente da ótica do observador: raramente dois observadores chegam à mesma medida. Exemplo disso é fato de que Santana (2004), utilizando a mesma metodologia e base de informações, não chegou exatamente aos mesmos valores de Quinn (1997), muito embora a correlação entre as duas medidas tenha sido elevada.

O uso dessas variáveis também é bastante limitado por suas características estatísticas. Como visto, algumas são variáveis de distribuição binária, outras não são contínuas e há aquelas que têm domínio limitado (truncado). A combinação, em modelos estatísticos, de indicadores desse tipo com outras variáveis cujas métricas são definidas contabilmente e cujos valores têm elevada variância - valor do crédito concedido, taxas de retorno do capital etc. - resulta em problemas de escala que interferem nos níveis de variância e covariância das séries e, portanto, têm impacto nas inferências. Além disso, os indicadores institucionais podem não ser linearizáveis, dificultando o uso de técnicas econométricas lineares.

Por fim, deve-se destacar que as variáveis institucionais relevantes tendem a ter pouca variação no tempo e elevada variação entre indivíduos em painéis macroeconômicos com $T$ pequeno e $N$ relativamente elevado. Isso porque há grandes distinções institucionais entre os países, ao passo que as mudanças institucionais são lentas e discretas. Esse fato acaba confundindo as medidas institucionais com os efeitos específicos de país empregados na modelagem econométrica de painel. No caso do modelo de efeito fixo, as dummies de país são medidas das diferenças entre indivíduos que são estáveis no tempo - para qualquer valor de $t$, o indivíduo $i$ recebe o valor 1 e os demais, 0 . Esse 
aspecto econométrico possivelmente é o mais importante para explicar porque, na análise de Stasavage (2002), por exemplo, a inclusão das dummies de país nas regressões tornou as variáveis político-institucionais não significativas.

Assim, a análise econométrica deste capítulo baseou-se numa especificação da função investimento que leva em consideração as seguintes variáveis: oferta de crédito, retorno do capital, taxa de juros de longo prazo e preço relativo do capital. A relação descrita pela equação (3.1) traz as variáveis que afetam o investimento definidas nas expressões (2.17) e (2.21) do Capítulo 2.

$$
I_{i t}=f(\mathbf{x})+\varepsilon_{i t}, \varepsilon_{i t}=u_{i}+e_{i t} \text { sendo que } e_{i t} \sim N\left(0, \sigma_{e}^{2}\right),
$$

em que $I_{i t}$ é o investimento no país $i$ e no momento $t$ (em ln), $\mathbf{x}$ é uma matriz formada pelos vetores $x_{i t}$ de variáveis explicativas - crédito (em $\ln$ ), taxa de retorno do capital, taxa de juros de empréstimos de longo prazo e preço relativo do capital -, $u_{i}$ é um efeito específico não observado e $e_{i t}$ é o resíduo, que se supõe que tenha distribuição normal com média zero e variância constante.

Para obter uma estimativa balanceada e com o maior número observações, inicialmente restringiu-se o coeficiente da variável taxa de juros de longo prazo na função investimento (3.1). Essa condição é alterada na seção 3.3, que também analisa os efeitos de outra medida do retorno do capital.

\subsubsection{Base de dados}

A amostra é formada por um painel de 39 países: Austrália, Áustria, Bélgica, Brasil, Bulgária, Canadá, China, Chipre, República Checa, Dinamarca, Estônia, Finlândia, França, Alemanha, Grécia, Hungria, Índia, Indonésia, Irlanda, Itália, Japão, República da Coréia, Látvia, Lituânia, Luxemburgo, Malta, México, Holanda, Polônia, Portugal, Romênia, Rússia, Eslováquia, Eslovênia, Espanha, Suécia, Turquia, Reino Unido, Estados Unidos. Os dados são anuais e referem-se ao período 1995 a 2011, totalizando 663 observações.

A base de dados vem do World Input-Output Database (WIOD), do World Development Indicators on line, do Banco Mundial (WDI), do Banco Central Europeu (European Central Bank, 2014), da base de dados da OCDE Statistics - OECDStat, proveniente de (OECD, 2014) - e do Banco Central do Brasil (2014). A seguir são apresentadas as descrições das séries: 
- Investimento: corresponde a formação bruta de capital fixo em dólares constantes de 1995. A fonte é o WIOD. Áustria, República Checa, Alemanha, Dinamarca, Espanha, Finlândia, França, Reino Unido, Hungria, Irlanda, Itália, Holanda, Polônia e Suécia não dispunham de informações no WIOD para os anos de 2008 e 2009, o mesmo ocorrendo com Chipre e Portugal em 2009. Nesses casos, o banco foi completado com informações do WDI. Isso vale para todos os países da amostra no que diz respeito ás informações relativas aos anos de 2010 e 2011. O deflator implícito do investimento em cada país foi obtido no WIOD e complementado com informações do WDI e do OECDStat.

- Crédito: corresponde ao total de crédito doméstico ao setor privado em dólares constantes de 1995. A fonte é o WDI. Alguns países não dispunham de informações para alguns anos específicos. Nesses casos, foi feito uma média simples entre o ano anterior e o seguinte. ${ }^{18} \mathrm{O}$ crédito foi deflacionado pelo deflator implícito do investimento de cada país.

- Retorno do capital: essa variável foi calculada a partir de duas outras: a remuneração bruta do capital dividida pelo estoque de capital fixo, ambos a preços de 1995. Os dados foram obtidos no WIOD. Alguns países não dispunham de informações sobre o estoque de capital fixo para os anos de 2008 a $2011 .{ }^{19}$ Nesses casos, foi utilizada a técnica do inventário perpétuo para calcular o estoque de capital, que consiste na soma do estoque de capital fixo do ano anterior, descontada a depreciação (de 5\%), com a média do investimento em $t$ e $t-1$. O investimento foi obtido no WDI e no OCDEStat. Austrália, Canadá, Japão, Coréia do Sul, México, Estados Unidos, Índia, Brasil, Turquia e Rússia não dispunham das informações de remuneração do capital em 2010 e 2011. Nesses casos, essa remuneração foi estimada pela diferença entre o PIB e a remuneração do trabalho, cuja evolução entre 2009 e 2011 foi obtida no WDI e OECDStat. A Indonésia e a China não dispunham de informações sobre a evolução dos salários reais. Nesses casos, optou-se por atualizar a remuneração do trabalho pela variação da ocupação e do deflator do PIB.

\footnotetext{
18 Países cujo crédito foi calculado dessa forma: Áustria (ano 1998), Bélgica (ano 1998), Canadá (ano de 2009), França (ano 1998), Luxemburgo (anos 1998 e 1999), Holanda (ano 1998), Romênia (ano 1995) e Eslováquia (ano 2009). No caso do Canadá e da Eslováquia, que não dispunha de dados para os anos de 2009 a 2011, a evolução do crédito foi estimada a partir do crescimento do M3, obtido no banco da OECDStat.

${ }^{19}$ Todos os países tiveram estoque de capital fixo calculado dessa forma nos anos de 2010 e 2011. Alguns países não dispunham de informações também para os anos de 2008 e 2009, são eles: Áustria, Chipre (somente 2009), República Tcheca, Alemanha, Dinamarca, Espanha, Finlândia, França, Inglaterra, Hungria, Irlanda, Itália, Holanda, Polônia, Portugal (somente 2009) e Suécia.
} 
- Retorno esperado do capital: foi definida como a relação entre a parcela esperada pelos capitalistas na distribuição funcional da renda e o estoque de capital. Essa relação mede, portanto, a taxa de retorno esperada do capital. Ela também pode ser entendida como o produto entre a produtividade marginal do capital pela relação capital-PIB. A série foi estimada para os 39 países entre 1995 e 2011 com base nos dados estoque de capital, no PIB e na elasticidade do PIB em relação ao capital obtida por um modelo econométrico de função de produção agregada das economias. As estimativas são apresentadas no Anexo 3.1.

- Taxa de juros de longo prazo: corresponde à taxa de juros nominal de longo prazo em (\%) a.a. Esta é a única variável para a qual o painel não está balanceado. Ao total, há apenas 483 informações, sendo que não há informações para a China, Estônia, Índia, Indonésia e Turquia. As fontes utilizadas para essa série foram: (i) OCDEStat, que dispunha de informações para Austrália, Canadá, República Checa, Dinamarca, Japão, Coreia, México, Estados Unidos e Rússia; (ii) Banco Central Europeu, que dispunha de informações da Áustria, Alemanha, Bélgica, Bulgária, Chipre, Espanha, Finlândia, França, Grécia, Hungria, Irlanda, Itália, Látvia, Lituânia, Luxemburgo, Malta, Holanda, Polônia, Portugal, Eslováquia, Eslovênia, Suécia, Reino Unido e Romênia; e (iii) Banco Central do Brasil (TJLP).

- Preço relativo do capital: corresponde à razão entre o deflator implícito do estoque de capital e o deflator implícito do PIB. Os dados vêm do WIOD, para 1995 a 2009 e do WDI e do OECDStat, para 2010 e $2011^{20}$.

- Taxa real de câmbio: corresponde ao índice da taxa de câmbio real com base 1 em 1995 para todos os países. Os índices nos anos subsequentes são calculados multiplicando o índice do ano anterior pela variação do câmbio nominal (em US\$ por moeda local) e pela variação dos preços locais (deflator implícito do PIB) e dividindo pela variação de preços nos Estados Unidos (deflator implícito do PIB). Os dados vêm do WIOD. Para 2010 e 2011 o deflator do valor adicionado veio do WDI. E do OECDStat.

As variáveis investimento e crédito foram transformadas em logaritmo natural. A Tabela 3.2 traz as estatísticas descritivas do conjunto de variáveis empregadas na análise econométrica.

\footnotetext{
${ }^{20}$ Para os países que não dispunham de informações no WIOD sobre o estoque de capital (ver notas anteriores), o deflator do capital também veio do WDI e do OECDStat.
} 
Tabela 3.2 Estatísticas descritivas das variáveis

\begin{tabular}{lcrrrr}
\hline & Observações & Média & $\begin{array}{r}\text { Erro } \\
\text { padrão }\end{array}$ & Mínimo & Máximo \\
\hline Investimento (In) & 663 & 24,6368 & 1,8958 & 20,4690 & 28,7912 \\
Crédito (In) & 663 & 25,5452 & 2,3155 & 19,5902 & 30,7559 \\
Retorno do capital (\%) & 663 & 0,1231 & $-0,0560$ & 0,0132 & 0,4115 \\
Retorno esperado do capital (\%) & 663 & 0,2574 & 0,0716 & 0,1384 & 0,5504 \\
Taxa de juros de longo prazo & 483 & 0,0571 & 0,0466 & 0,0100 & 0,8738 \\
Preço relativo do capital & 663 & 0,9022 & 0,1440 & 0,4243 & 1,2288 \\
Taxa real de câmbio & 663 & 1,0718 & 0,3371 & 0,4780 & 2,5608 \\
\hline
\end{tabular}

Fonte: WIOD, WDI, OCDEStat, Banco Central Europeu e Banco Central do Brasil.

\subsubsection{Testes de raiz unitária}

Foram aplicados os testes de raiz unitária em painel de Levin, Lin e Chu (2002), Harris e Tzavalis (1999), Breitung (2000), Im, Pesaran e Shin (2003), Maddala e Wu (1999) e Hadri (2000). A metodologia dos testes de raiz unitária é apresentada no Anexo 3.2. Para a aplicação dos testes, optou-se pelas duas especificações com os termos deterministas (modelos 2 e 3), já que, para essas especificações, é possível aplicar todos os testes. As defasagens foram determinadas pelo critério da significância da maior defasagem, partindo do nível máximo de 5 defasagens. Os resultados dos testes são apresentados na Tabela 3.3. Os asteriscos indicam a presença de raiz unitária no nível de significância de 5\%.

Tabela 3.3 Resultados dos Testes de RU

\begin{tabular}{|c|c|c|c|c|c|c|c|c|c|}
\hline & Variáveis & & Investimento & Crédito & $\begin{array}{l}\text { Retorno } \\
\text { do capital }\end{array}$ & $\begin{array}{l}\text { Retorno } \\
\text { esperado } \\
\text { do capital } \\
\end{array}$ & Câmbio & $\begin{array}{c}\text { Preço } \\
\text { Relativo } \\
\text { do capital } \\
\end{array}$ & $\begin{array}{c}\text { Taxa } \\
\text { de juros }\end{array}$ \\
\hline \multirow{8}{*}{$\begin{array}{c}\text { Sem } \\
\text { tendência } \\
\text { (modelo } \\
\text { 2) }\end{array}$} & \multicolumn{2}{|c|}{ Defasagens } & 2 & 3 & 2 & 2 & 4 & 0 & 1 \\
\hline & \multirow{2}{*}{$\begin{array}{c}\text { H0: Todos os } \\
\text { países são } \\
\text { I(1) }\end{array}$} & LLC & $-2,6512$ & $-7,7187$ & $-2,8461$ & $-1,9271$ & 2,2584 * & $-6,9101$ & - \\
\hline & & Breitung & 5,7946 * & 10,1962 * & 1,6644 * & $4,585^{*}$ & 0,8204 * & $7,5686^{*}$ & - \\
\hline & \multirow{4}{*}{$\begin{array}{l}\text { H0: Uma } \\
\text { fração de } \\
\text { países são } \\
\text { I(1) }\end{array}$} & MW- Dfuller & 59,7123 * & 88,3308 * & 106,6071 & 112,7718 & 49,4887 * & 134,184 & 163,3247 \\
\hline & & MW-PPeron & 71,0204 * & 89,0852 * & 118,5088 & 52,4779 * & 42,3229 * & 134,184 & 388,2701 \\
\hline & & IPS & $1,0153^{*}$ & $-0,2884$ * & $-1,0584$ * & 1,354 * & - & $-0,3127$ & $-4,1099$ \\
\hline & & HT & $0,9007^{*}$ & 0,9328 * & 0,9064 * & 0,909 * & 0,9681 * & $0,9007^{*}$ & - \\
\hline & $\begin{array}{l}\text { H0: Todos os } \\
\text { países são } \\
\mathrm{I}(0)\end{array}$ & Hadri & 49,6582 * & 53,9385 * & 48,3399 * & 45,646 * & 44,8576 * & 51,3059 * & - \\
\hline \multirow{8}{*}{$\begin{array}{c}\text { Com } \\
\text { tendência } \\
\text { (modelo } \\
3 \text { ) }\end{array}$} & \multicolumn{2}{|c|}{ Defasagens } & 1 & 3 & 3 & 3 & 4 & 0 & 1 \\
\hline & \multirow{2}{*}{$\begin{array}{c}\text { H0: Todos os } \\
\text { países são } \\
\text { I(1) }\end{array}$} & LLC & $-6,9459$ & $-12,3718$ & $1,1571^{*}$ & 1,9714 * & $-10,8677$ & $-4,5034$ & - \\
\hline & & Breitung & 5,4923 * & 4,9986 * & 1,5029 * & 4,6994 * & 1,8821 * & 3,8954 * & - \\
\hline & \multirow{4}{*}{$\begin{array}{c}\text { Ho: Uma } \\
\text { fração de } \\
\text { países são } \\
\text { I(1) }\end{array}$} & MW- Dfuller & 119,2084 & 248,13 & $97,2647^{*}$ & 49,5567 * & 200,8151 & 121,9225 & 183,0454 \\
\hline & & MW-PPeron & $34, .5437^{*}$ & 47,0386 * & 88,4266 * & 34,9387 * & 36,1069 * & 121,9225 & 232,2704 \\
\hline & & IPS & $-0,7993^{*}$ & $-3,5217$ & $0,2955^{*}$ & 4,0138 * & - & 2,0296 & - \\
\hline & & HT & 0,7998 * & 0,6766 * & 0,6583 * & 0,7638 * & 0,7169 * & 0,6442 * & - \\
\hline & $\begin{array}{c}\text { H0: Todos os } \\
\text { países são } \\
\mathrm{I}(0)\end{array}$ & Hadri & 25,5921 * & 25,1298 * & 23,4469 * & 24,7038 * & 29,3176 * & 26,32 * & - \\
\hline
\end{tabular}

Fonte: Cálculos próprios. Notas: (i) Os resultados com $\left(^{*}\right)$ indicam presença de raiz unitária; (ii) o número de defasagens foi determinado pelo critério de significância da maior defasagem; (iii) a série de taxa de juros é formada por um painel não balanceado, o que não possibilita a execução de todos os testes; (iv) o teste IPS não foi feito para a série de câmbio por insuficiência de dados.

Em geral, os resultados apontam para a presença de uma raiz unitária na maioria das variáveis analisadas. No caso do teste IPS, os resultados indicam a presença de uma 
raiz unitária em todas as variáveis analisadas, exceto o preço relativo do capital e a taxa de juros de longo prazo. O teste LLC, por outro lado, aponta um painel estacionário para todas as variáveis no caso do modelo 2, com exceção da taxa de câmbio. De acordo com o teste de Breitung todas as séries apresentam uma raiz unitária em ambos os mo$\operatorname{delos}(2$ e 3$)$.

Os testes do tipo Fisher, proposto por Madalla e Wu (MW-DFuller e MW- PPeron) apresentaram resultados variados, mas a maioria aponta a presença de uma raiz unitária. O teste de Hadri, cuja hipótese nula é de que o painel estacionário, mostrou a presença de uma raiz unitária para todas as séries analisadas. O painel de taxa de juros de longo prazo teve sua análise comprometida pela falta de dados. Como se trata de um painel não balanceado, não foi possível aplicar todos os testes. Os testes aplicados apontam para a possibilidade de um painel estacionário.

\subsubsection{Testes de cointegração}

Como a maioria dos testes apontou para a presença de uma raiz unitária, pode-se assumir a não estacionariedade do painel e aplicar as técnicas de cointegração para analisar a relação entre as variáveis. Os testes de cointegração aplicados foram os de Kao (1999) e Pedroni (2004), os quais são baseados nos resíduos da regressão de efeito fi$\mathrm{xo}^{21}$. A relação de longo prazo foi estimada por Mínimos Quadrados Ordinário Dinâmi$\cos$ (DOLS). As metodologias dos testes de cointegração são descritas no Anexo 3.3.

Os resultados da regressão de painel com efeito fixo entre investimento, crédito, retorno do capital e preço relativo do capital são apresentados na Tabela A.3.4.1 do Anexo 3.4. Os coeficientes são significativos e têm os sinais esperados. Os resíduos dessa regressão foram utilizados nos testes de cointegração - Tabela 3.4.

Tabela 3.4. Resultados do teste de cointegração, metodologia de Pedroni e Kao

\begin{tabular}{|c|c|c|c|c|c|}
\hline \multicolumn{3}{|c|}{ Metodologia do Pedroni* } & \multicolumn{3}{|c|}{ Metodologia de Kao } \\
\hline Estatística & Valor & $\mathrm{p}$-valor & & estatística & $p$-valor \\
\hline Panel v & $-0,93$ & 0,8231 & $P$ & 184,00 & 0,000 \\
\hline Panel rho & $-10,81$ & 0,0000 & Z & $-3,33$ & 0,000 \\
\hline Panel PP & $-20,97$ & 0,0000 & $L^{*}$ & $-4,75$ & 0,000 \\
\hline Panel ADF & $-11,03$ & 0,0000 & $\mathrm{~d} P \mathrm{Pm}$ & 8,49 & 0,000 \\
\hline Group rho & $-9,88$ & 0,0000 & & & \\
\hline Group PP & $-25,99$ & 0,0000 & & & \\
\hline Group ADF & $-12,57$ & 0,0000 & & & \\
\hline
\end{tabular}

Fonte: Cálculos próprios. Nota: Foi usada 1 defasagem de acordo com o critério de informação de Akaike. Foi considerado o modelo com constante.

\footnotetext{
${ }^{21}$ A metodologia de Westerlund (2007), que é baseada em um vetor de correção de erros, não pôde ser aplicada porque o $T$ é pequeno. O VEC, por conta das defasagens e antecipações, perde muitos graus de liberdade. Neste caso, em que $T=15$, os testes aplicados a relações entre mais de 2 variáveis não convergem por falta de observações.
} 
De acordo com o teste de cointegração de Kao (1999), parece haver uma relação estável de longo prazo entre as quatro variáveis, pois os resíduos da regressão de painel são estacionários. O teste de cointegração de Pedroni $(1999,2004)$ também indicou a possibilidade de uma relação de longo prazo entre as quatro variáveis. Apenas a estatística Panel $v$ sugere que não haja cointegração.

A relação de longo prazo entre as variáveis pode ser estimada por meio de um modelo DOLS (Dynamics Ordinary Least Squares), proposto por Kao e Chiang $(2000)^{22}$. Os resultados das estimativas são apresentados na Tabela 3.5. Observa-se uma relação positiva entre crédito e investimento, da ordem de 0,3476. Como as duas variáveis foram transformadas em logaritmo natural, esse coeficiente indica a elasticidade do investimento em relação ao crédito. O coeficiente associado ao retorno do capital tem o sinal esperado e é estatisticamente significativo a menos de $1 \%$. Seu efeito no investimento é elevado: média dos países da amostra, um aumento de 1 ponto percentual na taxa de retorno do capital eleva em 3,5\% o investimento. O preço relativo do capital apresentou sinal negativo e também bastante significativo.

Tabela 3.5. Relação de Longo Prazo - DOLS

\begin{tabular}{lrrrr}
\hline & Coeficiente & Erro padrão & Z & p-valor \\
\hline Crédito (In) & 0,3476 & 0,0244 & 14,2300 & 0,0000 \\
Retorno do capital & 3,4949 & 0,5178 & 6,7500 & 0,0000 \\
Preço relativo do capital & $-0,9588$ & 0,1399 & $-6,8500$ & 0,0000 \\
\hline$R^{2}$ ajustado & 0,7109 & & & \\
Número de observações & 585 & & & \\
\hline
\end{tabular}

Fonte: Cálculos próprios. Variável dependente: Investimento (ln). Nota: foi incluída uma constante por país.

A elevada significância dos coeficientes e o valor do $\mathrm{R}^{2}$ ajustado relativamente alto indicam que as proposições teóricas traçadas no Capítulo 2, em que se destacou o papel da oferta de crédito, do retorno do capital e dos preços dos ativos sobre o investimento, são válidas nessa amostra de países.

\subsection{Os efeitos do retorno esperado do capital e da taxa de juros de longo prazo}

Esta seção faz uma análise de sensibilidade do modelo de cointegração apresentado na seção anterior, considerando outras variáveis. Ele testa a substituição do retorno efetivo do capital (obtido diretamente das contas sociais dos países da amostra) pelo retorno esperado do capital, o qual foi estimado por um modelo de fronteira estocástica exposto no Anexo 3.1. Essa análise se justifica por dois motivos. Primeiro, deve-se le-

\footnotetext{
22 Segundo Kao e Chiang (2000) o desempenho dos estimadores de DOLS para regressões de painel cointegrado parece superior a dos estimadores de OLS (Ordinary Least Squares) e FMOLS (Fully Modified Ordinary Least Squares).
} 
var em consideração que a análise empírica de séries de tempo realizada para o Brasil no Capítulo 6 não dispõe de informações sobre o retorno efetivo do capital para a maior parte do período analisado (1953 a 2013). Nesse caso, foram empregadas estimativas do retorno esperado do capital. Assim, a presente análise de sensibilidade serve de referência para a comparação com as estimativas feitas apenas com dados do Brasil. Em segundo lugar, as estimativas do retorno esperado do capital retiram do retorno efetivo choques aleatórios que ocorrem devido a fatores imprevisíveis, os quais obviamente não são considerados nas decisões de investimento dos empreendedores.

Outro modelo testado nesta seção é o que incluiu a taxa de juros de longo prazo, variável importante na determinação do investimento conforme visto nos Capítulos $1 \mathrm{e}$ 2. Por fim, é testado a inclusão da taxa real de câmbio, uma variável utilizada na literatura empírica - Le (2004) - para dar conta das variações das taxas de juros em dólares. Nesse caso, manteve-se o retorno efetivo do capital como variável do modelo.

Tabela 3.6. Resultados do teste de cointegração

\begin{tabular}{|c|c|c|c|c|c|}
\hline & \multicolumn{2}{|c|}{ Metodologia do Pedroni* } & \multicolumn{3}{|c|}{ Metodologia de Kao } \\
\hline Estatística & Valor & p-valor & & estatística & p-valor \\
\hline \multicolumn{6}{|c|}{ Relação entre investimento, retorno esperado do capital e preço relativo do capital } \\
\hline Panel v & 1,59 & 0,0556 & $\mathrm{P}$ & 163,70 & 0,0000 \\
\hline Panel rho & $-18,84$ & 0,0000 & z & $-3,29$ & 0,0005 \\
\hline Panel PP & $-23,78$ & 0,0000 & $L^{*}$ & $-3,83$ & 0,0001 \\
\hline Panel ADF & $-11,88$ & 0,0000 & ed Pm & 6,86 & 0,0000 \\
\hline Group rho & $-18,06$ & 0,0000 & & & \\
\hline Group PP & $-28,74$ & 0,0000 & & & \\
\hline Group ADF & $-13,49$ & 0,0000 & & & \\
\hline \multicolumn{6}{|c|}{ Relação entre investimento, retorno do capital, preço relativo do capital e taxa de juros } \\
\hline Panel v & 2,09 & 0,0185 & $P$ & 92,21 & 0,0270 \\
\hline Panel rho & $-7,88$ & 0,0000 & z & $-0,76$ & 0,2249 \\
\hline Panel PP & $-15,67$ & 0,0000 & $L^{*}$ & $-0,79$ & 0,2151 \\
\hline Panel ADF & $-2,64$ & 0,0041 & ed Pm & 2,08 & 0,0189 \\
\hline Group rho & $-5,52$ & 0,0000 & & & \\
\hline Group PP & $-15,15$ & 0,0000 & & & \\
\hline Group ADF & 0,22 & 0,5852 & & & \\
\hline \multicolumn{6}{|c|}{ Relação entre investimento, retorno do capital, preço relativo do capita, taxa de juros e taxa real de câmbio } \\
\hline Panel v & $-1,14$ & 0,8727 & $\mathrm{P}$ & 91,66 & 0,0295 \\
\hline Panel rho & $-5,49$ & 0,0000 & z & $-0,68$ & 0,2467 \\
\hline Panel PP & $-13,65$ & 0,0000 & $L^{*}$ & $-0,73$ & 0,2340 \\
\hline Panel ADF & $-1,25$ & 0,1051 & ed Pm & 2,03 & 0,0213 \\
\hline Group rho & $-3,07$ & 0,0011 & & & \\
\hline Group PP & $-12,21$ & 0,0000 & & & \\
\hline Group ADF & 2,51 & 0,9940 & & & \\
\hline
\end{tabular}

Fonte: Cálculos próprios. Nota: Foi usada 1 defasagem de acordo com o critério de informação de Akaike. Foi considerado o modelo com constante.

A Tabela 3.6 traz o teste de cointegração para três casos analisados: (i) crédito, retorno esperado do capital e preço relativo do capital; (ii) crédito, retorno efetivo do capital, preço relativo do capital e taxa de juros de longo prazo; e (iii) crédito, retorno efetivo do capital, preço relativo do capital, taxa de juros de longo prazo e taxa real de 
câmbio. As Tabelas A.3.4.2 a A.3.4.4 do Anexo 3.4 trazem as regressões por efeito fixo dos três modelos que estimam os resíduos empregados nos testes de cointegração. Notase que parece haver relações estáveis de longo prazo nos três modelos. No segundo e terceiro, há uma ligeira perda de significância nos testes porque a amostra é menor que a empregada no teste da seção anterior.

A Tabela 3.7 traz os coeficientes estimados nos três modelos. Observa-se que, no primeiro caso, a substituição do retorno efetivo pelo retorno esperado do capital provoca mudanças nos coeficientes estimados. Os coeficientes associados ao crédito e ao preço relativo do capital são ligeiramente maiores (em módulo) do que os apresentados no modelo básico. Já o coeficiente associado ao retorno esperado é um pouco menor que o estimado para o retorno efetivo do capital.

Tabela 3.7. Relação de Longo Prazo - DOLS

\begin{tabular}{|c|c|c|c|c|}
\hline & Coeficiente & Erro padrão & Z & p-valor \\
\hline \multicolumn{5}{|c|}{ Relação entre investimento, produtividade marginal do capital e preço relativo do capital } \\
\hline Crédito (In) & 0,3632 & 0,0241 & 15,0700 & 0,0000 \\
\hline Preço relativo do capital & $-1,0749$ & 0,1429 & $-7,5200$ & 0,0000 \\
\hline $\mathrm{R}^{2}$ ajustado & 0,7177 & & & \\
\hline Crédito (In) & 0,1639 & 0,0382 & 4,2900 & 0,0000 \\
\hline Retorno efetivo do capital & 2,4526 & 0,8352 & 2,9400 & 0,0030 \\
\hline Preço relativo do capital & $-1,2333$ & 0,1584 & $-7,7900$ & 0,0000 \\
\hline Taxa de juros de longo prazo & $-5,4575$ & 0,4132 & $-13,2100$ & 0,0000 \\
\hline Crédito (In) & 0,0839 & 0,0366 & 2,2900 & 0,0220 \\
\hline Retorno efetivo do capital & 3,0351 & 0,8139 & 3,7300 & 0,0000 \\
\hline Preço relativo do capital & $-1,0725$ & 0,1527 & $-7,0200$ & 0,0000 \\
\hline Taxa de juros de longo prazo & $-5,3669$ & 0,4102 & $-13,0800$ & 0,0000 \\
\hline Taxa de câmbio & 0,3400 & 0,0591 & 5,7500 & 0,0000 \\
\hline $\mathrm{R}^{2}$ ajustado & 0,7834 & & & \\
\hline Número de observações: & 300 & & & \\
\hline
\end{tabular}

No segundo caso, observou-se uma relação negativa e bastante significativa entre investimento e taxa de juros de longo prazo. Um aumento de 1 ponto percentual na taxa de juros de longo prazo diminui em 5,5\% o investimento na média dos países da amostra. A inclusão dessa variável diminuiu de forma expressiva o efeito da oferta de crédito no investimento - o coeficiente associado ao crédito caiu de 0,3476 para 0,1639 . Os coeficientes associados às demais variáveis também variaram consideravelmente. No terceiro caso, o coeficiente associado à taxa real de câmbio é positivo e estatisticamente significativo. Como essa taxa é medida em dólares por moeda local, uma valorização da 
moeda nacional frente ao dólar norte-americano eleva o investimento. O coeficiente associado ao crédito diminui, mas ainda apresentou-se significativo a 5\%.

\subsection{Efeitos dos determinantes do investimento na acumulação de capital e no crescimento econômico}

As equações (2.23) a (2.28) do Capítulo 2 definiram a contabilidade do crescimento, a função investimento e os efeitos parciais das variáveis determinantes do investimento sobre a evolução no tempo das taxas de acumulação de capital e de crescimento econômico de um país. A Tabela 3.8 traz a decomposição do crescimento econômico de 39 países entre 1995 e 2011.

Tabela 3.8. Decomposição do crescimento do PIB, por país, 1995 a 2011 (\% ao ano)

\begin{tabular}{|c|c|c|c|c|}
\hline País & $g_{Y}$ & $g_{A^{*}}$ & $s_{k} \cdot g_{K}$ & $S_{N} \cdot g_{N}$ \\
\hline Austrália & $3,25 \%$ & $0,41 \%$ & $1,63 \%$ & $1,21 \%$ \\
\hline Áustria & $2,05 \%$ & $0,73 \%$ & $0,71 \%$ & $0,61 \%$ \\
\hline Bélgica & $1,81 \%$ & $0,23 \%$ & $0,93 \%$ & $0,66 \%$ \\
\hline Bulgária & $1,76 \%$ & $0,78 \%$ & $1,03 \%$ & $-0,05 \%$ \\
\hline Brasil & $3,18 \%$ & $0,00 \%$ & $1,96 \%$ & $1,22 \%$ \\
\hline Canadá & $3,19 \%$ & $1,00 \%$ & $1,25 \%$ & $0,93 \%$ \\
\hline China & $9,89 \%$ & $5,83 \%$ & $3,54 \%$ & $0,52 \%$ \\
\hline Chipre & $2,98 \%$ & $1,05 \%$ & $0,78 \%$ & $1,15 \%$ \\
\hline República Checa & $2,56 \%$ & $1,30 \%$ & $1,26 \%$ & $0,00 \%$ \\
\hline Alemanha & $1,44 \%$ & $0,28 \%$ & $0,69 \%$ & $0,46 \%$ \\
\hline Dinamarca & $1,33 \%$ & $0,22 \%$ & $0,81 \%$ & $0,30 \%$ \\
\hline Espanha & $2,51 \%$ & $-0,02 \%$ & $1,37 \%$ & $1,17 \%$ \\
\hline Estônia & $4,90 \%$ & $2,46 \%$ & $2,54 \%$ & $-0,10 \%$ \\
\hline Finlândia & $2,77 \%$ & $1,15 \%$ & $0,82 \%$ & $0,80 \%$ \\
\hline França & $1,75 \%$ & $0,83 \%$ & $0,45 \%$ & $0,47 \%$ \\
\hline Reino Unido & $2,03 \%$ & $0,23 \%$ & $1,11 \%$ & $0,70 \%$ \\
\hline Grécia & $2,01 \%$ & $-0,68 \%$ & $1,88 \%$ & $0,81 \%$ \\
\hline Hungria & $2,34 \%$ & $1,69 \%$ & $0,65 \%$ & $0,00 \%$ \\
\hline Indonésia & $3,84 \%$ & $1,34 \%$ & $1,67 \%$ & $0,83 \%$ \\
\hline Índia & $7,47 \%$ & $2,87 \%$ & $3,85 \%$ & $0,75 \%$ \\
\hline Irlanda & $4,72 \%$ & $0,13 \%$ & $3,16 \%$ & $1,42 \%$ \\
\hline Itália & $0,77 \%$ & $-0,45 \%$ & $0,65 \%$ & $0,57 \%$ \\
\hline Japão & $0,73 \%$ & $1,24 \%$ & $0,02 \%$ & $-0,53 \%$ \\
\hline República da Coréia & $5,09 \%$ & $3,17 \%$ & $1,12 \%$ & $0,80 \%$ \\
\hline Lituânia & $4,50 \%$ & $2,24 \%$ & $2,40 \%$ & $-0,15 \%$ \\
\hline Luxemburgo & $3,84 \%$ & $0,56 \%$ & $1,32 \%$ & $1,96 \%$ \\
\hline Látvia & $4,46 \%$ & $2,26 \%$ & $2,60 \%$ & $-0,40 \%$ \\
\hline México & $2,81 \%$ & $1,89 \%$ & $-0,07 \%$ & $0,99 \%$ \\
\hline Malta & $2,72 \%$ & $0,85 \%$ & $1,03 \%$ & $0,85 \%$ \\
\hline Holanda & $2,20 \%$ & $0,48 \%$ & $0,82 \%$ & $0,90 \%$ \\
\hline Polônia & $4,23 \%$ & $2,84 \%$ & $1,08 \%$ & $0,30 \%$ \\
\hline Portugal & $1,86 \%$ & $-0,31 \%$ & $1,75 \%$ & $0,43 \%$ \\
\hline Romênia & $2,36 \%$ & $0,75 \%$ & $1,15 \%$ & $0,47 \%$ \\
\hline Rússia & $3,22 \%$ & $1,68 \%$ & $1,48 \%$ & $0,06 \%$ \\
\hline Eslováquia & $4,34 \%$ & $1,94 \%$ & $2,23 \%$ & $0,17 \%$ \\
\hline Eslovênia & $3,13 \%$ & $1,78 \%$ & $1,27 \%$ & $0,08 \%$ \\
\hline Suécia & $2,66 \%$ & $0,97 \%$ & $1,25 \%$ & $0,43 \%$ \\
\hline Turquia & $5,28 \%$ & $2,26 \%$ & $2,62 \%$ & $0,40 \%$ \\
\hline Estados Unidos & $2,63 \%$ & $0,85 \%$ & $1,47 \%$ & $0,31 \%$ \\
\hline
\end{tabular}

Fonte: WIOD, WDI, OCDEStat. Cálculos próprios. (*) Para simplificar a exposição dos resultados, a taxa $g_{A}$ inclui a variação na ineficiência $u$ definida nas equações do Capítulo 2 . 
Observa-se que todos os países tiveram taxas médias de crescimento do PIB positivas entre 1995 e 2011. Alguns cresceram pouco, abaixo de 1\% ao ano como Itália e Japão, e outros cresceram muito, como a China ( $9,9 \%$ ao ano). Em cada caso, o crescimento foi impulsionado por diferentes variáveis. A maioria dos países teve seu crescimento impulsionado pela acumulação de capital, como por exemplo, Austrália, Brasil e Espanha. Há outros países que tiveram seu crescimento impulsionado pelo aumento da produtividade - o caso da China, Finlândia, França, Japão e República Checa, entre outros. É importante observar que o padrão de crescimento foi diferente nos dois subperíodos (1995 a 2003 e 2003 a 2011), algo que é sumariado nos dados da Tabela 3.9.

Tabela 3.9. Variação das taxas de crescimento por país, 1995 a 2003 contra 2003 a 2011 , pontos percentuais

\begin{tabular}{|c|c|c|c|c|}
\hline País & $d g_{Y} / d t$ & $d g_{A} / d t$ & $s_{K}{ }^{*} d g_{K} / d t$ & $s_{L}{ }^{*} d g_{L} / d t$ \\
\hline Austrália & $-1,09$ p.p. & $-3,77$ p.p. & 2,44 p.p. & 0,24 p.p. \\
\hline Áustria & $-0,42$ p.p. & $-0,39$ p.p. & $-0,11$ p.p. & 0,08 p.p. \\
\hline Bélgica & $-0,55$ p.p. & $-0,55$ p.p. & $-0,11$ p.p. & 0,12 p.p. \\
\hline Bulgária & 1,93 p.p. & $-0,20$ p.p. & 1,47 p.p. & 0,66 p.p. \\
\hline Brasil & 1,73 p.p. & $-0,18$ p.p. & 1,17 p.p. & 0,74 p.p. \\
\hline Canadá & $-0,51$ p.p. & $-0,17$ p.p. & 0,08 p.p. & $-0,42$ p.p. \\
\hline China & 2,15 p.p. & -1,05 p.p. & 3,35 p.p. & $-0,15$ p.p. \\
\hline Chipre & -0,76 p.p. & $-1,13$ p.p. & 0,26 p.p. & 0,10 p.p. \\
\hline República Checa & 1,54 p.p. & 0,80 p.p. & 0,08 p.p. & 0,66 p.p. \\
\hline Alemanha & 0,10 p.p. & $-0,07$ p.p. & $-0,24$ p.p. & 0,42 p.p. \\
\hline Dinamarca & -1,33 p.p. & -1,21 p.p. & 0,32 p.p. & $-0,43$ p.p. \\
\hline Espanha & $-2,13$ p.p. & 0,03 p.p. & $-0,07$ p.p. & $-2,09$ p.p. \\
\hline Estônia & $-4,05$ p.p. & $-4,69$ p.p. & $-0,12$ p.p. & 0,75 p.p. \\
\hline Finlândia & $-1,82$ p.p. & $-1,15$ p.p. & $-0,07$ p.p. & $-0,60$ p.p. \\
\hline França & $-0,85$ p.p. & $-0,05$ p.p. & $-0,23$ p.p. & $-0,56$ p.p. \\
\hline Reino Unido & $-1,81$ p.p. & $-1,70$ p.p. & $-0,08$ p.p. & $-0,03$ p.p. \\
\hline Grécia & $-3,38$ p.p. & $-3,23$ p.p. & $-0,90$ p.p. & 0,75 p.p. \\
\hline Hungria & -2,78 p.p. & -2,85 p.p. & 0,81 p.p. & $-0,74$ p.p. \\
\hline Indonésia & 4,45 p.p. & 2,46 p.p. & 1,33 p.p. & 0,66 p.p. \\
\hline Índia & 2,76 p.p. & 1,33 p.p. & 2,15 p.p. & $-0,72$ p.p. \\
\hline Irlanda & $-6,01$ p.p. & $-3,27$ p.p. & $-0,54$ p.p. & -2,20 p.p. \\
\hline Itália & $-1,18$ p.p. & $-0,50$ p.p. & $-0,19$ p.p. & $-0,49$ p.p. \\
\hline Japão & $-0,16$ p.p. & $-0,07$ p.p. & 0,18 p.p. & $-0,27$ p.p. \\
\hline República da Coréia & $-0,65$ p.p. & $-0,53$ p.p. & $-0,19$ p.p. & 0,07 p.p. \\
\hline Lituânia & $-2,50$ p.p. & $-2,63$ p.p. & $-0,07$ p.p. & 0,20 p.p. \\
\hline Luxemburgo & -1,59 p.p. & -1,18 p.p. & 0,10 p.p. & $-0,51$ p.p. \\
\hline Látvia & $-3,01$ p.p. & $-2,10$ p.p. & 0,31 p.p. & -1,23 p.p. \\
\hline México & $-1,15$ p.p. & $-2,56$ p.p. & 1,65 p.p. & $-0,24$ p.p. \\
\hline Malta & $-0,22$ p.p. & 0,08 p.p. & $-0,78$ p.p. & 0,49 p.p. \\
\hline Holanda & -1,05 p.p. & $-0,26$ p.p. & $-0,01$ p.p. & $-0,78$ p.p. \\
\hline Polônia & 0,62 p.p. & $-2,20$ p.p. & 0,92 p.p. & 1,90 p.p. \\
\hline Portugal & $-1,60$ p.p. & 0,60 p.p. & -1,03 p.p. & $-1,18$ p.p. \\
\hline Romênia & 2,34 p.p. & 0,48 p.p. & 1,03 p.p. & 0,83 p.p. \\
\hline Rússia & 2,31 p.p. & 0,82 p.p. & 1,50 p.p. & $-0,01$ p.p. \\
\hline Eslováquia & 1,23 p.p. & 0,94 p.p. & $-0,25$ p.p. & 0,55 p.p. \\
\hline Eslovênia & $-1,70$ p.p. & $-0,95$ p.p. & $-0,87$ p.p. & 0,13 p.p. \\
\hline Suécia & -0,78 p.p. & $-0,88$ p.p. & 0,12 p.p. & $-0,02$ p.p. \\
\hline Turquia & 1,97 p.p. & 0,68 p.p. & 0,80 p.p. & 0,49 p.p. \\
\hline Estados Unidos & -1,86 p.p. & $-0,98$ p.p. & $-0,28$ p.p. & -0,59 p.p. \\
\hline
\end{tabular}

Fonte: WIOD, WDI, OCDEStat. Cálculos próprios. As Tabelas A.3.5.1 e A.3.5.2 do Anexo 3.5 trazem a decomposição do crescimento para dois subperíodos distintos - 1995 a 2003 e 2003 a 2011. 
A maioria dos países teve variação negativa da taxa média anual de crescimento de um subperíodo para o outro, com variação também negativa do crescimento da produtividade. A Indonésia foi o país que apresentou a maior variação da taxa média anual de crescimento, de 4,5 pontos percentuais entre os dois subperíodos, com variação positiva da taxa média de aumento da produtividade (2,5 pontos percentuais) e da taxa média de acumulação de capital (1,3 ponto percentual). Em alguns países como a Índia, a Romênia, a Rússia e o Brasil, os aumentos nas taxas de acumulação de capital foram importantes para elevar as taxas médias anuais de crescimento do PIB entre os dois subperíodos.

A Tabela 3.10 traz os efeitos parciais das variações, entre 1995-2003 e 2003-2011, da taxa de crescimento do crédito, da taxa média de retorno do capital e dos preços relativos do capital sobre a variação da taxa de crescimento do estoque de capital para os países da amostra. Esse efeito foi calculado empregando-se os coeficientes estimados na seção 3.2.3, Tabela 3.6, na expressão (2.27). O efeito conjunto das evoluções das três variáveis sobre a taxa média anual de acumulação é apresentado na última coluna da Tabela 3.10.

Entre os subperíodos, 1995-2003 e 2003-2011, houve expansão de crédito em todos os países, o que teve uma contribuição positiva na taxa de acumulação de capital. O efeito do retorno de capital foi variado: positivo para os países que tiveram recuperação da taxa de retorno do capital (china em particular) e negativo, para as economias em que houve redução do retorno médio nos subperíodos - esse foi o caso de, por exemplo, de Irlanda e Portugal. Em poucos países, a evolução do preço relativo do capital afetou negativamente a taxa de acumulação de capital (Indonésia, por exemplo). O balanço da evolução do crédito, do retorno do capital e do preço relativo do capital afetou negativamente apenas 7 dos 39 países analisados, sendo que na média da amostra, o efeito foi de 1,26 ponto percentual a mais de taxa de acumulação de capital.

A Tabela A.3.5.3 do Anexo 3.5 traz a comparação entre a variação observada nas taxas de acumulação de capital entre os dois subperíodos e os efeitos conjuntos sobre a variação da taxa de acumulação de capital do crescimento do crédito e das variações nas taxas médias de retorno do capital e do preço relativo do capital. No geral, as evoluções dessas três variáveis indicam corretamente o sinal e a magnitude da variação efetivamente observada na taxa de acumulação de capital entre os subperíodos 1995-2003 e 2003-2011. As maiores diferenças entre as variações observadas e previstas ocorreram na China, Eslovênia e Polônia. Na China houve uma aceleração da acumulação de capital muito maior do que o explicado pela evolução conjunta dessas três variáveis. Na Eslovênia e na Polônia, houve uma desaceleração maior do que a esperado. 
Tabela 3.10. Efeitos parciais sobre a taxa média anual de acumulação de capital, por país, 1995 a 2003 contra 2003 a 2011, pontos percentuais

\begin{tabular}{|c|c|c|c|c|}
\hline País & Crédito & $\begin{array}{r}\text { Retorno de } \\
\text { capital } \\
\end{array}$ & $\begin{array}{r}\text { Preço relativo } \\
\text { do capital } \\
\end{array}$ & Conjunto \\
\hline Austrália & 0,31 p.p. & $-0,22$ p.p. & 5,48 p.p. & 4,38 p.p. \\
\hline Áustria & 0,09 p.p. & 0,11 p.p. & 0,81 p.p. & 0,88 p.p. \\
\hline Bélgica & 0,11 p.p. & $-0,15$ p.p. & 0,17 p.p. & $-0,05$ p.p. \\
\hline Bulgária & 0,49 p.p. & $-0,07$ p.p. & 0,53 p.p. & 0,64 p.p. \\
\hline Brasil & 0,58 p.p. & $-0,70$ p.p. & 2,69 p.p. & 1,92 p.p. \\
\hline Canadá & 0,04 p.p. & $-0,03$ p.p. & $-0,47$ p.p. & $-0,69$ p.p. \\
\hline China & 1,21 p.p. & 16,84 p.p. & -1,15 p.p. & 13,93 p.p. \\
\hline Chipre & 0,17 p.p. & $-0,01$ p.p. & $-0,10$ p.p. & $-0,11$ p.p. \\
\hline República Checa & 0,39 p.p. & $-0,17$ p.p. & 1,77 p.p. & 1,66 p.p. \\
\hline Alemanha & 0,00 p.p. & 0,05 p.p. & 0,90 p.p. & 0,84 p.p. \\
\hline Dinamarca & 0,15 p.p. & $-0,38$ p.p. & 2,44 p.p. & 1,92 p.p. \\
\hline Espanha & 0,30 p.p. & 0,04 p.p. & 0,26 p.p. & 0,29 p.p. \\
\hline Estônia & 0,45 p.p. & $-0,58$ p.p. & 2,02 p.p. & 1,04 p.p. \\
\hline Finlândia & 0,19 p.p. & 0,03 p.p. & 0,18 p.p. & 0,22 p.p. \\
\hline França & 0,09 p.p. & $-0,06$ p.p. & $-0,08$ p.p. & $-0,10$ p.p. \\
\hline Reino Unido & 0,16 p.p. & $-0,69$ p.p. & 1,70 p.p. & 0,82 p.p. \\
\hline Grécia & 0,24 p.p. & $-0,61$ p.p. & 0,58 p.p. & $-0,07$ p.p. \\
\hline Hungria & 0,20 p.p. & $-0,32$ p.p. & 2,16 p.p. & 1,81 p.p. \\
\hline Indonésia & 0,44 p.p. & 2,02 p.p. & -1,95 p.p. & $-0,02$ p.p. \\
\hline Índia & 1,15 p.p. & 1,47 p.p. & 0,22 p.p. & 0,77 p.p. \\
\hline Irlanda & 0,48 p.p. & $-2,02$ p.p. & 2,99 p.p. & 0,39 p.p. \\
\hline Itália & 0,12 p.p. & $-0,26$ p.p. & 0,72 p.p. & 0,47 p.p. \\
\hline Japão & 0,00 p.p. & 0,47 p.p. & $-0,18$ p.p. & 0,27 p.p. \\
\hline República da Coréia & 0,26 p.p. & 0,55 p.p. & $-0,93$ p.p. & $-0,51$ p.p. \\
\hline Lituânia & 0,57 p.p. & $-0,01$ p.p. & 1,40 p.p. & 1,39 p.p. \\
\hline Luxemburgo & 0,30 p.p. & 0,42 p.p. & 1,29 p.p. & 1,74 p.p. \\
\hline Látvia & 0,61 p.p. & $-0,50$ p.p. & 0,91 p.p. & 0,18 p.p. \\
\hline México & 0,23 p.p. & 1,41 p.p. & 0,62 p.p. & 2,17 p.p. \\
\hline Malta & 0,15 p.p. & $-0,14$ p.p. & $-0,34$ p.p. & $-0,45$ p.p. \\
\hline Holanda & 0,15 p.p. & 0,22 p.p. & 1,11 p.p. & 1,29 p.p. \\
\hline Polônia & 0,44 p.p. & 2,54 p.p. & 0,78 p.p. & 3,42 p.p. \\
\hline Portugal & 0,20 p.p. & $-0,93$ p.p. & 0,87 p.p. & $-0,24$ p.p. \\
\hline Romênia & 0,74 p.p. & $-0,07$ p.p. & 0,87 p.p. & 1,04 p.p. \\
\hline Rússia & 0,61 p.p. & 1,10 p.p. & 0,54 p.p. & 1,63 p.p. \\
\hline Eslováquia & 0,27 p.p. & 0,71 p.p. & 0,62 p.p. & 1,30 p.p. \\
\hline Eslovênia & 0,59 p.p. & $-0,14$ p.p. & 0,99 p.p. & 1,04 p.p. \\
\hline Suécia & 0,23 p.p. & -0,62 p.p. & 0,89 p.p. & 0,11 p.p. \\
\hline Turquia & 1,16 p.p. & 2,36 p.p. & $-0,24$ p.p. & 2,63 p.p. \\
\hline Estados Unidos & 0,08 p.p. & 0,01 p.p. & 1,61 p.p. & 1,35 p.p. \\
\hline
\end{tabular}

Fonte: WIOD e WDI, cálculos próprios.

O impacto das variações nessas três variáveis sobre a taxa de crescimento econômico dos países é dado pelo efeito dessas dinâmicas sobre a taxa de acumulação de capital e pela participação do capital na renda. Essas estimativas são apresentadas na Tabela A.3.5.4 do anexo. Para a maior parte dos países esse efeito foi positivo, sendo particularmente elevado no caso da China, México, Polônia e Turquia. No caso do Brasil, os aumentos da oferta de crédito e da taxa retorno do capital e a redução do preço relativo do capital indicaram uma expansão de mais de 0,5 ponto percentual na taxa de crescimento econômico entre os subperíodos 1995-2003 e 2003-2011. 
Parte 2.

Mudanças institucionais, crédito, investimento e crescimento no Brasil 


\section{Capítulo 4}

\section{Uma abordagem histórica do financiamento do investimento no Brasil}

Na segunda metade do século XIX e ao longo do século XX, o desenvolvimento institucional da economia brasileira estabeleceu os principais mecanismos de financiamento do investimento privado no país: o mercado acionário, o crédito hipotecário e o crédito de longo prazo com apoio e fomento governamental. Essas formas de financiamento do investimento tiveram importância relativa bastante variada ao longo da história e passaram por aprimoramentos ao longo do tempo. Esses mecanismos foram revitalizados após a estabilização da economia, na segunda metade da década de 1990, e foram responsáveis pelo avanço do investimento de 2004 em diante.

Este capítulo analisa a constituição desses mecanismos e suas principais alterações ao longo da história econômica brasileira, da segunda metade do século XIX, quando são formadas a base do financiamento de longo prazo no país, até o final dos anos 1980, período de crise profunda e desarticulação do financiamento. A análise começa na economia cafeeira e nos primórdios da industrialização brasileira, quando foram constituídos o crédito hipotecário e o mercado acionário - este último, muito importante para o financiamento da infraestrutura ferroviária. Depois é analisada a implantação do Banco Nacional de Desenvolvimento Econômico (BNDE) com a finalidade de financiar o capital de longo prazo. Por fim, são avaliadas as reformas institucionais dos anos 1960 e seu impacto sobre a intermediação financeira e o investimento.

\subsection{Crédito hipotecário e mercado de ações}

\subsubsection{O financiamento da economia cafeeira e o início da industrialização}

Os dois principais mecanismos de financiamento ao investimento produtivo que prevaleceram no Brasil durante a expansão da economia cafeeira e o início da industrialização foram o crédito hipotecário e o mercado de ações. Nesses instrumentos, fundou-se a expansão da atividade agrícola, da infraestrutura de transportes e energia e, posteriormente, o financiamento do capital industrial.

Em meados do século XIX, como aponta Marcondes (2011), houve mudanças institucionais que beneficiaram o crédito hipotecário no Brasil. Essas mudanças iniciaram com a criação do registro geral de hipotecas na Lei Orçamentária de 1843, regulamentada por Decreto apenas em 1846, que estabeleceu a inscrição concentrada na comarca onde se situa- 
vam os bens hipotecados. Outra medida que deu maior garantia aos credores foi a reforma hipotecária de 1864, regulamentada em 1865. Essa lei ampliou a publicidade das hipotecas por meio de um registro geral e da inscrição das transmissões e dos ônus reais das propriedades suscetíveis de hipoteca ${ }^{23}$.

Essas mudanças institucionais e a expansão da produção cafeeira levaram ao crescimento da demanda por crédito. Para atender a essa expansão, foi instituído em 1875 um decreto que procurava incentivar bancos hipotecários. Contudo, segundo Marcondes (2011), a demora na instalação de tais bancos salientou os problemas levantados no Congresso Agrícola ${ }^{24}$, especialmente as dificuldades de atração dos capitais e de cobrança das dívidas. A solução proposta no Congresso foi permitir a emissão de moeda por estas instituições de crédito agrícola para financiar a lavoura.

Em 1886, o Banco do Brasil criou sua carteira hipotecária para suprir crédito rural a juros baixos. No entanto, esse crédito não era suficiente para atender a demanda que se elevava com as crises internacionais e com a adoção da mão de obra assalariada. Segundo Sochaczewski (1993), na medida em que o sistema econômico se tornava mais complexo, os fazendeiros enfrentavam crescentes dificuldades pela falta de crédito. ${ }^{25}$

Para enfrentar as dificuldades, a região onde se concentrava a maior parte da produção cafeeira buscou soluções próprias. Em 1909, foi fundado o Banco de Crédito Hipotecário e Agrícola de São Paulo, que nasceu da concessão do Governo do Estado de São Paulo para uma sociedade de crédito hipotecário à atividade econômica, em especial à agricultura. O banco foi concedido a uma sociedade francesa que o organizou e o manteve até 1926, quando foi encampado pelo próprio Governo do Estado.

Outro importante instrumento de financiamento ao investimento produtivo no Brasil durante a expansão agrícola do final do século XIX foi o mercado acionário. Segundo Hanley (2001), no auge da expansão cafeeira, pelo menos 23 companhias levantaram fundos com a venda de cerca de 450 mil ações em 1886, que representaram US\$ 35 milhões. Além disso, o emprego da sociedade anônima para a organização de negócios ajudou São Paulo a

\footnotetext{
${ }^{23}$ Foram definidos os objetos utilizados como hipoteca: os imóveis e seus respectivos acessórios e, no caso agrícola, escravos e animais. Além disso, o novo registro passou a especificar as características do colateral e do crédito (valor, prazo e juros). Com isso, era possível conhecer o comprometimento do imóvel com o crédito e a possibilidade de novas hipotecas a partir daquela garantia.

${ }^{24}$ Evento organizado pelo governo imperial e realizado na cidade do Rio de Janeiro em julho de 1878. Reuniu agricultores das principais regiões brasileiras produtoras de café: Minas Gerais, Rio de Janeiro, São Paulo e Espírito Santo. O objetivo da convocação de um Congresso Agrícola foi encontrar formas de auxiliar a lavoura "do país" e impulsionar seu desenvolvimento.

${ }^{25}$ Para explicar essa escassez de crédito rural, o autor levantou duas hipóteses: (i) as atividades rurais não ofereciam suficientes garantias para empréstimos, preferindo os bancos operar com o setor comercial e (ii) a permanente situação de aperto do crédito enfrentada pelos produtores favoreceu uma política oligopolista dos exportadores de café e dos bancos a eles ligados.
} 
fundar um setor bancário regional e a levantar capital para o amplo sistema de ferrovias que acompanhavam a fronteira agrícola do Estado e aceleravam o surto cafeeiro.

A primeira bolsa de valores no Estado de São Paulo foi organizada em 1890 como resultado das mudanças legislativas implantadas com a República ${ }^{26}$. A despeito do início conturbado $^{27}$, observou-se um crescimento impressionante do número de ações entre a última década do século XIX e meados da primeira década do século XX. Em 1905, o número de ações em mãos de investidores chegou a 1,2 milhões, valor mais de duas vezes superior ao de 1886 (449,5 mil). Isso ocorreu, segundo Hanley (2001), porque os bancos fundados a partir de 1890 eram significativamente maiores do que aqueles que operavam na década de 1880. Além disso, as empresas ferroviárias (Paulista e Mogiana) sofreram expansões notáveis e as empresas industriais que entraram na bolsa no início do século XX eram bem maiores.

É importante destacar que antes de 1890, em sua maioria, as emissões de títulos eram ligadas às empresas de serviços e infraestrutura ${ }^{28}$, que acompanhavam a expansão do setor cafeeiro. Depois dessa data, as empresas industriais e de construção imobiliária começaram a recorrer ao mercado de ações para seu financiamento. Segundo Hanley (2001), o primeiro título emitido por uma empresa que não pertencia ao setor de infraestrutura da época foi a Companhia Industrial de São Paulo, uma empresa industrial que trabalhava com produtos têxteis, gráfica e fósforo.

A partir de 1905, o rápido crescimento no número e nos tipos de ações e títulos negociados na Bolsa continuou. Esse foi um fenômeno regional de São Paulo que contribuiu para a modernização e desenvolvimento da economia paulista. Segundo Hanley (2001), o número de empresas financiadas pela venda de ações na Bolsa de São Paulo aumentou em $25 \%$ entre 1905 e 1906. Também se observou um crescimento notável na formação de sociedades anônimas. Em meados da década de 1910, quase metade das 41 empresas têxteis paulistas era financiada por meio da venda de ações e mais da metade do capital investido na indústria foi levantado por esse meio. O crescimento expressivo da Bolsa de São Paulo caiu fortemente a partir de 1913. Várias empresas faliram e o volume de ações negociadas diminuiu. Mas essa crise afetou de forma mais expressiva as pequenas empresas; as grandes continuaram intactas com suas ações na bolsa.

\footnotetext{
${ }^{26}$ A primeira bolsa de valores foi criada em 1843 no Rio de Janeiro.

${ }^{27}$ O surto especulativo nas bolsas de valores decorrente da política econômica republicana levou ao fechamento de várias empresas. Essa crise, conhecida como Encilhamento, trouxe recessão. Dezessete estabelecimentos bancários foram liquidados e o Brasil foi assolado por taxas de inflação que causaram a depreciação da taxa de câmbio e o encarecimento dos produtos importados.

${ }^{28}$ Bancos, ferrovias, serviços de utilidade pública e de transportes urbanos.
} 


\subsubsection{O crédito hipotecário e a crise de 1929}

Ao longo dos anos 1910 e 1920, vários aprimoramentos foram introduzidos no sistema financeiro nacional. Em 1919, o Banco do Brasil criou seu sistema de compensação de cheques e, em 1921, a Carteira de Redesconto. Segundo Sochaczewski (1993), ao longo da década de 1920, os bancos assumiam cada vez mais o papel de intermediários em transações comerciais, abandonando por completo suas atividades de emissão. A regulamentação da atividade bancária foi instituída em 1922, um ano após o Decreto 14.728, de 16 de março de 1921, que estabeleceu as diretrizes gerais do novo sistema. Com base nesse regulamento, foram concedidas 825 cartas patentes para novos estabelecimentos de crédito entre 1922 e 1929. Em 1929, o sistema bancário era razoavelmente desenvolvido e forte o bastante para resistir à depressão econômica.

Ainda assim, a crise de 1929 teve efeitos drásticos sobre a economia brasileira, com queda das receitas de exportações e recessão. A natureza especulativa da crise afetou as bolsas de valores, cujo crescimento já havia se retraído em relação aos primeiros anos do século XX. Houve retração de liquidez, com efeito sobre o crédito e o investimento. Estimativas de Morandi (2003) dão conta de uma redução forte da taxa de investimento na economia brasileira nesse período. A formação bruta de capital fixo, que fora de $11,0 \%$ do PIB brasileiro em 1929, caiu para 8,8\% em 1930 e continuou regredindo até 1933, quando atingiu o menor valor, $6,6 \%$.

Contudo, esse período marca importantes mudanças no perfil do crédito hipotecário brasileiro, as quais tiveram influência positiva na recuperação da economia após 1934. O Anuário Estatístico do Brasil traz alguns dados sobre as inscrições hipotecárias no século $\mathrm{XX}^{29}$, as quais são úteis para mostrar as mudanças no crédito ocorridas após a crise de 1929. Esses dados são apresentados nas tabelas do Anexo 4.1.

As quedas expressivas do número e do valor total dos contratos hipotecários foram acompanhadas de uma concentração nas áreas urbanas, cuja participação se ampliou após a crise. Esse fato sugere que a retração do crédito hipotecário afetou de forma mais intensa a agricultura do que a indústria e o comércio. Os valores de crédito continuaram concentrados em contratos grandes (com valores superiores a 100.000 mil réis).

\footnotetext{
29 O Anuário Estatístico do Brasil traz informações sobre o valor e o número de inscrições hipotecárias para o Brasil no período de 1909 a 1934. Optou-se por utilizar as informações de 1909, 1919, 1924, 1929, 1934. Os valores das hipotecas foram transformados em contos de réis de 1934 usando o índice de custo de vida do Rio de Janeiro (média 1912=100) do Ministério do Trabalho, Indústria e Comércio.
} 
Com relação à taxa de juros do financiamento, observou-se uma concentração em contratos com taxas de juros menores. Em 1909, 76,2\% dos contratos de crédito hipotecário tinham taxas de juros maiores que $10 \%$ ao ano. Esses contratos respondiam por quase a metade do valor total do crédito hipotecário. Em 1934, essas proporções caíram, tendo se elevado as participações do número e do valor dos contratos com taxas de juros de no máximo 10\% ao ano. Essa mudança se deve em parte à queda da inflação: entre 1923 e 1929, a taxa média de inflação era de 2,0\% ao ano e, na média do período 1929 e 1934, houve deflação de $1,2 \%$ ao ano.

A redução das taxas de juros, por outro lado, parece estar associada ao aumento dos empréstimos para financiamento do investimento de longo prazo em detrimento dos destinados ao custeio e ao capital de giro. De fato, observou-se uma tendência de maior concentração do crédito hipotecário em contratos com prazos mais longos, tanto em número quanto em valores. Em 1909, cerca de 90\% dos créditos hipotecários tinham prazo de até 5 anos. Em 1934, essa faixa diminui para cerca de 75\%. A maior mudança, contudo, foi com relação aos valores dos créditos hipotecários. Em 1934, 53,7\% do valor das inscrições hipotecárias referia-se a contratos com vencimento em mais de 5 anos; em 1909, essa participação era de apenas $33,6 \%$.

A conjugação de taxas de juros do crédito hipotecário menores, prazos de financiamentos maiores e valores médios mais elevados sugere que o efeito da crise foi menor para o crédito de longo prazo. Com isso, o financiamento ao investimento produtivo brasileiro não se retraiu tanto quanto o crédito em geral. Esse fato pode explicar a recuperação relativamente rápida do Brasil após a crise; a economia dos Estados Unidos, por exemplo, saiu da crise apenas no final da década de 1930.

O Gráfico 4.1.a apresenta a evolução do crédito hipotecário e do investimento em construção no Brasil entre 1923 e 1934. Nota-se uma relação positiva entre crédito hipotecário e investimento em construção até 1929. Com a crise, houve uma queda forte do investimento, cuja recuperação se deu a partir de 1932. Essa recuperação aparentemente não foi acompanhada pelo crédito hipotecário em geral. Contudo, como ilustra o Gráfico 4.1.b, o crédito hipotecário de longo prazo não se reduziu tanto quanto o crédito hipotecário em geral. Essa tendência também pode ser observada para o caso do investimento em máquinas e equipamentos (Gráficos 4.2.a e 4.2.b), que segue de perto a evolução do crédito de longo prazo. 
Gráfico 4.1. Crédito hipotecário e investimento em construção, Brasil, 1923-1934

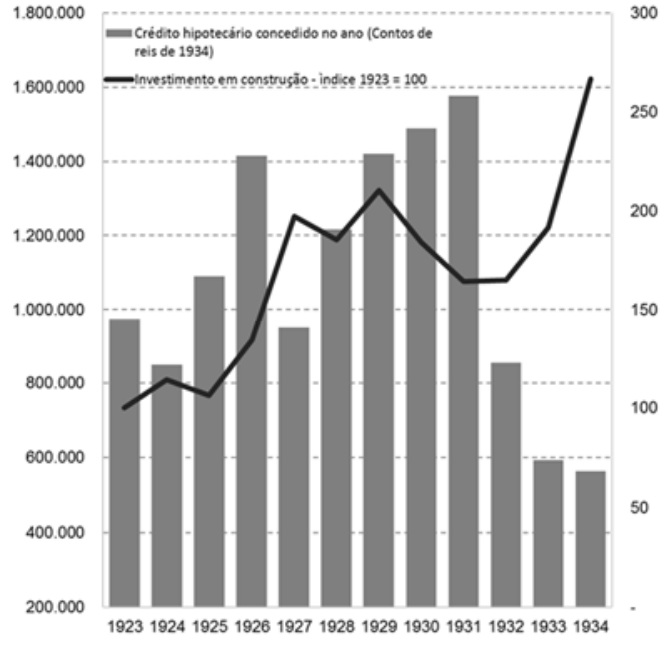

(a)

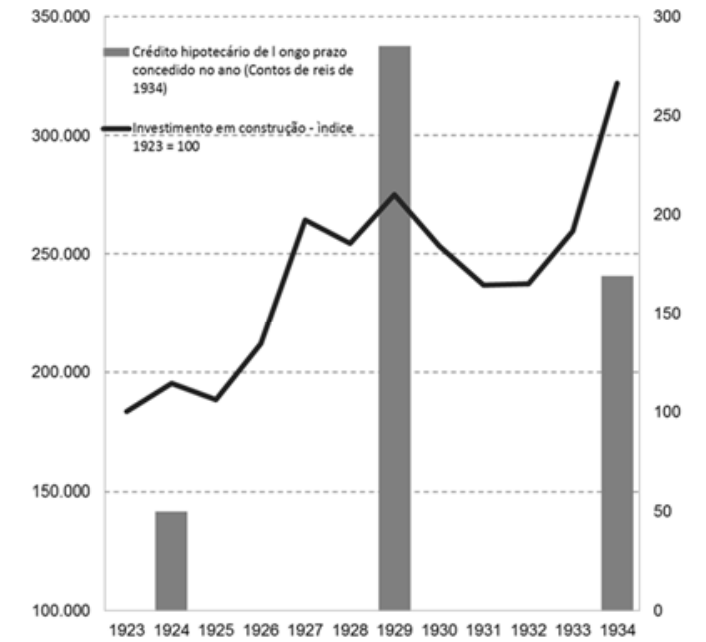

(b)

Gráfico 4.2. Crédito hipotecário e investimento em construção, Brasil, 1923-1934

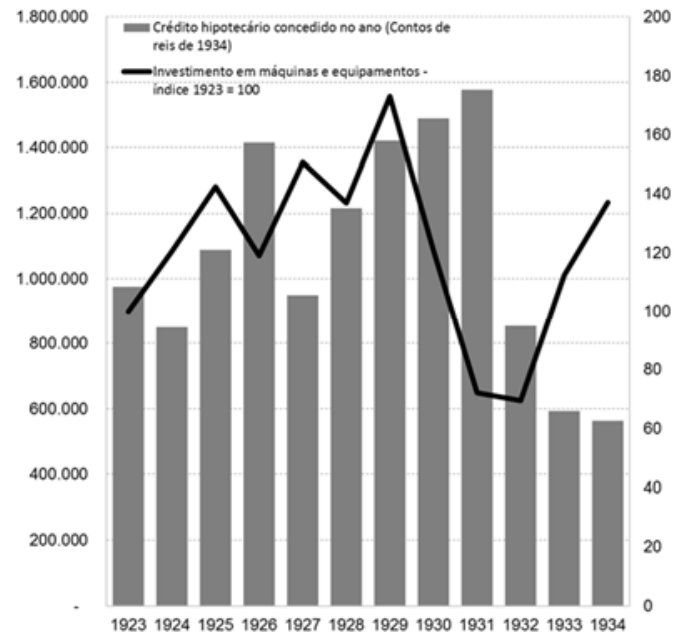

(a)

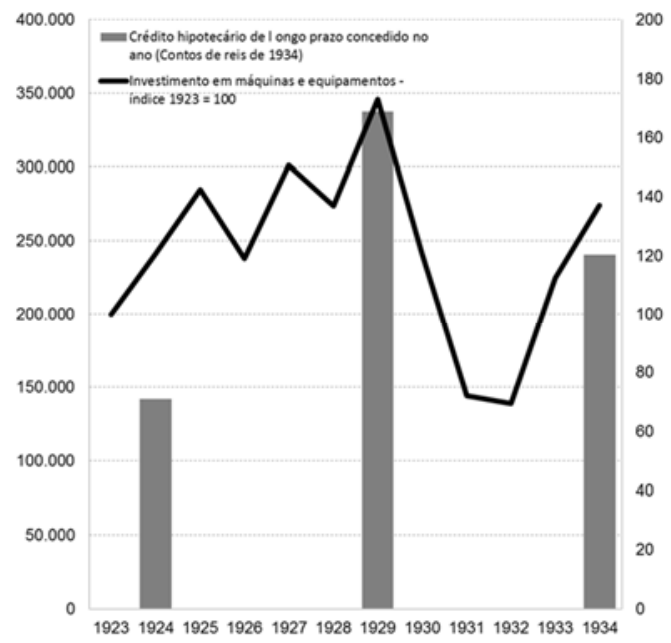

(b)

Fonte: Anuário estatístico do Brasil (vários anos) e Morandi (2003).

Conforme os efeitos da crise de 1929 se dissipavam, o crédito retornou à economia, desta vez com maior participação estatal. Conforme ilustra o Gráfico 4.3, os valores dos empréstimos alcançaram $£ 206,5$ bilhões em 1945, valor mais de cinco vezes o de 1939 ( $£$ 38,1 bilhões). É importante notar que, durante esse período, a fração dos empréstimos com relação ao total do ativo dos bancos variou entre $26 \%$ e $29 \%$, o que indica que também houve uma forte expansão dos depósitos bancários a prazo, ou seja, um aumento da poupança financeira.

Parte importante da expansão do crédito se deveu à ampliação promovida pelo Banco do Brasil. Em 1937, sob a lei n 454, foi criada a Carteira de Crédito Agrícola e Industrial do Banco do Brasil (CREAI), que também previu a instituição de títulos rurais. A assistência dada pela CREAI seria voltada para a aquisição de meios de produção, sementes, 
adubos e matérias primas para fins industriais; aquisição de gado destinado à criação e melhora de rebanhos; custeio de entressafra; e aquisição de máquinas agrícolas. Sua principal fonte de recursos era a emissão de bônus, que deveria ser realizada na proporção do montante dos empréstimos contratados.

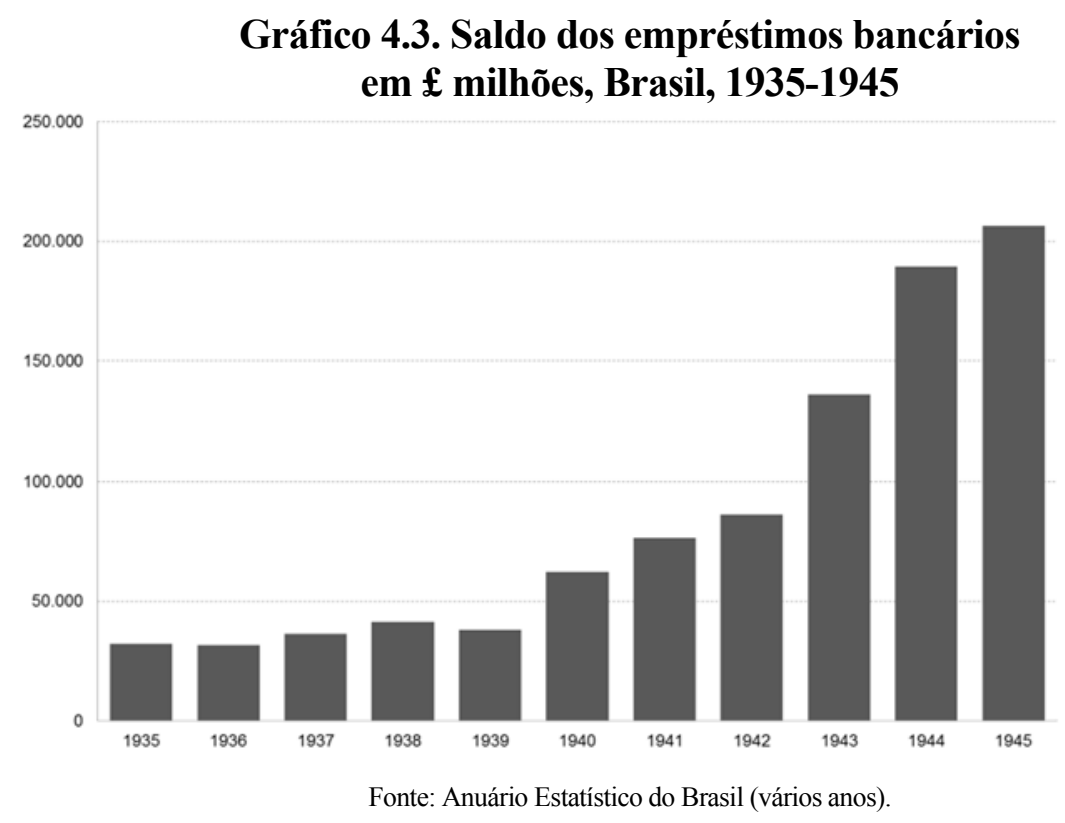

A partir de 1939, a CREAI passou a contar com novas fontes de recursos, como o recolhimento obrigatório de 20\% dos depósitos nas Caixas Econômicas Federais e Estaduais, $20 \%$ dos fundos de reservas das companhias de capitalização e $20 \%$ das reservas das companhias de seguro de qualquer natureza. Outra forma de assistência financeira ao investimento produtivo foi a emissão de letras hipotecárias negociáveis em bolsa. A propriedade dessas letras assegurava aos titulares direitos sobre ativos imobiliários dos devedores, sem que isso implicasse a perda da posse do ativo por parte do devedor. Com isso, segundo Silva (2007), o Banco do Brasil pôde prestar assistência à liquidação de dívidas constituídas sob garantias hipotecárias no período anterior à entrada em operação da CREAI. Segundo Araujo (2007), a criação da CREAI foi uma resposta do governo brasileiro à crescente demanda por crédito de uma economia em expansão, dentro do processo de industrialização por substituição de importações. No início, a CREAI tinha uma participação pequena no total de crédito concedido pelo Banco do Brasil. A partir de 1941 essa participação começa a aumentar, passando de 13,7\% para 40,9\% do total em 1945 - ver Tabela A.4.2.1 do Anexo 4.2. 


\subsection{A fundação do financiamento de longo prazo}

\subsubsection{Necessidade de mudanças e o BNDE}

O mercado financeiro brasileiro no imediato pós-guerra era formado pelos bancos comerciais privados e pelo Banco do Brasil. O Banco do Brasil era responsável pela política monetária e atuava como banco comercial. Como executor da política monetária, administrava as carteiras de redescontos (CARED) e a Caixa de Mobilização Bancária (CAMOB), com as quais controlava as emissões e atuava como o banco dos bancos. A Superintendência da Moeda e do Crédito (SUMOC), criada em 1945, tornou-se responsável pela coordenação das carteiras do Banco do Brasil e, por meio de suas instruções, também controlava o crédito. ${ }^{30}$

O crédito dos bancos comerciais era de curto prazo, essencialmente para prover o capital de giro das empresas. O financiamento de longo prazo era feito pelo Banco do Brasil, por meio das carteiras de Crédito Geral (CREGE) e Crédito Agrícola e Industrial (CREAI).

Segundo Araujo (2007), no imediato pós-guerra, o governo brasileiro insistia na necessidade de o governo norte-americano demonstrar sua gratidão apoio brasileiro aos países aliados com auxílio financeiro aos moldes do Plano Marshall. É neste contexto que deve ser interpretada a criação, em 1948, da Comissão Mista Brasileiro-Americana de Estudos Econômicos. ${ }^{31}$ A Comissão diagnosticou que a inflação crônica era causada pelo déficit fiscal, coberto por emissão monetária e expansão do crédito. Para resolver esse problema, o Brasil deveria aplicar uma política ortodoxa de contenção monetária, creditícia e fiscal. Além disso, foi sugerida uma reforma no sistema monetário e financeiro que criasse (i) mecanismos para o maior controle do crédito de curto prazo e (ii) um banco central independente. O financiamento ao desenvolvimento deveria ser feito por métodos não inflacionários - aumento da arrecadação ou mercado de títulos.

Com o retorno de Getulio Vargas ao poder, em 1951, houve a retomada da aspiração à industrialização acelerada como condição para o progresso social e econômico. A política econômica de seu governo favoreceu a expansão do crédito. Em 1951, foi criado o

\footnotetext{
${ }^{30}$ Segundo Araujo (2007), dentro desse contexto institucional, os empréstimos do Banco do Brasil tinham um importante papel na condução da política monetária. O Banco do Brasil tinha papel ativo e passivo no processo de expansão monetária. Como agente financeiro do governo, exercia um papel passivo ao conceder crédito ao Tesouro Nacional e a outras entidades públicas. Como banco comercial, exercia um papel ativo, competindo com os demais bancos comerciais.

${ }^{31}$ Essa missão ficou conhecida como Missão Abbink, pois, o chefe do grupo técnico norte-americano era John Abbink. O grupo brasileiro foi chefiado por Octávio de Bulhões.
} 
Banco Nacional de Crédito Cooperativo, que dava assistência e amparo às cooperativas (especialmente de produtores agrícolas) $^{32}$. No mesmo ano, foi criada a Comissão Mista Brasil-Estados Unidos para o Desenvolvimento Econômico, esforço de planejamento muito mais ambicioso do que o empreendido no governo Dutra pela Missão Abbink. Essa comissão sugeriu a criação de instrumentos de financiamento não inflacionário, que acabou influenciando a decisão de fundar, em 1952, o Banco Nacional de Desenvolvimento Econômico (BNDE) com o objetivo de financiar projetos de desenvolvimento de longo prazo no país.

O BNDE foi criado pela Lei 1.664, de 20 de junho de $1952 .{ }^{33} \mathrm{O}$ novo banco teria a forma de uma autarquia, a qual foi justificada pela necessidade de se submeter à físcalização do Tribunal de Contas, já que seus recursos seriam oriundos do adicional sobre o imposto de renda. O BNDE não estaria autorizado a receber depósitos comerciais, pois a captação dos recursos a curto prazo não seria compatível com o caráter dos empréstimos que ofereceria. $^{34}$

A captação de recursos do BNDE era constituída de recursos nacionais e estrangeiros. Os recursos domésticos eram obtidos por repasses oriundos do adicional do imposto de renda. Os recursos estrangeiros eram oriundos de duas entidades internacionais: o Banco Mundial e o Eximbank. O aporte inicial de recursos seria da ordem de US\$ 500 milhões. Contudo, dois acontecimentos modificaram a relação do Brasil com os Estados Unidos e esses recursos não chegaram a US\$ 200 milhões. O primeiro acontecimento foi à mudança na política externa dos Estados Unidos com os países latino-americanos a partir da eleição de Eisenhower no final de 1952. Sua política previa o corte de recursos para esses países, já que não havia uma ameaça comunista iminente. $\mathrm{O}$ segundo acontecimento deu-se no início de 1953, quando Vargas implementou a política de taxas múltiplas de câmbio para desesti-

\footnotetext{
32 O BNCC foi extinto em 1990 pelo Decreto $\mathrm{n}^{\circ} 99.192$.

${ }^{33}$ Lafer (1948), citado por Araujo (2007) - LAFER, H. O Crédito e o sistema Bancário no Brasil. Imprensa Nacional, Rio de Janeiro, 1948 -, considerava que a criação de uma instituição como o BNDE possibilitaria especializar e capacitar de forma adequada uma instituição de crédito de longo prazo, retirando do Banco do Brasil as funções para as quais ele não tinha vocação. Já para Furtado (1982), citado por Araujo (2007) - FURTADO, C. Projeto Memória, $1^{\text {a }}$ fase, transcrição do VT 13, Rio de Janeiro: BNDES em 22/06/1982 - o que faltava ao Brasil era uma grande instituição de financiamento que mobilizasse a massa de recursos necessários para a transformação que a economia iria exigir no futuro. Não bastava criar mecanismos de financiamentos não inflacionários, era preciso criar uma nova instituição.

${ }^{34}$ Segundo Araujo (2007), as instituições existentes não tinham quadros técnicos nem métodos adequados ao planejamento de longo prazo, pois as operações de um banco comercial são intrinsicamente diferentes da lógica de um banco de desenvolvimento. Essa opinião foi reforçada por Tavares et al (2010), para quem o quadro de funcionários do Banco do Brasil não era adequado às necessidades de um banco de investimento. Os funcionários do Banco do Brasil (inclusive os alocados na CREAI) estavam preocupados com garantias e com taxas de juros, pois se tratava de uma operação comercial. Eles não estavam interessados com o efeito do crédito sobre o longo prazo da economia, preocupação típica de um banco de desenvolvimento.
} 
mular a importação e a remessa de lucros. Nesse período, Vargas também criou a Petrobrás, outra ação nacionalista que não agradou aos norte-americanos, segundo Araujo (2007).

Nos primeiros anos de sua existência, o BNDE enfrentou dificuldades na captação de recursos. Havia lentidão para o repasse do adicional do imposto de renda. Assim, a inflação reduzia o poder de compra desses recursos. Entre 1952 e 1955, somente 38,9\% dos recursos oriundos do adicional do imposto de renda foram efetivamente repassados para $\mathrm{o}$ BNDE. No início, o adicional do imposto de renda foi uma fonte mais expressiva. Em 1952, ela representou $19,7 \%$ do total de recursos disponíveis do BNDE. Mas, ao longo dos anos, essa fonte diminuiu sua importância. Em 1959, ela era responsável apenas por 3,2\% dos recursos disponíveis do BNDE - ver Anexo 4.3.

Conforme aponta Araujo (2007), a escassez de recursos levou o BNDE a ser mais seletivo na escolha dos projetos. Com isso, priorizaram-se os setores de transporte e energia. Uma alternativa encontrada para suprir a escassez de fundos nacionais foi à criação dos chamados recursos vinculados, que eram oriundos da arrecadação de taxas criadas por força de lei e que tinham sua vinculação na origem e no destino, com o intuito de estimular setores específicos da economia. ${ }^{35}$ Esses recursos aumentaram paulatinamente sua participação, passando de 5,2\% do total de recursos disponíveis, em 1955, para 8,2\%, em 1959.

Com relação aos recursos externos, uma parte pequena da escassez foi resolvida em 1955 com a assinatura dos chamados Acordos de Trigo. Conforme esses acordos, os Estados Unidos financiariam a compra pelo Brasil dos excedentes agrícolas norte-americanos e os recursos equivalentes seriam convertidos em cruzeiros à taxa a ser acordada entre os dois países. Até 1964, foram feitos quatro acordos. Esses acordos foram pouco expressivos no total de recursos do BNDE: em 1956, ele representou 2,0\% do total de recursos do BNDE, caindo para $1,5 \%$ do total em 1959.

De acordo com a Lei 1.474, o ano de 1956 seria o último com arrecadação do adicional do imposto de renda. Para piorar a situação, o número de pedidos de financiamento foi maior que o esperado. Até esse ano, os pedidos de financiamento ao BNDE somaram Cr\$ 47,1 milhões, tendo sido aprovados apenas Cr\$ 15,2 milhões, ou 32\% do total (Araujo, 2007).

\footnotetext{
${ }^{35}$ Os recursos vinculados são um tipo de arrecadação tributária incidente sobre o consumo ou produção de um determinado bem com a finalidade de promover o investimento em projetos em setores especificados na legislação. Exemplos: (i) Fundo Federal de Eletrificação, criado pela Lei 2.308, de 31 de agosto de 1954; (ii) Fundo de Renovação e Melhoramento das Ferrovias e Fundo de Renovação Patrimonial, criados pelo Decreto 37.686 de 02 de agosto de 1955; (iii) Fundo de Pavimentação e Fundo para Substituição de Ramais Ferroviários, criados pela Lei 2.698, de 22 de dezembro de 1955; e (iv) Imposto Único sobre Combustíveis e Lubrificantes, criado pela Lei 2.975 de 1956.
} 


\subsubsection{O financiamento de longo prazo e o Plano de Metas}

Em 1956, Juscelino Kubitschek assumiu a presidência e, no mesmo ano, lançou o Plano de $\mathrm{Metas}^{36}$. O plano obteve relativo sucesso e, para tanto, o BNDE teve um papel decisivo. Segundo Tavares et al. (2010), uma das razões do êxito estava na capacidade de coordenação centralizada e na supervisão direta feita pelo presidente. Os investimentos do Estado, principalmente em infraestrutura e energia, foram financiados pelo BNDE.

Embora, o BNDE fosse um órgão fundamental para o financiamento do Plano de Metas, ele continuava enfrentando grandes problemas de escassez de recursos. Assim, para que ele pudesse ser utilizado no financiamento do plano, sua forma de captação de recursos foi revisada. O presidente encaminhou ao Congresso o Projeto de Lei $n^{\circ} 442$, que tinha como objetivo prorrogar por mais 20 anos a arrecadação do adicional do imposto de renda como fonte de recursos do BNDE. A Lei 2.973, de 26 de novembro de 1956, definiu a prorrogação por mais 10 anos e determinou que o adicional passasse a ser diretamente transferido para a conta do BNDE de modo a agilizar o repasse. Outra novidade foi a obrigatoriedade de aplicação de $25 \%$ dos recursos em regiões menos desenvolvidas.

O Plano de Metas foi importante para o desenvolvimento do BNDE porque, a partir dele, novas fontes não inflacionarias de recursos foram criadas. O governo Kubitschek criou, por exemplo, o Fundo Portuário Nacional (Lei 3.421 de 10 de julho de 1958) e o Fundo da Marinha Mercante (Lei 3.381 de 24 de abril de 1958), que representaram 3,1\% do total de recursos do BNDE na média do período 1958-1959. Essas novas fontes, mais estáveis que o adicional do imposto de renda, foram se tornando gradativamente mais importantes.

A Tabela 4.1 traz os valores dos desembolsos do BNDE com Operações Contratadas e sua participação na formação bruta de capital fixo total e nos investimentos em máquinas e equipamentos entre 1953 e 1965. Houve crescimento expressivo dos desembolsos do BNDE e aumento de sua participação no investimento durante o Plano de Metas. Ainda assim, os desembolsos do BNDE representaram apenas 1,9\% dos investimentos brasileiros em 1959. Esses recursos foram investidos em sua maioria no setor de energia, conforme ilustram a Tabela A.4.3.2 do Anexo 4.3.

\footnotetext{
${ }^{36}$ Esse plano foi um programa federal de investimento público que abrangeu os setores de energia, transportes, alimentação, indústria de base e educação, e estabeleceu 30 metas que deveriam ser implementadas em cinco anos. Para Lafer (1973), o Plano de Metas pode ser considerado "como a primeira experiência efetivamente posta em prática de planejamento do governo federal” (Lafer, 1973, p. 30).
} 
Tabela 4.1 Desembolsos do BNDE com operações contratadas e formação bruta de capital fixo, em milhões de Cr\$, 1953 a 1965

\begin{tabular}{|c|c|c|c|c|c|}
\hline & 1953 & 1956 & 1959 & 1962 & 1965 \\
\hline Desembolsos do BNDE (A) & 0,41 & 2,46 & 7,92 & 10,11 & 85,00 \\
\hline Formação bruta de capital fixo (B) & 73,70 & 148,80 & 417,20 & $1.156,20$ & $6.276,80$ \\
\hline (\%) desembolsos no investimento (A/B) & $0,56 \%$ & $1,65 \%$ & $1,90 \%$ & $0,87 \%$ & $1,35 \%$ \\
\hline FBKF em máquinas e equipamentos (C) & 22,10 & 50,90 & 165,20 & 415,30 & $2.074,40$ \\
\hline (\%) desembolsos no investimento (A/C) & $1,88 \%$ & $4,83 \%$ & $4,80 \%$ & $2,43 \%$ & $4,10 \%$ \\
\hline
\end{tabular}

Fonte: VIII Exposição sobre o Programa de Reaparelhamento Econômico, 1959, BNDE. Memorias do Desenvolvimento, vol. 2, 2008 e Estatísticas Históricas do Brasil, IBGE.

A criação do BNDE não significou a extinção do financiamento ao investimento produtivo por meios inflacionários. A CREAI continuou a operar e a prover financiamento ao setor produtivo, dada sua facilidade de captação de recursos (Carteira de Redescontos). No entanto, houve uma redefinição do papel da CREAI com relação ao financiamento ao setor industrial: o perfil do crédito concedido passou a ser de curto prazo e concentrou-se nos setores mais tradicionais da indústria. Os empréstimos concedidos continuaram crescendo: os saldos médios dos empréstimos da CREAI passaram de Cr\$ 7,9 milhões, em 1951, para Cr\$24,1 milhões, em 1956 (24,8\% ao ano). ${ }^{37}$

\section{Gráfico 4.4 Participações da concessão líquida de empréstimos da CREAI e dos desembolsos do BNDE na formação bruta de capital fixo, 1953-1960}

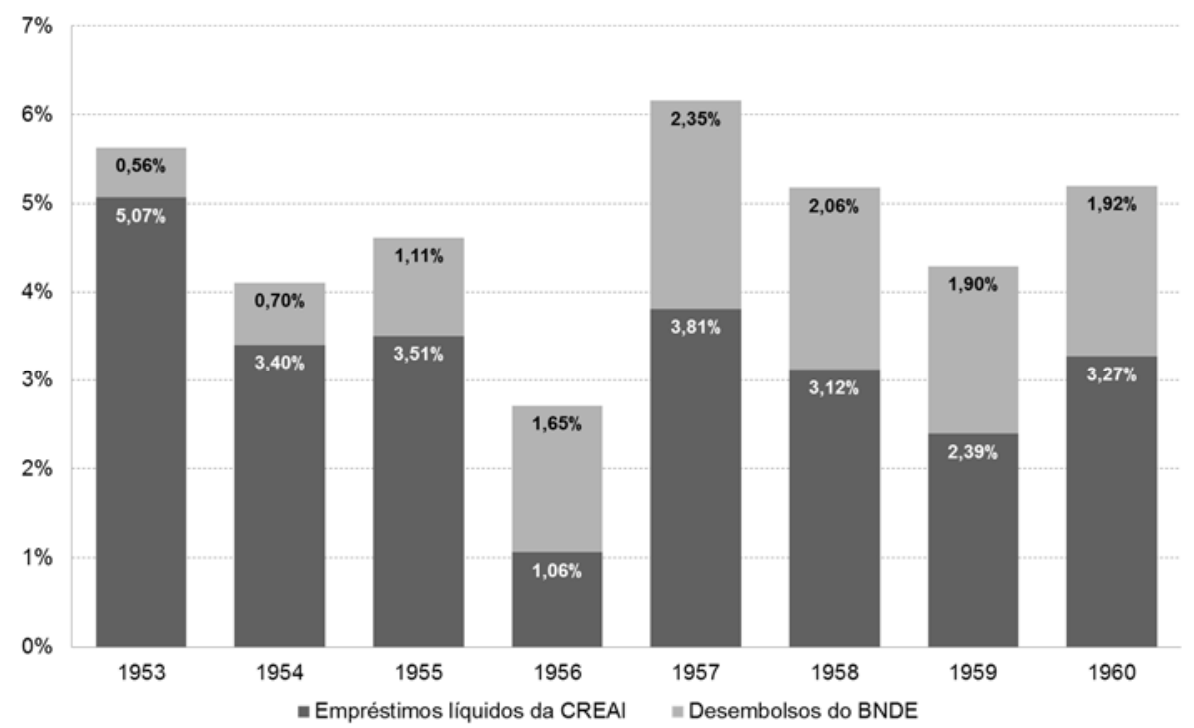

Fonte: Beskow (1994), Estatísticas Históricas do Brasil, IBGE e VIII Exposição sobre o Programa de Reaparelhamento Econômico, 1959, BNDE. Memorias do Desenvolvimento, vol. 2, 2008.

O Gráfico 4.4 traz a participação da concessão líquida dos empréstimos da CREAI e dos desembolsos do BNDE na formação bruta de capital fixo do país. Observa-se, em primeiro lugar, que essas relações eram muito baixas, o que indica que o financiamento do

\footnotetext{
37 Também nessa época surgiram as financeiras, que eram sociedades de crédito, financiamento e investimento criadas para apoiar a demanda por bens duráveis de consumo no país (eletrodomésticos e automóveis), cuja instalação da indústria constituía objetivo do Plano de Metas.
} 
investimento contava com poucos recursos dessas duas fontes, requerendo um esforço maior de autofinanciamento e outras modalidades de crédito e captação de recursos. Em 1953, a relação entre concessão líquida dos empréstimos da CREAI com o investimento foi a maior do período - de 5,1\%. Em 1957, os dois fundos alcançaram a maior relação com o investimento, - de $6,2 \%$.

A década de 1950 observou elevadas taxas de crescimento, com uma média de $8,1 \%$ ao ano. A economia brasileira passou por uma mudança estrutural, com rápida elevação da taxa de participação da indústria no PIB - de 26\%, em 1955, para 33\%, em 1960. Nesse período, o investimento também cresceu de forma expressiva: 8,4\% ao ano. Os principais investimentos industriais ocorreram na fabricação de automóveis, de material elétrico e na indústria metalomecânica, setores que representaram um salto tecnológico.

\subsection{A reforma financeira dos anos 1960 e seu impacto sobre o desenvolvimento}

\subsubsection{A reformulação do Sistema Financeiro Nacional}

A elevação da inflação ao final dos anos 1950 e início dos anos 1960 tornou os juros reais negativos, pois as taxas nominais de juros estavam limitadas a 12\% ao ano. Houve redução nas captações de depósitos a prazo e restrição de crédito, num processo de gradual desarticulação da intermediação financeira. O investimento privado caiu 26,8\% entre 1959 e 1961 e manteve-se em patamar relativamente reduzido até 1965, mesmo com a busca de elevação do investimento público durante o governo João Goulart.

$\mathrm{O}$ declínio econômico e a crise política levaram à ruptura de regime. O governo militar instituído após o golpe de 1964 deu início a uma série de reformas institucionais que criaram novos instrumentos de política econômica e reformularam profundamente as instituições do sistema financeiro e da estrutura administrativa do setor público brasileiro. Para controlar a inflação, que foi de 52\% entre 1960 e 1963, e reequilibrar o balanço de pagamentos, o novo governo adotou o Programa de Ação Econômica do Governo (PAEG).

A estrutura do mercado de crédito foi profundamente reformulada e as linhas básicas de sua organização prevalecem ainda hoje. Com a Lei $n^{\circ} 4.595$, de $1^{\circ}$ de dezembro de 1964, a reforma bancária redefiniu o papel do Banco do Brasil e criou o Conselho Monetário Nacional (CMN) e o Banco Central do Brasil (BACEN). O Banco Central incorporou a Carteira de Redescontos e a Caixa de Mobilização Bancária do Banco do Brasil e assumiu algumas funções de controle anteriormente de responsabilidade da Carteira de Câmbio do Banco do Brasil. Ao Banco Central também foi dada ampla competência sobre a atividade 
econômica nacional, com destaque para a emissão de papel-moeda, execução dos serviços do meio circulante, recebimento de depósitos compulsórios, operações de redesconto, depósitos das reservas internacionais do país, financiamento das necessidades de caixa do Tesouro Nacional e controle de capitais estrangeiros e de crédito. A mesma Lei transformou o Banco do Brasil num "instrumento de execução da política creditícia e financeira do governo federal", concedendo-lhe um conjunto de novas funções. As atividades desenvolvidas por meio da Carteira de Crédito Geral e da Carteira de Crédito Agrícola e Industrial não sofreram alteração. ${ }^{38}$

A Lei $n^{\circ} 4.728$, de 14 de julho de 1965, redefiniu as funções dos bancos comerciais e demais instituições financeiras, tendo como ponto de partida o desenho segmentado e funcional do sistema norte-americano. Os bancos comerciais ficaram com as operações de curto prazo. As recém-criadas sociedades de crédito e financeiras foram encarregadas das operações de médio prazo. Os bancos de investimento ficaram com o financiamento de longo prazo. Já a Lei n 4.357, de 16 de julho de 1964, reformou o sistema tributário e criou a correção monetária. Martone et al. (1986) destaca que essa medida foi a mais importante para a retomada da intermediação financeira no país, pois permitiu que os contratos de empréstimos tivessem taxas de juros reais positivas.

Na nova estrutura, a qual é ilustrada na Figura 4.1, o Conselho Monetário Nacional ocupou o topo do sistema financeiro brasileiro, com funções normativas sobre todas as demais instituições financeiras. A ele foi atribuída à função de estabelecer metas e diretrizes para as políticas monetária, creditícia e financeira do país. O Banco Central e o Banco do Brasil tinham a autoridade monetária, com poder executivo sobre a política. O Conselho Monetário tinha dois outros agentes executivos: o BNDE e o Banco Nacional da Habitação $(\mathrm{BNH})^{39}$. As instituições financeiras ficaram na base da estrutura do sistema, com atuação especializada em segmentos do mercado financeiro. A segmentação foi pensada para dar cobertura a todas as necessidades de crédito da economia (produção, consumo, exportação e investimento) e para permitir uma maior especialização dos agentes financeiros.

\footnotetext{
38 "Entre as funções atribuídas ao Banco do Brasil com a Lei n 4.595 estão: (i) receber, a crédito do Tesouro, as importâncias provenientes da arrecadação de tributos ou rendas federais e o produto das operações ligadas à colocação de obrigações, apólices ou letras do Tesouro Nacional; (ii) realizar os pagamentos e suprimentos necessários à execução do Orçamento Geral da União e leis complementares, de conformidade com as autorizações do Ministério da Fazenda, as quais não poderia exceder o nível global dos recursos a ele recolhidos, sendo vedada ao estabelecimento a concessão de créditos de qualquer natureza ao Tesouro; (iii) conceder aval, fiança e outras garantias, consoante expressa autorização legal; (iv) adquirir e financiar estoques de produção exportável; (v) executar a política de preços mínimos dos produtos agropecuários, ser agente pagador e recebedor fora do país; e (vi) executar o serviço da dívida pública consolidada.” (Banco do Brasil, p. 191, 2010).

${ }^{39}$ Em 1986, o BNH foi extinto e suas atribuições executivas de crédito foram transferidas para a Caixa Econômica Federal (CEF).
} 
Figura 4.1 Estrutura do Sistema Financeiro Nacional criado em 1964

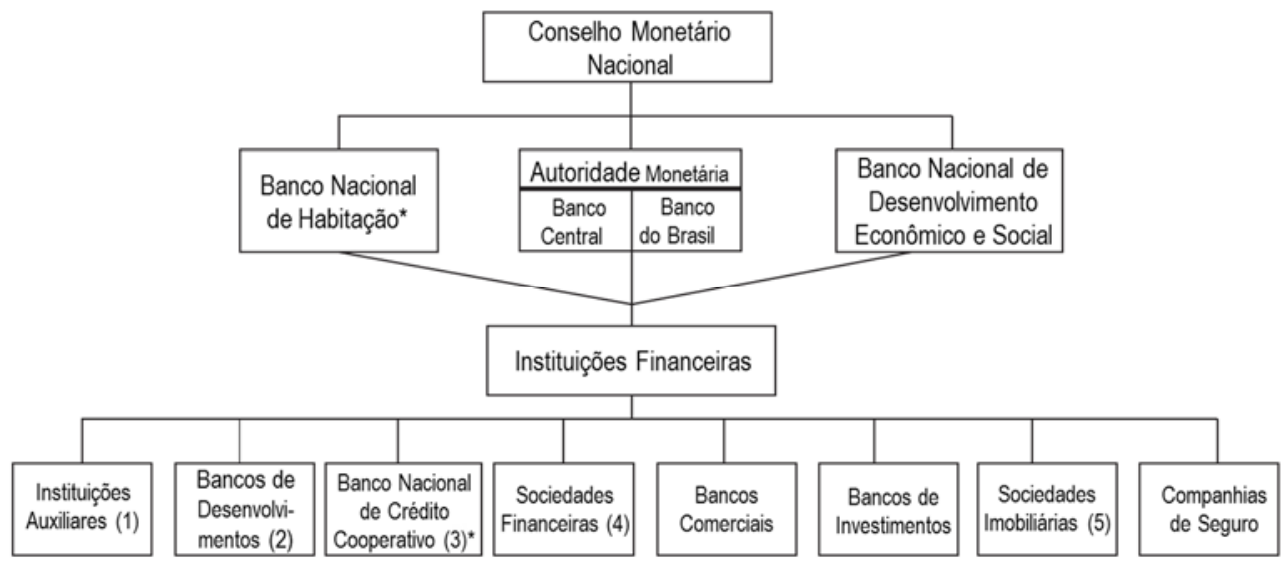

Fonte: Martone (1986). Notas: (1) Fazem parte os agentes autônomos, as bolsas de valores, as corretoras e distribuidoras de títulos e valores; (2) Fazem parte os bancos estaduais de desenvolvimento, o Banco da Amazônia e o Banco do Nordeste do Brasil; (3) Estão inclusas no BNCC as cooperativas de crédito; (4) Fazem parte as sociedades de investimento, o arrendamento mercantil, os fundos de investimentos e as financeiras; (5) Fazem parte as cooperativas habitacionais, as associações de poupança e empréstimos, as sociedades de crédito imobiliário e as caixas econômicas. (*) essas instituições foram extintas e 1986 e 1990.

O BNH foi criado pela Lei $n^{\circ} 4.380$, de 21 de agosto de 1964, que instituiu também o Plano Nacional da Habitação e criou o Sistema Financeiro da Habitação (SFH) e o Serviço Federal de Habitação e Urbanismo. O SFH reuniu os agentes responsáveis pela captação de fundos, pelas operações de financiamento para a aquisição da casa própria e pela construção e venda de moradias. Ao BNH foi atribuída a competência de orientar e controlar o SFH e de promover a construção e a aquisição da casa própria para famílias de baixa renda. O Serviço Federal de Habitação e Urbanismo ficou responsável pela promoção de estudos e pesquisas para o desenvolvimento da habitação e da cadeia da construção. A captação de recursos do BNH se deu por dois instrumentos básicos: (i) a poupança voluntária, constituída pelas cadernetas de poupança e pelas letras imobiliárias; e (ii) a poupança compulsória proveniente do Fundo de Garantia por Tempo de Serviço (FGTS ${ }^{40}$.

O BNDE manteve-se voltado para o financiamento do investimento de longo prazo e tinha como agentes os bancos de desenvolvimento regionais. A captação de recursos do BNDE foi ampliada, mas a carência de fundos só foi devidamente resolvida com a criação, em 1971, do Programa de Integração Social (PIS) e do Programa de Formação do Patrimônio do Servidor (PASEP), os quais foram mantidos por meio de contribuições das empresas e do governo. A contribuição das empresas passou a incidir sobre o faturamento e a do governo, sobre o imposto de renda.

\footnotetext{
40 O Fundo de Garantia por Tempo de Serviço (FGTS), criado em 1967 para substituir o estatuto da estabilidade no emprego, passou a arrecadar mensalmente contribuições de $8 \%$ sobre os salários dos trabalhadores com carteira assinada e seus recursos foram destinados aos empréstimos cedidos pelo BNH. Os depósitos das famílias no FGTS também serviam de poupança prévia para a compra da casa própria do trabalhador.
} 
Também foram criados novos fundos que geravam mais recursos para o BNDE, possibilitando a expansão de suas atividades. Dentre os novos fundos (ver Quadro A.4.4.1 do Anexo 4.4), o FINAME foi o mais importante e flexível, tanto na dimensão quantitativa como na qualitativa. Seu objetivo era prover recursos para a aquisição de máquinas e equipamentos industriais de produção nacional. Em pouco tempo, o fundo se tornaria uma das mais importantes fontes de recursos do BNDE. Entretanto, nem todos os fundos criados representaram novos recursos para o BNDE. O FUNTEC e o FUNDEPRO foram instituídos com meios do próprio BNDE, por iniciativa de setores que já estavam desenvolvendo projetos, ou seja, eles constituíam uma mera reserva com destinação específica.

Outra importante modificação introduzida nesse período foi a Lei $\mathrm{n}^{\circ} 4.506$, de 30 de novembro de 1964, que extinguiu o Adicional ao Imposto de Renda a partir de 1965. Esses recursos foram substituídos pela destinação de $20 \%$ da arrecadação do Imposto de Renda ao BNDE. ${ }^{41}$ Essas modificações levaram à consolidação do novo perfil do BNDE, que se voltou prioritariamente para o fomento e financiamento do setor industrial. De acordo com a Tabela A.4.4.1 a participação da indústria no total das operações aprovadas do BNDE flutuou entre 69\% e 96\% do total dos empréstimos no período 1965-1968.

\subsubsection{Ascenção e queda do crédito e do investimento}

No período entre 1965 e 1968, o PIB brasileiro cresceu a uma taxa média anual de $6,9 \%$, o investimento aumentou $15,1 \%$ ao ano e o crédito total ao setor privado, $14,7 \%$ ao ano. As reformas da década de 1960 reverteram a trajetória de estagnação econômica e recuperaram a capacidade de poupança do país. No período entre 1968 e 1973, o PIB cresceu $11,4 \%$ ao ano, o investimento aumentou $13,8 \%$ ao ano e o crédito total ao setor privado, $22,4 \%$ ao ano. ${ }^{42}$

Além das consequências da reforma financeira, a recuperação do investimento interno foi favorecida pela captação de recursos no exterior, a qual foi facilitada pela Lei $\mathrm{n}^{\mathrm{o}}$ 4.131, de 3 de setembro de 1962, que abriu o acesso das empresas ao sistema financeiro internacional. A Resolução no 63 do BACEN, de 21 de agosto de 1967, também contribuiu nesse sentido, ao possibilitar a captação de recursos externos por parte dos bancos comerciais.

\footnotetext{
${ }^{41}$ Vale destacar que a modificação associada à reforma tributária elevou substancialmente a arrecadação do Imposto de Renda e, portanto, aumentou substancialmente os recursos repassados ao BNDE.

${ }^{42}$ Dados do IBGE e Banco Central do Brasil. Para maiores detalhes ver descrição das variáveis no Capítulo 6.
} 
Esse período foi marcado por três planos de desenvolvimento que articularam o investimento. O Programa Estratégico de Desenvolvimento (PED) foi lançado em 1968 com o objetivo de estabelecer um piso para a taxa de crescimento do PIB de $6 \%$ ao ano. A política monetária seria conduzida de acordo com as necessidades do PED, expandindo o crédito ao setor privado e distribuindo-o com atenção aos setores que seriam a fonte de dinamismo para a economia ${ }^{43}$. O PED previa ainda que o déficit público fosse financiado com fontes que não a expansão de moeda e que o aumento da produção fosse feito por meio da expansão do investimento. O PED deu papel de destaque ao BNDE no apoio à expansão do investimento. Contou, também, com o apoio de outras instituições como o Banco do Brasil, Banco da Amazônia e Banco do Nordeste.

Em 1971, foi criado o Plano Nacional de Desenvolvimento (I PND), com os seguintes objetivos: (i) colocar o Brasil entre as nações desenvolvidas; (ii) duplicar a renda per capita, até 1980; e (iii) expandir a taxa de crescimento do emprego para 3,2\% até 1974. O plano enfatizava, ainda, a importância da maior participação do sistema financeiro nacional e do mercado de capitais para a formação de capital das empresas e para incentivar os esforços para a melhoria geral dos recursos humanos. O I PND previa que o BNDE também deveria operar na concessão de crédito de médio e de longo prazo às empresas por meio de mecanismos que facilitassem a mobilização de recursos, como as debêntures, simples ou conversíveis em ações, os certificados de depósitos e as letras de câmbio. Os recursos viriam do próprio BNDE, da Caixa Econômica Federal, do Banco do Brasil, do Banco Mundial e da AID (Agency for International Development dos Estados Unidos).

Apesar das novas fontes de recursos obtidas pelas reformas de década de 1960, o BNDE só encontrou maior estabilidade de financiamento depois que passou a receber recursos do PIS/PASEP. Os recursos desses programas foram inicialmente entregues ao Banco do Brasil, muito embora tivessem uma natureza de longo prazo. Apenas em 1974, com a implantação do II Plano Nacional de Desenvolvimento (II PND), os recursos do PIS/PASEP foram repassados ao BNDE.

Com as reformas implantadas no campo financeiro e os programas de desenvolvimento econômico, o crédito e o investimento cresceram juntos no país, propiciando uma expansão forte da economia. O crédito total da economia expandiu-se à taxa de $16,0 \%$ ao ano, o crédito do BNDE, à taxa de 19,4\%, e o investimento, à taxa média anual de $14,1 \%$

\footnotetext{
${ }^{43}$ Os setores considerados estratégicos pelo PED eram: bens de capital, bens intermediários e a indústria tradicional.
} 
entre 1967 e 1980. Nesse período, o Brasil experimentou taxas de crescimento do PIB de $8,9 \%$ ao ano, o que implicou um crescimento de $6,3 \%$ ao ano da renda per capita.

Após a euforia do período do 'milagre econômico', o governo Figueiredo, (19791984) foi marcado pelo agravamento da crise econômica internacional provocada pelo segundo choque do petróleo, em 1979, e pela elevação das taxas de juros internacionais. O cenário interno era bastante restritivo, marcado pela inflação crescente e pela crise do balanço de pagamentos. Houve crise fiscal, agravada pelo segundo choque do petróleo, e a recessão norte-americana não só diminuiu as exportações brasileiras, como provocou a queda nas fontes externas de financiamento. $\mathrm{O}$ governo brasileiro adotou um conjunto de medidas com ajuste fiscal e contração do crédito para o setor privado. $\mathrm{O}$ crédito ao setor privado caiu 12,3\% ao ano entre 1979 e 1982, com retração do investimento de 3,7\% ao ano. A taxa média de crescimento do PIB passou para 1,8\% ao ano nesse período, com variação negativa do PIB per capita.

A 'crise da dívida' decorrente da moratória mexicana, em 1982, afastou os credores internacionais das economias periféricas. Com o agravamento da crise, o Brasil foi obrigado a abandonar o caminho desenvolvimentista que trilhara ao longo de seu processo de industrialização. O longo ciclo de expansão do crédito e do investimento deu lugar a uma política macroeconômica de curto prazo voltada para as necessidades de ajuste conjuntural.

O BNDE sofreu grandes mudanças nesse período. A principal delas foi introduzida pelo Decreto-Lei ${ }^{\circ} 1.940$, de 25 de maio de 1982, que criou o Fundo de Investimento Social (FINSOCIAL). Esse fundo tinha como objetivo captar recursos para o desenvolvimento de programas nas áreas de produção agrícola, educação, saúde e habitação. A captação de recursos desse fundo vinha da contribuição de $0,5 \%$ da renda bruta das empresas públicas e privadas, que incluía instituições financeiras e seguradoras. Os recursos do FINSOCIAL deveriam ser administrados pelo BNDE e obrigatoriamente seriam vinculados aos projetos de natureza assistencial especificados pelo Decreto-Lei. Com essa nova atribuição, o nome do banco foi alterado para Banco Nacional de Desenvolvimento Econômico e Social BNDES. Já no primeiro ano, o FINSOCIAL respondia por mais de 13\% do total de recursos do BNDES.

Mas, em meio à crise, o BNDES deixou de lado suas atividades iniciais. A prioridade do governo era o ajuste macroeconômico, o controle da inflação e a necessidade de geração de superávits comerciais. Houve, segundo Tavares et al (2010), uma redefinição da atuação do banco com a volta ao investimento em infraestrutura - financiamento à construção da usina de ITAIPU - e o aumento da participação do setor agrícola nos desembolsos 
do BNDES. As aplicações do BNDES, que alcançaram 1,8\% do PIB em média no período entre 1974 e 1979, caiu para menos de 1\% do PIB em 1981 e apenas em 1984 recuperou seu patamar - ainda assim, por período muito breve. No final da década de 1980, os desembolsos do BNDES alcançavam apenas $0,5 \%$ do PIB.

Nesse cenário de desequilíbrio macroeconômico, com comprometimento dos recursos públicos para pagamento dos serviços das dívidas externa e interna, foram criadas uma série de mecanismos para controlar o repasse ao crédito rural. As Resoluções do BACEN n ${ }^{\circ}$ 671, de dezembro de 1980, e n ${ }^{0} 698$, de junho de 1981, limitaram o volume de crédito rural e introduziram a correção monetária no empréstimo, ampliaram as exigibilidades e aumentaram as taxas de juros. A tendência de queda do crédito rural só foi revertida em 1985 quando o governo corrigiu o Valor Básico de Custeio (VBC) e elevou os limites de financiamento dos principais produtos de consumo interno.

A crise fiscal também teve efeitos graves sobre o crédito habitacional. Os reajustes de ativos e dos passivos do SFH perderam sincronia ${ }^{44}$, levando à falência e extinção do Banco Nacional da Habitação em 1986, com consequente redução drástica do número de unidades financiadas. $\mathrm{O}$ ativo do $\mathrm{BNH}$ foi incorporado à Caixa Econômica Federal (CEF), que passou a ser a operadora exclusiva do FGTS. Contudo a CEF não dispunha de instrumentos de planejamento, articulação e formulação de políticas. Sem o BNH, o governo federal perdeu rapidamente a sua capacidade de gestão da política habitacional e seu investimento no setor tornou-se irrisório. Segundo Magnabosco (2011), o SFH, que chegou a atender $65 \%$ da demanda por novas moradias entre 1980 e 1982, atendeu menos de $10 \%$ da demanda habitacional entre os anos de 1983 a 1986. O volume médio anual de unidades financiadas caiu de 545 mil, no primeiro período, para apenas 82 mil, no segundo momento. Em 1989, o SFH financiou apenas 100 mil contratos de crédito para aquisição de moradias novas e imóveis usados.

A crise econômica também trouxe restrições ao uso dos recursos do FGTS como mecanismo de financiamento à habitação e ao saneamento básico. $\mathrm{O}$ aumento da taxa de desemprego entre 1981 e 1984 limitou o crescimento do volume das receitas do fundo e aumentou o volume dos saques, restringindo os recursos disponíveis à aplicação. Com a

\footnotetext{
${ }^{44}$ Para lidar com o descompasso, havia sido criado o Fundo de Compensação de Variações Salariais (FCVS). O FCVS cobria as diferenças entre ativos e passivos do sistema e era financiado por uma contribuição compulsória nas prestações de todos os mutuários. As prestações eram reajustadas com base na inflação passada a cada 12 meses e os saldos devedores eram corrigidos a cada 3 meses em sincronia com a correção dos saldos de caderneta de poupança. A aceleração da inflação tornou os recursos efetivos do FCVS insuficientes para cobrir os descompassos entre ativos e passivos e a cobertura passou a ser meramente contábil. O desequilíbrio se acumulou rapidamente e, em 1986, durante o Plano Cruzado, os saques das cadernetas de poupança reduziram ainda mais a disponibilidade de fundos para novos financiamentos. A insolvência do BHN foi inevitável.
} 
extinção do BNH, os recursos do FGTS foram redirecionados ao financiamento do saneamento por meio do Plano Nacional de Saneamento (Planasa). Contudo, problemas relacionados à gestão do fundo levaram esse programa à estagnação em fins dos anos 1980 .

A crise dos anos 1980 teve reflexos severos no crédito e no investimento. Entre 1975 e 1979, o investimento total apresentou taxa de crescimento de $10,0 \%$ ao ano. No período seguinte, entre 1979 e 1984, o investimento total teve queda anual de 5,7\%. A queda do investimento se estancou em meados da década, mas na média entre 1979 e 1989, a formação bruta de capital caiu $0,6 \%$ ao ano. Dez anos seguidos de restrição ao crédito provocaram uma retração grande do saldo de empréstimos ao setor privado: $8,4 \%$ ao ano. As quedas do investimento e do crédito também tiveram impactos na taxa de crescimento do PIB. Entre 1975 e 1979, a taxa de crescimento do PIB havia sido de 6,7\% ao ano. No período de 1979 a 1989, o crescimento do PIB caiu para 2,9\% ao ano, o que indica uma diminuição da taxa de crescimento econômico de 3,8 pontos percentuais. 


\section{Capítulo 5}

\section{As mudanças institucionais na economia brasileira desde 1990}

A crise dos anos 1980, como visto no capítulo anterior, desarticulou o crédito e afetou o investimento no país. A década de 1990 iniciou com a prioridade de estabilização da inflação. Foram implantados dois planos de estabilização, os quais tiveram impacto restritivo sobre o crédito e o investimento - Planos Collor I e II. Apenas em 1994, com o Plano Real, o governo conseguiu de fato controlar a inflação e fundou uma base mínima para a retomada do financiamento de longo prazo da economia.

Nesse período, foi iniciada uma série de reformas institucionais que buscavam recuperar o crédito e alavancar o investimento. Algumas das mudanças institucionais ocorridas a partir dos anos 1990 intencionaram a redução do risco dos bancos e dos credores no financiamento. Outras mudanças buscaram elevar o retorno do capital de setores econômicos específicos como forma de atrair investimentos e acelerar o processo de acumulação de capital. Esse conjunto de mudanças teve efeito em praticamente todos os setores de atividade econômica, criando as bases para o aumento do crédito e possibilitando a retomada do investimento e do crescimento econômico.

É importante observar que a leitura histórica desse período parte da visão de que as mudanças institucionais implantadas pelos governos foram motivadas e articuladas por grupos de interesse que buscavam recuperar sua condição econômica comprometida com a crise e ampliar suas oportunidades de negócios. Outras mudanças - como a abertura comercial, por exemplo - responderam a uma agenda internacional que colocava como precondições à renegociação da dívida externa de países em desenvolvimento mudanças institucionais de caráter liberal. Em qualquer desses casos, é fundamental entender as mudanças como resultado da articulação política entre grupos de interesse que, em momentos sociopolíticos particulares, criou as condições para as transformações.

Em algumas situações, as mudanças implantadas geraram as condições suficientes para a retomada do crédito ou do investimento. Em outras, isso não ocorreu. As instituições foram aprimoradas, ou substituídas, mas as condições suficientes para a recuperação econômica não foram imediatamente alcançadas. Há ainda o caso de mudanças institucionais que, ao privilegiar os interesses de alguns grupos, prejudicaram o de outros, pois as articulações para essas mudanças não priorizaram o bem comum nem objetivaram transforma- 
ções que levassem a ganhos universais. Essas mudanças levaram a redistribuições de riqueza na economia, com ou sem ganhos de crescimento econômico agregado.

A seção 5.1 traz as principais mudanças institucionais ocorridas nos anos 1990 e discute como elas afetaram o investimento na economia brasileira. As principais medidas institucionais implantadas nesse período foram: (i) o código de defesa do consumidor, que estabeleceu as relações de responsabilidade entre fornecedores e consumidores; (ii) a nova lei de licitações, que implantou um conjunto de regras mais firmes e transparentes para a compra ou contratação de serviços pela administração pública; (iii) a abertura comercial, que buscou diminuir o caráter protecionista, implicando uma maior exposição da indústria brasileira à competição internacional; (iv) a implantação do Mercosul, que criou uma zona de livre comércio entre Brasil, Argentina, Uruguai e Paraguai; (v) as privatizações, que visavam elevar a qualidade dos serviços, a rentabilidade dos serviços de utilidade pública e a capacidade de financiamento das empresas do setor - na época, em situação financeira ruim; (vi) as concessões públicas, que delegavam a prestação de serviços públicos à empresas privadas, com o objetivo de aumentar o investimento e a qualidade dos serviços prestados; (vii) a criação do Sistema Financeiro Imobiliário e da Lei de Alienação Fiduciária, que buscavam recuperar o financiamento habitacional e implantar um regime de maior proteção aos credores; (vii) a lei das telecomunicações, que estabeleceu um novo regime de concessão com o objetivo de ampliar os investimentos e a capacidade instalada, garantindo a prestação universal dos serviços com qualidade; e (viii) o marco regulatório do petróleo de 1997, que implantou a nova política energética nacional com objetivo de aproveitar as fontes de energia do país.

A seção 5.2 descreve as mudanças institucionais ocorridas na década seguinte. Nos anos 2000, as principais reformas institucionais implantadas foram: (i) a Lei de Responsabilidade Fiscal, que estabeleceu um novo conjunto de regras para as finanças públicas baseadas na responsabilidade na gestão fiscal; (ii) a Lei $\mathrm{n}^{0} 10.303$ de 2001, que reformou a Lei de Sociedades Anônimas; (iii) a Lei $n^{\circ} 10.931$, de 2004, que criou as figuras do incontroverso e do patrimônio de afetação, instrumentos que deram maior segurança aos credores e compradores de imóveis; (iv) a lei de parceria público-privada, que estabeleceu regras de cooperação com o objetivo de aumentar o investimento e a qualidade de serviços públicos e de utilidade; (v) o marco regulatório do setor aéreo, orientado a readequar a indústria de transporte aéreo; (vi) a chamada "Lei do Bem", que incentivou o investimento em pesquisa e desenvolvimento; (vii) a Lei de Falências, que passou a regular a recuperação judicial e 
extrajudicial da massa falida de empresas; (viii) o marco regulatório do saneamento, que estabeleceu diretrizes nacionais para o saneamento básico no país.

A seção 5.3 traz as mudanças institucionais mais relevantes de 2010 a 2013: (i) o Novo Marco Regulatório do Petróleo, que estabeleceu novas regras para exploração e produção de petróleo e gás natural na área da camada pré-sal; (ii) o novo código florestal, que estabeleceu normas gerais sobre a proteção da vegetação, a exploração florestal, o controle da origem dos produtos florestais e da prevenção de incêndios; e (iii) o marco regulatório dos portos, que instituiu o sistema de concessão e arrendamentos de portos a empresas privadas. $^{45}$

A seção 5.4 faz um balanço dessas medidas, apontando os setores de atividade econômica - agropecuária, mineração, indústria, habitação, comércio, serviços de utilidade pública, mercados de capitais, serviços prestados as famílias e empresas, bancos etc. - mais afetados por cada política. Nesse balanço, também é sumariado o modo pelo qual as mudanças institucionais afetaram a economia: se alteraram o risco dos credores e o custo de recuperação de garantias, permitindo uma expansão do crédito, ou se afetaram diretamente o retorno do capital dos setores econômicos, diminuído a ineficiência e alterando os estímulos ao investimento.

\subsection{Os anos 1990}

O Código Brasileiro de Defesa do Consumidor (CDC), estabelecido pela Lei $\mathrm{n}^{\circ}$ 8.078, de 11 de setembro de 1990, visou a proteção dos direitos dos consumidores e disciplinou as relações entre o fornecedor e o consumidor final. O CDC estabeleceu as linhas gerais de uma política de relações de consumo, os direitos básicos e a proteção à saúde e à segurança dos consumidores. Do lado dos fornecedores, o código instituiu a responsabilidade por vício dos produtos ou serviços. O código estabeleceu padrões de conduta, prazos e penalidades.

O CDC buscou preencher uma lacuna legislativa num mercado em que as relações comerciais eram tratadas de forma obsoleta e não traziam nenhuma proteção ao consumidor. Gerou importantes impactos nas empresas, pois o CDC impôs maior qualidade na fabricação e no atendimento aos consumidores. Os setores mais afetados foram a indústria manufatureira, o comércio, os serviços de utilidade pública e os serviços prestados às famílias e empresas.

\footnotetext{
45 Além dessas leis, vale destacar o Marco Regulatório da Mobilidade Urbana, criado pela Lei $\mathrm{n}^{\circ}$ 12.587, de 3 de janeiro de 2012, que poderá ter efeito de longo prazo nas questões de desenvolvimento urbano.
} 
O estabelecimento de regras rígidas de controle da qualidade dos produtos e serviços implicou um aumento de custo para os fornecedores, que tiveram que investir na melhoria da qualidade por meio de pesquisa e desenvolvimento. De outro lado, o não cumprimento das regras do CDC implicou pesados custos financeiros para as empresas. Dessa forma, o código alterou o retorno das empresas de forma distinta, reduzindo os ganhos nos segmentos que não conseguiam repassar os aumentos de custos aos consumidores. Claramente essa foi uma mudança que alterou a relação de preços de ativos entre setores, ao mesmo tempo em que, ao dar maior segurança ao consumidor, estimulou a demanda.

Outra mudança profunda no mercado de bens de consumo e de bens de capital foi a abertura comercial. O Brasil começou sua abertura comercial tardiamente em relação aos demais países da América Latina, como destacado por Morley, Machado e Pettinato (1999) e Bandeira (2002). O Chile e a Argentina foram os países pioneiros, os quais iniciaram suas reformas na segunda metade da década de 1970. Na época, as principais medidas adotas foram o corte de tarifas de importação, a redução da dispersão tarifária e das barreiras não tarifárias. O Brasil só iniciou suas reformas ao final da década de 1980 e início da década de 1990, já numa época que a abertura comercial era elencada como uma das precondições para a renegociação da dívida externa.

A abertura comercial, na maior parte dos países latino-americanos, foi formada por quatro medidas básicas ${ }^{46}$ : redução do nível médio das tarifas de importação; redução do grau de dispersão da estrutura de tarifas; redução das barreiras não-tarifárias e restrições quantitativas; e redução ou eliminação dos impostos sobre exportações. Junto a essas medidas houve políticas cambiais com o objetivo de manter a competitividade cambial. No caso do Brasil, as reformas começaram em 1988 com a eliminação das parcelas redundantes das tarifas. A partir de 1990, foram tomadas as seguintes medidas: redução generalizada de alíquotas e de sua dispersão, extinção das barreiras não-tarifárias, eliminação de regimes aduaneiros especiais e regime de câmbio com taxas flutuantes.

O objetivo da abertura comercial estava relacionado à estrutura protecionista existente até então. A elevada proteção teve efeitos negativos sobre a evolução, a diversificação e a competitividade das exportações em muitos setores da economia, em especial no setor manufatureiro. Segundo Bandeira (2002), a motivação da abertura comercial estava relacionada a reversão do viés contrário à exportação e a percepção de que vários setores, com

\footnotetext{
${ }^{46}$ Ver Edwards (1995), IDB (1996) e Bandeira (2002).
} 
destaque para o industrial, deveriam ser confrontados com a competição externa para aumentar a eficiência e reduzir custos para os consumidores.

O setor mais afetado com a abertura comercial foi o industrial, como já mencionado. Nesse caso, houve redução do retorno do capital em vários segmentos que, confrontados à competição externa, não conseguiram manter suas parcelas de mercado. O setor comercial também foi afetado de forma expressiva pela abertura, pois houve substancial ampliação e especialização do comércio internacional. As famílias perceberam o aumento do poder de compra com a queda de preços em alguns produtos.

O Mercosul (Mercado Comum do Sul) foi outra ação institucional que constituiu uma abertura comercial mais profunda com um conjunto pequeno de países. Criado pelo tratado de Assunção em 1991 entre Argentina, Brasil, Paraguai e Uruguai, o mercado comum implicava, a longo prazo, a livre circulação de bens, serviços e fatores produtivos entre os países e a eliminação dos direitos alfandegários e restrições não tarifárias à circulação de mercadorias. Inicialmente foi estabelecida uma zona de livre comércio, ou seja, uma área onde os países membros não tributavam ou restringiam as importações um do outro. A partir de 1995, foi estabelecida a união aduaneira, um mercado com tarifa externa comum: todos os países deveriam cobrar as mesmas alíquotas nas importações vindas dos países de fora do bloco. Em 1996, a Bolívia e o Chile entraram como associados ao Mercosul.

A criação do Mercosul trouxe uma ampliação do mercado consumidor para vários segmentos industriais e também uma ampliação da oferta de produtos, elevando a concorrência. Com a ampliação do mercado, as empresas puderam investir em ampliação da produção e aumento das exportações para os países membros. Para os consumidores, ampliouse a cesta de produtos disponíveis com efeito maior sobre a agropecuária e a indústria.

A Lei de Licitações - Lei no 8.666, de 21 de junho de 1993 - alterou as normas gerais sobre licitações e contratos administrativos de obras, serviços, compras, alienações e locações da União, dos estados, do Distrito Federal e dos municípios. As licitações passaram a ser classificadas em cinco modalidades de acordo com a Lei: concorrência, tomada de preços, convite ou carta convite, leilão e concurso. Posteriormente, com a lei $\mathrm{n}^{\mathrm{o}} 10.520 \mathrm{de}$ 2002, foi introduzida a modalidade de Pregão.

A principal mudança contida na Lei $\mathrm{n}^{\circ} 8.666$ teve como objetivo criar mecanismos para a seleção de fornecedores cujos serviços e custos fossem mais vantajosos para a administração pública. $\mathrm{O}$ artigo terceiro determinou que as propostas fossem processadas e julgadas de acordo com os seguintes princípios básicos: legalidade, impessoalidade, moralidade, igualdade, publicidade, probidade administrativa, vinculação ao instrumento convocató- 
rio, julgamento objetivo e os que lhes são correlatos. Implícita a esse conjunto de princípios está à ideia de economicidade, ou seja, a contratação dos bens ou serviços pelo menor preço, dada as condições técnicas e comerciais definidas no edital da licitação. A lei também buscava dar maior eficiência ao processo de compra e reduzir os custos de transação e a corrupção, inibindo o comportamento oportunista e a ação dos caçadores de renda ${ }^{47}$.

Essa mudança afetou diretamente o governo e as empresas, as quais tiveram que se adequar às novas regras. No caso das empresas, o elemento mais afetado foi o retorno, pois em muitas circunstâncias a indução do menor preço levou à concorrência predatória. $\mathrm{O}$ comportamento oportunista, de outro lado, não foi inibido na extensão que se imaginava e vários artifícios foram adotados para contornar a lei, desde acordos prévios de preço e aditamentos de contratos, até a piora da qualidade dos produtos e serviços entregues.

Outra importante mudança institucional que afetou a esfera pública foi a privatização. Esse processo correspondeu à desestatização de empresas públicas, as quais foram fortemente afetadas pela crise da dívida externa, a escassez de recursos no mercado internacional e a política anti-inflacionária do governo. $\mathrm{Na}$ América Latina, de acordo com Bandeira (2002), esse processo se deu de cinco maneiras: (i) venda de ações, com transferência de controle da empresa; (ii) oferta pública de ações no mercado acionário; (iii) compra de ações por empregados; (iv) liquidação da empresa e venda de seus ativos; e (v) concessão, muito empregado no caso de serviços de utilidade pública. Segundo IDB (1996), também havia outros objetivos que levaram à privatização, como a elevação da eficiência das empresas, o fortalecimento do balanço de pagamentos, a sustentação da estabilidade macroeconômica, a elevação do investimento, a promoção da competição, a melhoria da qualidade dos serviços oferecidos e o desenvolvimento do mercado de capitais. Assim como no caso da abertura comercial, a desestatização pertencia à agenda internacional de renegociação da dívida externa.

As empresas estatais tiveram papel fundamental no processo de industrialização do país. O Estado investiu em vários setores estratégicos para o desenvolvimento, desde a exploração de produtos primários, como a mineração (Vale do Rio Doce, Petrobras), até setores produtores de bens de capital (Embraer), passando também por áreas de energia e telecomunicações. Contudo, muitas empresas públicas começaram a ter problemas, com déficits orçamentários e restrições de crédito para investimento. A crise da dívida externa afetou

\footnotetext{
${ }^{47}$ Segundo a teoria dos caçadores de renda, os agentes econômicos buscam a maximização de bem estar dentro de um conjunto determinado de regras ou mesmo fora dele. A obtenção dessa renda pode implicar transferências dentro da sociedade. Ver Krueger (1974), Tullock $(1967,1990)$ e Silva (1997a, 1997b).
} 
a capacidade do Estado financiar essas empresas, ao mesmo tempo em que ocorria um aumento forte da demanda pelos serviços, principalmente em energia e telecomunicação.

Paralelamente ao processo de privatização, foi criada uma lei específica para contratos de concessão e permissão - Lei $n^{\circ} 8.987$, de 13 de fevereiro de 1995. A lei definiu três tipos de contratação: (i) a concessão de serviço público; (ii) a concessão de serviço público precedida da execução de obra pública; e (iii) a permissão de serviço público. ${ }^{48} \mathrm{~A}$ lei também definiu a remuneração pelos serviços, a qual passou a ser feita na forma de tarifas. A forma de contratação dos serviços passou a ser feita por meio de licitação na modalidade concorrência.

As tarifas do serviço concedido eram fixadas pelo preço da proposta vencedora da licitação. Mas, os contratos previam mecanismos de revisão das tarifas, de forma a garantir o equilíbrio econômico-financeiro das concessionárias. De forma geral, os contratos garantiam retornos seguros. As tarifas eram diferenciadas em razão de características técnicas e de custos específicos devido ao atendimento de distintos segmentos de usuários.

As concessões e as privatizações afetaram principalmente os setores de serviços de utilidade pública e serviços prestados as famílias e empresas. As empresas prestadoras dos serviços aumentaram os investimentos nos setores de energia elétrica, distribuição de gás, saneamento, telecomunicações e rodovias, áreas antes operadas prioritariamente por estatais. Indiretamente, a indústria manufatureira foi afetada, na medida em que as tarifas elevaram o custo de produção - principalmente no caso de energia. As obras previstas nas concessões públicas (construção de rodovias, hidrovias, portos, etc.), por sua vez, beneficiaram as atividades de construção civil.

O Sistema Financeiro Imobiliário (SFI) foi criado, em 1997, pela Lei no 9.514 de 20 de novembro de 1997, como complemento ao Sistema Financeiro da Habitação (SFH), o qual passava por uma profunda crise. O SFH já havia passado por uma importante reestruturação em 1986, com a extinção do BNH, quando suas funções foram redistribuídas entre vários órgãos públicos. Contudo, a aceleração da inflação e a instabilidade macroeconômica

\footnotetext{
${ }^{48}$ A concessão de serviço público corresponde à delegação de prestação do serviço para a empresa priva$\mathrm{da}$, que tenha capacidade para o seu desempenho, por sua conta e risco e por prazo determinado. Essa delegação é feita por meio de licitação, na modalidade de concorrência. A concessão de serviço público precedida da execução de obra pública corresponde à delegação de construção, conservação, reforma ou ampliação de obras de interesse público a empresa privada que tenha capacidade para o seu desempenho, por sua conta e risco e por prazo determinado. A delegação é feita por meio de licitação, na modalidade de concorrência. $\mathrm{O}$ contrato de exploração permite que o investimento da empresa concessionária seja remunerado e amortizado mediante a exploração do serviço ou da obra por prazo determinado. E a permissão de serviço público corresponde à delegação a título precário, mediante licitação, da prestação de serviços públicos, feita pelo poder concedente à pessoa física ou jurídica que demonstre capacidade para seu desempenho, por sua conta e risco.
} 
nas décadas de 1980 e 1990 pioraram a situação, pois parte substantiva dos fundos não voltou ao sistema nos prazos e valores previstos.

O objetivo do SFI era promover o financiamento imobiliário em geral. Seus fundamentos principais eram: (i) a securitização dos créditos imobiliários e (ii) uma maior segurança dos contratos. A securitização de créditos imobiliários é a operação pela qual tais créditos são expressamente vinculados à emissão de uma série de títulos, mediante o Termo de Securitização de Créditos, lavrado por uma companhia securitizadora. Os principais instrumentos para securitização são: (i) os Certificados de Recebíveis Imobiliários (CRI) ${ }^{49}$; (ii) as Letras de Crédito Imobiliário (LCI); e (iii) as Cédulas de Crédito Imobiliário (CCI). Diferentemente do SFH, a captação de recursos do SFI se daria via mercado. A securitização visava a criação de um mercado secundário de hipotecas por meio da venda de frações ideais de carteiras hipotecárias com risco diluído pela diversificação.

A segurança jurídica dos contratos do SFI seria garantida pela introdução da alienação fiduciária. A alienação fiduciária é o contrato jurídico pelo qual o devedor transfere ao credor a propriedade do imóvel como garantia durante o período de pagamento do principal da dívida. Até a quitação do bem, o banco é o proprietário direto do imóvel e o comprador tem a posse do imóvel. Com o pagamento da dívida e seus encargos, a propriedade do imóvel é transferida ao comprador. Caso a dívida seja vencida e não paga, na totalidade ou em parte, a propriedade do imóvel permanece com o banco. O imóvel vai a leilão e o valor da venda paga a dívida e as despesas com o processo jurídico e o que sobrar é devolvido ao tomador do crédito, como na execução de hipotecas. Vale destacar que o instrumento da alienação fiduciária não é restrito aos contratos de financiamento imobiliário, podendo ser utilizada em qualquer contrato de compra e venda em que o bem constitui garantia real do empréstimo (automóveis, por exemplo).

A criação do SFI e a introdução da alienação fiduciária afetaram diretamente dois setores: habitação e bancos e mercado de capitais. Para os bancos a nova instituição aumentou a segurança nos contratos de financiamento, reduzindo o risco do contrato. No âmbito do setor habitacional houve uma pequena ampliação de recursos para financiamento, já que o sistema possibilitou a captação de recursos via mercado. Contudo, o SFI é um caso de mudança institucional que não gerou as condições suficientes para mudança imediata de comportamento dos mercados e teve efeito pequeno sobre o investimento. As altas taxas de juros do final da década de 1990 e os entraves institucionais e jurídicos que ainda permea-

${ }^{49}$ O CRI é um título de crédito nominativo, de livre negociação, lastreado em créditos imobiliários, constitui uma promessa de pagamento em dinheiro e é de emissão exclusiva das companhias securitizadoras. 
vam o setor habitacional impediram que o SFI tivesse resultados expressivos, com exceção ao financiamento de edificações comerciais. A alienação fiduciária, por outro lado, teve sucesso imediato no ramo de financiamento a automóveis, modelo de garantia que se mantém até hoje.

O marco regulatório do petróleo foi instituído pela Lei ${ }^{\circ} 9.478$ de 6 de agosto de 1997. Essa lei dispôs sobre a política energética nacional, as atividades relativas ao monopólio do petróleo e criou o Conselho Nacional de Política Energética (CNPE) e a Agência Nacional do Petróleo (ANP). A política energética nacional teve como meta o aproveitamento racional das fontes de energia. Mais especificamente, essa política buscou ${ }^{50}$ : (i) promover o desenvolvimento, a ampliação do mercado de trabalho e a valorização dos recursos energéticos; (ii) proteger os interesses do consumidor com relação a preço, qualidade e oferta dos produtos; (iii) proteger o meio ambiente; (iv) promover a livre concorrência; (v) atrair investimentos na produção de energia; e (vi) ampliar a competitividade do país no mercado internacional.

Dentre os objetivos do CNPE estavam: (i) a formulação de políticas nacionais para a promoção do aproveitamento racional dos recursos energéticos do país; (ii) o estabelecimento de diretrizes para a importação e exportação; e (iii) a definição das estratégias e política de desenvolvimento econômico e tecnológico da indústria de petróleo e de seus derivados. A ANP foi formada como uma entidade integrante da administração federal indireta para atuar como órgão regulador da indústria do petróleo, gás natural, e seus derivados.

A Lei n ${ }^{0} 9.478$ de 1997 definiu ainda o processo de exploração, desenvolvimento e produção de petróleo e de gás natural. Estabeleceu-se que o processo deveria ser feito mediante contratos de concessão, precedidos de licitação. No contrato de concessão, as atividades de prospecção, exploração e produção de petróleo são realizadas por conta e risco do concessionário. Caso haja uma nova descoberta e as atividades de exploração sejam desenvolvidas, o petróleo e o gás natural extraído só passariam para a propriedade dos concessionários após o pagamento de royalties e outras participações governamentais.

O marco regulatório de 1997 adotou o sistema de concessão para garantir o retorno das empresas que assumiriam o alto risco de exploração do petróleo e seus derivados. Essas medidas afetaram diretamente o setor de mineração do petróleo e gás, diminuindo o risco de negócio, aumentando o retorno efetivo dos investidores e, portanto, incentivando o investimento. Além disso, a ANP afetou as empresas consumidoras de energia e as famílias, pas-

\footnotetext{
${ }^{50}$ Para maiores detalhes, consultar a Lei no 9.478 de 6 de agosto de 1997.
} 
sando a regular um mercado que antes era norteado pela atuação do poder executivo e da Petrobras.

Os dados da Petrobras ilustram o efeito sobre o investimento. Na média do período 1995 a 1997, o investimento da Petrobras foi de R \$ 7,658 bilhões por ano. Após a mudança institucional, o investimento ampliou-se, registrando média de $\mathrm{R} \$ 21,910$ por ano nos dez anos seguintes. A ampliação dos investimentos teve reflexo sobre a produção. Segundo Ministério de Minas e Energia (2014), a taxa de crescimento da produção brasileira de petróleo passou de 4,1\% ao ano, na média dos dez anos anteriores ao Marco Regulatório do Petróleo de 1997, para uma taxa anual de expansão de 7,6\% ao ano nos dez anos seguintes. O setor de gás natural teve uma ampliação menor, seja dos investimentos, seja da produção. A taxa média de crescimento da produção brasileira de gás natural passou de 5,4\% ao ano, entre 1987 e 1997, para uma taxa anual de expansão de 6,3\% ao ano entre 1997 e 2007.

\section{Gráfico 5.1 Investimentos da Petrobras, R\$ bilhões*}

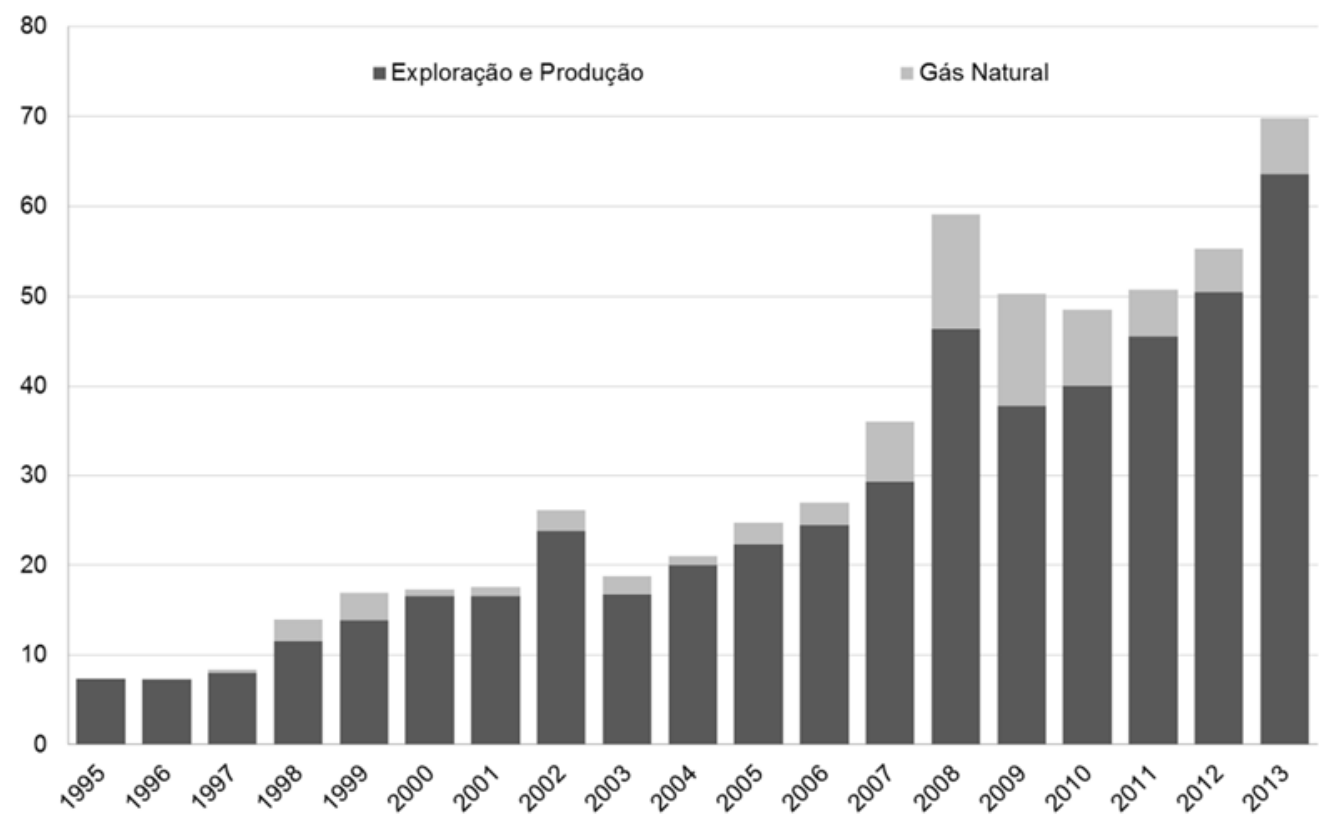

Fonte: Petrobras. (*) valores a preços 2014 deflacionados pelo IGP-DI.

Antes do estabelecimento da nova Lei das Telecomunicações em 1997, os serviços atingiam apenas uma pequena parcela da população, restringindo-se à área urbana (98\% das linhas telefônicas) e as famílias das classes "A" e "B" (80\% das linhas telefônicas). Essa situação foi resultado da incapacidade de manutenção do investimento no setor após a crise da dívida externa, o que levou a uma expansão da oferta insuficiente para acompanhar a demanda - criando, obviamente, uma situação de racionamento de mercado.

Uma das razões da falta de investimento era a questão das tarifas. As tarifas eram estabelecidas de forma dissociada dos custos dos serviços, o que levou as concessionárias a 
não realizar os investimentos necessários à expansão da rede e à melhoria da qualidade. $\mathrm{O}$ mesmo ocorrera com o Sistema Telebrás, cujas tarifas eram definidas pelo Governo Federal, mais preocupado em conter o processo inflacionário no final dos anos 1980 e início dos 1990, do que compatibilizar as tarifas ao custo. Além disso, a acomodação do setor pode ser resultado do monopólio: sem competição, as empresas não eram estimuladas a buscar soluções inovadoras para ampliar o atendimento da demanda, reduzir do custo ou melhorar a qualidade.

A Lei $\mathrm{n}^{\circ}$ 9.472, de 16 de julho de 1997, buscou mecanismo para a reversão desse quadro de incapacidade de atendimento à demanda e de falta de investimento. A lei dispôs sobre a organização dos serviços de telecomunicações e criou um órgão regulador para o setor - a Agência Nacional de Telecomunicações (ANATEL). O órgão adotou as medidas necessárias para o atendimento do interesse público e para o desenvolvimento das telecomunicações.

De acordo com a lei, os serviços de telecomunicações em regime público ${ }^{51}$ eram prestados mediante concessão ou permissão, com atribuição à sua prestadora de obrigações de universalização e de continuidade. A ANATEL passou a regular a prestação desses serviços de modo que: (i) possibilitasse o acesso de qualquer pessoa ao serviço de telecomunicações, independentemente do local de residência e de sua condição socioeconômica; e (ii) possibilitasse a continuidade dos serviços aos usuários de forma adequada e sem interrupções não justificadas.

O regime de concessão dos serviços de telecomunicações, de acordo com a Lei $\mathrm{n}^{\circ}$ 9.472/1997, se deu por meio da delegação da prestação dos serviços estabelecido em contrato. Nesse contrato foram determinados: (i) o prazo; (ii) as obrigações da concessionária de arcar com os riscos empresariais; e (iii) a remuneração, por meio de tarifas cobradas dos usuários. As concessões não teriam caráter de exclusividade e as tarifas deveriam seguir a estrutura proposta pela agência reguladora, fixadas no contrato de concessão.

A lei das telecomunicações estabeleceu o novo regime de concessão dos serviços de telecomunicação, quebrando o monopólio estatal. Dessa forma, houve um aumento da oferta, com o aumento das empresas prestadoras e da qualidade geral dos serviços. Essa nova base institucional afetou os setores de serviços prestados às famílias e às empresas, assim como as atividades de serviços de utilidade pública. O novo regime permitiu o aumento do investimento, com a expansão da rede instalada e efeitos sobre toda a economia, pois o re-

\footnotetext{
${ }^{51}$ Estão no regime público a prestação de serviços de telecomunicações de interesse coletivo, ficando de fora a prestação de serviços de interesse restrito.
} 
torno das concessionárias foi garantido pelas tarifas reguladas. Conforme ilustra o Gráfico 5.2, o investimento elevou-se de forma considerável após a introdução do novo marco em 1997. Contudo, a maior parte dos investimentos em expansão das redes e dos serviços deuse nos primeiros quatro anos após a mudança de regime. Em 2002, os investimentos voltaram para o patamar de 1995, crescendo vagarosamente desde então.

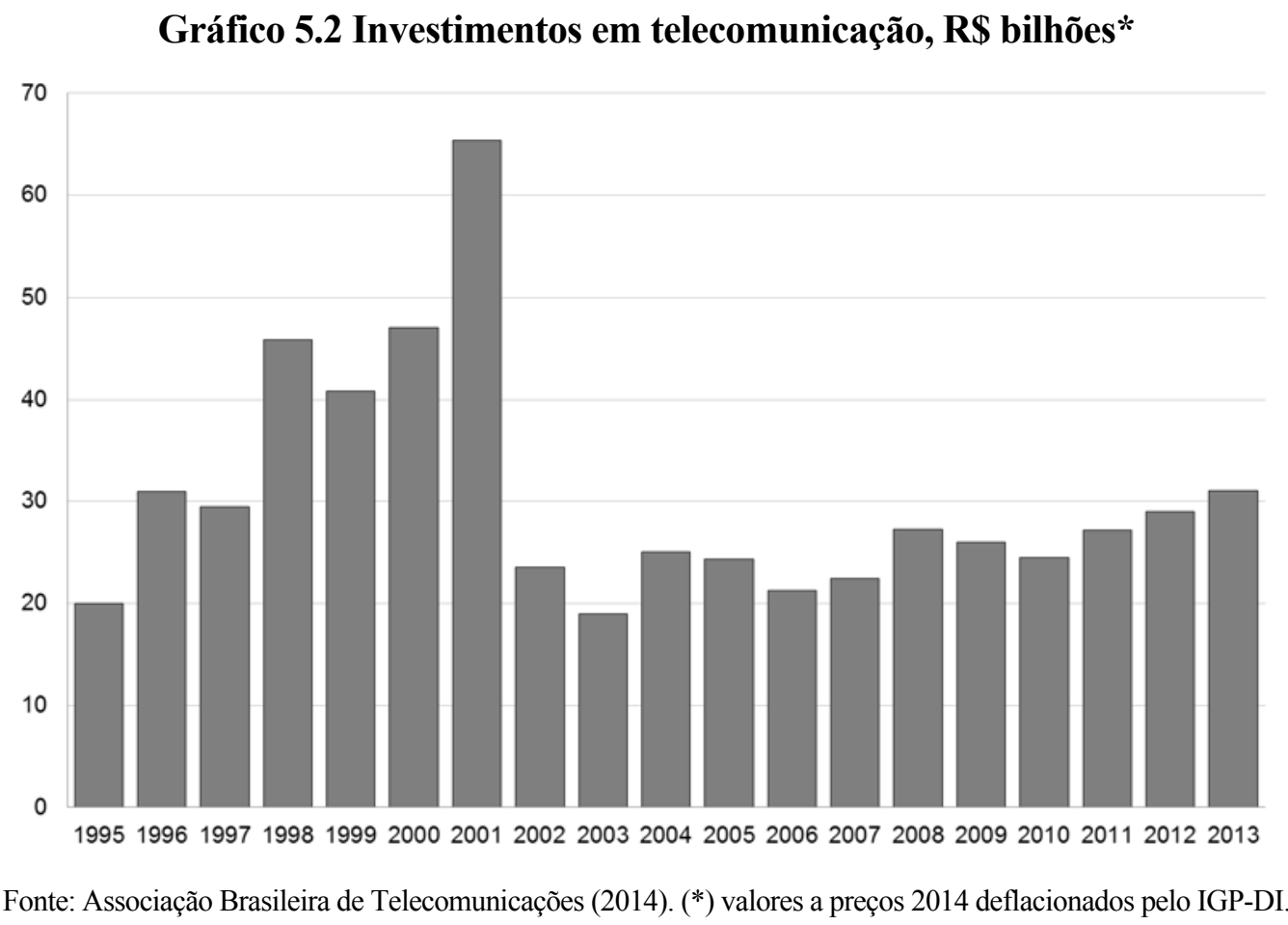

\subsection{Os anos 2000}

A Lei de Responsabilidade Fiscal, ou Lei Complementar $n^{0}$ 101, de 4 de maio de 2000, estabeleceu um conjunto de regras para as finanças públicas visando a responsabilidade na gestão fiscal, com controles de gastos públicos, os quais passaram a ser condicionados à capacidade de arrecadação de tributos de cada ente público (municípios, unidades da Federação e União). A responsabilidade na gestão fiscal implicava ações planejadas e transparentes com o intuito de prevenir riscos e corrigir desequilíbrios das contas públicas. Para atingir esses objetivos, as metas estabelecidas de resultados fiscais deveriam ser cumpridas, o que limitava uma série de componentes das receitas e despesas, tais como: (i) renúncia de receita; (ii) geração de despesas com pessoal, de seguridade social e outras; (iii) dívidas consolidada e mobiliária; (iv) operações de crédito, inclusive por antecipação de receita; (v) concessão de garantia; e (vi) inscrição em restos a pagar.

De acordo com a lei, as finanças devem ser apresentadas em detalhes ao Tribunal de Contas (da União, dos estados ou dos municípios). Esses órgãos devem julgar as contas e 
caso elas sejam rejeitadas, deve ser instaurada uma investigação, podendo resultar em multas ou na proibição de disputa em novas eleições.

A Lei de Responsabilidade Fiscal inovou, na medida em que introduziu vários limites de gastos, seja para as despesas do exercício, seja para o grau de endividamento. O estabelecimento de metas e prioridades na alocação das despesas passou a ser regido pela Lei de Diretrizes Orçamentárias (LDO), também instituída pela Lei Complementar n ${ }^{\circ} 101$, de 4 de maio de 2000. A LDO dispôs sobre: (i) o equilíbrio entre as receitas e as despesas; (ii) os critérios e a forma de limitação de empenho; (iii) as normas relativas ao controle de custos e à avaliação dos resultados dos programas financiados com recursos dos orçamentos; e (iv) as demais condições e exigências para transferências de recursos a entidades públicas e privadas.

A Lei de Responsabilidade Fiscal foi criada para inibir o desperdício de recursos e o descontrole fiscal, principalmente nos estados e municípios brasileiros. Além disso, pretendia-se inibir práticas como a de gestores públicos que promoviam, como manobra política, obras de grande porte no final de mandatos, deixando a conta para os sucessores. Na nova base institucional, os gastos públicos foram controlados por meio do estabelecimento de metas e regulação dos Tribunais de Contas (da União, estados e municípios).

Essa medida afetou principalmente a oferta de bens públicos, limitando os gastos com investimentos do setor público, os quais passaram a ter um regime mais rígido de endividamento. Com o maior controle dos gastos, foi possível reduzir os desequilíbrios das despesas públicas, diminuindo o risco de não pagamento das dívidas. Isso teve um efeito de longo prazo positivo sobre a oferta de crédito, mas no curto prazo, vários governos estaduais e municipais, ou empresas estatais ligadas a eles, ficaram sem capacidade de endividamento, limitando a demanda por crédito.

Em outubro de 2001, a Lei $n^{\circ} 10.303$ reformou a Lei das Sociedades Anônimas, procurando propiciar aos acionistas minoritários a redução de riscos e ampliar a sua participação no controle das empresas de capital aberto. A ideia fundamental da lei era tornar o mercado de capitais brasileiro acessível a pequenos investidores e, assim, diminuir sua concentração em grandes investidores.

Essa lei veio reforçar o impulso dado com a criação, em 2000, do chamado Novo Mercado pela Bolsa de Valores de São Paulo. O novo mercado, inspirado no Neuer Market alemão, introduziu regras que firmaram um novo padrão de governança corporativa, com grau de transparência bem mais elevado. No Novo Mercado, as companhias só podem emitir ações com direito de voto e todos os acionistas têm de vender suas ações pelo mesmo 
preço que o acionista principal em caso de venda de controle. Se o controlador decidir sair do mercado, a empresa fica obrigada a fazer oferta pública para recomprar as ações de todos os acionistas pagando, no mínimo, o valor econômico. As empresas do Novo Mercado devem manter no mínimo $25 \%$ das ações em circulação e o seu Conselho de Administração deve ser composto por no mínimo cinco membros, sendo $20 \%$ dos conselheiros independentes e o mandato máximo de dois anos. A maior transparência foi garantida com a exigência de divulgação de dados financeiros mais completos, relatórios trimestrais com demonstração de fluxo de caixa, relatórios consolidados revisados por auditor independente e relatórios financeiros anuais em padrão internacional. A companhia também é obrigada a divulgar mensalmente as negociações com valores mobiliários da empresa pelos diretores, executivos e acionistas controladores.

Essas mudanças ${ }^{52}$ deram um grande impulso ao mercado acionário brasileiro, que teve papel de destaque na captação de recursos para o investimento de 2002 em diante. Um número expressivo de empresas abriu seu capital, captando recursos para vários setores de atividade econômica, entre os quais se destacaram os de: construção civil (construtoras e incorporadoras), agroindústria (frigoríficos e usinas de açúcar e álcool), geração e distribuição de energia elétrica e financeiro (bancos múltiplos e seguradoras). ${ }^{53}$ Contudo, a crise financeira mundial de 2008 prejudicou a captação de fundos por esses mecanismos, limitando o papel do mercado acionário como mecanismo de financiamento do investimento nos últimos anos.

A Lei $n^{0} 10.931$, de 02 de agosto de 2004, também conhecida como lei do incontroverso dispôs sobre o patrimônio de afetação de incorporações imobiliárias e o valor do incontroverso e criou a Letra de Crédito Imobiliário, a Cédula de Crédito Imobiliário e a Cédula de Crédito Bancário.

A regra do patrimônio de afetação consistiu na separação entre os bens e direitos das empresas de construção e incorporação imobiliária dos patrimônios dos empreendimentos que essas empresas promovem. Com isso, os empreendimentos passaram a ter a sua própria contabilidade, separada das operações da incorporada ou construtora, o que deu maior segurança aos compradores, garantindo seu patrimônio e a destinação dos recursos aplicados

\footnotetext{
52 A Lei no 11.638 de 2007 estedeu às sociedades de grande porte disposições relativas à elaboração e divulgação de demostrações financeiras, reforçando a transparência nos mercados.

${ }^{53}$ No caso da construção civil, os recursos foram fundamentais para as empresas adquirirem terrenos que foram empregados em empreendimentos imobiliários lançados de 2005 em diante.
} 
exclusivamente nas obras do imóvel adquirido. A redução do risco, sem dúvida, elevou a disposição a investir em imóveis.

A regra do incontroverso buscou, na mesma linha, reduzir o risco dos bancos. Anteriormente, havia a possiblidade jurídica de controvérsia com relação aos valores devidos por um mutuário ao banco no caso de crédito imobiliário. O mutuário abria um processo questionando a inconstitucionalidade do pagamento de juros nominais superiores a $12 \%$ ao ano e, durante o processo, deixava de recolher suas obrigações, o que comprometia o fluxo de recebimentos dos bancos. Ao final do processo, que transitava por 10 ou 15 anos, os bancos ganhavam a causa, mas o valor residual do imóvel não era suficiente para cobrir a dívida e seus custos financeiros, incorrendo em prejuízos. Mesmo sabendo que no futuro perderia o imóvel, alguns mutuários viviam sem custos por um período suficiente para valer a pena a estratégia. A recorrência desse comportamento acabou reduzindo a disposição a emprestar dos bancos.

Nesse contexto, a lei determinou que, apesar de haver o entendimento de alguns juízes de que é cabível o questionamento da cobrança de juros nominais acima de $12 \%$ ao ano, deixou de ser possível o questionamento do valor do principal da dívida contratada. Além disso, o proponente da causa deveria continuar com os pagamentos de suas obrigações durante o andamento do processo, incluindo a amortização do principal da dívida, o IPTU do imóvel e, quando cabível, a taxa de condomínio. Isso reduziu os estímulos ao comportamento oportunista de mutuários que viam grandes vantagens em tomar o crédito e, na sequência, questionar a dívida.

O número de causas judiciais com intenções oportunistas caiu de forma considerável com essa mudança nos incentivos, reduzindo drasticamente a taxa inadimplência dos contratos. O número de contratos do Sistema de Financiamento Habitacional (SFH) que tinham atraso de mais de três mensalidades passou de $28 \%$ do total, no início de 2002, para 7\%, ao final de 2010, segundo dados do Banco Central do Brasil. Em termos absolutos, o número caiu de 124 mil para 60 mil contratos inadimplentes. Não foi a zero porque boa parte dos 60 mil inadimplentes em 2010 ainda era de mutuários com processos antigos em tramitação.

A Letra de Crédito Imobiliário e a Cédula de Crédito Imobiliário são títulos lastreados por créditos imobiliários que, por sua vez, são garantidos por hipoteca ou por alienação fiduciária de coisa imóvel. A Cédula de Crédito Bancário também é um título de crédito em favor de instituição financeira que representa promessa de pagamento decorrente de opera- 
ção de crédito, de qualquer modalidade. Esses instrumentos foram criados pela Lei $\mathrm{n}^{\mathrm{o}}$ 10.931 com o objetivo de incentivar o mercado de crédito imobiliário no Brasil.

Assim, a nova lei afetou os bancos e o mercado de capitais, dando maior segurança nos financiamentos imobiliários e aumentando a oferta de crédito. A nova lei também afetou esse mercado, porque deu maior garantia aos compradores de imóvel. Dessa forma, a nova instituição afetou o investimento por duas vias: (i) com aumento da oferta de crédito, associado à redução do risco dos bancos e das despesas de recuperação de colaterais e (ii) com aumento da demanda por imóveis e do retorno dos investidores. $\mathrm{O}$ reflexo sobre o segmento de edificações foi enorme, conforme ilustra o Gráfico 5.3 que traz o número de unidades financiadas pelo SFH em cada ano.

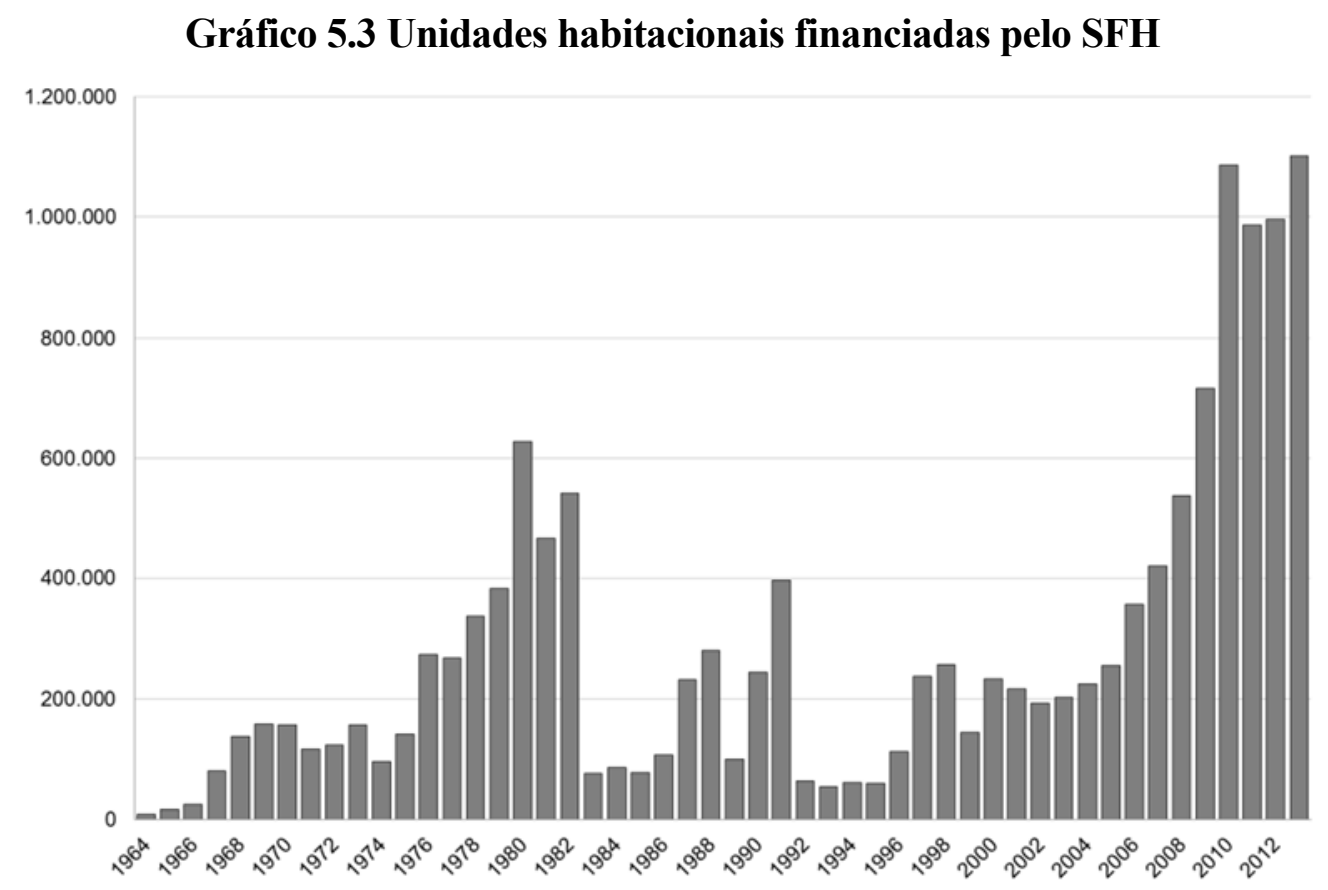

Fonte: Banco Nacional da Habitação e Caixa Econômica Federal.

A parceria público-privada (PPP) foi instituída pela Lei $\mathrm{n}^{\circ} 11.079$, de 30 de dezembro de 2004. De acordo com essa lei, a PPP foi definida como um contrato administrativo de concessão que pode ser feito na modalidade patrocinada ou administrativa. As PPP são distintas da concessão comum, regida pela Lei ${ }^{0}$ 8.987, de 13 de fevereiro de $1995 . \mathrm{Na}$ modalidade de concorrência, a contratação da PPP também é regida por licitação, como ocorre na concessão comum. A concessão patrocinada, por sua vez, é a delegação de serviços públicos, ou de obras públicas, nos casos em que as tarifas cobradas dos usuários não são suficientes para compensar os investimentos realizados pelo parceiro privado. O poder público complementa a remuneração da empresa privada com aportes regulares de recursos orçamentários (contraprestações do poder público), em adição às tarifas cobradas dos usuá- 
rios. A concessão administrativa é o contrato de prestação de serviços em que a administração pública é a usuária direta ou indireta. Nesse caso, não é possível ou conveniente a cobrança de tarifas dos usuários de tais serviços. A remuneração da empresa privada é integralmente proveniente de aportes regulares de recursos orçamentários do poder público.

O primeiro setor a se beneficiar com as PPP foi o de transportes. Além das tradicionais concessões rodoviárias, nos últimos anos houve ampliação dos investimentos por PPP nessa. Em 2012, o Governo Federal lançou o Programa de Investimentos em Logística (PIL), que prevê um volume grande de investimentos em rodovias, ferrovias, aeroportos e portos realizados por parcerias público-privadas. No setor aeroportuário, o leilão de concessão dos aeroportos federais do Galeão (RJ) e de Confins (MG) foram realizados em novembro de 2013 e os grupos vencedores assumiram a administração dos aeroportos em agosto de 2014. As obras nos dois aeroportos que já estavam em licitação, contratadas ou em andamento na ocasião do leilão continuaram como responsabilidade da Infraero, mas ampliações serão de responsabilidade dos parceiros privados. ${ }^{54}$

Exemplos recentes mostram a o potencial de diversificação das PPP para outras áreas de atividade. Entre 2011 e 2014, o Governo do Distrito Federal (GDF) deu terras públicas como contrapartida para dois grandes empreendimentos imobiliários. Num dos casos, o empreendimento habitacional Jardins Mangueiral, pertencente ao Programa Minha Casa Minha Vida, o GDF entrou com a doação do terreno e concedeu os serviços de manutenção da área por dez anos para a empresa parceira. A empresa, por sua vez, construiu os imóveis e os vendeu com custo reduzido. No segundo caso, o GDF, doou uma área para edificação habitacional em contrapartida da construção de uma ponte sobre o Lago Paranoá na região norte de Brasília.

Outro caso inovador foi a PPP do Complexo Penitenciário de Ribeirão das Neves em Minas Gerais. O governo do Estado entrou com o terreno para o complexo penitenciário e o parceiro privado desenvolveu o projeto, escolheu a tecnologia de construção e de gestão, construiu o presídio e ficou incumbido da gestão do complexo penitenciário, mediante o

\footnotetext{
${ }^{54}$ Além disso, o funcionamento do setor da aviação civil foi afetado pela Lei $\mathrm{n}^{\mathrm{o}} 11.182$, de 27 de setembro de 2005 , que criou a Agência Nacional de Aviação Civil (ANAC) com o objetivo de regular e fiscalizar as atividades de aviação civil e de infraestrutura aeronáutica e aeroportuária. A ANAC tornou-se responsável pela ordem econômica do setor e pelo desenvolvimento e fomento da aviação civil, da infraestrutura aeronáutica e aeroportuária. Ela foi incumbida de estabelecer: (i) o regime tarifário da exploração da infraestrutura aeroportuária; (ii) as normas e os padrões mínimos de segurança de voo, desempenho e eficiência a serem cumpridos pelas prestadoras de serviços aéreos e de infraestrutura; (iii) o Sistema de Investigação e Prevenção de Acidentes Aeronáuticos (SIPAER) e (iv) a repreensão de infrações à legislação e quanto aos direitos dos usuários.
} 
pagamento mensal por preso, realizado pela Secretaria de Segurança Pública, e um bônus por desempenho. ${ }^{55}$

A chamada "Lei do Bem" - Lei n¹1.196/2005 - criou incentivos fiscais às empresas para a realização de pesquisa e desenvolvimento de inovação tecnológica. Ela instituiu o Regime Especial de Tributação para a Plataforma de Exportação de Serviços de Tecnologia da Informação (REPES), o Regime Especial de Aquisição de Bens de Capital para Empresas Exportadoras (RECAP) e o Programa de Inclusão Digital. A lei previu uma série de incentivos fiscais, os quais permitiram a dedução do lucro líquido da despesa com aquisição de bens utilizados para a pesquisa e o desenvolvimento de tecnologia, reduzindo o imposto de renda pago por elas ${ }^{56}$.

O REPES isentou o PIS/Pasep, a Cofins, o PIS/Pasep-Importação e a CofinsImportação, no caso da venda ou da importação de bens novos destinados ao desenvolvimento de software e de serviços de tecnologia da informação no Brasil. O RECAP também suspendeu a exigência das mesmas contribuições anteriores no caso de venda ou de importação de máquinas, aparelhos, instrumentos e equipamentos de empresas exportadoras.

No caso do programa de inclusão digital, houve isenção das alíquotas do PIS/Pasep e da Cofins incidentes sobre a receita bruta de venda a varejo de uma série de produtos, tais como unidades de processamento digital, máquinas automáticas para processamento de dados, teclado e mouse, modems, telefones portáteis de redes celulares que possibilitem o acesso à internet em alta velocidade do tipo smartphone e roteadores digitais.

Essa mudança institucional incentivou investimentos em inovação, afetando toda a economia. Neste caso, diferentemente das mudanças institucionais que afetam o retorno do negócio ou o risco de crédito, os incentivos tiveram impactos diretamente no custo do investimento realizado por empresas, governos e famílias. Conforme será analisado no Capítulo 7, o segmento de equipamentos de eletrônicos foi, ao lado da produção de derivados de petróleo e de celulose e papel, um dos setores industriais que verificou expansão elevada do

\footnotetext{
55 O governo acompanha 380 critérios de desempenho estabelecidos para medir a qualidade dos serviços prestados pelo parceiro privado e, com base neles, define a bonificação do prestador de serviço.

${ }^{56}$ Mais especificamente os incentivos fiscais são: (i) dedução do lucro líquido do valor equivalente à soma dos dispêndios realizados no período com pesquisa tecnológica e desenvolvimento de inovação; (ii) redução de $50 \%$ do Imposto sobre Produtos Industrializados (IPI) incidente sobre equipamentos, máquinas, aparelhos e instrumentos, destinados à pesquisa e ao desenvolvimento tecnológico; (iii) depreciação integral de máquinas, equipamentos, aparelhos e instrumentos, novos, destinados à utilização nas atividades de pesquisa tecnológica e desenvolvimento de inovação tecnológica, para efeito de apuração do IRPJ e da CSLL; (iv) amortização acelerada, mediante dedução como custo ou despesa operacional dos dispêndios relativos à aquisição de bens intangíveis, vinculados exclusivamente às atividades de pesquisa tecnológica e desenvolvimento de inovação; (v) redução a zero da alíquota do imposto de renda retido na fonte nas remessas efetuadas para o exterior destinadas ao registro e manutenção de marcas, patentes.
} 
investimento entre 2005 e 2009 (média de 9,3\% ao ano). Além disso, vale destacar que esses investimentos, além de expandir a acumulação de capital, possivelmente tiveram efeitos sobre a produtividade da economia.

A Lei de Falências - Lei n 11.101 , de 9 de fevereiro de 2005 - passou a regular a falência e a recuperação judicial e extrajudicial. Ela substituiu o Decreto-lei $n^{\circ} 7.661$ de 1945 nas questões que se referem ao processo de insolvência das empresas e criou a figura jurídica da recuperação judicial em lugar da antiga concordata.

A recuperação judicial tem por objetivo viabilizar a superação da situação de crise econômico-financeira da empresa devedora, de modo a que se mantenham as atividades produtivas, o emprego dos trabalhadores e os interesses dos credores. Dessa forma, se conserva a empresa, sua função social e o estímulo à atividade econômica. O plano de recuperação deve ser apresentado pela empresa devedora em juízo no prazo de 60 dias da publicação da decisão do processo de recuperação judicial. Há, também, a possibilidade de um plano de recuperação extrajudicial, que constitui uma tentativa do devedor de fazer um acordo de pagamento das obrigações aos credores sem intervenção judicial. A ordem de pagamentos deve ser acordada entre as partes.

Com relação ao processo de falência das empresas, a Lei definiu, no artigo 75, que o processo deve preservar e otimizar a utilização produtiva dos bens, ativos e recursos produtivos da empresa, inclusive os intangíveis. Nesse caso, o falido passou a ser desabilitado para exercer qualquer atividade empresarial a partir da decretação da falência e até a sentença final quanto às suas obrigações.

Conforme a nova lei, a ordem de pagamentos dos créditos da recuperação passou a ser a seguinte: (i) os créditos derivados da legislação do trabalho e os decorrentes de acidentes de trabalho; (ii) créditos com garantia real até o limite do valor do bem gravado; (iii) créditos tributários; (iv) créditos com privilégio especial, previstos no art. 964 da Lei ${ }^{\circ}$ 10.406/2002; (v) créditos com privilégio geral, previstos no art. 965 da Lei n 10.406/2002; (vi) créditos quirografários ${ }^{57}$; (vii) as multas contratuais e as penas pecuniárias por infração das leis penais ou administrativas; e, finalmente, (viii) créditos subordinados, créditos dos sócios e dos administradores sem vínculo empregatício.

A nova instituição deu maior segurança jurídica ao credor, com prioridade ao pagamento dos créditos segurados em caso de falência, e criou o mecanismo dos créditos extraconcursais. A nova lei também acelerou o processo e incentivou uma maior participação

\footnotetext{
${ }^{57}$ Crédito quirografário é aquele que tem como garantia apenas a promessa do devedor de que, no vencimento, irá honrar sua obrigação.
} 
das partes interessadas, reduzindo o risco dos bancos e do mercado de capitais e possibilitando juros e exigências de colateral menores. $\mathrm{O}$ impacto no risco do investimento se deu de duas formas: uma ex ante, pois possibilitou que o gestor decidisse quando decretar a falência ou requerer a recuperação econômica da empresa e outra ex post, pois houve redução dos custos de recuperação de garantias. Essa medida também afetou as expectativas dos agentes econômicos e deu maior segurança às empresas produtivas.

Araujo e Funchal (2009) analisaram os efeitos da nova Lei de Falência sobre os números de pedidos de recuperação e de falências e sobre o risco e o mercado de crédito. Os autores identificaram efeitos de redução nos números de falências e de recuperação e pedidos de concordatas após a introdução da nova lei. Dois fatores que explicam o efeito elevado e imediato da nova lei sobre o número de falências foram:

"o espírito da nova lei de salvar empresas economicamente viáveis foi rapidamente captado pelos juízes, [...] e segundo, a regulamentação dos acordos extrajudiciais permite que firmas se reestruturem, evitando suas quebras e reduzindo a necessidade de requerer a falência." (Araujo e Funchal, 2009, p.211)

A redução de $60 \%$ do número de pedidos de recuperação se deveu, segundo os autores, ao fato de a nova lei ter elevado o risco de decretação de falência em caso de rejeição do plano de recuperação, inibindo pedidos desnecessários de recuperação. Como no caso da Lei do Incontroverso discutida anteriormente, a nova lei reduziu os incentivos ao comportamento oportunista.

Por fim, vale observar que os autores verificaram efeitos positivos da nova lei sobre a oferta de crédito, com expansão para as pessoas jurídicas dos setores comercial, rural e de serviços. Araujo e Funchal (2009) indicaram que, apesar disso, não foi constatado qualquer efeito sobre as taxas de juros dos empréstimos, como era esperado do ponto de vista teórico.

O marco regulatório do saneamento - estabelecido pela Lei $n^{\circ} 11.445$ de 5 de janeiro de 2007 - criou as diretrizes nacionais para o saneamento básico no país e para a política do governo federal. O saneamento básico foi definido como o conjunto de serviços, infraestruturas e instalações operacionais de: abastecimento de água potável, esgotamento sanitário, limpeza urbana e manejo de resíduos sólidos e drenagem e manejo das águas pluviais urbanas. ${ }^{58}$ A lei não abordou diretamente a questão da titularidade dos serviços de

\footnotetext{
${ }^{58}$ De acordo com as diretrizes nacionais, os serviços de saneamento básico devem ser prestados seguindo os princípios de: (i) universalização do acesso; (ii) eficácia das ações e resultados; (iii) adequação à saúde pública e à proteção do meio ambiente; (iv) diferenças locais e regionais; (v) articulação com as políticas de desenvolvimento urbano e regional; (vi) eficiência e sustentabilidade econômica; (vii) utilização de tecnologias apropriadas; (viii) transparência
} 
saneamento básico, definido em Constituição como sendo do município; apenas determinou que o titular dos serviços públicos de saneamento básico podem delegar a organização, a regulação, a fiscalização e a prestação desses serviços.

A lei determinou a criação de entidade reguladora em cada titular com o objetivo de editar normas sobre as dimensões técnicas, econômicas e sociais de prestação dos serviços. Essas entidades devem ter autonomia administrativa, orçamentária e financeira para que possam atuar com independência decisória e transparência. A lei determinou que os serviços públicos de saneamento básico devem ter sustentabilidade econômico-financeira assegurada mediante remuneração pela cobrança dos serviços, o que pode ser feito na forma de tarifas, taxas ou tributos. Com relação aos aspectos técnicos, a lei previu que a prestação dos serviços deve atender a requisitos mínimos de qualidade, regularidade e continuidade.

O marco regulatório do saneamento criou condições mais favoráveis aos negócios e dirimiu intepretações controversas que inibiam os investimentos (titularidade). Contudo, mesmo considerando a recuperação do crédito para o setor, propiciada pelo aumento dos fundos no FGTS, o investimento no setor não se recuperou como o esperado. Isso se deveu ao fato de que grande parte dos municípios não tinha condições fiscais para contrair empréstimos. As empresas estaduais, as quais tinham a maior parte das concessões nas maiores unidades da Federação (São Paulo, Minas Gerais, Rio de Janeiro, por exemplo), também se encontravam em condições financeiras frágeis e com dificuldades de gestão, o que impossibilitou o avanço da universalização. Nesse sentido, o marco regulatório do saneamento pode ser visto como uma mudança institucional que não proveu as condições suficientes pra a mudança de comportamento dos agentes.

\subsection{Os anos 2010}

O novo marco regulatório do petróleo, instituído em 2010 por meio de um conjunto de três leis - Lei $n^{\circ} 12.351 / 2010$; Lei n 12.304/2010; e Lei ${ }^{\circ} 12.276 / 2010$ - estabeleceu o Regime de Partilha da Produção (RPP), criou o Fundo Social (FS) e a empresa Petróleo pré-Sal S.A. (PPSA), fixando diretrizes para a Petrobras nessa área. O sistema de partilha é usado por países que possuem grandes reservas e baixo risco de exploração. Nesse caso, a empresa ou consórcio contratado assume o risco das atividades de exploração, avaliação, desenvolvimento e produção de petróleo e gás natural e de outros hidrocarbonetos. Em caso de descoberta comercial, a empresa tem seus investimentos e custos ressarcidos

das ações; (ix) controle social; (x) segurança, qualidade e regularidade; (xi) integração das infraestruturas e serviços com a gestão eficiente dos recursos hídricos; e (xii) adoção de medidas de fomento à moderação do consumo de água. 
em proporção do custo do óleo. O excedente é calculado pela diferença entre a receita total e a soma de valor investido e dos custos de produção. Esse valor, convertido em óleo, é chamado de excedente em óleo e é repartido entre a empresa contratada e o governo, em porcentagens variáveis.

O Fundo Social (FS) é o fundo financeiro constituído pelos recursos gerados na partilha de produção com a finalidade de criar fonte de recursos para o desenvolvimento social e regional, por meio de programas e projetos nas áreas de combate à pobreza e de desenvolvimento da educação, cultura, esporte, saúde pública, ciência e tecnologia e meio ambiente. Os recursos do FS virão da comercialização da parcela do excedente em óleo, do bônus de assinatura e dos royalties que forem destinados à União.

A PPSA, criada pela Lei n ${ }^{\circ} 12.304$, de 2 de agosto de 2010, é uma empresa pública, sob a forma de sociedade anônima, vinculada ao Ministério de Minas e Energia. Seu objetivo é a gestão dos contratos de partilha de produção e de comercialização de petróleo, de gás natural e de outros hidrocarbonetos da União. A PPSA não é responsável pela execução das atividades de exploração, desenvolvimento, produção e comercialização de petróleo.

Por fim, a Lei n 12.276 , de 30 de junho de 2010, autorizou a União a ceder à Petrobras as atividades de pesquisa e lavra de petróleo, de gás natural e de outros hidrocarbonetos fluidos e a exploração de até 5 bilhões de barris de petróleo na área do pré-sal. A Lei $\mathrm{n}^{\circ}$ 12.351, de 22 de dezembro de 2010, definiu a Petrobras como o agente operador de todos os contratos sob o regime de partilha, garantindo-lhe uma participação mínima de 30\%, ou seja, havendo licitação, a empresa vencedora deverá, obrigatoriamente, constituir consórcio com a PPSA e a Petrobras, ficando sujeita às regras do edital e à proposta vencedora.

A descoberta do pré-sal influenciou fortemente a atividade de exploração e produção de petróleo, de gás natural e outros hidrocarbonetos, pois, diminuiu o risco das empresas exploradoras. Com essa nova configuração, foi necessária uma mudança institucional que revesse o antigo sistema de concessão no qual as empresas tinham um risco elevado e um retorno incerto. Com esse novo regime de partilha, o governo pretendeu obter maior controle da exploração do petróleo e fazer com que os recursos obtidos fossem revertidos para a sociedade. Como se trata de ampliação da capacidade instalada que ainda não entrou em produção, a mudança ainda não teve efeito sobre a geração de renda direta na economia. Contudo, os investimentos já apresentaram elevação em termos reais desde 2010 como ilustra o Gráfico 5.1. Essa mudança institucional deve afetar, no longo prazo, não só o setor de mineração, como também os investimentos em políticas públicas feitos com recursos específicos para o desenvolvimento social. 
O novo Código Florestal brasileiro, instituído pela Lei $\mathrm{n}^{\mathrm{o}}$ 12.651, de 25 de maio de 2012, estabeleceu normas gerais sobre a proteção da vegetação, a exploração florestal, o controle da origem dos produtos florestais e da prevenção de incêndios. Determinou as áreas de vegetação nativa que devem ser preservadas e quais regiões são legalmente autorizadas a receber os diferentes tipos de produção rural.

O novo código definiu as seguintes áreas de preservação: (i) Amazônia Legal: que abrange os Estados do Acre, Pará, Amazonas, Roraima, Rondônia, Amapá e Mato Grosso e as regiões situadas ao norte do paralelo $13^{\circ} \mathrm{S}$, dos Estados de Tocantins e Goiás, e ao oeste do meridiano de $44^{\circ} \mathrm{W}$, do Estado do Maranhão; (ii) Área de Preservação Permanente (APP): preservação de uma área com o objetivo de manter os recursos hídricos, a paisagem, a estabilidade geológica e a biodiversidade; ${ }^{59}$ (iii) Reserva Legal (RL): área de uma propriedade rural que deve ser preservada, com o objetivo de assegurar o uso econômico de modo sustentável dos recursos naturais da propriedade e promover a conservação da biodiversidade e a proteção de fauna e da flora nativa.

O novo código deve afetar diretamente o retorno do setor agropecuário, pois estabeleceu novos limites de áreas de preservação nas propriedades rurais do país. Ao dar maior liberalidade aos proprietários rurais, o código reduziu os custos ambientais que recaem sobre a produção agropecuária e o risco do não cumprimento das regras. Contudo, seus efeitos ambientais são incertos, o que gerou controvérsia com grupos de interesse ambientalistas.

A Lei $n^{0}$ 12.815, de 5 de junho de 2013, conhecida como Lei dos Portos, institui a nova legislação para regulação o setor no país. Ela dispôs sobre a exploração direta e indireta pela União de portos e instalações portuárias e sobre as atividades desempenhadas pelos operadores portuários. Instituiu o sistema de concessão e arrendamento a empresas que tenham capacidade para desempenhar as atividades e arcar com os riscos do negócio. De acordo com a anterior (Lei dos Portos de 1993), a licitação para a concessão do serviço portuário era feita pelo maior valor de outorga. Com a nova lei, o critério para a licitação dos contratos de concessão ou arrendamento passou a ser a maior eficiência com a menor tarifa,

\footnotetext{
${ }^{59}$ Para cada área de preservação, variando de acordo com a região e o bioma do local, o novo código estabeleceu o tamanho da área a ser preservada. Em APP, o código estabeleceu que deve ser mantida uma área mínima de floresta de: (i) curso d'água, conforme largura do rio; (ii) nascentes, em que a mata preservada deve ter raio de 50 metros de largura no mínimo; (iii) manguezais, que devem ser totalmente preservados; (iv) topos de morros e montanhas, em que se deve conservar todas as áreas com altura mínima de 100 metros; (v) encostas, todas as áreas com declividade superior a 45 graus devem ser preservadas; e (vi) nos tabuleiros ou chapadas, em que se deve manter as bordas até a ruptura do relevo. Nas áreas de Reserva Legal, o novo código determinou a ampliação dos tamanhos das reservas de acordo com a localização: (i) $80 \%$ em áreas de florestas da Amazônia Legal; (ii) $35 \%$ no cerrado; (iii) $20 \%$ em campos gerais; e (iv) $20 \%$ em todos os biomas das demais regiões do país.
} 
ou seja, maior movimentação possível de carga pelo menor preço por tonelada. Além disso, as licitações poderão ser realizadas na modalidade leilão.

A nova lei dos portos também criou o Programa Nacional de Dragagem Portuária e Hidroviária II, o qual passou a abranger as seguintes atividades: (i) obras e serviços de engenharia de dragagem para manutenção ou ampliação de áreas portuárias e de hidrovias; (ii) serviço de sinalização e balizamento; (iii) monitoramento ambiental; e (iv) gerenciamento da execução dos serviços e obras.

A nova instituição deve afetar em especial os serviços de transportes e logística, com efeitos secundários em praticamente todos os setores da economia. A lei deve afetar a economia na medida em que fomenta a ampliação dos investimentos privados e a modernização dos terminais, de forma a baixar os custos de logística e melhorar as condições de competitividade da economia brasileira.

\subsection{Síntese do período}

As seções 5.1 a 5.3 abrangeram uma vasta quantidade de instituições implantadas a partir dos anos 1990. O Quadro 5.1 traz uma síntese das principais mudanças na ordem legal e nas regras de mercado, considerando os setores que foram mais afetados. Também são sugeridos os mecanismos pelos quais essas mudanças afetaram o investimento: por meio da oferta de crédito (redução do risco dos credores e das despesas de recuperação de garantias) ou por meio do aumento do retorno do capital (redução da ineficiência associada aos custos de transação). A maioria das novas instituições afetou o investimento por meio de sua influência no retorno das empresas. Apenas cinco mudanças institucionais podem ser vistas como alterações que afetaram o crédito por darem maior segurança jurídica aos contratos e investidores. Todos os setores da economia brasileira foram afetados por alguma mudança institucional no período, o que contribui para entender a grande alteração nos valores e na composição setorial dos investimentos e do crédito. No Capítulo 7, será feita uma avalição do comportamento do investimento em cada setor de atividade econômica do país, o qual complementa as ideias discutidas neste capítulo. 


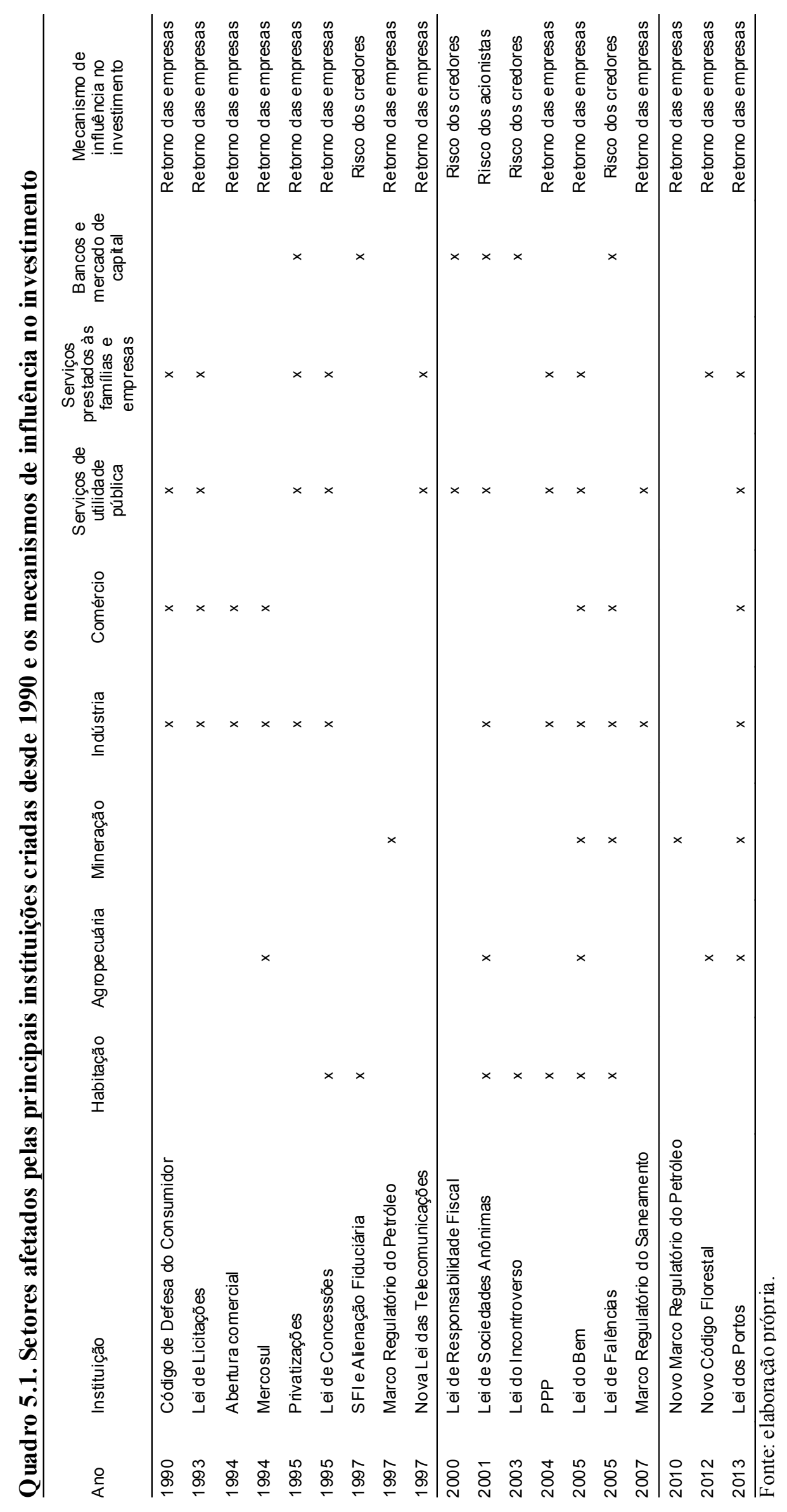




\section{Capítulo 6}

\section{A influência do crédito no investimento agregado}

Os achados empíricos do painel internacional desenvolvido no Capítulo 3 corroboraram a relação positiva entre investimento e crédito para um conjunto de países e as outras proposições teóricas importantes analisadas nos Capítulos 1 e 2. A avaliação histórica do Brasil feita nos últimos dois capítulos indicou transformações institucionais que influenciaram o risco de crédito e o retorno das empresas, com efeitos sobre o comportamento da oferta de fundos para o financiamento do investimento, da acumulação de capital e do crescimento econômico. Neste capítulo, essas relações serão investigadas para o caso brasileiro por meio de uma análise econométrica de séries de tempo entre 1953 e 2013, período que abrange várias fases do desenvolvimento econômico do país.

De acordo com a exposição histórica feita nos Capítulos 4 e 5, houve uma mudança institucional importante na década de 1960 que reestruturou o financiamento ao investimento no Brasil. Outro momento importante foi o final dos anos 1970, quando a política econômica teve que se ajustar às condições impostas pelos choques do petróleo e pela elevação das taxas de juros internacionais. Como discutido, isso afetou negativamente o crédito e o investimento no país. As reformas institucionais dos anos 1990 e 2000, por sua vez, tiveram por objetivo recuperar o crédito e o investimento no Brasil, variáveis que, de fato, cresceram a partir de 2003. Essas fases podem ser observadas no Gráfico 6.1 e 6.2 que mostram, respectivamente, a evolução do investimento e do crédito do BNDES no Brasil.

Nota-se que o investimento seguiu uma tendência crescente ao longo da história. Até finais dos anos 1960, contudo, o ritmo de expansão foi menor que o observado no período posterior às reformas financeiras de 1965-1967. Esse ritmo manteve-se mais intenso até o ano de 1980, momento a partir do qual começou a cair. Entre 1980 e 2003, o investimento oscilou no patamar de R $\$ 400$ bilhões por ano. A partir desse último ano, houve uma clara retomada do seu ritmo de expansão para um patamar próximo ao que havia antes da década de 1980. Em 2013, o investimento atingiu mais de R\$ 800 bilhões em reais de 2011, o dobro da média das duas décadas anteriores.

Com relação aos desembolsos do BNDES, também houve uma tendência de aceleração após as reformas de meados dos anos 1960, com queda dos financiamentos a partir da década de 1980. A retomada do crédito deu-se em duas fases: uma ainda na década de 1990 e outra, com crescimento mais forte, a partir de 2003. Houve apenas uma pequena queda 
em 2011, mas com recuperação no ano seguinte. Em 2013, os desembolsos do BNDES chagaram perto dos R $\$ 180$ bilhões (em reais de 2011), três vezes o patamar de desembolsos registrado no final da década de 1990.

Gráfico 6.1. Evolução do investimento no Brasil, R\$ de 2011, 1953 a 2013

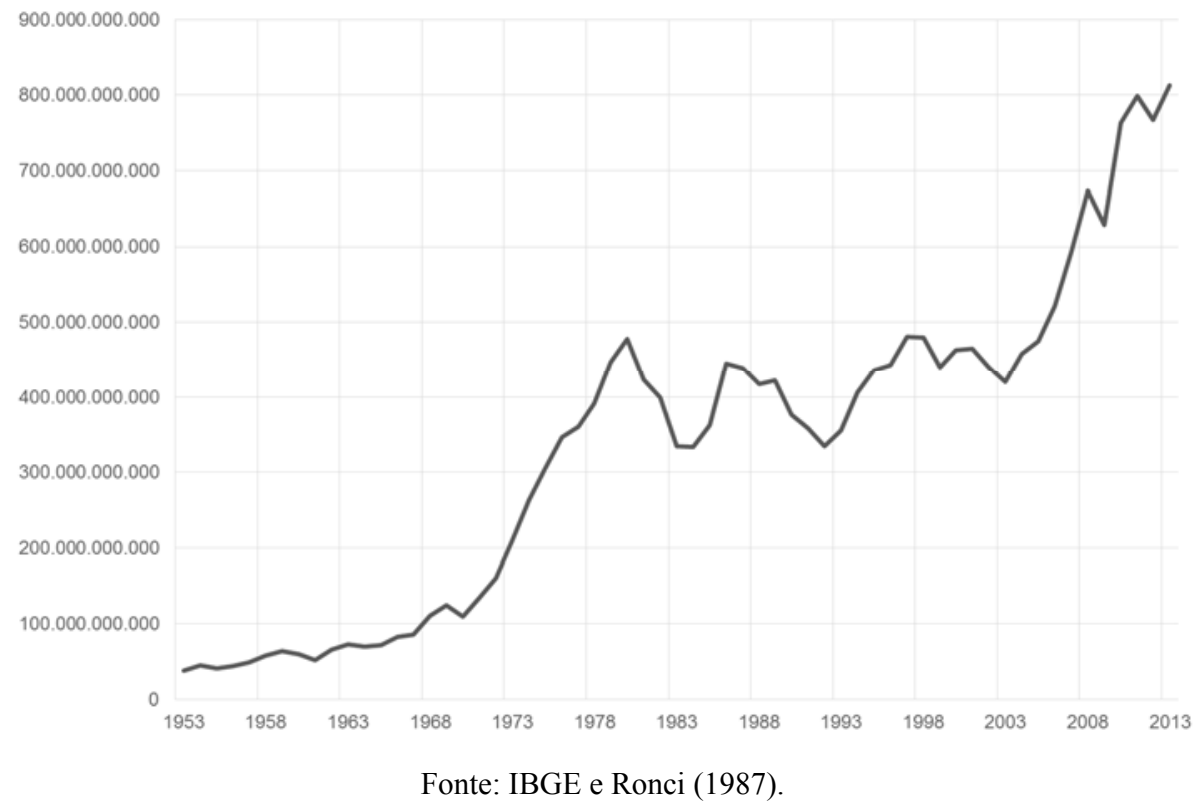

Gráfico 6.2. Evolução dos desembolsos do BNDES no Brasil, R\$ de 2011, 1953 a 2013

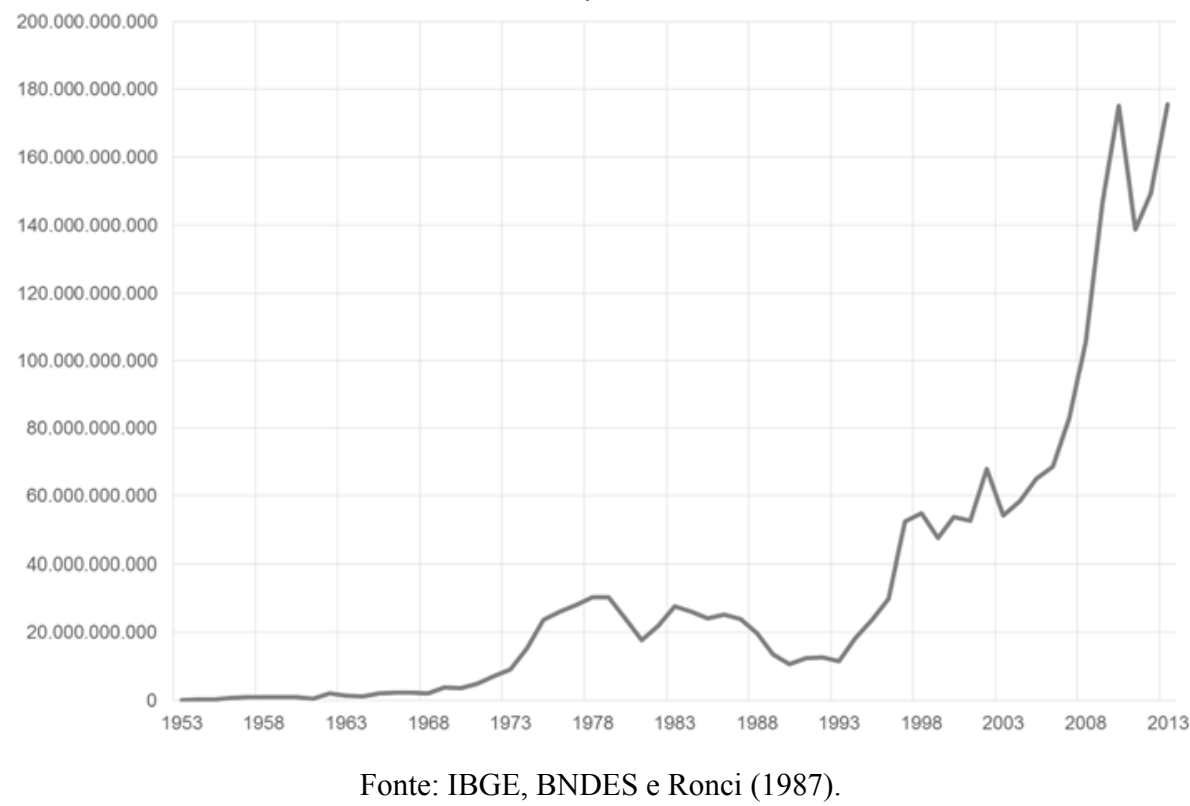

A seção 6.1 deste capítulo faz uma discussão sobre os principais trabalhos empíricos que analisaram a relação entre crédito e investimento no Brasil. A seção seguinte analisa a relação entre investimento, crédito, retorno esperado do capital e preço relativo do capital para o Brasil com base na metodologia de cointegração, considerando dados do período de 
1953 a 2013. Na seção, foi levada em consideração a possibilidade de ocorrência de quebras estruturais na relação de cointegração, algo que ocorre com maior frequência em séries de tempo longas. A seção final aplica metodologia de decomposição dos efeitos das variáveis determinantes do investimento sobre a acumulação de capital e o crescimento econômico ao caso brasileiro.

\subsection{Estudos sobre o Brasil}

A tese de doutoramento de Ronci (1987) constitui, possivelmente, a primeira contribuição econométrica para a análise empírica dos determinantes do investimento no Brasil. Ele estimou uma função investimento privado para o Brasil no período entre 1953 e 1982. Sua especificação foi baseada no trabalho de Blejer e Khan (1984) que definiram o investimento privado bruto como uma função do nível desejado de investimento e do investimento passado. O investimento desejado, por sua vez, depende da evolução do PIB $^{60}$, do comportamento dos custos de fatores (capital e trabalho), do estoque de capital e da participação dos gastos públicos na formação bruta de capital fixo.

Ronci (1987) estimou um modelo ADL (Autoregressive Distributed Lags) com variáveis contemporâneas e defasadas ${ }^{61}$, o que deu uma configuração dinâmica ao modelo. A estimação por MQO (Mínimos Quadrados Ordinários) partiu do modelo geral sobre o qual foram aplicadas restrições aos parâmetros e foram testados seus níveis de significância. Como algumas variáveis não foram estatisticamente significativas, o autor optou por estimar um modelo sem as variáveis de política - participação dos gastos do governo no PIB e o estoque de capital do governo - e foi acrescentado uma variável dummy de tempo com valor 1 entre os anos 1974 a 1978, período da administração do presidente Ernesto Geisel, e 0 nos demais períodos.

$\mathrm{O}$ autor concluiu que havia relações positivas entre o investimento privado, de um lado, e de outro (i) o PIB corrente e (ii) a razão entre o custo de capital e o preço dos insumos intermediários, tanto no período corrente como passado. Ou seja, o nível de atividade afetou positivamente o investimento privado brasileiro e quanto maior o custo do capital em relação ao custo dos bens intermediários, maior foi o investimento. Obtiveram-se, também, relações negativas entre o investimento privado, de um lado, e as seguintes variáveis, de

\footnotetext{
${ }^{60}$ Como discutido no Capítulo 3, essa especificação teórica em que o investimento desejado depende do PIB parte da premissa de acelerador de investimento flexível na qual o estoque de capital desejado é proporcional ao nível esperado de produto.

${ }^{61} \mathrm{O}$ autor empregou uma defasagem para todas as variáveis e duas defasagens, para o PIB e o estoque de capital privado.
} 
outro: (iii) o PIB defasado, (iv) a razão custo de capital e o salário nominal, no período corrente e no passado, (v) a taxa de juros, no período corrente e no passado, e (vi) o estoque de capital privado defasado. As bases de dados empregadas foram trabalhadas de maneira bastante rigorosa pelo autor e os resultados são bastante intuitivos, com exceção da relação positiva entre investimento privado e a razão entre custo do capital e custo de bens intermediários. $^{62}$

Rocha e Teixeira (1996) avaliaram o impacto do investimento público sobre o investimento privado no Brasil no período 1965 a 1990. Partiram de uma função em que o investimento privado é determinado pelo PIB, pela taxa de juros (proxy para o custo de utilização do capital) e pelo investimento público. A análise empírica foi baseada num teste de cointegração segundo a metodologia de Engle-Granger e um modelo de correção de erros. O modelo de correção de erros que apresentou o melhor ajustamento apontou para uma relação negativa, mas não significativa, entre investimento público e privado. O PIB afetava de forma positiva e significativa o investimento, e a taxa de juros, de forma negativa, mas não significativa. Apesar do número muito pequeno de observações -25 ao total $-\mathrm{o}$ artigo avança em alguns pontos importantes no que diz respeito à econometria. São feitos testes DF (Dickey-Fuller) e ADF (Dickey-Fuller Aumentado) para avaliar a estacionariedade das séries e é aplicado um teste de cointegração de Engle-Granger ${ }^{63}$.

Numa linha de trabalho muito próxima, Cruz e Teixeira (1999) analisaram o impacto do investimento público sobre o investimento privado no Brasil no período de 1947 a 1990. Seguindo Rocha e Teixeira (1996), os autores partem da premissa de que o investimento privado é função do produto agregado, da taxa de juros e do investimento público. A análise de estacionariedade, feita com base no teste $\mathrm{ADF}$, indicou que todas as séries consideradas eram integradas de primeira ordem. Os autores também estimaram um modelo

\footnotetext{
${ }^{62}$ A econometria empregada pelo autor apresenta limitações. O primeiro problema é o fato de o autor não ter desenvolvido nenhum tipo de análise com relação à estacionariedade das séries, algo muito recente na época. Depois, a premissa de que o PIB é exógeno parece forte demais, tendo em vista a importância do próprio investimento na determinação do PIB - um consenso teórico e empírico. Tomando por referência uma formulação genérica do modelo $\mathrm{ADL}-y_{t}=m+\alpha_{1} y_{t-1}+\beta_{0} x_{t}+\beta_{1} x_{t-1}+\varepsilon_{t}$, em que $y_{t}$ e $x_{t}$ são variáveis estacionárias e $\varepsilon_{t}$ é um ruído branco -, sabe-se que se $x_{t}$ for uma variável exógena e não correlacionada com $\varepsilon$, então a estimação do modelo por MQO é consistente. Esse não parece ser o caso do PIB, da remuneração de fatores ou do investimento público, que dificilmente seriam exógenas e estacionárias.

${ }^{63}$ O procedimento de Engle e Granger (1987) consiste m estimar por MQO a relação entre as variáveis integradas de mesma ordem e, depois, aplicar um teste ADF sobre os resíduos. Se as séries forem integradas de ordem um e se os resíduos da regressão dessas séries forem estacionários, pode-se dizer que as variáveis são cointegradas de ordem um. Essa metodologia sofre três críticas na literatura econométrica: (i) a metodologia requer que as variáveis sejam classificadas a priori em endógenas ou exógenas; (ii) o teste é feito em duas etapas e há ausência de dinâmica na primeira etapa, o que pode reduzir a potência do teste; e (iii) o procedimento está limitado a estimar apenas um vetor de cointegração, excluindo a possibilidade de haver dois ou mais vetores de cointegração no caso de relações entre um número maior de variáveis.
} 
ADL - aos moldes do desenvolvido por Ronci (1987) -, assumindo as premissas de que: (i) o PIB e o investimento público são variáveis fracamente exógenas e (ii) existe apenas um vetor de cointegração entre as variáveis. As relações também foram estimadas utilizando o modelo de correção de erros.

Os autores chegaram à conclusão de que apenas as primeiras defasagens das variáveis no modelo $\mathrm{ADL}$ eram significativas. $\mathrm{O}$ coeficiente associado à taxa de juros foi estatisticamente não significativo e o relacionado ao PIB apresentou sinal positivo e significativo. Aos moldes da relação estimada por Rocha e Teixeira (1996), Cruz e Teixeira (1999) encontraram uma relação negativa entre investimento público e investimento privado. Contudo, as estimativas feitas com base no modelo de correção de erros apontaram para a existência de uma relação positiva de longo prazo entre o investimento público e o investimento privado. A identificação de uma relação sistemática de longo prazo entre as variáveis e o uso de banco de dados com um número maior de observações (42) constituem avanços na análise empírica dos determinantes do investimento, muito embora ainda prevaleçam as críticas dirigidas à suposição do PIB como variável fracamente exógena.

Ribeiro e Teixeira (2001) ampliaram a discussão e a gama de modelos econométricos em relação à literatura anterior: além de aplicar as metodologias de ADL e de EngleGranger, os autores utilizaram o procedimento de Johansen na análise de cointegração. $\mathrm{O}$ banco de dados compreende informações entre 1956 e 1996, partindo de uma formulação geral em que há um conjunto grande de fatores determinantes do investimento: o PIB, a taxa real de juros, o investimento público, o crédito disponível para o investimento (aproximado pelo valor de desembolsos do BNDES), o peso da dívida externa, a taxa de câmbio (como proxy do custo de bens de capital) e a estabilidade macroeconômica (aproximada pela taxa anual de inflação).

Antes de estimar as relações entre as variáveis, os autores aplicaram testes de estacionariedade $\mathrm{ADF}$ e de Perron às séries, indicando que inflação e juros são estacionários e as demais séries são integradas de primeira ordem. No modelo $\mathrm{ADL}^{64}$ estimado pelos autores, o investimento privado foi considerado como uma função de seu valor defasado e do nível e das defasadas das seguintes variáveis: PIB, dívida externa, taxa de câmbio e crédito. Também foi estimado um modelo ADL em que o investimento privado foi considerado como uma função do investimento público. Na sequência, os autores fizeram análises de cointegração Engle-Granger e Johansen para os dois conjuntos de relações analisadas. As análises

\footnotetext{
${ }^{64} \mathrm{O}$ modelo ADL utilizado pelos autores partiu da estimação de uma equação geral e, a partir da aplicação de testes de restrições, reduziu o número de variáveis, eliminando as defasagens e as variáveis estatisticamente não significativas.
} 
consideraram apenas as variáveis integradas de ordem um e que apareceram significativas na determinação do investimento privado pelos modelos ADL: PIB, taxa de câmbio e crédito, para o primeiro modelo, e investimento público, para o segundo.

Seguindo a metodologia de Engle-Granger, os autores chegaram à conclusão de que as variáveis eram cointegradas de ordem um, visto que os resíduos das duas equações estimadas resultaram estacionários. Os autores apontaram para a existência de relações de longo prazo positivas entre investimento privado, PIB e crédito, e uma relação negativa entre investimento privado e a taxa de câmbio. $O$ teste de cointegração conforme a metodologia de Johansen chegou a resultados semelhantes. Foi estimado um VAR de ordem 3 para o vetor formado por investimento privado, PIB, taxa de câmbio e crédito, e outro VAR, de ordem 1, para a relação entre investimento privado e público. Obteve-se apenas um vetor de cointegração em ambos os modelos e os coeficientes de longo prazo estimados foram similares aos obtidos no procedimento de Engle-Granger.

As conclusões do artigo de Ribeiro e Teixeira (2001) obviamente se beneficiaram das vantagens da metodologia de Johansen (1995): com ela é possível estimar mais de um vetor de cointegração, no caso de haver três ou mais variáveis. A metodologia de Johansen prescinde da classificação das variáveis entre endógenas ou exógenas, pois ela parte da estimação de um modelo autorregressivo vetorial (VAR), que é um modelo dinâmico.

Acosta e Loza (2005) analisam os determinantes de curto e longo prazo dos investimentos na Argentina entre 1970 e 2000 aos moldes do estudo de Ribeiro e Teixeira (2001). As estimativas estão bem próximas aos resultados discutidos anteriormente: de forma geral, o ritmo de acumulação de capital do setor privado argentino foi determinado, no curto prazo, por fatores transitórios (taxa de câmbio, inflação e liberalização do comércio) assim, como por choques no nível de demanda agregada. No longo prazo, a taxa de crescimento da economia, o nível da dívida externa e as restrições de crédito doméstico influenciaram a trajetória do investimento privado no país.

Mais recentemente Luporini e Alves (2010) fizeram uma análise empírica para avaliar os determinantes do investimento privado no Brasil. Sua análise compreendeu o período de 1970 a 2005 e também partiu de um modelo autorregressivo de defasagens distribuídas (ADL) para estimar os efeitos de variáveis tradicionalmente consideradas importantes para o investimento privado. Os autores empregaram um número maior de testes de raiz unitária: Dickey-Fuller GLS, Phillips-Perron e KPSS, além do ADF.

As séries de juros reais, investimento público e taxa real de câmbio resultaram estacionárias; as demais eram integradas de ordem 1. Os resultados obtidos indicaram que o 
PIB estava positivamente relacionado ao investimento privado no Brasil no período estudado. O investimento público apresentou relação positiva, mas não significativa, com o investimento privado, assim como a taxa de juros. Por fim, o crédito apresentou uma relação positiva e significativa com o investimento privado.

\subsection{Oferta de crédito e investimento agregado no Brasil}

\subsubsection{Base de dados e metodologia}

De acordo com os trabalhos empíricos descritos na seção anterior, as principais variáveis que afetam o investimento brasileiro foram: o PIB, a taxa real de câmbio (como proxy do custo de bens de capital), a oferta de crédito, a taxa real de juros e a inflação (como indicador de instabilidade macroeconômica). Nenhum trabalho, contudo, incluiu alguma variável que indicasse diretamente a taxa de retorno do capital como algo que interfere na decisão de investimento, conforme discutido na fundamentação teórica e analisado empiricamente para um conjunto amplo de países nos modelos econométricos do Capítulo 3. Apenas o trabalho de Ronci (1987) considerou o preço do capital como variável determinante do investimento, mas como indicador do preço relativo de fatores (uma premissa microeconômica de alocação), e não como preço dos ativos relativamente ao custo de reposição ( $Q$ de Tobin).

Aos moldes do que desenvolvido no Capítulo 3, a análise deste capítulo não incluiu entre as variáveis explicativas do investimento o PIB e sua taxa de crescimento. Em vez disso, considerou como variável explicativa dos investimentos a estimativa de retorno esperado do capital (estimado a partir da produtividade marginal do capital e dos níveis de PIB e estoque de capital), a mesma variável empregada na análise de sensibilidade feita no Capítulo 3 e cuja justifica teórica está presente na maior parte das teorias sobre o investimento. Também foi considerada uma medida direta do preço dos ativos, como uma alternativa à taxa de câmbio, ao preço relativo de fatores e inflação. De qualquer forma, a taxa de câmbio foi mantida como variável de controle, pois pode capturar o diferencial de retorno dos títulos públicos brasileiros em relação aos títulos norte-americanos, como proposto por Le (2004). Devido à indisponibilidade de dados sobre a taxa de juros de longo prazo ${ }^{65}$ para todo o período analisado, essa variável não constou da análise feita neste capítulo. Dessa

\footnotetext{
${ }^{65}$ A taxa de juros de curto prazo, uma variável empregada pelos autores discutidos na seção anterior e para a qual há informações, não foi considerada na econometria desenvolvida neste capítulo. Isso porque essa variável não reflete necessariamente o custo do capital de terceiros (BNDES) e, portanto, as decisões de investimentos de longo prazo.
} 
forma, as especificações econométricas guardaram a maior proximidade possível das relações teóricas e empíricas discutidas na Parte 1 da tese.

A base de dados veio de diversas fontes a depender da série ou do período. Os dados são anuais e referem-se ao período 1953 a 2013, totalizando 61 observações. A seguir são apresentadas as descrições das séries:

- Investimento: corresponde a formação bruta de capital fixo das Contas Nacionais do IBGE, em milhões de reais de 2011, considerando o deflator implícito dos investimentos do IBGE. Esta última série está disponível somente para o período pós 1970; para os períodos anteriores, foi utilizada a estimativa de deflator do investimento feita por Ronci (1987).

- Crédito: como indicador da disponibilidade de crédito de longo prazo foi utilizado o montante de empréstimos do Banco Nacional de Desenvolvimento Econômico e Social (BNDES). A série foi encadeada a partir de duas bases fornecidas pelo próprio BNDES. Os valores estão a preços de 2011, considerando a variação do deflator implícito de bens de capital.

- Retorno esperado do capital: a estimativa dessa variável foi definida como a relação entre a parcela esperada do capital na distribuição funcional da renda e o estoque de capital. Essa série foi construída com base na mesma metodologia empregada no Anexo 3.1 do Capítulo 3. Essa metodologia usou informações de PIB, estoque de capital e oferta de trabalho para estimar a elasticidade do PIB em relação ao capital. Como são necessárias informações para um período maior de tempo, foi realizada uma nova estimativa para um painel de 100 economias com dados entre $1950 \mathrm{e}$ 2013. Essa base de dados e as estimativas realizadas sobre ela são apresentadas no Anexo 6.1.

- Taxa real de câmbio: cotação média anual da taxa de venda do Banco Central do Brasil em R\$ por US\$. A taxa foi deflacionada pelo deflator implícito do PIB brasileiro - indicador da inflação no Brasil - e corrigida pelo deflator implícito do PIB norte-americano, indicador da inflação em US\$. Os dados do deflator norteamericano foram obtidos no World Development Indicators (WDI on line).

- Preço relativo do capital: a medida de preço relativo do capital foi obtida pela divisão do índice de deflator implícito do estoque de capital pelo índice de deflator implícito do PIB. Ambas as séries estão na base 1980=100 e foram obtidas no IBGE. 
No caso do deflator implícito do capital, a série foi encadeada com os dados de Ronci (1987) para os anos de 1953 a 1969.

Como o investimento e o crédito apresentaram comportamento heterocedástico, optou-se por trabalhar com as séries transformadas por logaritmo natural. A Tabela 6.1 traz as estatísticas descritivas das séries utilizadas.

Tabela 6.1. Estatísticas descritivas das variáveis, 1953 a 2013

\begin{tabular}{lrrrr}
\hline Variáveis & Média & $\begin{array}{r}\text { Desvio } \\
\text { padrão }\end{array}$ & Mínimo & Máximo \\
\hline Investimento $(\mathrm{In})$ & 26,2107 & 0,9242 & 24,3716 & 27,4236 \\
Crédito $(\mathrm{In})$ & 23,2279 & 1,7655 & 19,0863 & 25,8919 \\
Retorno esperado do capital & 0,3142 & 0,0528 & 0,2366 & 0,4004 \\
Taxa real de câmbio $(\mathrm{In})$ & 1,2352 & 0,2824 & 0,5158 & 1,6753 \\
Preço relativo do capital & 1,1788 & 0,1328 & 0,9715 & 1,5790 \\
\hline
\end{tabular}

Fonte: IBGE, Banco Central, BNDES, Ronci (1987). Nota: total de 61 observações.

Foram aplicados quatro testes de raiz unitária: (i) Dickey e Pantula (DP), (ii) Dickey e Fuller Aumentado (ADF), (iii) KPSS e (iv) Generalised Least Squares Dickey-Fuller (DFGLS). A hipótese básica na qual se baseiam os testes é a condição de estacionariedade do processo estocástico. Dickey e Pantula (1987) é o único que verifica a presença de múltiplas raízes unitárias. Após os testes de raiz unitária, foram empreendidos os procedimentos de Johansen para avaliar a cointegração entre diferentes conjuntos de variáveis. No Anexo 6.2, há uma breve descrição dos testes de raiz unitária e cointegração.

\subsubsection{Testes de raiz unitária}

Os testes de raiz unitária foram aplicados ao conjunto de seis séries macroeconômicas necessárias para o desenvolvimento da análise de cointegração. Os resultados do teste de Dickey e Pantula são apresentados nas Tabelas 6.2 e 6.3. Na primeira tabela, são apresentados os resultados do teste de existência de duas raízes unitárias contra uma raiz unitária. Para todas as séries, a análise resultou em testes com o modelo sem termos deterministas (modelo 1). ${ }^{66} \mathrm{O}$ número de defasagens foi determinado pela significância da maior defasagem, que resultou em nenhuma defasagem para todas as séries. Ao comparar as estatísticas $t$ dos coeficientes estimados de cada série com os valores críticos correspondentes, rejeitou-se, ao nível de significância de 5\%, a hipótese nula de duas raízes unitárias.

Na Tabela 6.3 são apresentados os resultados do teste de existência de uma raiz unitária contra a hipótese alternativa de estacionariedade. A maioria das séries não teve termos

\footnotetext{
${ }^{66}$ Os testes de termos deterministas seguem o procedimento proposto em Dickey e Fuller (1981).
} 
deterministas, com exceção do preço relativo do capital, que apresentou constante. O número de defasagens também foi determinado pela análise da significância da maior defasagem, que resultou em nenhuma defasagem para todas as séries.

Tabela 6.2. Resultados do teste de Dickey e Pantula - Primeira Etapa

\begin{tabular}{lccccc}
\hline Variáveis & $\begin{array}{c}\text { Termos } \\
\text { determinista }\end{array}$ & $\begin{array}{c}\text { Número de } \\
\text { defasagens }\end{array}$ & $\begin{array}{r}\text { Estatística } \\
\text { do teste }\end{array}$ & VC à 5\% & Conclusão \\
\hline Investimento $(\mathrm{In})$ & - & 0 & $-5,26$ & $-1,946$ & $1 \mathrm{RU}$ \\
Crédito $(\mathrm{In})$ & constante & 0 & $-3,25$ & $-2,909$ & $1 \mathrm{RU}$ \\
Retorno esperado do capital & - & 0 & $-4,95$ & $-1,946$ & $1 \mathrm{RU}$ \\
Taxa real de câmbio $(\mathrm{In})$ & - & 0 & $-6,96$ & $-1,946$ & $1 \mathrm{RU}$ \\
Preço relativo do capital & - & 0 & $-8,53$ & $-1,946$ & $1 \mathrm{RU}$ \\
\hline Fonte: Cálculos próprios. & & & & &
\end{tabular}

Tabela 6.3. Resultados do teste de Dickey e Pantula - Segunda Etapa
\begin{tabular}{lccccccr}
\hline Variáveis & $\begin{array}{c}\text { Termos } \\
\text { deterministas }\end{array}$ & $\begin{array}{r}\text { Número de } \\
\text { defasagens }\end{array}$ & $\begin{array}{r}\text { Estatística } \\
\text { do teste }-t_{1}\end{array}$ & $\begin{array}{r}\text { Estatística } \\
\text { do teste }-t_{2}\end{array}$ & VC à $5 \%$ & Conclusão \\
\hline Investimento $(\mathrm{In})$ & - & 0 & $-5,99$ & 2,43 & $-1,946$ & $1 \mathrm{RU}$ \\
Crédito $(\mathrm{In})$ & - & 0 & $-7,85$ & 2,60 & $-1,946$ & $1 \mathrm{RU}$ \\
Retorno esperado do capital & - & 0 & $-5,00$ & $-0,86$ & $-1,946$ & $1 \mathrm{RU}$ \\
Taxa real de câmbio $(\mathrm{In})$ & - & 0 & $-6,96$ & $-0,86$ & $-1,946$ & $1 \mathrm{RU}$ \\
Preço relativo do capital & constante & 0 & $-7,19$ & $-3,33$ & $-2,909$ & Estacionária
\end{tabular}

Fonte: Cálculos próprios.

Ao comparar as estatísticas $t_{1}$ e $t_{2}$ dos coeficientes estimados de cada série com os valores críticos correspondentes, concluiu-se que não é possível rejeitar, ao nível de significância de 5\%, a hipótese nula de uma raiz unitária para todas as séries analisadas, o que está em consistência com a etapa anterior. A exceção foi a série de preço relativo do capital, que aparece como estacionária.

Tabela 6.4. Resultados do teste ADF

\begin{tabular}{lcccrc}
\hline Variáveis & $\begin{array}{c}\text { Termos } \\
\text { deterministas }\end{array}$ & $\begin{array}{c}\text { Número de } \\
\text { defasagens }\end{array}$ & $\begin{array}{r}\text { Estatística } \\
\text { do teste }\end{array}$ & VC à 5\% & Conclusão \\
\hline Investimento $(\mathrm{In})$ & - & 0 & 3,62 & $-1,950$ & $1 \mathrm{RU}$ \\
Crédito $(\mathrm{In})$ & - & 0 & 2,80 & $-1,950$ & $1 \mathrm{RU}$ \\
Retorno esperado do capital & - & 1 & $-1,02$ & $-1,950$ & $1 \mathrm{RU}$ \\
Taxa real de câmbio $(\mathrm{In})$ & - & 0 & $-0,69$ & $-1,950$ & $1 \mathrm{RU}$ \\
Preço relativo do capital & constante & 0 & $-3,57$ & $-2,922$ & Estacionária \\
\hline
\end{tabular}

Fonte: Cálculos próprios.

A Tabela 6.4 traz os resultados do teste ADF. Assim como no teste anterior, os modelos especificados não têm termos deterministas, com exceção da série de preço relativo do capital. $\mathrm{O}$ número de defasagens também foi determinado pela significância da maior defasagem e os modelos foram especificados sem defasagens, com exceção do retorno esperado do capital. Ao comparar as estatísticas $t$ dos coeficientes estimados com os valores 
críticos correspondentes, concluiu-se que não é possível rejeitar, ao nível de significância de $5 \%$, a hipótese nula de uma raiz unitária para todas as séries analisadas. Novamente, o preço relativo do capital é uma exceção. Esse resultado confirma os resultados encontrados no teste de Dickey e Pantula.

A Tabela 6.5 traz os resultados do teste KPSS. O número de defasagens, segundo o critério de Newey-West, é de 2 para todos os testes, com constante e tendência e apenas com constante. No modelo com constante, a premissa de estacionariedade foi rejeitada ao nível de significância de 5\% para a maioria das variáveis. Apenas nos casos da taxa real de câmbio e do preço relativo do capital, a premissa de estacionariedade não foi rejeitada. No caso do modelo com constante e tendência, a premissa de estacionariedade não foi rejeitada ao nível de significância de 5\% apenas no caso do preço relativo do capital.

Tabela 6.5. Resultados do teste KPSS

\begin{tabular}{|c|c|c|c|c|c|c|}
\hline \multirow[b]{2}{*}{ Variáveis } & \multicolumn{3}{|c|}{ Modelo com constante* } & \multicolumn{3}{|c|}{ Modelo com constante e tendência** } \\
\hline & $\begin{array}{l}\text { Número de } \\
\text { defasagens }\end{array}$ & $\begin{array}{l}\text { Estatística } \\
\text { do teste }\end{array}$ & Conclusão*** & $\begin{array}{l}\text { Número de } \\
\text { defasagens }\end{array}$ & $\begin{array}{c}\text { Estatística } \\
\text { do teste }\end{array}$ & Conclusão*** \\
\hline Investimento (In) & 2 & 0,475 & rejeita $\mathrm{HO}$ & 2 & 2,070 & rejeita $\mathrm{HO}$ \\
\hline Crédito (In) & 2 & 0,326 & rejeita HO & 2 & 2,080 & rejeita HO \\
\hline Retorno esperado do capital & 2 & 0,260 & rejeita $\mathrm{HO}$ & 2 & 1,780 & rejeita $\mathrm{HO}$ \\
\hline Taxa real de câmbio (In) & 2 & 0,128 & não rejeita H0 & 2 & 0,803 & rejeita $\mathrm{HO}$ \\
\hline Preço relativo do capital & 2 & 0,101 & não rejeita H0 & 2 & 0,243 & não rejeita $\mathrm{H} 0$ \\
\hline
\end{tabular}

Fonte: Cálculos próprios. Notas: $\left({ }^{*}\right)$ valores críticos do teste: $10 \%: 0,119 ; 5 \%: 0,146 ; 2,5 \%: 0,176 ; 1 \%: 0,216 .\left(^{* *}\right)$ valores críticos do teste: $10 \%$ : 0,347; 5\%: 0,463; 2,5\%: 0,574; 1\%: 0,739. $(* * *)$ ao nível de significância de 5\%.

\section{Tabela 6.6. Resultados do teste DF-GLS}

\begin{tabular}{|c|c|c|c|c|c|c|}
\hline \multirow[b]{2}{*}{ Variáveis } & \multicolumn{3}{|c|}{ Modelo com constante* } & \multicolumn{3}{|c|}{ Modelo com constante e tendência** } \\
\hline & $\begin{array}{l}\text { Número de } \\
\text { defasagens }\end{array}$ & $\begin{array}{l}\text { Estatística } \\
\text { do teste }\end{array}$ & Conclusão*** & $\begin{array}{l}\text { Número de } \\
\text { defasagens }\end{array}$ & $\begin{array}{l}\text { Estatística do } \\
\text { teste }\end{array}$ & Conclusão*** \\
\hline Investimento (In) & 1 & 0,830 & $1 \mathrm{RU}$ & 1 & $-1,222$ & $1 \mathrm{RU}$ \\
\hline Crédito (In) & 1 & 1,355 & $1 \mathrm{RU}$ & 1 & $-1,301$ & $1 \mathrm{RU}$ \\
\hline Retorno esperado do capital & 1 & $-1,173$ & $1 \mathrm{RU}$ & 1 & $-1,967$ & $1 \mathrm{RU}$ \\
\hline Taxa real de câmbio (In) & 1 & $-2,052$ & $1 \mathrm{RU}$ & 1 & $-2,426$ & $1 \mathrm{RU}$ \\
\hline Preço relativo do capital & 1 & $-2,232$ & Estacionária & 1 & $-2,961$ & $1 \mathrm{RU}$ \\
\hline
\end{tabular}

Fonte: Cálculos próprios. $\left(^{*}\right)$ valores críticos do teste: $10 \%:-1,924 ; 5 \%:-2,226 ; 1 \%:-2,616$. (**) valores críticos do teste: 10\%: $-2,857 ; 5 \%:-3,155 ; 1 \%:-3,728$. (***) ao nível de significância de $5 \%$.

O teste DF-GLS é mais potente que o ADF na presença de termos deterministas. Como a série de preço relativo apresentou constante e as estatísticas dos testes estavam muito próximas dos valores críticos ao nível de significância de 5\%, optou-se pela aplicação desse teste alternativo para confirmar os resultados. O número de defasagens foi determinado pelo critério de informação de Schwarz, com apenas uma defasagem para os modelos com constante e com constante e tendência. A Tabela 6.6 traz os resultados. No modelo 
com constante, a hipótese nula de uma raiz unitária não foi rejeitada ao nível de significância de 5\%, com exceção do preço relativo do capital. Neste caso, a hipótese nula não foi rejeitada ao nível de significância de $10 \%$. No caso do modelo com constante e tendência, não se rejeitou a hipótese de uma raiz unitária ao nível de 5\%, sem exceção.

Tendo por base o conjunto dos resultados dos testes de raiz unitária, pode-se concluir que as séries são integradas de ordem 1. As únicas dúvidas dizem respeito à série de preço relativo do capital. Contudo, vale lembrar que essa série apresenta uma constante de acordo com os testes de Dickey e Fuller (1981). Na presença de termos determinísticos, o teste DF-GLS é mais potente e, para o modelo com constante, não refutou a hipótese de uma raiz unitária a 10\% e, para o modelo com constante e tendência, a 5\%. Assim, optou-se por empreender-se a análise de cointegração assumindo que todas as séries são integradas de ordem 1.

\subsubsection{Testes de cointegração}

A análise de cointegração partiu da especificação teórica desenvolvida no Capítulo 2, o qual mostrou uma relação positiva entre investimento, crédito e retorno esperado do capital. Essa relação foi testada para um conjunto amplo de países no Capítulo 3, com resultados que corroboraram as relações teóricas estabelecidas. No presente capítulo também foram desenvolvidos outros testes de cointegração que consideram a taxa de câmbio e preço relativo do capital. Ao total, são analisados 3 conjuntos de relações:

(i) Investimento, retorno esperado do capital e oferta de crédito;

(ii) Investimento, retorno esperado do capital, oferta de crédito e taxa real de câmbio; e

(iii) Investimento, retorno esperado do capital, oferta de crédito e preço relativo do capital.

A análise gráfica das variáveis indicou que o modelo mais simples (sem termos deterministas) foi o mais adequado, visto que as primeiras diferenças das séries estavam entrelaçadas e tinham tendência comum. Primeiramente, foi estimado um VAR para cada modelo e foi testada a ordem de defasagens. A determinação do número de defasagem do modelo VAR foi feita com base nos critérios de informação, cujas estatísticas são apresentadas na Tabela A.6.3.1 do Anexo 6.3. Foram utilizados os critérios de Akaike (AIC), HannanQuinn (HQIC) e Schwarz (SC). Segundo esses critérios, foi indicada apenas uma defasagem nos três casos. Para os modelos (i) e (iii), o critério de AIC indicou duas defasagens, 
mas optou-se por trabalhar com apenas uma defasagem, por ter sido o indicado pelos outros dois critérios.

$\mathrm{Na}$ etapa seguinte, foi feito o teste de cointegração e estimado um VEC (sem defasagens). A Tabela A.6.3.2 do anexo traz os testes do traço e do máximo autovalor para todos os modelos analisados. Os testes determinaram a existência de apenas um vetor de cointegração. Os testes de autocorrelação e de normalidade dos resíduos dos modelos estimados são apresentados nas Tabelas A.6.3.3 e A.6.3.4 do referido anexo. O multiplicador de Lagrange (LM) indicou que, no geral, os resíduos não apresentaram problemas de autocorrelação para as ordens mais baixas. Os modelos (i) e (iii) apresentaram problemas nas ordens 5 e 6, respectivamente. Em geral, os problemas de resíduos correlacionados estão associados à especificação do modelo (termos deterministas e número de defasagens). Contudo, a inclusão de mais defasagens, ou de termos deterministas, gerou problemas de normalidade.

Os resultados do teste de Jarque-Bera, empregado para analisar a normalidade dos resíduos, é apresentado na Tabela A.6.3.4. Nesse teste, foram analisados os coeficientes de assimetria e curtose de todas as séries, individual e conjuntamente, para cada especificação. Observou-se que não há problemas de normalidade dos resíduos para os modelos (i) e (ii). Contudo, no terceiro caso, houve problema de curtose associada a séries de preço relativo do capital, o que indica que os resíduos estão muito concentrados em valores próximos de zero.

Em geral, os problemas de não normalidade dos resíduos estão associados a presença de 'outliers' ou quebras estruturais nas séries. Foi testada a inclusão de dummy para corrigir os outliers para os anos de 1988, 1989 e 1990. Contudo, a inclusão dessas variáveis gerou problemas de autocorrelação dos resíduos e não corrigiu os problemas de não normalidades dos resíduos. Os vetores de cointegração estimados pelo modelo VEC e seus respectivos coeficientes de ajustamentos de curto prazo são apresentados nas Tabelas 6.7 e 6.8, respectivamente.

Tabela 6.7. Vetor de cointegração normalizado

\begin{tabular}{|c|c|c|c|c|c|c|}
\hline \multirow[b]{2}{*}{ Modelo } & \multirow[b]{2}{*}{ Estatística } & \multicolumn{5}{|c|}{ Variáveis } \\
\hline & & Investimento (In) & Crédito (In) & $\begin{array}{r}\text { Retorno } \\
\text { esperado } \\
\text { do capital }\end{array}$ & $\begin{array}{r}\text { Taxa real } \\
\text { de câmbio }\end{array}$ & $\begin{array}{r}\text { Preço } \\
\text { relativo } \\
\text { do capital }\end{array}$ \\
\hline \multirow[t]{2}{*}{$\mathrm{i}$} & $\beta$ & 1,0000 & $-0,8214$ & $-28,2292$ & & \\
\hline & p-valor & & 0,0000 & 0,0000 & & \\
\hline \multirow[t]{2}{*}{ ii } & $\beta$ & 1,0000 & $-0,7303$ & $-48,1618$ & 2,2851 & \\
\hline & $\mathrm{p}$-valor & & 0,0000 & 0,0000 & 0,2310 & \\
\hline \multirow[t]{2}{*}{ iii } & $\beta$ & 1,0000 & $-0,7993$ & $-27,0508$ & & $-0,6913$ \\
\hline & p-valor & & 0,0000 & 0,0000 & & 0,7140 \\
\hline
\end{tabular}


Tabela 6.8. Coeficientes de ajustamento de curto prazo

\begin{tabular}{|c|c|c|c|c|c|c|}
\hline \multirow[b]{2}{*}{ Modelo } & \multirow[b]{2}{*}{ Estatística } & \multicolumn{5}{|c|}{ Variáveis } \\
\hline & & Investimento (In) & Crédito (In) & $\begin{array}{r}\text { Retorno } \\
\text { esperado } \\
\text { do capital }\end{array}$ & $\begin{array}{r}\text { Taxa real } \\
\text { de câmbio }\end{array}$ & $\begin{array}{r}\text { Preço } \\
\text { relativo } \\
\text { do capital } \\
\end{array}$ \\
\hline \multirow[t]{2}{*}{$\bar{i}$} & $\alpha$ & $-0,0290$ & $-0,0500$ & 0,0008 & & \\
\hline & $\mathrm{p}$-valor & 0,0000 & 0,0050 & 0,2130 & & \\
\hline \multirow[t]{2}{*}{ ii } & $\alpha$ & $-0,0157$ & $-0,0314$ & 0,0005 & $-0,0002$ & \\
\hline & p-valor & 0,0000 & 0,0010 & 0,1740 & 0,9620 & \\
\hline \multirow[t]{2}{*}{ iii } & $\alpha$ & $-0,0306$ & $-0,0523$ & 0,0008 & & 0,0009 \\
\hline & p-valor & 0,0000 & 0,0040 & 0,2290 & & 0,8670 \\
\hline
\end{tabular}

Fonte: Cálculos próprios.

Os resultados da estimação do modelo (i) são muito bons. A cointegração resultou significativa - chi $^{2}=7.629,845, p>\operatorname{chi}^{2} 0,0000$. Foi identificada uma relação positiva e significativa entre o investimento e a produtividade marginal do capital, e entre o investimento e o crédito. Segundo as estimativas do modelo (i), o investimento atuou corrigindo os desequilíbrios de curto prazo conforme indicam as equações (6.1) a seguir, em que It é o investimento, $r_{t} e_{t}$ é o retorno esperado do capital e $B_{t}$ é o crédito. ${ }^{67}$

(6.1) $I_{t}=28,229 \cdot r^{e}{ }_{t}+0,821 \cdot B_{t}$ e $\Delta I_{t}=-0,029 \cdot\left(I_{t-1}-28,229 \cdot r^{e}{ }_{t}-0,821 \cdot B_{t-1}\right)$.

O modelo (ii) acrescentou a taxa de câmbio na análise. A cointegração foi significativa - chi $^{2}=3.050,781, p>\operatorname{chi}^{2} 0,0000$ e confirmou as relações positivas e significativas de longo prazo entre o investimento, o retorno do capital e o crédito. A relação com o câmbio foi negativa, como esperado teoricamente ${ }^{68}$, porém não significativa. Segundo as estimativas do modelo (ii), o investimento atua corrigindo os desequilíbrios de curto prazo conforme indicam as equações (6.2) a seguir, em que $e_{t}$ é a taxa de câmbio real. ${ }^{69}$

(6.2) $I_{t}=48,162 \cdot r^{e}+0,730 \cdot B_{t}-2,285 \cdot e_{t}$ e $\Delta I_{t}=-0,016 \cdot\left(I_{t-1}-48,162 \cdot r^{e}{ }_{t}-0,730 \cdot B_{t-1}+2,285 \cdot e_{t-1}\right)$.

Na terceira relação foi testada a substituição da taxa de câmbio real pelo preço relativo do capital. Os resultados obtidos foram semelhantes aos do modelo (ii). A equação de cointegração foi significativa $-\operatorname{chi}^{2}=9.231,299, p>\operatorname{chi} 20,0000$ e teve coeficiente próximo ao do modelo (ii) para a variável crédito. Todos os coeficientes são significativos como

\footnotetext{
${ }^{67}$ A variável $B_{t}$ tem coeficiente $\alpha$ significativo, mas o sinal é contrário ao correto. Assim, ela não entra no sistema como uma variável que corrige os desvios de curto prazo.

${ }^{68}$ Deve-se ter em mente que no presente capítulo, a taxa de câmbio foi definida em termos de R\$ por US\$, o contrário do que foi empregado no Capítulo 3. Assim, um efeito positivo naquela definição corresponde a um efeito negativo na definição adotada neste capítulo. A opção por mudar o conceito de câmbio buscou adaptar a análise desenvolvida neste capítulo com a abordagem dos demais autores que empregaram séries de tempo para analisar o caso brasileiro.

${ }^{69}$ A variável $B_{t}$ tem coeficiente $\alpha$ significativo, mas o sinal é contrário ao correto como no caso anterior.
} 
aponta a Tabela 6.7, com exceção do preço relativo do capital $\left(1 / Q_{t}\right)$. O investimento também atua corrigindo os desequilíbrios de curto prazo. ${ }^{70}$

(6.3) $I_{t}=27,051 \cdot r^{e}{ }_{t}+0,799 \cdot B_{t}+0,691 \cdot \frac{1}{Q_{t}}$ e $\Delta i=-0,031 \cdot\left(i_{t-1}-27,051 \cdot r^{e}{ }_{t}-0,799 \cdot B_{t-1}-0,691 \cdot \frac{1}{Q_{t-1}}\right)$.

Os coeficientes estimados na Tabela 6.7 não são diretamente comparáveis aos obtidos no Capítulo 3. Para comparar as relações estimadas com séries de tempo com aquelas obtidas em painel é necessário estimar uma regressão em diferenças das variáveis do modelo em nível. A Tabela A.6.3.5 traz esses coeficientes para os modelos (i), (ii) e (iii). Nota-se que os coeficientes associados ao crédito ficaram entre 0,1201 e 0,1523 , valores próximos aos obtidos na Tabela 3.8 nos modelos com taxa de juros e taxa real de câmbio. Os coeficientes associados ao retorno esperado do capital estimados na Tabela A.6.3.5 (valores entre 3,8357 e 3,9640) também estão próximos do valor estimado no Capítulo $3(3,215)$.

\subsection{Quebras estruturais}

Esta seção avalia a presença de quebras estruturais que possam intervir nos resultados dos testes de cointegração. Como visto na introdução deste capítulo, parece haver pontos de quebra nas séries de investimento e de oferta de crédito. É preciso analisar se esses pontos interferem na relação de longo prazo encontrada na subseção anterior. Deve-se observar, também, que há três pontos que representam quebras na série de preço relativo do capital: 1970, 1989 e 1990, os quais podem prejudicar os resultados. O primeiro corresponde a uma mudança metodológica na série e os demais correspondem a um período de inflação muito elevada e instável.

Para avaliar essa questão, foi aplicado, em primeiro lugar, o teste de raiz unitária de Zivot e Andrews (1992), o qual testa a possibilidade das séries serem integradas sem quebra estrutural contra a hipótese das séries serem estacionárias com quebra estrutural ao redor de um ponto desconhecido no tempo. Uma breve descrição do teste é feita no Anexo 6.4. A Tabela 6.9 traz os resultados dos testes para as séries analisadas. O número de defasagens foi determinado pelo critério de significância da maior defasagem. $O$ teste foi feito sob o modelo com constante apenas. De acordo com o teste, pode-se concluir que todas as séries são integradas sem quebra estrutural.

\footnotetext{
${ }^{70}$ No modelo (iii), o retorno esperado do capital tem coeficiente $\alpha$ significativo, mas o sinal é contrário ao esperado.
} 
Tabela 6.9. Teste de raiz unitária de Zivot e Andrews

\begin{tabular}{lcccc}
\hline Variáveis & $\begin{array}{c}\text { Número de } \\
\text { defasagens }\end{array}$ & $\begin{array}{c}\text { Estatística } \\
\text { do teste }\end{array}$ & VC à $5 \%$ & Conclusão \\
\hline Investimento $(\mathrm{In})$ & 0 & $-3,86$ & $-4,800$ & $1 \mathrm{RU}$ \\
Crédito $(\mathrm{In})$ & 0 & $-3,66$ & $-4,800$ & $1 \mathrm{RU}$ \\
Retorno esperado do capital & 1 & $-3,85$ & $-4,800$ & $1 \mathrm{RU}$ \\
Taxa real de câmbio $(\mathrm{In})$ & 0 & $-4,21$ & $-4,800$ & $1 \mathrm{RU}$ \\
Preço relativo do capital & 0 & $-4,21$ & $-4,800$ & $1 \mathrm{RU}$ \\
\hline
\end{tabular}

Fonte: Cálculos próprios. Notas: (1) O teste corresponde ao modelo com apenas intercepto para todas as séries.

Na sequência foi aplicado um teste de cointegração para avaliar se uma possível quebra estrutural estaria afetando as relações de longo prazo estimadas. $\mathrm{O}$ teste aplicado foi proposto por Gregory e Hansen (1996), o qual é baseado no teste de cointegração de Engle e Granger (1987). Ele é um teste em duas etapas que se baseia nos resíduos da regressão estimada e pressupõe uma quebra estrutural endógena, entendida como uma quebra num ponto desconhecido do tempo o qual é determinado pelo modelo. Uma breve descrição do teste também é feita no Anexo 6.4. Os resultados das estimativas de Gregory e Hansen (1996) são comparáveis com o teste de cointegração de Engle e Granger (1987).

A Tabela A.6.5.1 traz as regressões estimadas por MQO que geram os resíduos empregados nos testes de cointegração. A Tabela 6.10 traz as estatísticas $\mathrm{ADF}$ e $\mathrm{ADF}^{*}$, que correspondem aos testes de raiz unitária dos resíduos das regressões estimadas. A primeira estatística refere-se a metodologia de Engle e Granger (1987) e a segunda corresponde ao teste de Gregory e Hansen (1996).

Os resultados dos testes de cointegração de Engle e Granger (1987) indicaram a rejeição da hipótese nula de não cointegração, concluindo que existe uma relação estável de longo prazo entre as variáveis analisadas nos três modelos. O teste de Gregory e Hansen (1996) também indicou a rejeição da hipótese nula de não cointegração, mesmo na presença de quebras estruturais. Ele também apontou para uma possível quebra estrutural no ano de 1996, no caso dos modelos (i) e (iii), e de 1995 para o modelo (ii). Assim, as relações de longo prazo entre as variáveis independem da ocorrência ou não de quebra estrutural, um resultado que reafirma as conclusões do Capítulo 3.

Tabela 6.10. Resultados do teste de Cointegração com quebra estrutural endógena

\begin{tabular}{llrr}
\hline Modelo $^{1}$ & & ADF & ADF $^{*}$ \\
\hline i & Estatística & $-2,0480$ & $-5,6100$ \\
& VC a 5\% & $-1,9500$ & $-4,9200$ \\
\hline ii & Estatística & $-3,2030$ & $-6,0400$ \\
& VC a 5\% & $-1,9500$ & $-5,2800$ \\
\hline iii & Estatística & $-2,6080$ & $-5,5500$ \\
& VC a 5\% & $-1,9500$ & $-5,2800$ \\
\hline
\end{tabular}




\subsection{Os efeitos na acumulação de capital e no crescimento econômico}

As equações (2.24) a (2.28) do Capítulo 2 definiram a contabilidade do crescimento, a função investimento e os efeitos parciais das variáveis determinantes do investimento sobre a evolução no tempo das taxas de acumulação de capital e de crescimento econômico de um país. Essa decomposição foi aplicada no Capítulo 3 para discutir os efeitos dos determinantes do investimento sobre a acumulação de capital e o crescimento econômico. Nesta seção, aquela metodologia é empregada para analisar esses efeitos no processo de crescimento econômico brasileiro entre 1953 e 2013.

Como não há informações sobre as participações dos fatores na renda brasileira para todo o período, a alternativa para implantar as fórmulas de contabilidade de crescimento foi utilizar participação esperada na renda de cada fator de produção, que é dada por:

$$
\lambda_{j}=\frac{\varepsilon_{j}}{R T S}, j=K, L \text { e } R T S=\sum_{j} \varepsilon_{j} .
$$

Isso permite decompor o crescimento da economia brasileira para todo o período, tomando por base os valores das elasticidades $\varepsilon_{K}$ e $\varepsilon_{L}$ estimadas pela fronteira mundial de produção (Anexo 6.1). A Tabela 6.11 traz a decomposição do crescimento econômico para o período entre 1953 e 2013, subdividido em cinco fases que mostram a evolução da história econômica do país. A Tabela 6.12 traz as variações dessas taxas entre os subperíodos.

Tabela 6.11. Decomposição do crescimento, Brasil, 1953 a 2013 (\% ao ano)

\begin{tabular}{lrrrr}
\hline Período & $g_{\curlyvee}$ & $g_{A}$ & $\lambda_{K}^{*} g_{K}$ & $\lambda_{N}{ }^{*} g_{N}$ \\
\hline 1953 a 1967 & $6,4 \%$ & $1,0 \%$ & $4,1 \%$ & $1,3 \%$ \\
1967 a 1980 & $8,9 \%$ & $2,7 \%$ & $4,8 \%$ & $1,4 \%$ \\
1980 a 1994 & $1,9 \%$ & $-2,2 \%$ & $2,6 \%$ & $1,5 \%$ \\
1994 a 2003 & $2,2 \%$ & $-0,1 \%$ & $1,3 \%$ & $0,9 \%$ \\
2003 a 2013 & $3,7 \%$ & $1,4 \%$ & $1,7 \%$ & $0,6 \%$ \\
\hline 1953 a 2013 & $4,8 \%$ & $0,5 \%$ & $3,1 \%$ & $1,2 \%$ \\
\hline
\end{tabular}

Fonte: IBGE e Anexo 6.1. Cálculos próprios.

O crescimento econômico brasileiro foi fortemente impulsionado pela acumulação de capital nesses 60 anos. Entre 1953 e 2013, a acumulação de capital foi responsável por $66 \%$ da taxa de crescimento médio do PIB, que foi de 4,8\% ao ano. No primeiro subperíodo, o país observou elevada taxa de crescimento do PIB (6,4\% ao ano) que foi, em sua maior parte $(65,0 \%)$, determinada pelo processo de acumulação de capital, cuja contribuição foi 4,1\% ao ano. O crescimento do estoque de capital foi induzido pelas políticas de substituição de importações e pelo investimento governamental.

Entre 1967 e 1980, a taxa de crescimento do PIB foi ainda mais elevada: 8,9\% ao ano. Essa expansão também foi impulsionada pela taxa anual de acumulação de capital que 
cresceu 0,6 ponto percentual (Tabela 6.12) entre os dois períodos, respondendo por $53,6 \%$ da taxa de crescimento econômico. Mas a maior parte do aumento da taxa de crescimento é explicada pela variação da taxa anual de crescimento da produtividade, que aumentou 1,8 ponto percentual entre os dois subperíodos. Essa segunda fase, como visto no Capítulo 4, foi marcada pela consolidação das reformas do sistema financeiro e por planos de desenvolvimento econômico (PED, I e II PND) que alavancaram a acumulação de capital no país.

Tabela 6.12. Variações das taxas médias anuais de crescimento, Brasil, em pontos percentuais

\begin{tabular}{lrrrr}
\hline Período & $d g_{\gamma} / d t$ & $d g_{A} / d t$ & $\lambda_{K}{ }^{*} d g_{K} / d t$ & $\lambda_{N}{ }^{*} d g_{N} / d t$ \\
\hline De 1953 a 1967 para 1967 a 1980 & 2,6 p.p. & 1,8 p.p. & 0,6 p.p. & 0,2 p.p. \\
De 1967 a 1980 para 1980 a 1994 & $-7,0$ p.p. & $-4,9$ p.p. & $-2,2$ p.p. & 0,1 p.p. \\
De 1980 a 1994 para 1994 a 2003 & 0,3 p.p. & 2,1 p.p. & $-1,2$ p.p. & $-0,6$ p.p. \\
De 1994 a 2003 para 2003 a 2013 & 1,6 p.p. & 1,4 p.p. & 0,4 p.p. & $-0,2$ p.p. \\
\hline De 1953 a 1967 para 2003 a 2013 & $-2,6$ p.p. & 0,4 p.p. & $\mathbf{- 2 , 4 ~ p . p . ~}$ & $-\mathbf{0 , 6}$ p.p. \\
\hline
\end{tabular}

Fonte: IBGE e Anexo 6.1. Cálculos próprios.

O subperíodo de 1980 a 1994 foi marcado pela crise econômica que envolveu, externamente, o segundo choque do petróleo e a elevação das taxas de juros internacionais e, internamente, uma inflação crescente e a crise no balanço de pagamentos. Observou-se uma taxa de crescimento do PIB relativamente baixa nesse período (1,9\% ao ano) e uma queda forte no ritmo de acumulação de capital, cuja taxa média anual caiu 2,2 pontos percentuais em relação ao subperíodo anterior. Ainda assim, a contribuição da acumulação de capital excedeu o crescimento econômico nesse subperíodo. O crescimento econômico foi negativamente impacto pela queda de $2,2 \%$ ao ano da produtividade - a taxa anual de crescimento da produtividade foi 4,9 pontos percentuais menor que a do subperíodo anterior.

O controle do processo inflacionário a partir de 1994 construiu uma base mínima para a retomada do investimento e da acumulação de capital no país. Entre 1994 e 2003, observou-se taxa de crescimento do PIB de 2,2\% ao ano, com uma contribuição de $61,9 \%$ da acumulação de capital. Mas como indica a Tabela 6.12, houve uma redução da parcela do crescimento econômico que pode ser atribuída à acumulação de capital entre os subperíodos 1980-1994 e 1994-2003 - $\lambda_{K} * d g_{K} / d t$ foi de $-1,2$ ponto percentual.

Finalmente, o subperíodo entre 2003 e 2013 foi marcado por uma recuperação do ritmo de crescimento econômico. Em relação ao subperíodo anterior, a taxa anual de crescimento do PIB aumentou 1,6 ponto percentual. Nesse subperíodo, a taxa de crescimento do PIB foi de 3,7\% ao ano, com aumentos das taxas médias anuais de elevação da produtividade e de acumulação de capital em relação ao subperíodo anterior. 
A última linha da Tabela 6.12 mostra as variações nas taxas de crescimento entre os subperíodos 2003-2013 e 1953-1967, que são as somas das variações entre todos subperíodos. Nessa comparação, a queda na taxa de crescimento econômico foi de 2,6 pontos percentuais, sendo que a maior parte dessa variação deveu-se à que de 2,4 pontos percentuais da taxa de acumulação de capital (já ponderada por seu peso esperado na renda).

Partes expressivas desses movimentos nas taxas de crescimento econômico e de acumulação do capital podem ser explicadas pelas variações observadas no crédito e na taxa de retorno do capital. A Tabela 6.13 traz os efeitos parciais da evolução do crédito e do retorno esperado do capital nas taxas de crescimento do PIB e do estoque de capital, considerando as estimativas apresentadas na Tabela A.6.5.2.

A primeira fase correspondeu ao período de formação do BNDE, momento em que o banco teve dificuldades com a captação de recursos - a inflação corroía o valor do adicional do imposto de renda, a principal fonte de recursos para o banco. Os valores de empréstimos de longo prazo ainda eram baixos e voltados a setores bem específicos, mas o seu ritmo de crescimento foi elevado: $19,7 \%$ ao ano.

As reformas de 1965 aumentaram a oferta de crédito de longo prazo na economia. A criação do Banco Central do Brasil, a instituição da correção monetária, a segmentação do mercado de crédito e a criação do Banco Nacional da Habitação para o financiamento habitacional aumentaram a intermediação financeira, revertendo a trajetória de estagnação econômica e recuperando a capacidade de poupança e de investimento do país. O crescimento da oferta de crédito de longo prazo foi de 19,4\% ao ano entre 1967 e 1980 - Gráfico 6.3. Vale destacar que, nesse período, houve uma elevação das fontes de recursos do BNDE com o PIS/PASEP, os quais permitiram a ampliação da oferta de crédito de longo prazo a partir desse ano. Esse ritmo elevado de crescimento da oferta de crédito teve um efeito expressivo na taxa de acumulação de capital e no crescimento do PIB do país.

De acordo com as estimativas de efeitos parciais apresentadas na Tabela 6.13, o ritmo de crescimento da oferta de crédito provocou uma variação de 0,27 ponto percentual na taxa média anual de acumulação de capital entre os subperíodos 1953-1967 e 1967-1980. O efeito parcial na variação da taxa média anual de crescimento econômico foi de 0,15 ponto percentual. O retorno esperado do capital, por outro lado, apresentou efeito parcial negativo sobre os ritmos de acumulação e de crescimento do PIB, pois houve uma variação negativa da taxa de retorno do capital entre os dois subperíodos, que passou de $41,1 \%$, na média entre 1953 e 1967, para 39,2\%, na média entre 1967 e 1980 - Gráfico 6.4. 
Tabela 6.13. Efeitos parciais* do crédito e do retorno do capital nas taxas anuais de crescimento do PIB e do estoque de capital, Brasil, em pontos percentuais

\begin{tabular}{|c|c|c|c|c|c|c|}
\hline \multirow[b]{2}{*}{ Subperíodo } & \multicolumn{3}{|c|}{$\begin{array}{l}\text { Efeito na taxa média anual } \\
\text { de crescimento do PIB }\end{array}$} & \multicolumn{3}{|c|}{$\begin{array}{l}\text { Efeito na taxa média anual } \\
\text { de acumulação de capital }\end{array}$} \\
\hline & Crédito & $\begin{array}{r}\text { Retorno } \\
\text { esperado } \\
\text { do capital }\end{array}$ & Conjunto** & Crédito & $\begin{array}{r}\text { Retorno } \\
\text { esperado } \\
\text { do capital }\end{array}$ & Conjunto** \\
\hline De 1953 a 1967 para 1967 a 1980 & 0,15 p.p. & $-0,03$ p.p. & $-0,32$ p.p. & 0,27 p.p. & $-0,06$ p.p. & $-0,58$ p.p. \\
\hline De 1967 a 1980 para 1980 a 1994 & $-0,02$ p.p. & $-0,29$ p.p. & $-1,12$ p.p. & $-0,04$ p.p. & $-0,51$ p.p. & $-1,98$ p.p. \\
\hline De 1980 a 1994 para 1994 a 2003 & 0,09 p.p. & $-0,03$ p.p. & $-0,18$ p.p. & 0,14 p.p. & $-0,05$ p.p. & $-0,31$ p.p. \\
\hline De 1994 a 2003 para 2003 a 2013 & 0,05 p.p. & 0,05 p.p. & 0,03 p.p. & 0,09 p.p. & 0,08 p.p. & 0,05 p.p. \\
\hline De 1953 a 1967 para 2003 a 2013 & 0,27 p.p. & $-0,30$ p.p. & $-1,60$ p.p. & 0,46 p.p. & $-0,53$ p.p. & $-2,83$ p.p. \\
\hline
\end{tabular}

Fonte: IBGE, BNDES e Anexo 6.1. Cálculos próprios. (*) Os efeitos foram estimados considerando os coeficientes da Tabela A.6.3.5 (modelo i). (**) Inclui o segundo elemento da equação (2.28).

Gráfico 6.3. Evolução do crédito BNDES, (\% ao ano)

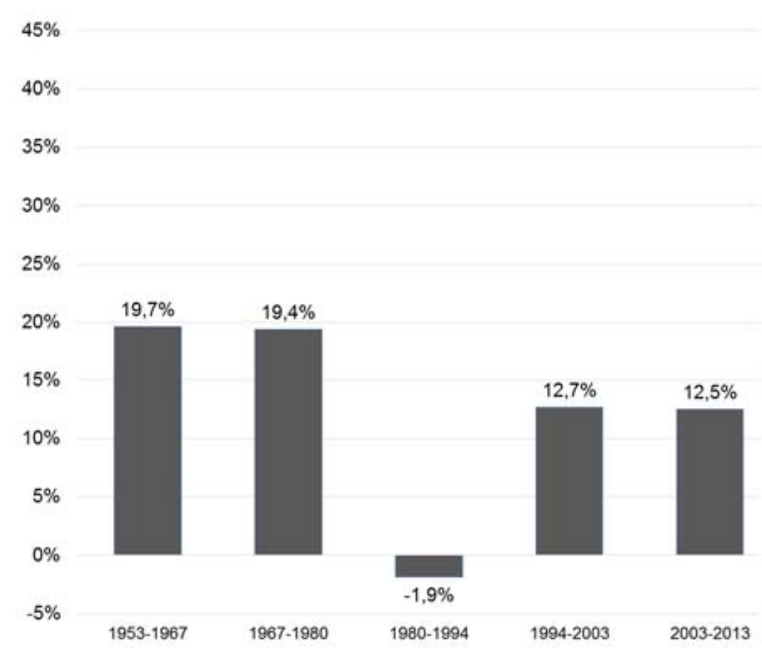

Fonte: BNDES e IBGE. Cálculos próprios.
Gráfico 6.4. Evolução do retorno esperado do capital, (\%)

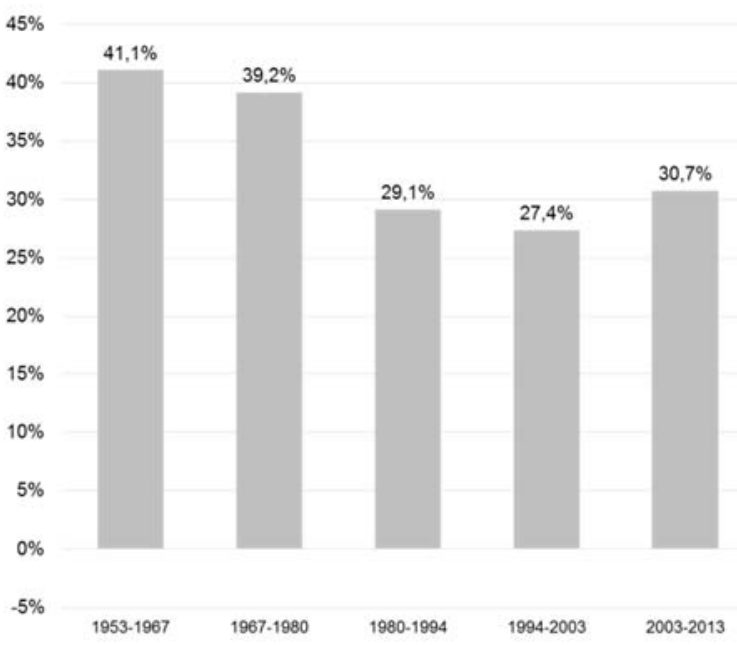

Fonte: Anexo 3.1. Cálculos próprios.

Entre 1980 e 1994, houve queda real de 1,9\% ao ano na oferta de crédito de longo prazo. Os reajustes de ativos e passivos do SFH perderam sincronia, levando a falência e extinção do $\mathrm{BNH}$, a fonte de financiamento do investimento habitacional. A taxa de retorno do capital caiu ainda mais, passando para $29,1 \%$ na média do subperíodo. Com isso, o efeito parcial da oferta de crédito nas variações das taxas médias anuais de crescimento do PIB e do estoque de capital entre 1967-1980 e 1980-1994 foram negativas.

A partir de 1994, foram implantadas mudanças institucionais que objetivaram aumentar a oferta de crédito e elevar o retorno do capital. As privatizações dos setores de telecomunicações e energia elétrica, as concessões, a alienação fiduciária, a criação do Sistema de Financiamento Imobiliário, o marco regulatório do petróleo e a lei de responsabilidade fiscal são exemplos. Essas medidas contribuíram, em diferentes medidas, para reverter o processo de estagnação das taxas de acumulação de capital e de crescimento do PIB. Entre 1994 e 2003, a taxa de crescimento da oferta de crédito foi de 12,7\% ao ano (Gráfico 6.3), mas a taxa de retorno esperada continuou a cair em relação ao período anterior, passando 
para $27,4 \%$. Esses fatores levaram a um aumento de 0,14 ponto percentual, entre esse subperíodo e o anterior, na taxa média de acumulação de capital e de 0,09 ponto percentual na taxa média de crescimento do PIB. Os impactos da queda do retorno esperado do capital sobre as taxas médias de crescimento do PIB e de acumulação de capital foram negativos: de $-0,05$ ponto percentual e $-0,03$ ponto percentual, respectivamente.

O subperíodo 2003-2013 foi marcado por um conjunto ainda mais expressivo de mudanças institucionais que afetaram a oferta de crédito (por meio da redução do risco dos credores) e o retorno dos empreendedores, com efeitos positivos sobre os ritmos de acumulação de capital e de crescimento econômico. Também nessa época, observou-se a recuperação das condições fiscais do governo federal, o que possibilitou a ampliação dos subsídios ao investimento de 2007 em diante. Os Programas de Aceleração do Crescimento (PAC) e o Programa Mina Casa Minha Vida (PMCMV) trouxeram recursos de subsídios para complementar o custeio do investimento nas áreas de habitação e infraestrutura (saneamento, transportes, energia etc.). Como discutido no Capítulo 2, os subsídios reduzem o risco dos bancos, aumentando o retorno esperado e a oferta de crédito.

Nesse subperíodo, a taxa de crescimento do crédito de longo prazo foi de $12,5 \%$ ao ano e a taxa média de retorno esperado do capital elevou-se para 30,7\%. Considerando as variações conjuntas do crédito e do retorno esperado do capital, tanto a taxa de acumulação de capital quanto a de crescimento do PIB deveriam aumentar ligeiramente entre os subperíodos 2003-2013 e 1994-2003. O aumento observado entre os dois subperíodos na taxa média anual de crescimento econômico foi de 1,6 ponto percentual, o que indica que outros fatores, provavelmente ligados à evolução da produtividade, influenciaram positivamente a evolução da taxa de crescimento do PIB. ${ }^{71}$

É importante observar que, nesses 60 anos, a expansão do crédito e a evolução do retorno esperado do capital responderam por uma grande parcela da variação da taxa de crescimento do PIB. A estimativa dos efeitos conjuntos acumulados dessas variáveis sobre a taxa de acumulação de capital é de uma redução de 2,8 pontos percentuais entre os subperíodos final (2003-2013) e inicial (1953-1967). De fato, as estatísticas calculadas com base nos dados do IBGE mostram que a taxa brasileira de acumulação de capital caiu 4,6 pontos percentuais entre esses subperíodos. De outro lado, como indica a Tabela 6.13, a estimativa do efeito conjunto acumulado dessas variáveis sobre a taxa de crescimento econômico é de uma redução de aproximadamente 1,6 ponto percentual entre os subperíodos. A compara-

\footnotetext{
${ }^{71} \mathrm{O}$ resultado para esse período diverge do verificado no Capítulo 3, o qual foi baseado em outra base de dados e em diferenças de períodos ligeiramente distintas. Esse ponto será discutido novamente no próximo capítulo.
} 
ção direta dos ritmos de crescimento econômico nos subperíodos indica uma redução observada de 2,6 pontos percentuais, ou seja, esses dois fatores responderam por algo em torno de $60 \%$ da queda na taxa de crescimento. Esses dados reforçam a ideia de que as dinâmicas de acumulação e de crescimento foram essencialmente determinadas pela evolução do crédito e do retorno do capital nesses anos. 


\section{Capítulo 7}

\section{Crédito e investimento setoriais no Brasil}

O Capítulo 6 mostrou que o investimento total da economia brasileira se recuperou a partir de meados dos anos 2000. Os dados do IBGE empregados naquela análise indicavam crescimento de $6,8 \%$ ao ano da formação bruta de capital fixo entre 2003 e 2013, sendo que no período mais recente (2009 a 2013), a taxa de expansão foi de $6,6 \%$ ao ano. Conclui-se que a ampliação da oferta de crédito e a recuperação do retorno esperado do capital contribuíram positivamente para essa expansão do investimento.

Este capítulo complementa a discussão sobre os determinantes do investimento no Brasil, e seus efeitos sobre a acumulação de capital e o crescimento econômico, com uma análise das relações entre investimento, crédito, retorno do capital e preço de ativos nos diversos setores de atividade da economia. O período de análise vai de 1995 a 2009, intervalo de tempo para o qual há disponibilidade de dados desagregados para essas variáveis. A análise traz uma inovação em relação aos trabalhos empíricos sobre investimento, os quais se baseiam em variáveis agregadas. Com os dados setoriais é possível verificar se os resultados discutidos anteriormente se mantêm, ou ainda, se as relações entre essas variáveis são semelhantes num plano menos agregado da economia. Essa avaliação traz informações ainda inexploradas na literatura (dados do WIOD sobre investimento) e dados sobre crédito que foram construídos para a avaliação empírica e econométrica feita neste capítulo.

Antes de iniciar a avaliação econométrica, cabe analisar a evolução do investimento, do crédito e do retorno do capital nos diferentes setores de atividade da economia brasileira nesse período. A Tabela 7.1 traz a evolução do investimento do crédito e do retorno do capital $^{72}$ entre 1995 e 2009 para 31 setores de atividade. As informações são provenientes de duas bases de dados: (i) o World Input-Output Database (WIOD) ${ }^{73}$ e (ii) uma

\footnotetext{
72 Os dados do WIOD parecem superestimar as taxas brutas de retorno do capital nos segmentos de telecomunicação e nas atividades financeiras. Provavelmente isso se deve a problemas de medida no denominador da taxa, que é a estimativa de estoque de capital.

${ }^{73}$ No agregado, os dados de investimento do IBGE e do WIOD têm diferenças relevantes, pois usam deflatores distintos. Para se ter uma ideia dessas diferenças, vale notar que, segundo o WIOD, a taxa média real de expansão do investimento verificada entre 1995 a 2009 foi de $7,3 \%$ ao ano, enquanto que a série do IBGE indica crescimento de 2,6\% ao ano nesse mesmo período. Os dados de estoque de capital empregados neste capítulo também não são iguais aos utilizados no Capítulo 6. Aqui, o estoque de capital vem do WIOD e corresponde ao agregado dos estoques setoriais. No Capítulo 6, o estoque foi construído pelo método de inventário perpétuo, considerando os dados do IBGE e de Ronci (1987).
} 
base de dados sobre crédito construída com informações do BNDES e do Banco Central do Brasil (ver Anexo 7.1).

Tabela 7.1. Investimento, crédito e retorno do capital, 1995 a 2009, Brasil, médias e variações anuais $(\%)$

\begin{tabular}{|c|c|c|c|c|c|c|}
\hline \multirow[b]{2}{*}{ Setores } & \multicolumn{3}{|c|}{ Média* } & \multicolumn{3}{|c|}{ Variação anual** } \\
\hline & $\begin{array}{r}\text { Investimen- } \\
\text { to (em In) }\end{array}$ & $\begin{array}{l}\text { Crédito } \\
\text { (em In) }\end{array}$ & $\begin{array}{r}\text { Retorno } \\
\text { do Capital } \\
\end{array}$ & $\begin{array}{r}\text { Investi- } \\
\text { mento }\end{array}$ & Crédito & $\begin{array}{r}\text { Retorno } \\
\text { do Capital } \\
\end{array}$ \\
\hline Agropecuária & 23,238 & 21,340 & $29,0 \%$ & $5,4 \%$ & $9,3 \%$ & $-0,8 \%$ \\
\hline Indústria Extrativa & 24,063 & 20,378 & $11,7 \%$ & $11,5 \%$ & $25,5 \%$ & $-2,4 \%$ \\
\hline Produtos Alimentícios, bebidas e fumo & 22,896 & 21,331 & $16,5 \%$ & $5,7 \%$ & $9,8 \%$ & $-9,1 \%$ \\
\hline Têxtil, confec., vestuário e acessórios & 21,327 & 19,510 & $25,0 \%$ & $6,4 \%$ & $0,4 \%$ & $-2,5 \%$ \\
\hline Couro, artefato e calçado & 20,409 & 18,656 & $12,8 \%$ & $6,7 \%$ & $5,6 \%$ & $-3,5 \%$ \\
\hline Madeira & 21,652 & 18,847 & $15,3 \%$ & $8,7 \%$ & $8,9 \%$ & $-17,9 \%$ \\
\hline Celulose, papel e gráfica & 23,764 & 20,578 & $8,9 \%$ & $9,8 \%$ & $13,2 \%$ & $-11,2 \%$ \\
\hline Coque, petróleo e combustível & 23,357 & 21,381 & $15,1 \%$ & $12,6 \%$ & $34,3 \%$ & $-3,0 \%$ \\
\hline Química, farmoquímico e farmacêutico & 22,502 & 20,319 & $26,7 \%$ & $7,1 \%$ & $12,2 \%$ & $-1,3 \%$ \\
\hline Borracha e plástico & 21,427 & 19,458 & $16,4 \%$ & $7,2 \%$ & $6,4 \%$ & $-4,8 \%$ \\
\hline Mineral não metálico & 20,924 & 19,352 & $23,0 \%$ & $8,8 \%$ & $8,4 \%$ & $0,7 \%$ \\
\hline Produto de metal e metalurgia & 22,980 & 21,077 & $20,3 \%$ & $9,1 \%$ & $14,0 \%$ & $-1,9 \%$ \\
\hline Máquinas e equipamentos & 21,455 & 20,360 & $22,8 \%$ & $7,9 \%$ & $9,8 \%$ & $-3,9 \%$ \\
\hline Equip. info. eletrônico, ótico, máq. e aparelho elétrico & 21,280 & 20,340 & $36,8 \%$ & $9,5 \%$ & $13,8 \%$ & $0,2 \%$ \\
\hline Veículo, carroceria e outros equip. transporte & 22,743 & 22,080 & $8,7 \%$ & $8,9 \%$ & $19,7 \%$ & $-8,2 \%$ \\
\hline Móveis e produtos diversos & 20,425 & 18,455 & $51,8 \%$ & $8,3 \%$ & $9,7 \%$ & $-1,9 \%$ \\
\hline Eletricidade, gás, água, esgoto e lixo & 22,803 & 22,249 & $29,0 \%$ & $9,6 \%$ & $19,1 \%$ & $8,7 \%$ \\
\hline Construção & 22,122 & 20,438 & $60,2 \%$ & $4,2 \%$ & $23,4 \%$ & $-5,1 \%$ \\
\hline Comércio & 22,578 & 20,408 & $29,5 \%$ & $2,8 \%$ & $16,6 \%$ & $3,0 \%$ \\
\hline Alojamento e alimentação & 21,613 & 17,980 & $31,1 \%$ & $1,8 \%$ & $-3,4 \%$ & $-11,8 \%$ \\
\hline Transporte terrestre & 22,371 & 22,116 & $18,2 \%$ & $8,2 \%$ & $20,8 \%$ & $2,8 \%$ \\
\hline Transporte aquaviário & 19,725 & 19,415 & $27,0 \%$ & $4,9 \%$ & $8,3 \%$ & $-0,2 \%$ \\
\hline Transporte aéreo & 20,140 & 18,005 & $17,1 \%$ & $5,4 \%$ & $6,5 \%$ & $0,7 \%$ \\
\hline Ativ. Aux. transporte e entrega & 21,601 & 19,651 & $25,4 \%$ & $8,6 \%$ & $21,5 \%$ & $4,2 \%$ \\
\hline Informação, comunicação e telecomunicações & 21,296 & 21,221 & $139,4 \%$ & $8,0 \%$ & $29,0 \%$ & $29,2 \%$ \\
\hline Ativ. financeira e seguro & 21,846 & 19,630 & $230,7 \%$ & $16,4 \%$ & $21,5 \%$ & $16,1 \%$ \\
\hline Ativ. Imobil., profissional e adm. & 24,546 & 22,612 & $7,1 \%$ & $3,9 \%$ & $15,3 \%$ & $0,4 \%$ \\
\hline Administração Pública & 24,064 & 19,210 & $2,8 \%$ & $6,0 \%$ & $37,5 \%$ & $7,4 \%$ \\
\hline Educação & 20,243 & 18,637 & $18,9 \%$ & $12,0 \%$ & $14,7 \%$ & $13,6 \%$ \\
\hline Saúde e serv. social & 21,994 & 18,635 & $41,5 \%$ & $4,8 \%$ & $11,2 \%$ & $-3,6 \%$ \\
\hline Artes, cultura etc. ${ }^{\dagger}$ & 22,799 & 17,763 & $26,8 \%$ & $8,0 \%$ & $8,2 \%$ & $0,7 \%$ \\
\hline Total & 26,206 & 24,299 & $13,6 \%$ & $7,3 \%$ & $16,8 \%$ & $0,7 \%$ \\
\hline
\end{tabular}

Fonte: WIOD, BNDES e Banco Central do Brasil. Nota: Investimento e Crédito em R\$ de 1995. (*) média entre 1995 e 2009. (**) Taxa de variação média anual entre 1995 e 2009. ( $\left.{ }^{\dagger}\right)$ Artes, cultura, esporte, outras atividades de serviços, manutenção, reparação e organismos internacionais.

No período analisado, houve crescimento real dos investimentos em todos os segmentos da economia brasileira, sendo que, na média da economia, o aumento foi de 7,3\% ao ano. Entre os setores de atividade que registraram maior crescimento do investimento estão os de: (i) atividade financeira e seguro; (ii) coque, petróleo e combustível; (iii) educação; e (iv) a indústria extrativa. Todos esses setores tiveram crescimento real da formação bruta de capital fixo de mais de $11 \%$ ao ano no período.

O crédito de longo prazo cresceu 16,8\% ao ano entre 1995 e 2009, com destaque para os setores: (i) administração pública; (ii) coque, petróleo e combustível; (iii) telecomunicação; e (iv) indústria extrativa, todos com taxas de crescimento superiores a 
25\% ao ano. Todos os setores apresentaram taxa de crescimento positiva na média do período, com exceção do setor de alojamento e alimentação, que teve queda no volume de crédito concedido de 3,4\% ao ano entre 1995 e 2009.

No agregado, o Brasil apresentou aumento da taxa de retorno do capital de $0,7 \%$ ao ano entre 1995 e 2009. Alguns setores observaram redução do retorno, como foi o caso do ramo de alojamento e alimentação. Nesse caso, a redução na taxa média de retorno do capital se soma à redução no volume de crédito concedido para explicar o baixo crescimento do investimento no setor.

No geral, os setores com maior taxa de crescimento do investimento tiveram também forte expansão do crédito e ampliação do retorno do capital. A seção seguinte traz a análise de cointegração entre essas variáveis, considerando também a evolução do preço relativo do capital (um indicador do preço de ativos). A seção 7.2 analisa os efeitos da taxa nominal de juros de longo prazo e da taxa real de câmbio sobre o investimento. Essa seção também testa o emprego do retorno esperado do capital na análise da relação de cointegração entre as variáveis, aos moldes do que foi desenvolvido no Capítulo 3. Por fim, a seção 7.3 aplica a metodologia de decomposição para avaliar os efeitos da evolução dos fatores determinantes do investimento na acumulação de capital e do crescimento dos setores de atividade da economia brasileira.

\subsection{Oferta de crédito e investimento agregado setorial}

Para avaliar se a relação de longo prazo entre crédito e investimento se sustenta num nível menos agregado da economia que os analisados nos Capítulos 3 e 6, este capítulo desenvolveu uma análise de painel com os dados setoriais da economia brasileira entre 1995 e 2009 . Essa avaliação seguiu a estrutura da análise internacional do Capítulo 3, a qual avaliou a estacionariedade das séries e a presença de relações de longo prazo entre crédito, investimento, retorno do capital e preço dos ativos. Foram utilizados sete testes de raiz unitária em painel e dois testes de cointegração baseados nos resíduos. A seção 7.1.1 apresenta a base de dados e comenta a metodologia econométrica. Nas seções 7.1.2 e 7.1.3, são apresentados os resultados dos testes e a estimação das relações de longo prazo.

\subsubsection{Base de dados e metodologia}

As variáveis utilizadas na modelagem foram: investimento, crédito, retorno do capital, preço relativo do capital (preço dos ativos), taxa real de câmbio e taxa nominal 
de juros de longo prazo. A amostra foi formada por um painel de 31 setores de atividades, com observações anuais para o período 1995 a 2009, num total de 465 observações. Os setores de atividade foram: agropecuária; mineração; alimentos e bebidas; produtos têxteis; couro e calçados; produtos de madeira; papel e celulose; refino de petróleo; produtos químicos; plástico e borracha; minerais não metálicos; metalurgia; máquinas e equipamentos; material elétrico; equipamentos de transporte; outros produtos industriais; eletricidade, água e gás; construção; comércio de veículos e combustíveis; comércio atacadista; comércio varejista; alojamento e alimentação; transportes terrestres; transporte marítimo; transportes aéreos; serviços auxiliares de transportes; comunicações; intermediação financeira; atividades imobiliárias; serviços prestados às empresas; administração pública; educação; saúde e serviços sociais; e outros serviços.

A base de dados veio de diversas fontes: Word Input-Output Database (WIOD), Banco Nacional de Desenvolvimento Econômico e Social (BNDES) e Banco Central do Brasil. A seguir são apresentadas as definições e as estatísticas descritivas das séries.

- Investimento: corresponde à formação bruta de capital fixo, em milhões de reais de 1995, conforme o deflator do capital calculado pelo World Input-Output Database. A fonte é o WIOD.

- Crédito: esta série foi construída a partir da agregação de várias fontes: (i) desembolso do sistema BNDES por setor de atividade econômica, segundo a Classificação Nacional de Atividades Econômicas (CNAE); (ii) empréstimos concedidos com recursos do FGTS para os setores de habitação, saneamento, Fundo de Arrendamento Social (FAR) e infraestrutura; e (iii) operações contratadas com recursos de poupança SBPE para o setor de habitação. Os valores estão a preços de 1995, considerando o deflator implícito da formação bruta de capital fixo do WIOD. A Tabela A.7.1.1 do Anexo 7.1 traz as classificações de atividades econômicas que permitiram compatibilizar as bases de dados do WIOD e do BNDES.

- Retorno do Capital: essa variável foi calculada a partir de duas outras: a remuneração bruta do capital dividida pelo estoque de capital fixo, ambos a preços de 1995. Os dados foram obtidos no WIOD.

- Retorno esperado do capital: foi definida como a relação entre a parcela esperada pelos capitalistas na distribuição funcional da renda e o estoque de capital. Essa relação mede, portanto, a taxa de retorno esperada do capital. Ela também pode ser entendida como o produto entre a produtividade marginal do capital pela relação capi- 
tal-PIB. A série foi estimada para os 31 setores de atividade entre 1995 e 2009 com base nos dados estoque de capital, no PIB e na elasticidade do PIB em relação ao capital obtida por um modelo econométrico de função de produção dos setores de atividade, cujas estimativas são apresentadas no Apêndice 7.2. ${ }^{74}$

- Taxa de juros de longo prazo: Corresponde à taxa de juros de longo prazo (TJLP) em (\%) ao ano. Note-se que no caso desta série só há dados disponíveis para o total da economia; assim, todos os setores têm a mesma taxa de juros, variando apenas a dimensão temporal do painel.

- Taxa real de câmbio: corresponde ao índice da taxa de câmbio real com base $1 \mathrm{em}$ 1995. Os índices nos anos subsequentes são calculados multiplicando o índice do ano anterior pela variação do câmbio nominal (em US\$ por R\$) e pela variação dos preços locais (deflator implícito do PIB) e dividindo pela variação de preços nos Estados Unidos (deflator implícito do PIB). Os dados vêm do WIOD.

As variáveis investimento e crédito foram transformadas em logaritmo natural. A Tabela 7.2 traz as estatísticas descritivas das variáveis.

Tabela 7.2 Estatísticas descritivas das variáveis

\begin{tabular}{lrrrr}
\hline Variável & Média & $\begin{array}{l}\text { Desvio } \\
\text { padrão }\end{array}$ & Mínimo & Máximo \\
\hline Investimento (In) & 21,9862 & 1,2832 & 19,3791 & 24,9392 \\
Crédito (In) & 19,6750 & 1,6062 & 13,2806 & 23,8262 \\
Retorno do capital (\%) & 0,3372 & 0,5291 & 0,0145 & 5,0111 \\
Retorno esperado do capital (\%) & 0,3261 & 0,2858 & 0,0029 & 1,5037 \\
Preço relativo do capital & 0,7974 & 0,2551 & 0,1221 & 1,7205 \\
Taxa de juros de longo prazo & 0,1085 & 0,0428 & 0,0617 & 0,2371 \\
Taxa real de câmbio & 0,8168 & 0,2134 & 0,5067 & 1,0723
\end{tabular}

Fonte: WIOD, BNDES e Banco Central do Brasil. Nota: para todas as variáveis o banco conta com 465 informações com $N=31$ e $T=15$.

A metodologia econométrica é a mesma aplicada para a análise internacional. ${ }^{75}$ Foram aplicados os testes de raiz unitária em painel de Levin, Lin e Chu (2002), Harris e Tzavalis (1999), Breitung (2000), Im, Pesaran e Shin (2003), Maddala e Wu (1999) e Hadri (2000). Os testes de cointegração aplicados foram aqueles baseados nos resíduos da regressão ${ }^{76}$ - Kao (1999) e Pedroni (2004).

\footnotetext{
${ }^{74}$ Sobre os aspectos teóricos dessa medida de retorno, ver também Anexo 3.3 do Capítulo 3.

${ }^{75}$ Ver Anexo 3.1 com a descrição dos testes de raiz unitária em painel e Anexo 3.2 com a descrição dos testes de cointegração em painel utilizados nesta seção.

${ }^{76}$ A metodologia de Westerlund (2007), que é baseada em um vetor de correção de erros, não pôde ser aplicada porque o $T$ é pequeno. O VEC, por conta das defasagens e antecipações, perde muitos graus de liberdade. Neste caso, em que $T=15$, os testes aplicados a relações entre mais de 2 variáveis não convergem por falta de observações.
} 


\subsubsection{Resultados dos testes de raiz unitária}

$\mathrm{Na}$ aplicação dos testes de raiz unitária, optou-se pelas duas especificações que incluem os termos deterministas (modelo 2 e 3), da mesma forma que foi feito no Capítulo 3. As defasagens foram determinadas pelo critério da significância da maior defasagem, partindo do nível máximo de 5 defasagens. Os resultados dos testes são apresentados na Tabela 7.3. Os asteriscos na tabela indicam a presença de raiz unitária, considerando um nível de significância de 5\%.

Tabela 7.3 Resultados dos testes de RU

\begin{tabular}{|c|c|c|c|c|c|c|c|c|c|c|c|c|c|c|c|c|}
\hline & Variáveis & & $\begin{array}{r}\text { Investimento } \\
\text { (In) }\end{array}$ & & $\begin{array}{r}\text { Crédito } \\
\text { (In) }\end{array}$ & & $\begin{array}{r}\text { Retorno } \\
\text { do Capital }\end{array}$ & & $\begin{array}{r}\text { Retorno } \\
\text { esperado } \\
\text { do capital }\end{array}$ & & $\begin{array}{r}\text { Preço } \\
\text { relativo } \\
\text { do capital }\end{array}$ & & $\begin{array}{l}\text { Taxa de } \\
\text { Câmbio }\end{array}$ & & $\begin{array}{r}\text { Taxa de } \\
\text { juros de } \\
\text { longo } \\
\text { prazo }\end{array}$ & \\
\hline \multirow{5}{*}{$\begin{array}{c}\text { Sem } \\
\text { tendência } \\
\text { (modelo } \\
2 \text { ) }\end{array}$} & \multirow{2}{*}{$\begin{array}{c}\text { H0: Todos } \\
\text { os países } \\
\text { são I(1) } \\
\end{array}$} & LLC & 6,94 & * & 1,69 & * & 0,72 & * & 11,58 & * & 1,53 & * & $-10,05$ & & 23,78 & * \\
\hline & & Breitung & 8,56 & * & 1,75 & * & $-0,25$ & * & 8,33 & * & 2,28 & * & $-3,99$ & & 3,54 & * \\
\hline & \multirow{2}{*}{$\begin{array}{c}\text { H0: Uma } \\
\text { fração de } \\
\text { países são } \\
\text { I(1) }\end{array}$} & IPS & 3,92 & * & 2,94 & * & 0,45 & * & 8,28 & * & 3,49 & * & $-11,07$ & & 6,92 & * \\
\hline & & HT & 5,69 & * & 0,61 & & 0,90 & * & 0,86 & * & 0,72 & & 0,87 & * & 0,50 & \\
\hline & $\begin{array}{l}\text { H0: Todos } \\
\text { os países } \\
\text { são I(0) }\end{array}$ & Hadri & 40,63 & & 18,42 & * & 40,43 & * & 38,39 & * & 30,7527 & * & 6,5995 & * & 26,5672 & * \\
\hline \multirow{5}{*}{$\begin{array}{c}\text { Com } \\
\text { tendência } \\
\text { (modelo } \\
3 \text { ) }\end{array}$} & \multirow{4}{*}{$\begin{array}{c}\text { H0: Uma } \\
\text { fração de } \\
\text { países são } \\
\text { I(1) }\end{array}$} & MW- Dfuller & 183,65 & & 70,69 & * & 49,71 & * & 73,19 & * & 22,67 & * & 128,79 & & 38,00 & * \\
\hline & & MW- Pperon & 14,36 & * & 79,40 & * & 132,79 & & 327,31 & & 116,39 & & 1,23 & * & 1152,73 & \\
\hline & & IPS & $-4,72$ & & 0,36 & * & 1,28 & * & 1,77 & * & 2,61 & * & $-5,80$ & & $-1,37$ & * \\
\hline & & HT & 3,34 & * & 0,37 & & 0,51 & * & 0,84 & * & 0,22 & & 0,92 & * & 0,20 & \\
\hline & $\begin{array}{l}\text { H0: Todos } \\
\text { os países } \\
\text { são I(0) }\end{array}$ & Hadri & 24,08 & * & 10,69 & * & 15,27 & * & 25,98 & * & 7,82 & * & 33,04 & * & 4,70 & * \\
\hline
\end{tabular}

Fonte: Cálculos próprios. Notas: (i) Os resultados com (*) indicam alguma presença de raiz unitária; (ii) o número de defasagens foi determinado pelo critério de significância da maior defasagem.

Em geral, os resultados apontaram para a presença de uma raiz unitária na maioria das variáveis analisada. No caso do teste IPS, os resultados mostraram a presença de uma raiz unitária em todas as variáveis analisadas, com exceção da taxa de câmbio e do investimento. O teste LLC também apontou para uma raiz unitária em todas as variáveis, com exceção da taxa de câmbio e do investimento. De acordo com o teste de Breitung, as séries de investimento, crédito, retorno do capital, taxa de juros de longo prazo e retorno esperado do capital apresentaram uma raiz unitária em ambos os modelos. Os testes do tipo Fisher, proposto por Madalla e Wu (MW-DFuller e MW- PPeron), apresentaram resultados variados, mas a maioria mostrou a presença de uma raiz unitária. $\mathrm{O}$ teste de Hadri, cuja hipótese nula é painel estacionário, mostrou a presença de uma raiz unitária, sem exceção. 


\subsubsection{Resultados dos testes de cointegração em painel}

Como a maioria dos testes apontou para a presença de uma raiz unitária, pode-se assumir a não estacionariedade do painel e aplicar as técnicas de cointegração para analisar a relação entre as variáveis. Os resultados da regressão de painel com efeito fixo entre investimento, crédito, retorno do capital e preço relativo do capital são apresentados na Tabela A.7.3.1 do Apêndice 7.3. Os coeficientes são significativos e têm os sinais esperados. Os resíduos dessa regressão foram utilizados nos testes de cointegração, cujos resultados figuram na Tabela 7.4.

De acordo com o teste de cointegração de Kao (1999), parece haver uma relação estável de longo prazo entre as quatros variáveis, pois os resíduos da regressão de painel são estacionários. Os resultados do teste de Pedroni (2004) são menos conclusivos, pois três estatísticas - panel $v$, panel rho e group rho - não rejeitam a hipótese nula de não cointegração. Contudo, as estatísticas $P P$ e $A D F$ (quatro ao total) rejeitam a hipótese nula de não cointegração, apontando em direção aos resultados encontrados com a metodologia de Kao. Isso sugere que há evidências suficientes de existência de relações estáveis de longo prazo entre as variáveis.

Tabela 7.4. Resultados do teste de cointegração

\begin{tabular}{|c|c|c|c|c|c|}
\hline & \multicolumn{2}{|c|}{ Metodologia do Pedroni } & \multicolumn{3}{|c|}{ Metodologia de Kao } \\
\hline Estatística & Valor & $\mathrm{p}$-valor & & estatística & $\mathrm{p}$-valor \\
\hline Panel v & $-0,11$ & 0,5447 & $P$ & 92,63 & 0,007 \\
\hline Panel rho & 1,10 & 0,8638 & Z & $-2,20$ & 0,014 \\
\hline Panel PP & $-3,70$ & 0,0001 & $L^{*}$ & $-2,36$ & 0,010 \\
\hline Panel ADF & $-3,62$ & 0,0001 & $\mathrm{Pm}$ & 2,75 & 0,003 \\
\hline Group rho & 3,03 & 0,9988 & & & \\
\hline Group PP & $-5,64$ & 0,0000 & & & \\
\hline Group ADF & $-5,14$ & 0,0000 & & & \\
\hline
\end{tabular}

Fonte: Cálculos próprios. Notas: No teste de Kao, não foi usado defasagem, de acordo com o critério da significância da maior defasagem. No teste do Pedroni, foram usadas 2 defasagens de acordo com o critério de informação de Schwarz. Foi considerado o modelo 2 com constante.

As relações de longo prazo podem ser estimadas por meio do modelo DOLS (Dynamics Ordinary Least Squares) proposto por Kao e Chiang (2000). A Tabela 7.5 traz as estimativas das relações entre as cinco variáveis. Os coeficientes são bastante parecidos com as estimativas feitas com o modelo de efeito fixo (Tabela A.7.3.1). Observa-se uma relação positiva entre crédito e investimento, da ordem de 0,1640. Como as duas variáveis foram transformadas em $I n$, esse coeficiente indica a elasticidade do investimento em relação ao crédito. O coeficiente associado ao retorno do capital tem o sinal esperado e é estatisticamente significativo a menos de $1 \%$. O preço relativo do capital apresentou sinal negativo, como esperado, e também bastante significativo. Isso 
indica que, num dado setor de atividade econômica, um aumento do preço de reposição do capital relativamente ao preço dos bens e serviços nele produzidos, reduz o investimento. Em outros termos, se o preço dos bens e serviços do setor cresce em relação ao custo de reposição do capital, há estímulo para o investimento.

Tabela 7.5. Relação de longo prazo, DOLS

\begin{tabular}{lrrrr}
\hline & Coeficiente & Erro padrão & Z & p-valor \\
\hline Crédito (In) & 0,1640 & 0,0219 & 7,50 & 0,0000 \\
Retorno do Capital & 0,2099 & 0,0717 & 2,93 & 0,0030 \\
Preço relativo do capital & $-1,1539$ & 0,1202 & $-9,60$ & 0,0000 \\
\hline$R^{2}$ ajustado & 0,5767 & & & \\
Número de observações: & 403 & & & \\
\hline
\end{tabular}

Fonte: Cálculos próprios. Nota: inclui uma constante por setor de atividade.

Esses resultados não são diretamente comparáveis com os coeficientes apresentados no Capítulo 6, cujas estimativas empregaram dados agregados da economia brasileira para um período de tempo maior (1953 a 2013) e uma mensuração do retorno do capital distinta. Contudo, vale mencionar que os sinais são os mesmos: o crédito e o retorno do capital têm efeitos positivos sobre o investimento e o preço relativo do capital tem efeito negativo.

De outro lado, os resultados deste capítulo podem ser comparados com os achados do Capítulo 3, cujas estimativas foram baseadas num painel internacional de países. Observa-se que, em todos os casos, os testes de cointegração indicam relações estáveis e positivas entre investimento, crédito, retorno do capital e preço relativo do capital. Isso indica que as relações estimadas com dados agregados de economias nacionais também são semelhantes às estimativas feitas com base em uma amostra de dados desagregados da economia brasileira. Vale observar que o coeficiente que relaciona o investimento ao crédito estimado para os setores brasileiros é bem menor que aquele estimado nos demais modelos - séries de tempo, no caso do Brasil e painel internacional de países.

\subsection{Os efeitos da taxa de juros de longo prazo e do retorno esperado do capital}

Para aproximar a análise de cointegração realizada neste capítulo com os resultados encontrados no Capítulo 6, esta seção refaz as análises da seção anterior empregando a taxa de juros de longo prazo e a taxa real de câmbio, duas variáveis importantes na determinação do investimento conforme visto nos Capítulos 1 a 3. Além disso, foi testada a substituição da taxa efetiva de retorno do capital pelo retorno esperado do capital. 
Assim, os três modelos testados nesta seção são: (i) crédito, retorno efetivo do capital, preço relativo do capital e taxa de juros de longo prazo; (ii) crédito, retorno efetivo do capital, preço relativo do capital, taxa de juros de longo prazo e taxa real de câmbio; e (iii) crédito, retorno esperado do capital, preço relativo do capital, taxa de juros de longo prazo e taxa real de câmbio. A Tabela A.7.3.2 do Apêndice 7.3 traz as regressões por efeito fixo dos três modelos que estimam os resíduos empregados nos testes de cointegração.

A Tabela 7.6 traz o teste de cointegração sob os resíduos. Nota-se que, de acordo com o teste de Kao (1999), parece haver relações estáveis de longo prazo nos três casos analisados. O teste do Pedroni (2004) apresentou resultados semelhantes aos da seção anterior: três estatísticas - panel $v$, panel rho e group rho - não rejeitam a hipótese nula de não cointegração e as estatísticas $P P$ e $A D F$ (quatro ao total) rejeitam a hipótese nula de não cointegração, confirmando os resultados encontrados com a metodologia de Kao.

Tabela 7.6. Resultados do teste de cointegração

\begin{tabular}{|c|c|c|c|c|c|}
\hline & \multicolumn{2}{|c|}{ Metodologia do Pedroni* } & \multicolumn{3}{|c|}{ Metodologia de Kao } \\
\hline Estatística & Valor & p-valor & & estatística & p-valor \\
\hline \multicolumn{6}{|c|}{ Relação entre investimento, retorno do capital, preço relativo do capital e taxa de juros } \\
\hline Panel v & $-1,07$ & 0,8573 & $\mathrm{P}$ & 81,91 & 0,0460 \\
\hline Panel rho & 2,69 & 0,9964 & Z & $-1,84$ & 0,0329 \\
\hline Panel PP & $-2,08$ & 0,0187 & $L^{*}$ & $-1,96$ & 0,0262 \\
\hline Panel ADF & $-2,09$ & 0,0185 & ed Pm & 1,79 & 0,0369 \\
\hline Group rho & 4,78 & 1,0000 & & & \\
\hline Group PP & $-3,10$ & 0,0010 & & & \\
\hline Group ADF & $-2,53$ & 0,0057 & & & \\
\hline \multicolumn{6}{|c|}{ Relação entre investimento, retorno do capital, preço relativo do capital, taxa de juros e taxa de câmbio } \\
\hline Panel v & $-1,44$ & 0,9247 & $\mathrm{P}$ & 121,97 & 0,0000 \\
\hline Panel rho & 3,16 & 0,9992 & z & $-4,79$ & 0,0000 \\
\hline Panel PP & $-3,52$ & 0,0002 & $\mathrm{~L}^{*}$ & $-4,90$ & 0,0000 \\
\hline Panel ADF & $-2,87$ & 0,0020 & ed Pm & 5,39 & 0,0000 \\
\hline Group rho & 5,57 & 1,0000 & & & \\
\hline Group PP & $-3,99$ & 0,0000 & & & \\
\hline Group ADF & $-3,09$ & 0,0010 & & & \\
\hline \multicolumn{6}{|c|}{ Relação entre investimento, retorno esperado do capital, preço relativo do capital, taxa de juros e taxa de câmbio } \\
\hline Panel v & $-1,59$ & 0,9438 & $P$ & 118,53 & 0,0000 \\
\hline Panel rho & 3,79 & 0,9999 & Z & $-4,50$ & 0,0000 \\
\hline Panel PP & $-2,95$ & 0,0016 & $L^{*}$ & $-4,61$ & 0,0000 \\
\hline Panel ADF & $-2,19$ & 0,0143 & ed Pm & 5,08 & 0,0000 \\
\hline Group rho & 5,94 & 1,0000 & & & \\
\hline Group PP & $-4,28$ & 0,0000 & & & \\
\hline Group ADF & $-2,57$ & 0,0051 & & & \\
\hline
\end{tabular}

Fonte: Cálculos próprios. Notas: Tanto no caso do teste de Kao quanto no de Pedroni foi usada 1 defasagem em todos modelos, selecionados pelo critério da significância da maior defasagem e pelo critério de informação de Schwarz, respectivamente. Em todos os testes o modelo incluiu constante.

A Tabela 7.7 traz os resultados da estimação de longo prazo para os três modelos. No primeiro modelo, observou-se uma relação negativa, elevada (em módulo) e bastante significativa entre investimento e taxa de juros de longo prazo. Um aumento de 
1 ponto percentual na taxa nominal de juros de longo prazo diminui em 11,95\% o investimento na média dos setores de atividade. A inclusão dessa variável diminuiu de forma expressiva o efeito da oferta de crédito no investimento - o coeficiente associado ao crédito caiu de 0,1640 (Tabela 7.5) para 0,0413. Os coeficientes associados às demais variáveis também variaram consideravelmente.

Tabela 7.7. Relação de longo prazo, DOLS

\begin{tabular}{|c|c|c|c|c|}
\hline & Coeficiente & Erro padrão & Z & p-valor \\
\hline \multicolumn{5}{|c|}{ Relação entre investimento, retorno do capital, preço relativo do capital e taxa de juros } \\
\hline Crédito (In) & 0,0413 & 0,0181 & 2,2900 & 0,0220 \\
\hline Retorno do capital & 0,2010 & 0,0573 & 3,5100 & 0,0000 \\
\hline Preço relativo do capital & $-0,5505$ & 0,1013 & $-5,4300$ & 0,0000 \\
\hline Taxa de juros de longo prazo & $-11,9516$ & 0,3140 & $-38,0700$ & 0,0000 \\
\hline $\mathrm{R}^{2}$ ajustado & 0,8701 & & & \\
\hline Número de observações: & 403 & & & \\
\hline \multicolumn{5}{|c|}{ Relação entre investimento, retorno do capital, preço relativo do capital, taxa de juros e taxa de câmbio } \\
\hline Crédito (In) & 0,0276 & 0,0127 & 2,1800 & 0,0290 \\
\hline Retorno do capital & 0,2161 & 0,0398 & 5,4300 & 0,0000 \\
\hline Preço relativo do capital & $-0,3823$ & 0,0754 & $-5,0700$ & 0,0000 \\
\hline Taxa de juros de longo prazo & $-10,2593$ & 0,2331 & $-44,0200$ & 0,0000 \\
\hline Taxa real de câmbio & 0,3101 & 0,0447 & 6,9400 & 0,0000 \\
\hline $\mathrm{R}^{2}$ ajustado & 0,8893 & & & \\
\hline Número de observações: & 403 & & & \\
\hline \multicolumn{5}{|c|}{ Relação entre investimento, retorno esperado do capital, preço relativo do capital, taxa de juros e taxa de câmbio } \\
\hline Crédito (In) & 0,0263 & 0,0132 & 2,0000 & 0,0460 \\
\hline Retorno esperado do capital & 0,7674 & 0,1259 & 6,0900 & 0,0000 \\
\hline Preço relativo do capital & $-0,4252$ & 0,0755 & $-5,6300$ & 0,0000 \\
\hline Taxa de juros de longo prazo & $-10,9805$ & 0,2499 & $-43,9500$ & 0,0000 \\
\hline Taxa real de câmbio & 0,3048 & 0,0461 & 6,6200 & 0,0000 \\
\hline $\mathrm{R}^{2}$ ajustado & 0,8819 & & & \\
\hline Número de observações: & 403 & & & \\
\hline
\end{tabular}

Fonte: Cálculos próprios. Nota: inclui uma constante por setor de atividade.

No segundo modelo, o coeficiente associado à taxa real de câmbio é positivo, como esperado, e estatisticamente significativo. Como essa taxa é medida em dólares por reais, uma valorização da moeda nacional frente ao dólar norte-americano aumenta a taxa de câmbio em US\$ por R\$, elevando, assim, o investimento. O coeficiente associado ao crédito diminuiu, mas ainda apresentou-se significativo a 5\%. Observa-se que, no último modelo, a substituição do retorno efetivo pelo retorno esperado do capital provoca mudanças nos coeficientes estimados. O coeficiente associado ao crédito é ligeiramente menor e o coeficiente associado ao preço relativo do capital é ligeiramente maior (em módulo) do que os apresentados no modelo anterior. Já o coeficiente associado ao retorno esperado do capital é estatisticamente significativo e bem maior que os das estimativas anteriores.

Esses resultados estão linha com o que foi apresentado no Capítulo 3, muito embora haja diferenças de magnitude dos coeficientes. Eles também servem para relativi- 
zar os resultados do Capítulo 6, os quais indicavam uma influência muito forte da oferta de crédito. Ao se introduzir a taxa de juros de longo prazo nos modelos, as estimativas desta seção mostraram uma queda grande nos coeficientes associados à oferta de crédito sobre o investimento. Isso indica que, no caso brasileiro, um aumento da oferta de crédito só tem efeito expressivo sobre o investimento se ele vier acompanhado de uma redução da taxa de juros de longo prazo. Esse aspecto reforça a importância das mudanças institucionais ocorridas no Brasil que possibilitaram a redução do risco de crédito, com redução das taxas de juros de empréstimos de longo prazo e efeitos positivos sobre a oferta de crédito, como foram os casos da alienação fiduciária, da reforma das Sociedades Anônimas da, Lei do incontroverso e da Lei das falências.

\subsection{Efeitos dos determinantes do investimento na acumulação de capital e no crescimento econômico}

As equações (2.23) a (2.28) do Capítulo 2 definiram a contabilidade do crescimento, a função investimento e os efeitos parciais das variáveis determinantes do investimento sobre a evolução no tempo das taxas de acumulação de capital e de crescimento econômico de uma economia. Com base nessas equações, a Tabela 7.8 traz a decomposição do crescimento econômico dos 31 setores de atividade econômica entre 1995 e $2009 .^{77}$

Os dados da Tabela 7.8 mostram que o crescimento econômico brasileiro entre 1995 e 2009 foi fortemente impulsionado pela acumulação de capital, período no qual ela respondeu por $64 \%$ da taxa de crescimento anual do PIB - o PIB cresceu $2,9 \%$ ao ano e o estoque de capital cresceu 1,8\% ao ano. Esse crescimento, entretanto, não foi igualmente distribuído entre os diversos setores de atividade da economia brasileira. Há setores que cresceram muito acima da média e outros que tiveram queda no valor adicionado como, por exemplo, os setores de transporte aquaviário e aéreo. Os setores de telecomunicações e equipamentos de transportes, por outro lado, foram os que apresentaram as maiores taxas de crescimento do PIB, de 6,3\% ao ano e 5,2\% ao ano, respectivamente.

O setor de equipamentos de transportes teve seu crescimento devido à acumulação de capital e ao crescimento da força de trabalho e teve perda de produtividade nesse período (-0,56\% ao ano). A maioria dos setores industriais também apresentou esse padrão - contri-

\footnotetext{
${ }^{77}$ Vale destacar que esses números não são diretamente comparáveis aos apresentados no Capítulo 6 por se tratar de subperíodos e base de dados distintos. Além disso, a estimação dos números desta seção foi feita com base no retorno efetivo do capital e nas participações efetivas do estoque de capital e da força de trabalho na renda - no Capítulo 6, esses parâmetros foram estimados por meio da fronteira estocástica apresentada no Anexo 6.1.
} 
buição positiva e elevada da acumulação de capital no crescimento e contribuição negativa da evolução da produtividade - com exceção dos setores de madeira, química, farmoquímica e farmacêutica e móveis e produtos diversos. Entre os setores de serviços, o crescimento foi explicado pelo aumento da produtividade - atividades financeiras e de seguro, em que a contribuição da acumulação de capital foi inclusive negativa. Houve, contudo, alguns setores que tiveram elevada contribuição da acumulação do capital para o crescimento: construção, alojamento e alimentação, atividades imobiliárias, saúde e serviços sociais e arte e cultura.

Tabela 7.8. Decomposição do crescimento do PIB por setor de atividade, Brasil, 1995 a 2009 (\% ao ano)

\begin{tabular}{|c|c|c|c|c|}
\hline Setor & $g_{Y}$ & $g_{A}$ & $s_{K} \cdot g_{K}$ & $s_{N} \cdot g_{N}$ \\
\hline Agropecuária & $3,56 \%$ & $-0,18 \%$ & $4,09 \%$ & $-0,35 \%$ \\
\hline Indústria Extrativa & $3,94 \%$ & $-10,19 \%$ & $13,84 \%$ & $0,29 \%$ \\
\hline Produtos Alimentícios, bebidas e fumo & $2,09 \%$ & $-2,40 \%$ & $3,01 \%$ & $1,48 \%$ \\
\hline Têxtil, confec., vestuário e acessórios & $-0,54 \%$ & $-1,56 \%$ & $0,49 \%$ & $0,53 \%$ \\
\hline Couro, artefato e calçado & $-1,98 \%$ & $-5,11 \%$ & $1,56 \%$ & $1,57 \%$ \\
\hline Madeira & $-1,71 \%$ & $-7,55 \%$ & $5,71 \%$ & $0,13 \%$ \\
\hline Celulose, papel e gráfica & $2,70 \%$ & $-7,26 \%$ & $9,74 \%$ & $0,22 \%$ \\
\hline Coque, petróleo e combustível & $5,70 \%$ & $-10,06 \%$ & $14,69 \%$ & $1,07 \%$ \\
\hline Química, farmoquímico e farmacêutico & $5,61 \%$ & $1,57 \%$ & $3,93 \%$ & $0,11 \%$ \\
\hline Borracha e plástico & $-0,55 \%$ & $-5,40 \%$ & $2,79 \%$ & $2,06 \%$ \\
\hline Mineral não metálico & $1,67 \%$ & $-0,24 \%$ & $0,95 \%$ & $0,97 \%$ \\
\hline Produto de metal e metalurgia & $1,99 \%$ & $-4,18 \%$ & $5,10 \%$ & $1,07 \%$ \\
\hline Máquinas e equipamentos & $3,85 \%$ & $-0,55 \%$ & $1,98 \%$ & $2,41 \%$ \\
\hline Equip. info. eletrônico, ótico, máquinas e aparelho elétrico & $1,59 \%$ & $-1,39 \%$ & $1,31 \%$ & $1,66 \%$ \\
\hline Veículo, reboque, carroceria e outros equip. transporte & $5,20 \%$ & $-0,56 \%$ & $2,78 \%$ & $2,98 \%$ \\
\hline Móveis e produtos diversos & $2,37 \%$ & $0,23 \%$ & $1,52 \%$ & $0,62 \%$ \\
\hline Eletricidade, gás, água, esgoto e lixo & $2,90 \%$ & $-0,07 \%$ & $2,68 \%$ & $0,30 \%$ \\
\hline Construção & $2,03 \%$ & $-1,49 \%$ & $2,02 \%$ & $1,50 \%$ \\
\hline Comércio & $2,51 \%$ & $1,02 \%$ & $-0,03 \%$ & $1,53 \%$ \\
\hline Alojamento e alimentação & $6,30 \%$ & $1,29 \%$ & $3,54 \%$ & $1,47 \%$ \\
\hline Transporte terrestre & $-0,27 \%$ & $-2,53 \%$ & $0,74 \%$ & $1,52 \%$ \\
\hline Transporte aquaviário & $-3,26 \%$ & $-4,91 \%$ & $0,44 \%$ & $1,21 \%$ \\
\hline Transporte aéreo & $-2,85 \%$ & $-3,98 \%$ & $0,30 \%$ & $0,84 \%$ \\
\hline Ativ. Aux. transporte e entrega & $0,11 \%$ & $-2,60 \%$ & $1,10 \%$ & $1,60 \%$ \\
\hline Informação, comunicação e telecomunicações & $6,33 \%$ & $0,50 \%$ & $4,27 \%$ & $1,55 \%$ \\
\hline Ativ. financeira e seguro & $3,93 \%$ & $5,69 \%$ & $-1,94 \%$ & $0,19 \%$ \\
\hline Ativ. Imobil., profissional e adm. & $3,41 \%$ & $1,35 \%$ & $1,15 \%$ & $0,91 \%$ \\
\hline Administração Pública & $2,69 \%$ & $-0,62 \%$ & $0,39 \%$ & $2,92 \%$ \\
\hline Educação & $1,39 \%$ & $-1,48 \%$ & $-0,17 \%$ & $3,04 \%$ \\
\hline Saúde e serv. social & $3,11 \%$ & $-0,97 \%$ & $1,79 \%$ & $2,29 \%$ \\
\hline Artes, cultura etc. ${ }^{*}$ & $2,98 \%$ & $-0,85 \%$ & $1,93 \%$ & $1,90 \%$ \\
\hline Total & $2,90 \%$ & $0,01 \%$ & $1,85 \%$ & $1,05 \%$ \\
\hline
\end{tabular}

Fonte: WIOD. Cálculos próprios. Notas: $\left(^{*}\right)$ Artes, cultura, esporte, outras atividades de serviços, manutenção, reparação e organismos internacionais.

É importante observar, contudo, que o padrão de crescimento foi diferente nos dois subperíodos (1995-2002 e 2002-2009), como indicam os dados das Tabelas A.7.4.1 e A.7.4.2 do Apêndice 7.4. A variação entre os dois subperíodos é apresentada na Tabela 7.9. No agregado, a variação da taxa média anual de crescimento de um período em relação ao 
outro foi de 0,83 ponto percentual, com variação negativa da taxa média de aumento da produtividade (-0,47 ponto percentual) e positiva da taxa média de acumulação de capital ( 0,95 ponto percentual). Os setores de transporte aquaviário, petróleo e coque e telecomunicações tiveram quedas muito acentuadas das taxas médias anuais de crescimento do valor adicionado - variações negativas de mais de 7 pontos percentuais. Essas variações ocorreram devido a fortes quedas nas taxas de aumento da produtividade dos setores do primeiro para o segundo período: variações negativas de mais de 6 pontos percentuais.

Tabela 7.9. Variação das taxas de crescimento por setor de atividade, Brasil, 1995 a 2002 contra 2002 a 2009, pontos percentuais

\begin{tabular}{|c|c|c|c|c|}
\hline Setor & $d g_{Y} / d_{t}$ & $d g_{A} / d_{t}$ & $s_{K} \cdot d g_{K} / d_{t}$ & $\mathrm{~s}_{N} \cdot d g_{N} / d_{t}$ \\
\hline Agropecuária & $-1,14$ p.p. & $-1,70$ p.p. & 0,21 p.p. & 0,36 p.p. \\
\hline Indústria Extrativa & $-0,36$ p.p. & 2,71 p.p. & $-4,01$ p.p. & 0,95 p.p. \\
\hline Produtos Alimentícios, bebidas e fumo & $-1,32$ p.p. & $-3,43$ p.p. & $-0,69$ p.p. & 2,80 p.p. \\
\hline Têxtil, confec., vestuário e acessórios & 0,54 p.p. & $-2,39$ p.p. & 1,19 p.p. & 1,74 p.p. \\
\hline Couro, artefato e calçado & $-2,02$ p.p. & $-1,34$ p.p. & 0,11 p.p. & $-0,79$ p.p. \\
\hline Madeira & $-1,66$ p.p. & 1,38 p.p. & $-2,73$ p.p. & $-0,31$ p.p. \\
\hline Celulose, papel e gráfica & 1,19 p.p. & 3,70 p.p. & $-4,90$ р.p. & 2,39 p.p. \\
\hline Coque, petróleo e combustível & $-7,81$ p.p. & $-6,45$ p.p. & $-5,67$ p.p. & 4,31 p.p. \\
\hline Química, farmoquímico e farmacêutico & $-6,47$ p.p. & $-9,41$ p.p. & 0,66 p.p. & 2,28 p.p. \\
\hline Borracha e plástico & 3,42 p.p. & 1,52 p.p. & $-0,08$ p.p. & 1,98 p.p. \\
\hline Mineral não metálico & 2,63 p.p. & $-0,85$ p.p. & 2,00 p.p. & 1,49 p.p. \\
\hline Produto de metal e metalurgia & $-3,40$ p.p. & $-5,93$ p.p. & 1,29 p.p. & 1,24 p.p. \\
\hline Máquinas e equipamentos & $-0,43$ p.p. & $-4,79$ р.p. & 1,03 p.p. & 3,33 p.p. \\
\hline Equip. info. eletrônico, ótico, máquinas e aparelho elétrico & 1,15 p.p. & $-4,80$ p.p. & 2,68 p.p. & 3,27 p.p. \\
\hline Veículo, reboque, carroceria e outros equip. transporte & $-0,32$ p.p. & $-2,55$ p.p. & $-1,20$ p.p. & 3,43 p.p. \\
\hline Móveis e produtos diversos & $-2,48$ p.p. & $-5,66$ p.p. & 2,16 p.p. & 1,01 p.p. \\
\hline Eletricidade, gás, água, esgoto e lixo & 2,63 p.p. & $-2,11$ p.p. & 3,78 p.p. & 0,95 p.p. \\
\hline Construção & 2,02 p.p. & 2,01 p.p. & $-0,14$ p.p. & 0,14 p.p. \\
\hline Comércio & 3,39 p.p. & 3,07 p.p. & 0,62 p.p. & $-0,30$ p.p. \\
\hline Alojamento e alimentação & $-2,97$ p.p. & 1,30 p.p. & $-3,37$ p.p. & $-0,90$ p.p. \\
\hline Transporte terrestre & $-2,36$ p.p. & $-2,88$ p.p. & 1,94 p.p. & $-1,43$ p.p. \\
\hline Transporte aquaviário & $-8,19$ p.p. & -10,35 p.p. & 1,66 p.p. & 0,51 p.p. \\
\hline Transporte aéreo & $-7,38$ p.p. & $-5,84$ p.p. & 1,11 p.p. & $-2,65$ p.p. \\
\hline Ativ. Aux. transporte e entrega & $-1,61$ p.p. & $-4,38$ p.p. & 2,85 p.p. & $-0,08$ p.p. \\
\hline Informação, comunicação e telecomunicações & $-7,57$ p.p. & $-10,45$ p.p. & 4,78 p.p. & $-1,89$ p.p. \\
\hline Ativ. financeira e seguro & 5,47 p.p. & $-3,01$ p.p. & 7,83 p.p. & 0,64 p.p. \\
\hline Ativ. Imobil., profissional e adm. & 1,59 p.p. & 0,80 p.p. & 0,16 p.p. & 0,64 p.p. \\
\hline Administração Pública & 0,45 p.p. & 0,66 p.p. & 0,31 p.p. & $-0,53$ p.p. \\
\hline Educação & $-1,76$ p.p. & $-2,51$ p.p. & 0,21 p.p. & 0,55 p.p. \\
\hline Saúde e serv. social & 1,45 p.p. & 1,84 p.p. & $-0,91$ p.p. & 0,51 p.p. \\
\hline Artes, cultura etc. ${ }^{*}$ & 1,36 p.p. & $-0,03$ p.p. & 1,65 p.p. & $-0,26$ p.p. \\
\hline Total & 0,83 p.p. & $-0,47$ p.p. & 0,95 p.p. & 0,35 p.p. \\
\hline
\end{tabular}

Fonte: WIOD. Cálculos próprios. Notas: (*) Artes, cultura, esporte, outras atividades de serviços, manutenção, reparação e organismos internacionais.

Em alguns setores, como no têxtil, no mineral não metálico, nos equipamentos eletrônicos e óticos e nas atividades financeiras e de seguro, os aumentos nas taxas de acumulação de capital foram importantes para sustentar variações positivas das taxas médias anuais de crescimento do valor adicionado entre os subperíodos 1995-2002 e 2002-2009. O 
aumento do crédito e a evolução do retorno do capital foram importantes para explicar a variação da acumulação de capital.

A Tabela 7.10 traz os efeitos parciais das variações da taxa de crescimento do crédito, da taxa média de retorno do capital, do preço relativo do capital, da taxa nominal de juros de longo prazo e da taxa real de câmbio - variáveis do modelo econométrico - sobre a variação da taxa de crescimento do estoque de capital, para os 31 setores de atividade, entre os subperíodos 1995-2002 e 2002-2009. Para calcular esses efeitos forma empregadas as estimativas do modelo 2 da Tabela 7.7.

Tabela 7.10. Efeitos parciais das variáveis determinantes do investimento sobre a taxa média anual de acumulação de capital, por setor, Brasil, 1995 a 2002 contra 2002 a 2009, pontos percentuais

\begin{tabular}{|c|c|c|c|c|c|c|}
\hline Setor & Crédito & $\begin{array}{r}\text { Retorno } \\
\text { de capital }\end{array}$ & $\begin{array}{r}\text { Preço } \\
\text { relativo do } \\
\text { capital } \\
\end{array}$ & $\begin{array}{r}\text { Taxa de } \\
\text { juros } \\
\text { nominal } \\
\end{array}$ & $\begin{array}{l}\text { Taxa real } \\
\text { de câmbio }\end{array}$ & Conjunto** \\
\hline Agropecuária & 0,01 p.p. & $-0,09$ p.p. & $-0,05$ p.p. & 6,86 p.p. & $-0,14$ p.p. & 5,66 p.p. \\
\hline Indústria Extrativa & 0,41 p.p. & 0,30 p.p. & 5,08 p.p. & 31,05 p.p. & $-0,34$ p.p. & 31,22 p.p. \\
\hline Produtos Alimentícios, bebidas e fumo & 0,07 p.p. & $-0,20$ p.p. & 0,67 p.p. & 7,31 p.p. & $-0,16$ p.p. & 6,67 p.p. \\
\hline Têxtil, confec., vestuário e acessórios & 0,01 p.p. & $-0,19$ p.p. & 0,04 p.p. & 2,92 p.p. & $-0,10$ p.p. & 2,41 p.p. \\
\hline Couro, artefato e calçado & $-0,02$ p.p. & $-0,01$ p.p. & 1,68 p.p. & 7,97 p.p. & $-0,17$ p.p. & 8,23 p.p. \\
\hline Madeira & 0,04 p.p. & $-0,45$ p.p. & 2,22 p.p. & 14,77 p.p. & $-0,24$ p.p. & 13,64 p.p. \\
\hline Celulose, papel e gráfica & 0,14 p.p. & $-0,22$ p.p. & 3,04 p.p. & 41,93 p.p. & $-0,32$ p.p. & 40,13 p.p. \\
\hline Coque, petróleo e combustível & 1,03 p.p. & $-0,23$ p.p. & 4,94 p.p. & 29,91 p.p. & $-0,37$ p.p. & 29,15 p.p. \\
\hline Química, farmoquímico e farmacêutico & 0,06 p.p. & 0,00 p.p. & 0,39 p.p. & 7,59 p.p. & $-0,18$ p.p. & 6,49 p.p. \\
\hline Borracha e plástico & 0,11 p.p. & $-0,09$ p.p. & 2,43 p.p. & 9,11 p.p. & $-0,19$ p.p. & 9,85 p.p. \\
\hline Mineral não metálico & 0,09 p.p. & 0,08 p.p. & 1,12 p.p. & 3,13 p.p. & $-0,13$ p.p. & 3,71 p.p. \\
\hline Produto de metal e metalurgia & 0,12 p.p. & 0,25 p.p. & 2,88 p.p. & 9,00 p.p. & $-0,21$ p.p. & 9,96 p.p. \\
\hline Máquinas e equipamentos & 0,07 p.p. & 0,20 p.p. & 1,25 p.p. & 6,95 p.p. & $-0,19$ p.p. & 6,85 p.p. \\
\hline Equip. info. eletrônico, ótico, máquinas e aparelho elétrico & 0,08 p.p. & 0,25 p.p. & 1,36 p.p. & 4,10 p.p. & $-0,18$ p.p. & 4,46 p.p. \\
\hline Veículo, reboque, carroceria e outros equip. transporte & 0,01 p.p. & $-0,18$ p.p. & 1,26 p.p. & 19,75 p.p. & $-0,30$ p.p. & 17,12 p.p. \\
\hline Móveis e produtos diversos & 0,05 p.p. & 0,03 p.p. & 0,77 p.p. & 3,54 p.p. & $-0,13$ p.p. & 3,58 p.p. \\
\hline Eletricidade, gás, água, esgoto e lixo & 0,03 p.p. & 0,54 p.p. & 1,54 p.p. & 3,30 p.p. & $-0,13$ p.p. & 4,48 p.p. \\
\hline Construção & 0,09 p.p. & $-0,66$ p.p. & $-0,17$ p.p. & 5,16 p.p. & $-0,12$ p.p. & 3,85 p.p. \\
\hline Comércio & 0,03 p.p. & 0,09 p.p. & 0,29 p.p. & 2,05 p.p. & $-0,06$ p.p. & 2,37 p.p. \\
\hline Alojamento e alimentação & 0,00 p.p. & $-0,61$ p.p. & $-1,64$ p.p. & 10,06 p.p. & $-0,13$ p.p. & 6,96 p.p. \\
\hline Transporte terrestre & 0,12 p.p. & 0,12 p.p. & 1,53 p.p. & 2,67 p.p. & $-0,12$ p.p. & 3,80 p.p. \\
\hline Transporte aquaviário & 0,04 p.p. & $-0,06$ p.p. & 1,14 p.p. & 2,67 p.p. & $-0,09$ p.p. & 3,54 p.p. \\
\hline Transporte aéreo & 0,23 p.p. & 0,00 p.p. & 1,16 p.p. & 2,67 p.p. & $-0,09$ p.p. & 3,79 p.p. \\
\hline Ativ. Aux. transporte e entrega & 0,10 p.p. & 0,19 p.p. & 1,60 p.p. & 2,67 p.p. & $-0,12$ p.p. & 3,84 p.p. \\
\hline Informação, comunicação e telecomunicações & 0,20 p.p. & 4,80 p.p. & 2,08 p.p. & 8,98 p.p. & $-0,28$ p.p. & 13,16 p.p. \\
\hline Ativ. financeira e seguro & 0,08 p.p. & 9,34 p.p. & 2,57 p.p. & 1,11 p.p. & $-0,18$ p.p. & 12,23 p.p. \\
\hline Ativ. Imobil., profissional e adm. & 0,03 p.p. & $-0,01$ p.p. & $-0,20$ p.p. & 1,53 p.p. & $-0,04$ p.p. & 1,26 p.p. \\
\hline Administração Pública & 0,13 p.p. & 0,02 p.p. & 0,66 p.p. & 2,84 p.p. & $-0,08$ p.p. & 3,26 p.p. \\
\hline Educação & 0,00 p.p. & 0,08 p.p. & 0,30 p.p. & 0,47 p.p. & $-0,03$ p.p. & 0,85 p.p. \\
\hline Saúde e serv. social & 0,02 p.p. & $-0,72$ p.p. & $-0,51$ p.p. & 9,52 p.p. & $-0,17$ p.p. & 7,27 p.p. \\
\hline Artes, cultura etc. ${ }^{*}$ & 0,10 p.p. & 0,00 p.p. & 0,95 p.p. & 6,53 p.p. & $-0,22$ p.p. & 5,60 p.p. \\
\hline Total & 0,05 p.p. & $-0,07$ p.p. & $-0,03$ p.p. & 4,16 p.p. & $-0,09$ p.p. & 3,59 p.p. \\
\hline
\end{tabular}

Fonte: WIOD, BNDES e Banco Central do Brasil. Cálculos próprios. Notas: (*) Artes, cultura, esporte, outras atividades de serviços, manutenção, reparação e organismos internacionais. (**) Inclui o segundo elemento da equação (2.28).

Em primeiro lugar, nota-se que os efeitos parciais da evolução do crédito e da taxa de juros de longo prazo foram positivos, com exceção do setor de couro no caso do crédito. 
Ou seja, a elevação do crédito e a queda da taxa de juros apontaram para um aumento na taxa de acumulação de capital entre os dois subperíodos. Isso ocorreu porque houve uma expansão do crédito de 19,4\% ao ano entre 1995 e 2009 e uma redução da taxa média anual de juros, que passou de $13,1 \%$ na média entre 1995 e 2002 para $8,5 \%$ na média entre 2002 e 2009.

Os efeitos parciais do retorno do capital e do preço relativo do capital sob a taxa de acumulação de capital foram negativos para a média da economia, mas nem todos os setores seguiram esse padrão. No caso do retorno do capital, a maioria dos setores tiveram efeitos positivos e alguns muito elevados, como os setores de atividades financeiras e telecomunicações, por exemplo. ${ }^{78}$ Como houve desvalorização real do câmbio, que na comparação das médias dos dois subperíodos equivale a uma queda da taxa de câmbio em US\$/R \$, e dado que o coeficiente estimado do câmbio é positivo (Tabela 7.7), o efeito da evolução do câmbio reduziu a taxa de acumulação de capital entre os dois subperíodos. O efeito conjunto das evoluções das quatro variáveis sobre a taxa média anual de acumulação foi positivo, como mostra a última coluna da Tabela 7.10.

A Tabela 7.11 traz a comparação entre a variação observada nas taxas de acumulação de capital entre os dois subperíodos e os efeitos conjuntos sobre a variação da taxa de acumulação de capital do crescimento do crédito e das variações nas taxas médias de retorno do capital, preço relativo, taxa de juros de longo prazo e taxa real de câmbio. No geral, a evolução dessas quatro variáveis indicam os sinais e as magnitudes das variações nas taxas de acumulação de capital entre os subperíodos 1995-2002 e 2002-2009. A Tabela A.7.4.3 do Apêndice 7.4 traz esses efeitos sobre a variação da taxa de crescimento econômico.

No agregado da economia brasileira, foi observado um aumento da taxa média anual de acumulação de capital de 3,94 pontos percentuais entre os dois subperíodos, sendo que as equações de contabilidade do crescimento apontam para uma variação esperada muito próxima, de 3,59 pontos percentuais. Contudo, há setores em que os valores esperados estão muito distantes dos observado. As maiores diferenças entre as variações observadas e previstas pelo modelo ocorreram nos setores de papel e celulose, indústria extrativa, petróleo e veículos e outros equipamentos de transportes. Nesses setores ocorreram desacelerações das taxas de acumulação de capital enquanto que o modelo projetou aumento das taxas de acumulação.

\footnotetext{
${ }^{78}$ Vale observar, contudo, que as estimativas de retorno do capital desses setores feitas pelo WIOD parecem um pouco elevadas, como observado anteriormente.
} 
Tabela 7.11. Variações observadas e esperadas na taxa de acumulação de capital, por setor, Brasil, 1995 a 2002 contra 2002 a 2009, pontos percentuais

\begin{tabular}{|c|c|c|c|}
\hline Setor & Esperado & Observado & Diferença \\
\hline Agropecuária & 5,66 p.p. & 0,06 p.p. & 5,60 p.p. \\
\hline Indústria Extrativa & 31,22 p.p. & $-8,76$ p.p. & 39,98 p.p. \\
\hline Produtos Alimentícios, bebidas e fumo & 6,67 p.p. & 0,52 p.p. & 6,14 p.p. \\
\hline Têxtil, confec., vestuário e acessórios & 2,41 p.p. & 3,24 p.p. & $-0,83$ p.p. \\
\hline Couro, artefato e calçado & 8,23 p.p. & 0,39 p.p. & 7,84 p.p. \\
\hline Madeira & 13,64 p.p. & $-2,40$ p.p. & 16,05 p.p. \\
\hline Celulose, papel e gráfica & 40,13 p.p. & $-14,13$ p.p. & 54,26 p.p. \\
\hline Coque, petróleo e combustível & 29,15 p.p. & $-6,90$ p.p. & 36,05 p.p. \\
\hline Química, farmoquímico e farmacêutico & 6,49 p.p. & 1,42 p.p. & 5,07 p.p. \\
\hline Borracha e plástico & 9,85 p.p. & 0,25 p.p. & 9,61 p.p. \\
\hline Mineral não metálico & 3,71 p.p. & 4,91 p.p. & $-1,21$ p.p. \\
\hline Produto de metal e metalurgia & 9,96 p.p. & 1,46 p.p. & 8,50 p.p. \\
\hline Máquinas e equipamentos & 6,85 p.p. & 2,94 p.p. & 3,91 p.p. \\
\hline Equip. info. eletrônico, ótico, máquinas e aparelho elétrico & 4,46 p.p. & 6,64 p.p. & $-2,18$ p.p. \\
\hline Veículo, reboque, carroceria e outros equip. transporte & 17,12 p.p. & $-3,82$ p.p. & 20,94 p.p. \\
\hline Móveis e produtos diversos & 3,58 p.p. & 4,56 p.p. & $-0,98$ p.p. \\
\hline Eletricidade, gás, água, esgoto e lixo & 4,48 p.p. & 4,62 p.p. & $-0,14$ p.p. \\
\hline Construção & 3,85 p.p. & 0,64 p.p. & 3,21 p.p. \\
\hline Comércio & 2,37 p.p. & 1,45 p.p. & 0,93 p.p. \\
\hline Alojamento e alimentação & 6,96 p.p. & $-4,40$ p.p. & 11,37 p.p. \\
\hline Transporte terrestre & 3,80 p.p. & 5,22 p.p. & $-1,43$ p.p. \\
\hline Transporte aquaviário & 3,54 p.p. & 2,75 p.p. & 0,79 p.p. \\
\hline Transporte aéreo & 3,79 p.p. & 2,86 p.p. & 0,92 p.p. \\
\hline Ativ. Aux. transporte e entrega & 3,84 p.p. & 5,61 p.p. & $-1,76$ p.p. \\
\hline Informação, comunicação e telecomunicações & 13,16 p.p. & 5,33 p.p. & 7,83 p.p. \\
\hline Ativ. financeira e seguro & 12,23 p.p. & 14,45 p.p. & $-2,22$ p.p. \\
\hline Ativ. Imobil., profissional e adm. & 1,26 p.p. & 0,33 p.p. & 0,93 p.p. \\
\hline Administração Pública & 3,26 p.p. & 1,92 p.p. & 1,34 p.p. \\
\hline Educação & 0,85 p.p. & 2,52 p.p. & $-1,67$ p.p. \\
\hline Saúde e serv. social & 7,27 p.p. & $-1,66$ p.p. & 8,93 p.p. \\
\hline Artes, cultura etc. ${ }^{*}$ & 5,60 p.p. & 5,12 p.p. & 0,48 p.p. \\
\hline Total & 3,59 p.p. & 3,94 p.p. & $-0,35$ p.p. \\
\hline
\end{tabular}

Fonte: WIOD, BNDES e Banco Central do Brasil. Cálculos próprios. Notas: $\left(^{*}\right)$ Artes, cultura, esporte, outras atividades de serviços, manutenção, reparação e organismos internacionais.

Isso pode ser decorrência de um elevado crescimento do estoque de capital no primeiro subperíodo (entre 1995 e 2002). No caso do setor de papel e celulose, o estoque de capital cresceu à taxa de 28,3\% ao ano entre 1995 e 2002. Entre 2002 e 2009, a taxa de acumulação caiu para 14,1\% ao ano. A queda no ritmo de acumulação de capital nesses setores também pode ser decorrência da forte crise econômica internacional que ocorreu ao final de 2008, a qual derrubou os preços de commodities, com impactos sobre vários setores - a indústria extrativa, o setor de petróleo e o de celulose -, e provocou forte desvalorização cambial, com efeitos financeiros severos nos setores de minério de ferro e celulose. 


\section{Conclusão}

Ao longo desta tese, vários aspectos da formação de capital foram abordados dos pontos de vista teóricos, econométricos e históricos. Na conclusão desta tese, cabe a reunião desses pontos numa visão perspectiva do desenvolvimento nacional.

A literatura macroeconômica explora um conjunto amplo de variáveis que afetam os investimentos: o retorno dos empreendimentos, a taxa de juros de empréstimo, o preço dos ativos e a oferta de crédito. Esse conjunto de variáveis é bastante relevante para explicar a evolução do investimento, mas não é suficiente para uma interpretação extensa do fenômeno em economias reais. As visões teóricas analisadas partem da pressuposição de que os retornos do capital de diferentes economias são determinados tão-somente pelas produtividades marginais do capital, as quais são dadas pelas condições tecnológicas e pelas disponibilidades de fatores. Desconsidera-se a possibilidade de ineficiências e a existência de custos que venham a interferir na remuneração dos fatores e, assim, provocar diferenças no investimento.

De outro lado, os modelos definem mercados de crédito competitivos com informação perfeita. Mesmo na conceituação de Stiglitz e Weiss (1981), onde os bancos maximizam seus lucros e utilizam a taxa de juros e a exigência de colateral para selecionar projetos de investimento, não há considerações sobre os custos de recuperação do colateral, os quais podem ser distintos em diferentes sociedades. Tampouco se considera que o risco de inadimplência é delineado por regras que variam muito entre países e ao longo do tempo.

Nesse sentido, uma contribuição desta tese foi desenvolver um modelo que incorpora alguns elementos das teorias institucionais entre os fatores determinantes do investimento. Nessa visão, as instituições influenciam o retorno do capital dos empreendedores e dos credores da economia. Ao interferir no retorno do capital dos empreendimentos, as instituições - e, portanto, as mudanças institucionais - têm efeito sobre a acumulação de capital. Ao afetar o retorno dos bancos, as instituições interferem no equilíbrio do mercado de crédito, possibilitando o surgimento de diferentes níveis de oferta de fundos para as mesmas condições macroeconômicas. Essa análise é particularmente importante para entender o desenvolvimento brasileiro.

As relações teóricas foram avaliadas numa amostra de 39 economias com informações anuais entre 1995 e 2011. A abordagem da análise econométrica desenvolvida foi distinta das formulações empregadas na literatura empírica sobre o tema. Em primei- 
ro lugar, vale lembrar que a escolha das variáveis relevantes para o modelo foi baseada direta e exclusivamente no modelo teórico. Esse tipo de abordagem, conforme destacado por Hoover (2007), segue a ideia de Haavelmo (1944) de que os modelos teóricos definidos a priori têm um peso muito importante no desenho da especificação econométrica. O posicionamento adotado nesta tese, como discutido no Capítulo 3, não configurou uma defesa metodológica dessa abordagem, mas sim uma opção que foi suficiente para os objetivos desta tese: medir a relação entre crédito e investimento, levando em consideração outros fatores que também afetam a formação de capital.

A segunda diferença residiu no fato de que não foi incorporado nenhum indicador institucional no conjunto de variáveis explicativas do investimento. A não inclusão de variáveis institucionais na modelagem econométrica foi baseada em quatro observações importantes: (i) não é necessário incluir um indicador institucional no conjunto de variáveis explicativas para avaliar o efeito das mudanças sobre o investimento, pois as informações de uma mudança institucional relevante já estão contidas em outras variáveis consideradas no modelo; (ii) as métricas de mudança institucional têm um grau elevado de arbitrariedade em sua construção; (iii) o uso de indicadores é limitado por suas características estatísticas - variáveis binárias, truncadas e descontínuas; e (iv) em painéis macroeconômicos, as variáveis institucionais relevantes tendem a ter pouca variação no tempo e grande variação entre indivíduos, o que as confunde com o próprio conceito de efeito específico.

As estimativas feitas com base no painel internacional corroboraram a validade das relações teóricas. Os dados sugeriram a ocorrência de relações estáveis e positivas entre investimento, de um lado, e crédito e retorno do capital, de outro. Também foram identificadas relações negativas entre investimento, preço relativo do capital e taxa de juros de longo prazo. É importante observar que, além de contribuir para a validação das relações teóricas, a abordagem econométrica empreendida criou uma referência para a discussão empírica do caso brasileiro.

A avaliação econométrica criou uma base de inferência para a mensuração dos efeitos dos fatores determinantes do investimento na acumulação de capital e no crescimento econômico entre os subperíodos de 1995-2003 e 2003-2011. Essa análise identificou que o balanço da evolução do crédito, do retorno do capital e do preço relativo do capital afetou positivamente a maior parte dos países analisados, sendo que na média da amostra pode ser atribuída aos determinantes do investimento uma contribuição de 1,26 ponto percentual na variação da taxa de acumulação de capital entre os dois subperío- 
dos. Para a maior parte dos países, a evolução dos determinantes do investimento teve impacto positivo na variação das taxas de crescimento econômico entre os dois subperíodos, sendo particularmente elevado em nações em desenvolvimento - China, México, Polônia e Turquia.

A análise histórica do Brasil identificou que o processo de crescimento econômico do país também foi movido a acumulação de capital. A acumulação foi financiada por mecanismos de crédito formados na segunda metade do século XIX e aperfeiçoados nos séculos XX e XXI. O crédito hipotecário, o mercado acionário e os subsídios governamentais se completaram, em diferentes proporções, ao longo da história econômica brasileira.

Nos anos 1950, a criação do BNDE deu novos rumos ao financiamento de longo prazo, assim como as estatais tomaram a frente dos investimentos em algumas áreas estratégicas. As reformas institucionais dos anos 1960 buscaram refundar o financiamento em mecanismos mais modernos de intermediação financeira e os planos de desenvolvimento redirecionaram o investimento. Bem sucedidas no objetivo de alavancar a acumulação de capital, a estrutura de intermediação financeira do país e a estratégia de desenvolvimento foram, contudo, abaladas pelas crises da dívida externa e fiscal e pela hiperinflação. Esses eventos desarticularam o crédito de longo prazo no país e levaram ao encerramento de importantes instituições de fomento, como o BNH, e à estagnação dos investimentos estatais.

As mudanças institucionais ocorridas nas décadas de 1990, 2000 e 2010 foram motivadas e articuladas por grupos de interesse que buscavam recuperar sua condição econômica comprometida com a crise e ampliar suas oportunidades de negócios. Outras mudanças - como a abertura comercial, por exemplo - responderam a uma agenda internacional que colocava como precondições à renegociação da dívida externa de países em desenvolvimento mudanças institucionais de caráter liberal. Em qualquer desses casos, é fundamental entender as mudanças como resultado da articulação política entre grupos que, em momentos sociopolíticos particulares, criou as condições para as transformações. Em algumas situações, as mudanças implantadas geraram as condições suficientes para a retomada do crédito ou do investimento. Em outras, isso não ocorreu. Mas, no geral, todos os setores da economia brasileira foram afetados por alguma mudança institucional no período, o que contribui para entender a grande alteração nos valores e na composição setorial dos investimentos e do crédito. 
Os modelos empíricos desenvolvidos para o caso brasileiro mostraram que, de fato, a evolução do crédito foi importante para o processo de crescimento econômico brasileiro, mas, no período mais recente, a redução dos juros de longo prazo aparece como um dos pontos fundamentais. A estimação das relações entre as variáveis mostrou um efeito muito forte da taxa de juros de longo prazo sobre o investimento. Outro fato importante é que, no modelo com dados setoriais do Brasil, os coeficientes estimados para o crédito diminuíram quando a taxa de juros foi introduzida nas regressões, aos moldes do que havia sido identificado no painel internacional, mas em menor extensão. Isso indica que um aumento da oferta de crédito tem efeito mais expressivo sobre o investimento se ele vier acompanhado de uma redução da taxa de juros de longo prazo, um efeito que parece particularmente forte no caso brasileiro.

Esse aspecto reforça a importância das mudanças institucionais ocorridas no Brasil, as quais possibilitaram a redução do risco de crédito, com diminuição das taxas de juros de empréstimos de longo prazo e efeitos positivos sobre a oferta de crédito. Medidas institucionais dessa natureza foram a criação da figura da alienação fiduciária, a Lei do Incontroverso, a reforma das Sociedades Anônimas e a nova Lei das Falências.

As análises de contabilidade de crescimento mostram que, de fato, as contribuições da evolução do crédito e do retorno do capital foram historicamente relevantes para a taxa de crescimento do estoque de capital. A análise do banco de dados setorial, que incorporou os efeitos da evolução da taxa de juros de longo prazo, destacou o papel fundamental da redução dos juros de longo prazo empreendida desde 2003 sobre o crescimento econômico.

Olhando de forma perspectiva, as análises desenvolvidas nesta tese permitem também enfocar o caminho do crescimento econômico como condicionado ao desenvolvimento institucional. A criação de melhores condições de retorno do capital e a redução do risco dos credores e dos investidores, com melhores condições de governança, são pré-condições para a redução da taxa de juros de longo prazo, do aumento sustentado do crédito e da aceleração da acumulação de capital. Nesse sentido, a consolidação da participação social na governança das instituições figura como condição necessária ao desenvolvimento. 


\section{Referências bibliográficas}

ACOSTA, P. e LOZA, A. Short and long run determinants of private investment in Argentina. Journal of Applied Economic, v. 8, n. 2, p. 389-406, 2005.

AGHION, P. e BOLTON, P. An Incomplete contracts approach to financial contracting. Review of Economic Studies, v. 59, p.473-494, 1992.

ARAUJO, A e FUNCHAL, B. A nova lei de falências brasileira: primeiros impactos. Brazilian Journal of Political Economy, v. 29, n. 3 (115), p.191-212, July-September, 2009.

ARAUJO, J.A., FEITOSA, D.G. e SILVA, A.B. América Latina: productividad total de los factores y su descomposición. Revista de la Cepal, vol. 114. 2014.

ARAUJO, V. L. F. C. Revisitando o desenvolvimento brasileiro: O BNDE e o financiamento de longo prazo - 1952/1964, Tese (Doutorado), Universidade Federal Fluminense, Niterói, 2007.

ARELLANO, M. e BOVER, O. Another look at the instrumental variables estimation of errorcomponent model. Journal of Econometrics, v.68, p. 29-51, 1995.

ASSOCIAÇÃO BRASIELIRA DE TELECOMUNICAÇÕES. O desempenho do setor de Telecon - Séries temporais 2014, Brasília, 2014.

BAI, J. e NG, S. A panic attack on unit roots and cointegration. Econometrica, v.72, p.1127-1177, 2004.

BALTAGI, B. H. Econometric analysis of panel data, John Wiley \& Sons, Ltd, 4a ed., 2008.

BANCO CENTRAL DO BRASIL. Séries Temporais. 2014.

Disponível em: < http://www.bcb.gov.br/pt-br/paginas/default.aspx>.

BANCO DO BRASIL. História do Banco do Brasil. Diretoria de Marketing e Comunicação do Banco do Brasil, Belo Horizonte, $2^{\mathrm{a}}$ edição, 2010.

BANCO DO BRASIL. Relatório anual de 1946, Rio de Janeiro, 1947.

BANDEIRA, A. Reformas econômicas, mudanças institucionais e crescimento na América Latina. Dissertação (Mestrado de Economia de Empresas) Escola de Administração de Empresas de São Paulo, Fundação Getulio Vargas, São Paulo, 2002.

BANERJEE, A., DOLADO, J. J. e MESTRE, R. Error-correction mechanism tests for cointegration in a single-equation framework, Journal of Time Series Analysis, v. 19, p. 267-283, 1998.

BECK, T. G., CLARKE, A., GROFF, P., KEEFER, P. e WALSH, P. New tools and new tests in comparative political economy: the database of political institutions. Mimeo, World Bank, Washington, DC, 1999.

BESKOW, P. R. O crédito rural público numa economia em transformação: estudo histórico e avaliação econômica das atividades de financiamento agropecuário da CREAI/BB, de 1937 a 1965. Tese (Doutorado em Economia) Instituto de Economia, Univesidade de Campinas, 1994.

BLANCHARD, O. Output, the sock markets and interest rate. American Economic Review, v. 71. p. 123-43, 1981.

BLEJER, M. I. e KHAN, M. S. Government policy and private investment in developing countries. IMF Staff Papers, n. 2, 1984.

BREITUNG, J. e DAS, S. Panel unit root tests under cross sectional dependence. Statistica Neerlandica, v. 59, p.414-433, 2005.

BREITUNG, J. The local power of some unit root tests for panel data. In: BALTAGI, B.H. Advance in Econometrics Volume 15: Nonstationary Panels, Panel Cointegration and Dynamics Panels, Amsterdan, JAI Press, p.161-178, 2000. 
CHOI, I. Unit root tests for panel data. Journal of International Money and Finance, v.20, p.249$272,2001$.

CLAGUE, C., KEEFER, P., KNACK, S. e OLSON, M. Contract-intensive money: contract enforcement, property rights, and economic performance. Journal of Economic Growth, v. 4, p.185$211,1999$.

COSTA NETO, Y. C. Bancos oficiais no Brasil: origem e aspecto de seu desenvolvimento. Brasília: Banco Central do Brasil, 2004.

COSTA, F. N. e DEOS, S. S. Reflexões sobre o financiamento na economia brasileira. Texto para Discussão IE/UNICAMP, n. 109, abr. 2002.

CRUZ, B. C. e TEIXEIRA, J. R. The impact of public investment on private investment in Brazil, 1947-1990. Cepal Review 67, April, 1999.

DICKEY, D. A. e PANTULA, S. G. Determining the order of differencing in autoregressive process. Journal of Business and Economic Statistics, v. 15, p. 455-461, 1987.

DICKEY, D. e FULLER, W. A. Distribution of the estimators for autoregressive time series with a unit root. Journal of the American Statistical Association, v. 74, n. 366, p.427-431, 1979.

DICKEY, D. e FULLER, W. A. Likelihood ratio statistic for autoregressive time series with a unit root. Econometrica, v. 49, n. 4, p.1057-1073, 1981.

EDWARDS, S. Crisis and reform in Latin America: from despair to hope. New York: Oxford University Press, 1995.

ENGLE, R. F. e GRANGER, C. Co-integration and error correction: representation, estimation and testing. Econometrica, v. 55, n. 5, 1987.

ERDEN, L. e HOLCOMBE, R. The effects of public investment on private investment in developing economies. Public Finance Review, v. 33, n. 5, p. 575-602, 2005.

EUROPEAN CENTRAL BANK. Statistics. 2014.

Disponível em: < https://www.ecb.europa.eu/stats/html/index.en.html $>$.

FISHER, R.A. Statistical methods for research workers. Oliver and Bond, $4^{\text {th }}$. ed., Edinburgh, 1932.

FRANCO, G. A primeira década republicana. In: ABREU, M. P. A ordem do progresso: cem anos de política econômica republicana, 1889-1989. Editora Campus, 1990.

FREITAS, G. F., MAGNABOSCO, A. L. e CUNHA, P. F. Chile: Subsidies, credit and housing deficit, Cepal Review, v. 110, p. 189-211, agosto de 2013.

GARCIA, F., SOUZA, R. C. e PIRES, J. O. Technical change: it should be positive and make sense! Economics Letters, v. 100, p. 388-391, 2008.

GHATE, C., LE, Q. L. e ZAK, P. J. Optimal fiscal policy in an economy facing sociopolitical instability. Review of Development Economics, v. 7, n.4, p. 583-598, 2003.

GREENE, J. e VILLANUEVA, D. Private investment in developing countries: an empirical analysis. IMF Staff Papers, v. 38, n.1, p. 33-58, março de 1991.

GREGORY, A. e HANSEN, B. Residual-based tests for cointegration in models with regime shifts. Journal of Econometrics, v. 70, p. 99- 126, 1996.

GROEN, J. e KLEIBERGEN, F. Likelihood-based cointegration analysis in panels of vector error correction models, Journal of Business and Economic Statistics, v. 21, p. 295-318, 2003.

HAAVELMO, T. The probability approach in econometrics. Econometrica, v.12, July,1944.

HADRI, K. e LARSSON, R. Testing for stationarity in heterogeneous panel data where the time dimension is fixed. Econometrics Journal, v.8, p.55-69, 2005. 
HADRI, K. Testing for stationarity in heterogeneous panel data. The Econometrics Journal, v. 3, n. 2, p.148-161, December, 2000.

HANLEY, Anne. A bolsa de valores e o financiamento de empresas em São Paulo, 1886-1917. História Econômica \& História de Empresas, v.4, n. 2, p. 115-142, 2001.

HARRIS, R. e TZAVALIS, E. Inference for unit roots in dynamic panels where the time dimension is fixed. Journal of Econometrics, n. 91, p.201-226, 1999.

HART, O e MOORE, J. Incomplete contracts and renegotiation. Econometrica, v. 56, p. 755-786, 1989.

HART, O. Firms, Contracts and Financial structure. Clarendon Press, Oxford, New York, 1995.

HENISZ, W. J. The Institutional environment for economic growth. Economics and Politics, n. 12, p. $1-31,2000$.

HESTON,A., SUMMERS, R. e ATEN, B. Penn World Table Version 7.1, Center for International Comparisons of Production, Income and Prices at the University of Pennsylvania, July, 2012.

HLOUSKOVA, J. e WAGNER, M. The performance of panel unit root and stationarity tests: results from a large scale simulation study. Econometric Reviews, v.25, n.1, p.85-116, 2006.

HOOVER, K. Probability and structure in econometric models, Economics Research Initiatives at Duke (ERID) Working Paper n. 18, setembro de 2007

IDB - Inter-American Development Bank. Economic and social progress in Latin America. Washington, DC. Inter-American Development Bank, 1996.

IM, K., PESARAN, M. H. e SHIN, Y. Testing for unit roots in heterogeneous panels. Journal of Econometrics, n. 115, p. 53-74, 2003.

INSTITUTO BRASILEIRO DE GEOGRAFIA E ESTATÍSTICA. Anuários Estatísticos do Brasil, 1908-1946. Rio de Janeiro, vários anos.

INSTITUTO BRASILEIRO DE GEOGRAFIA E ESTATÍSTICA. Estatísticas Históricas do Brasil. $2^{\text {a }}$ edição revista e atualizada, Rio de Janeiro, 1990.

JOHANSEN, S. Likelihood based inference in cointegrated vector auto-regressive models. Oxford University Press, Oxford, 1995.

JORGENSON, D. W. The Theory of investment behavior, In: Ferber, R. Determinants os investment behavior. UMI, p. 129-88, New York, 1967.

KAO, C. Spurious regression and residual-based tests for cointegration in panel data. Journal of Econometrics, v. 90 p.1-44, 1999.

KAO, C., e CHIANG, M.H. On the estimation and inference of a cointegrated regression in panel data. In: BALTAGI, B.H. Advance in Econometrics Volume 15: Nonstationary Panels, Panel Cointegration and Dynamics Panels, Amsterdan, JAI Press, p.179-222, 2000.

KEYNES, J. M. A. The General Theory of Employment, Interest and Money. San Diego: Harcourt Brace Jovanovich, 1936.

KNELLER, R. e STEVENS, A. The specification of aggregate production function in the presence of inefficiency. Economics Letters, v. 81, p. 223-226, 2003.

KREMERS, J., ERICSSON, N. e DOLADO, J. The power of cointegration tests, Oxford Bulletin of Economics and Statistics, v. 54, p. 325-348, 1992.

KRUEGER, A.O. The political economy of rent seeking. The American Economic Review, v.64, n.3, p.291-303, 1974.

KUGLER, J. e ARBERMAN, M. Relative political capacity: political extraction and political reach. In: ARBETMAN, M. e KUGLER, J. (eds) Political Capacity and Economic Behavior, Westview Press, Colorado, 1997. 
KUMBHAKAR, S. C. e WANG, H. Estimation of growth convergence using a stochastic production frontier approach. Economics Letters, v. 88, p. 300-305, 2005.

KWIATKOWSKI, D., PHILLIPS, P.C.B., SCHMIDT, P. e SHIN, Y. Testing the new hypothesis of stationarity against the alternative of unit root. Journal of Econometrics, v.54, p.159-178. 1992.

LAFER, C. Planejamento Econômico no Brasil, São Paulo: Perspectiva, 1973.

LARSSON, R., LYHAGEN, J. e LOTHGREN, M. Likelihood-based cointegration tests in heterogeneous panels, Econometrics Journal, v. 4, p.109-142, 2001.

LE, Q. V. Political and economic determinants of private investment. Journal of International Development. p. 589-604, 2004.

LEVIN, A. e LIN, C.F. Unit root tests in panel data: asymptotic and finite-sample properties. University of California San Diego, Discussion paper, San Diego, 1993.

LEVIN, A., LIN, C. e CHU, C. J. Unit root tests in panel data: asymptotic and finite-sample properties. Journal of Econometrics, n. 108, p. 1-24, 2002.

LORA, E. A decade of structural reforms in Latin America. Inter-American Development Bank Working Paper, n. 348, Washington, D. C., 1997.

LUPORINI, V. e ALVES, J. Investimento privado: uma análise empírica para o Brasil. Economia e Sociedade, v. 19, n. 3, p. 449-475, Campinas, dezembro de 2010.

MACKINNON, J. G, Critical values for cointegration tests, Chapter 13. In: ENGLE, R. F. e GRANGER, C. W. J. Long-run economic relationships: readings in cointegration, Oxford, Oxford University Press, 1991.

MADDALA, G. S. e WU, S. A comparative study of unit root tests with panel data and a new simple test. Oxford Bulletin of Economics and Statistics, Special Issue, 1999.

MAGNABOSCO, Ana L., A política de subsídios habitacionais e sua influência na dinâmica de investimento imobiliário e no déficit de moradias do Brasil e do Chile, Dissertação (Mestrado em Economia Política), Pontifícia Universidade Católica de São Paulo, 2011.

MANKIW, N. G., ROMER, D. e WEIL, D., A Contribution to the empirics of economic growth, Quarterly Journal of Economics, v. CVII, p. 407-37, 1992.

MARCONDES, R. L. Crédito privado antes da Grande Depressão do século XX: o mercado hipotecário brasileiro. In: XXXI Encontro da associação portuguesa de história económica e social. Coimbra, Portugal, novembro de 2011.

MARTONE, C. L.; LUQUE, C. A. e LOPES, L. M. Mercado financeiro e ajustamento macroeconômico brasileiro: 1978-1985, Instituto de Pesquisas Econômicas, São Paulo, 1986.

MCCOSKEY, S. e KAO, C. A residual-based test of the null of cointegration in panel dat. Econometric Reviews, v.17, n.1, p. 57-84, 1998.

MINISTÉRIO DE MINAS E ENERGIA. Balanço Energético Nacional. Empresa de Pesquisa Energética, Brasília, 2014.

MORANDI, L. Estimativa do estoque de capital fixo no Brasil - 1950/2000. Rio de Janeiro: IPEA / Dimac, 2003.

MORLEY, S.A., MACHADO, R. e PETTINATO, S. Indexes of structural reform in Latin America. Santiago: CEPAL. Série Reformas Econômicas, n. 12, 1999.

MUSACCHIO, Aldo. Experiments in financial democracy: corporate governance and financial development in Brazil, 1882-1950. New York: Cambridge University Press, 2009.

MUTH, R.C. e GOODMAN, A.C. The economics of housing markets, Harwood Academic Publishers, 1989. 
MUTH, R.C. The demand for non-farming housing. In: HARBERGER. The Demand for Durable Goods. The University of Chicago Press, Chicago, 1960.

NORTH, D. C. e WEINGAST, B. R. Constitutions and commitment: the evolution of institutions governing public choice in seventeenth-century England. The Journal of Economic History, v. XLIX, n. 4, December 1989.

NORTH, D. C. Institutions, Institutional change and economic performance. Cambridge University press, 1990.

ORGANIZATION FOR ECONOMIC CO-OPERATION AND DEVELOPMENT. OECDStat.

2014. Disponível em: < http://stats.oecd.org/>.

ORGANSKI, A. e KUGLER, J. The War Ledger. University of Chicago Press, Chicago, 1980.

PEDRONI, P. Critical values for cointegration tests in heterogeneous panels with multiple regressors, Oxford Bulletin of Economics and Statistics, v. 61, p. 653-678, 1999.

PEDRONI, P. Fully Modified OLS for heterogeneous cointegrated panels. In: BALTAGI, B.H. Advance in Econometrics Volume 15: Nonstationary Panels, Panel Cointegration and Dynamics Panels, Amsterdan, JAI Press, p. 93-130, 2000.

PEDRONI, P. Panel cointegration: asymptotic and finite sample properties of pooled time series tests with an application to the PPP hypothesis. Econometric Theory, v. 20, p. 597-625, 2004.

PESARAN M.H. General diagnostic tests for cross section dependence in panels, Cambridge Working Papers in Economics, n.435, University of Cambridge, 2004.

PESARAN, M.H. A simple panel unit root test in the presence of cross-section dependence. Journal of Applied Econometrics, v. 22, p. 265-312, 2007.

PHILLIPS, P.C.B. e SUL, D. Dynamic panel estimation and homogeneity testing under cross section dependence. Econometrics Journal, v.6, p.217-259, 2003.

PIRES, J. e GARCIA, F. (2012). Productivity of Nations: A stochastic frontier approach to TFP decomposition. Economics Research International, v. 2012, Article 584869, Hindawi Publishing Corporation, 2012.

QUINN, D. The correlates of change in international financial regulation. American Political Science Review, v. 91, n. 3, 1997.

RIBEIRO, M. B. e TEIXEIRA, J. R. An econometric analysis of private-sector investment in Brasil. Cepal Review, v. 74, ago de 2001.

ROCHA, C. H. e TEIXEIRA, J. R. Complementariedade versus substituição entre investimento público e privado na economia brasileira: 1965-90, Revista Brasileira de Economia, Rio de Janeiro, v. 50, n. 3 p. 378-384, jul./set. 1996.

RODRIK, D. Who needs capital-account convertibility? In: DORNBUSCH, R. (org). Essays in International Finance, Princeton: Princeton University, 1998

RONCI, M. V. Government policy and private investment in Brazil 1955-82. Tese (Doutorado) Escola de Pós-graduação em Economia. Fundação Getulio Vargas, Rio de Janeiro, jun. 1987.

SAES, Flávio A. M. Crédito e bancos no desenvolvimento da economia paulista:1850-1930. São Paulo: IPE-USP, 1986.

SANT'ANNA A. A., BORÇA, G. J. e ARAUJO, P. Q. Mercado de crédito no Brasil: Evolução recente e o papel do BNDES (2004-2008). Revista do BNDES, v. 16, n.31, Rio de Janeiro, 2009.

SANTANA, J. R. Três ensaios sobre liberalização financeira, movimento de capitais e crescimento econômico. Tese (Doutorado em Economia de Empresas) Escola de Administração de Empresas de São Paulo, Fundação Getulio Vargas, São Paulo, 2004. 
SERVÉN, L. e SOLIMANO, A. Private investment and macroeconomic adjustment: A survey, The World Bank Research Observer, v. 7 n. 1, Washington, D.C., 1992.

SHEFFRIN, S. M. Expectativas racionales. Alianza Universidad, Madrid, 1985.

SILVA, M. F. O controle dos processos de licitação: uma análise de Economia Política, parte1. Estudos Econômicos da Construção, v.2, n.3, p.53-88, 1997a.

SILVA, M. F. O controle dos processos de licitação: uma análise de Economia Política, parte 2. Estudos Econômicos da Construção, v.2, n.4, p.1-16, $1997 \mathrm{~b}$.

SILVA, M. S. Política de mobilização de capitais para investimento privado: regulação bancária, e funding, operacionalização e desempenho da CREAI (1932-1945). Revista Economia, v.8, n.4, p.123-148, Brasília, dezembro de 2007.

SOCHACZEWSKI, A. C. Desenvolvimento econômico e financeiro do Brasil: 1952-1968. Tese (Doutordo) Universidade de Londres, Trajetória Cultural, 1993.

STASAVAGE, D. Private investment and political institutions. Economics and Politics, v. 14, 2002.

STIGLITZ, J. E. e WEISS A. Credit rationing in markets with imperfect information. The American Economic Review, v. 71, n. 3, 1981.

SUZIGAN, W. A indústria brasileira - origem e desenvolvimento. São Paulo: Brasiliense, 1986.

TAVARES, M. C., MELO, H. P., CAPUTO, A., COSTA, G., ARAUJO, V. O Papel do BNDE na industrialização do Brasil: Os anos dourados do desenvolvimentismo, 1952-1980. Memórias do desenvolvimento, v. 4, 2010.

TIMMER, M.P. (ED). The World Input-Output Database (WIOD): Contents, Sources and Methods, WIOD Working Paper, n. 10, 2012.

TIMMER, M.P. (ED). The World Input-Output Database: database. July, 2014.

Disponível em: < http://www.wiod.org/new_site/database/seas.htm $>$

TOBIN, J. A general Equilibrium Approach to Monetary Theory. Journal of Money, Credit and Banking, v. 1, n.1, p.15-29, 1969.

TULLOCK, G. The economics of special privilege and rent seeking. Kluwer Academic Press, 1990.

TULLOCK, G. The welfare costs of tariffs, monopolies and theft. Western Economic Journal, v.5, 1967.

WESTERLUND, J. New simple tests for panel cointegration, Econometric Reviews, v. 24, n.3, p. 297-316, 2005.

WESTERLUND, J. Testing for Error Correction in Panel Data. Oxford Bulletin of Economics and Statistics, v. 69, n. 6, p. 709-748, 2007.

WORLD BANK. World Development Indicators on line. 2014.

Disponível em $<$ http://data.worldbank.org/data-catalog/world-development-indicators $>$.

ZIVOT, E. e ANDREWS, D. W. K. Further evidence on the great crash, the oil-price shock, and the unit-root hypothesis. Journal of Business \& Economic Statistics, v. 20, n. 1, p. 25-44, 2002. 


\section{Apêndices}

\section{Apêndice 3.1 Séries de retorno esperado do capital}

O retorno do capital $(r)$ é um conceito contábil calculado diretamente da contabilidade social dos países e setores de atividade. Ele mede a relação entre a parcela do valor adicionado que é distribuída aos capitalistas e o estoque de capital empregado na produção $(K)$. A renda que cabe ao capital é definida como o produto do valor adicionado $(Y)$ pela parcela do capital na distribuição funcional da renda $\left(S_{K}\right)$ - equação (A.1). Seu valor é conhecido após a aferição das contas sociais e nela estão contidas todas informações relativas a choques de preços ou de demanda.

(A.1) $r=S_{K} \cdot \frac{Y}{K}$.

O retorno esperado do capital, por sua vez, é um conceito teórico que vem da ideia de maximização de lucros. O conceito também é chamado de produtividade marginal do capital e difere do retorno efetivo do capital porque não é uma variável contábil e sim uma medida que pode ser obtida por técnicas econométricas. A construção desse conceito e de sua medida empírica segue o raciocínio de otimização dos lucros das firmas exposto na equação (A.2), em que $P$ é o lucro, $Y$ é a produção, $w$ é o salário médio, $N$ é o número de trabalhadores, $r$ é o retorno esperado do capital e $K$ é o estoque de capital.

(A.2) $\quad \operatorname{Max} P=Y-w . N-r^{e} . K$

De acordo com a condição de primeira ordem, o retorno esperado do capital é igual à produtividade marginal do capital. A condição de primeira ordem é dada por:

$$
\frac{\partial P}{\partial K}=\frac{\partial Y}{\partial K}-r^{e}=0 \quad \rightarrow \quad \frac{\partial Y}{\partial K}=r^{e} .
$$

A estimativa da produtividade marginal do capital empregada na seção 3.3 foi obtida a partir de uma modelo econométrico que estimou a elasticidade do capital para uma função de produção. A estimativa da elasticidade do produto em relação ao capital foi obtida pelo modelo de fronteira estocástica descrito na equação (A.3):

(A.3) $Y=f(t, K, N, \beta) \cdot \exp (v) \cdot \exp (-u), i=1, \ldots, n ; t=1, \ldots, T$.

em que $y$ é o logaritmo natural do PIB, $i$ representa o país, $t$ o período, $K$ e $N$ são os fatores de produção; $v$ e $u$ são dois componentes não observados - o primeiro refere-se ao erro aleatório e o segundo $(u)$ é o desvio para baixo da fronteira de produção que mede a ineficiência técnica. A estimativa da ineficiência $u$ pressupõe que essa variável é positiva e tem uma distribuição nor- 
mal truncada em 0 . A média de $u$ é condicionada ao período $t$ e ao número de horas trabalhadas por empregado em cada país.

Com base na fronteira de produção é possível estimar a elasticidade do PIB em relação ao capital $\left(\varepsilon_{K}\right)$, a qual é definida pela equação (A.4). Passando $Y$ e $K$ para o outro lado da equação (A.4), chega-se à expressão (A.4'), que define a produtividade marginal do capital como o produto da elasticidade pela relação produto-capital de cada economia.

(A.4) $\varepsilon_{K}=\frac{\partial Y}{\partial K} \cdot \frac{K}{Y}$ e (A.4') $\frac{\partial Y}{\partial K}=\varepsilon_{K} \cdot \frac{Y}{K}$.

Vale destacar, que apenas por coincidência a produtividade marginal do capital é igual ao retorno efetivo do capital. Isso ocorre somente quando a participação do capital na distribuição funcional da renda é idêntica à elasticidade do PIB ao capital: $\varepsilon_{K}=S_{K}$.

O modelo de fronteira estocástica foi estimado para uma amostra de 39 países entre 1995 e 2011. Os dados foram obtidos no World Input-Output Database (WIOD), no World Development Indicators on line, do Banco Mundial (WDI) e na base de dados da OCDE Statistics (OECDStat). Os países da amostra são: Austrália, Áustria, Bélgica, Brasil, Bulgária, Canadá, China, Chipre, República Checa, Dinamarca, Estônia, Finlândia, França, Alemanha, Grécia, Hungria, Índia, Indonésia, Irlanda, Itália, Japão, República da Coréia, Látvia, Lituânia, Luxemburgo, Malta, México, Holanda, Polônia, Portugal, Romênia, Rússia, Eslováquia, Eslovênia, Espanha, Suécia, Turquia, Reino Unido, Estados Unidos. As variáveis empregadas são:

- PIB: corresponde ao Produto Interno Bruto em dólares constantes de 1995. A variável foi transformada em logaritmo natural (ln). A fonte é o WIOD.

- Estoque de capital: corresponde ao estoque de capital dos países em US\$ constantes de 1995. Alguns países não dispunham de informações sobre o estoque de capital fixo para os anos de 2008 a 2011. Nesses casos, foi utilizado o a técnica do inventário perpétuo para calcular o estoque de capital, que consiste na soma do estoque de capital fixo do ano anterior, descontada a depreciação (de 5\%), com a média do investimento em $t$ e $t-1$. O investimento foi obtido no WDI e na base OECDStat. A variável também foi transformada em $\ln ^{79}$

- Força de trabalho: corresponde a população com 15 anos de idade ou mais que oferta trabalho. Inclui empregados e desempregados. Em geral, inclui as pessoas que trabalham nas forças armadas e exclui trabalhadores domésticos e não remunerados. Essa variável também foi transformada em $l n$. A fonte é o WIOD.

\footnotetext{
${ }^{79}$ Todos os países tiveram estoque de capital fixo calculado dessa forma nos anos de 2010 e 2011 . Alguns países não dispunham de informações também para os anos de 2008 e 2009, são eles: Áustria, Chipre (somente 2009), República Tcheca, Alemanha, Dinamarca, Espanha, Finlândia, França, Inglaterra, Hungria, Irlanda, Itália, Holanda, Polônia, Portugal (somente 2009) e Suécia.
} 
- Horas trabalhadas: corresponde ao número de horas trabalhadas em cada economia. A fonte é o WIOD.

O resultado da estimação da fronteira estocástica para esse painel é apresentado na Tabela A.3.3.1. Apesar do fato de que nem todos coeficientes são significativos a 5\%, as estimativas de $\varepsilon_{K}$ resultaram em valores próximos ao do retorno efetivo do capital para a maior parte dos países e períodos da amostra.

Tabela A.3.3.1 Resultados da Fronteira Estocástica

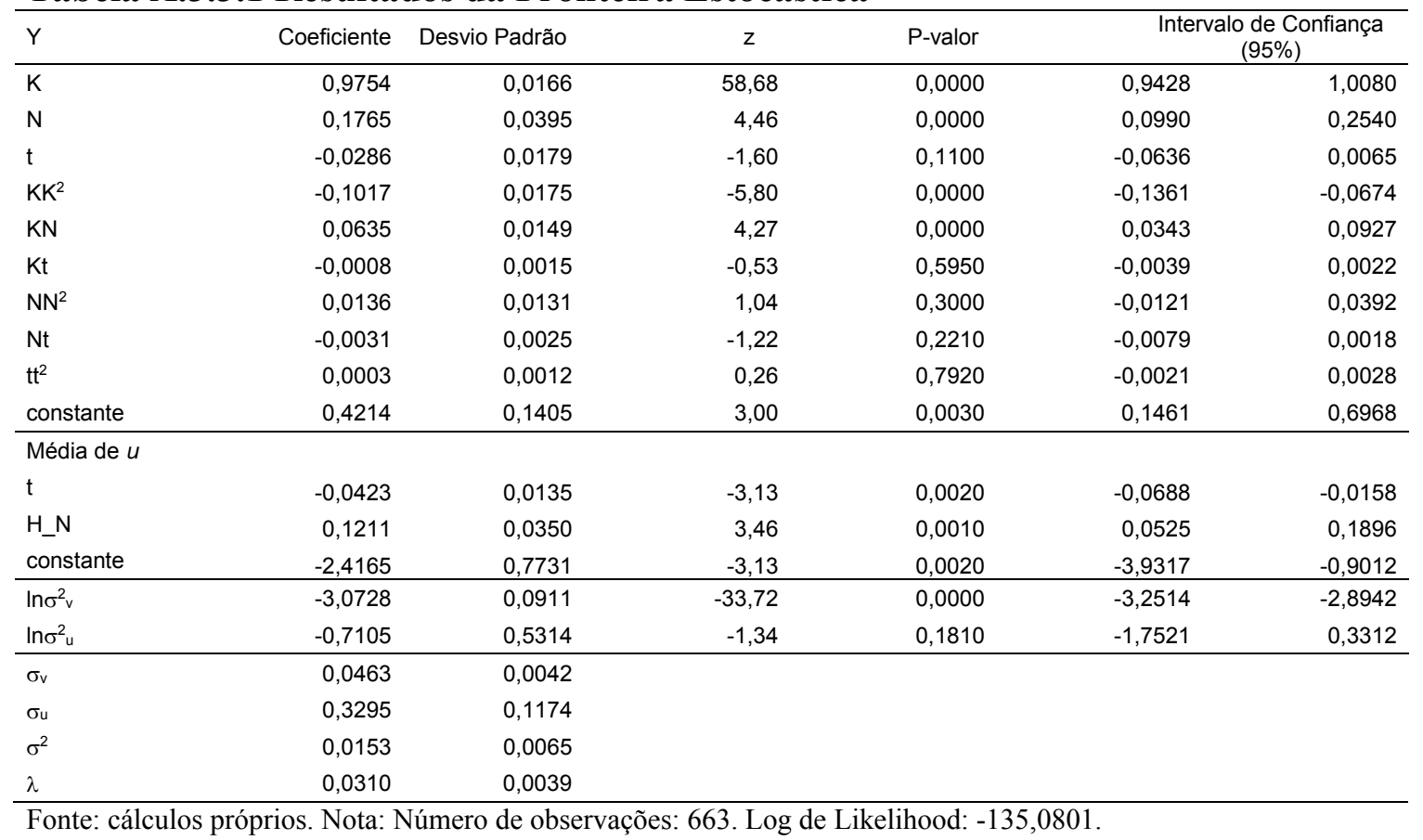

\section{Apêndice 3.2. Descrição dos testes de raiz unitária}

Os testes de raiz unitária em painel foram desenvolvidos como uma alternativa para aumentar o poder dos testes de raiz unitária individuais (análise de séries de tempo), os quais têm poder limitado, particularmente, em amostras pequenas $(T<40)$. Eles foram desenvolvidos a partir dos anos 1990 e os principais trabalhos na área são: Levin e Lin (1993), Levin, Lin e Chu (2002), Harris e Tzavalis (1999), Breitung (2000), Breitung e Das (2005), Im, Pesaran e Shin (2003), Maddala e Wu (1999), Hadri (2000) e Hadri e Larsson (2005). Esses trabalhos fazem parte da chamada primeira geração de testes de raiz unitária em painel.

A hipótese básica na qual se baseiam é a mesma dos testes de raiz unitária em séries de tempo, ou seja, a condição de estacionariedade do processo estocástico. As séries são consideradas processos estocásticos $\left\{y_{i t}\right\}$ em painel com $i=1, \ldots, N$ indivíduos e $t=1, \ldots, T$ observações. Os testes de raiz unitária determinam se os processos $\left\{y_{i t}\right\}$ são integrados para algum dos indivíduos ou para todos os indivíduos do painel, dependendo do teste. Como no caso de séries de tempo, é possível incluir termos deterministas (intercepto ou tendência) nas equações que des- 
crevem e estimam os processos. Outra hipótese comum aos testes é a pressuposição de que há independência de seções cruzadas (cross-section independence). ${ }^{80}$

A maioria dos testes de cointegração em painel parte da regressão de Dickey e Fuller Aumentado (ADF):

(A.5) $\Delta y_{i t}=\rho y_{i t-1}+\sum_{L=1}^{p_{i}} \theta_{i L} \Delta y_{i t-L}+\delta_{m i} d_{m t}+\varepsilon_{i t}$ para $m=1,2,3$.

em que $d_{m t}$ indica o vetor de variáveis deterministas e $\delta_{m i}$ o correspondente vetor de coeficientes para os modelos $m=1,2,3$. Particularmente, $d_{1 t}=\{$ conjunto vazio $\}, d_{2 t}=\{1\}$ e $d_{3 t}=\{1, t\} ; p_{i}$ indica o número de defasagens.

Em geral, os testes trabalham com a hipótese nula de painel contendo uma raiz unitária contra duas possibilidades de hipótese alternativa: (i) a hipótese alternativa homogênea para a qual todos os indivíduos do painel são estacionários; e (ii) a hipótese alternativa heterogênea, em que alguns, mas não todos, os indivíduos do painel contêm uma raiz unitária. Há ainda aqueles que trabalham com a hipótese nula de estacionariedade.

O teste de e Levin, Lin e Chu (2002) (LLC) foi desenvolvido para testar a presença de uma raiz unitária em painéis de tamanho moderado $^{81}$, mas nos quais $N$ e $T$ tendem para infinito. Um resumo com as hipóteses assintóticas dos testes da primeira geração é apresentado no Quadro A.3.2.1. Assume-se que o processo estocástico $\left\{y_{i t}\right\}$ é gerado por um dos três casos da equação (A.5). No modelo 1 , o teste avalia a hipótese nula $\mathrm{H}_{0}: \rho=0$ contra a alternativa $\mathrm{H}_{1}: \rho<0$. No modelo 2, a série $\left\{y_{i t}\right\}$ tem uma constante específica para cada indivíduo. Nesse caso, o teste avalia a hipótese nula $\mathrm{H}_{0}: \rho_{i}=0$ e $\alpha_{0 i}=0$ para todo $i$, contra $\mathrm{H}_{1}: \rho_{i}<0$ e $\alpha_{0 i} \in R$. Finalmente, no modelo 3, a série $\left\{y_{i t}\right\}$ tem constante específica e tendência linear. Nesse caso, o teste também avalia a hipótese nula $\mathrm{H}_{0}: \rho_{i}=0$ e $\alpha_{0 i}=0$ para todo $i$, contra $\mathrm{H}_{1}: \rho_{\mathrm{i}}<0$ e $\alpha_{1 i} \in R$. O processo do termo de erro $\varepsilon_{i t}$ é independentemente distribuído e segue um processo ARMA estacionário e invertível para cada indivíduo, conforme a equação abaixo. Isso significa que as séries de tempo individuais podem exibir correlação serial:

$$
\varepsilon_{i t}=\sum_{j=1}^{\infty} \gamma_{i j} \varepsilon_{i t-j}+u_{i t}
$$

O teste de Harris e Tzavalis (1999) (HT) foi desenvolvido para painéis em que há poucos períodos de tempo ( $T$ pequeno) e muitos indivíduos ( $N$ grande). Diferentemente do teste LLC, a hipótese assintótica sobre a qual o teste foi construído é de que $T$ é fixo e $N$ tende a infi-

\footnotetext{
${ }^{80}$ Os testes da segunda geração relaxam essa hipótese, ou seja, pressupõe que há dependência de seção cruzada. Os principais trabalhos nessa linha são: Pesaran (2004), Phillips e Sul (2003), Choi (2001), Bai e Ng (2004) e Pesaran (2007).

${ }^{81}$ O primeiro trabalho na área desses autores foi Levin e Lin (1993). Nos dois casos, são considerados painéis de tamanho moderado aqueles com tamanho entre 10 a 250 observações de indivíduos e 25 a 250 períodos de tempo.
} 
nito. O teste é feito para os três modelos básicos da equação (A.5). Testa-se a hipótese nula de painel com uma raiz unitária contra a hipótese alternativa de painel estacionário.

O teste sugerido por Im, Pesaran e Shin (2003) (IPS) é do tipo "média de grupo". São propostos 2 testes: o primeiro baseado na estatística $t$ da regressão ADF (equação A.5) e o segundo baseado no multiplicador de Lagrange. Admite-se apenas os modelos 2 e 3. Assumem-se duas possibilidades para o termo de erro. No caso de $\varepsilon_{i t}$ ser um ruído branco parte-se de $N \rightarrow \infty$ e $T$ fixo, no caso de $\varepsilon_{i t}$ ser serialmente correlacionado deve ser aplicado a um painel com $N \rightarrow \infty$ e $T \rightarrow \infty, N / T \rightarrow k>0$. Na hipótese nula, cada série do painel contém uma raiz unitária, $\rho_{\mathrm{i}}=0$, e na hipótese alternativa heterogênea alguns indivíduos, mas não todos, têm uma raiz unitária.

O uso de testes do tipo ADF em painel traz um viés que não acontece em séries de tempo. Isso ocorre porque um painel há dados de seção cruzada, o que introduz um montante substancial de características individuais e não observadas na variância das séries. A introdução de correção para esse tipo de viés - denominado viés de Nickell - diminui o poder do teste. Para contornar esse problema, um tipo de estatística $t$ que não requer a correção de viés foi desenvolvido. Essa estatística é baseada em uma regressão MQO simples aplicada a variáveis transformadas.

Nessa linha, Breitung (2000) (UB) propõe um teste que não usa a correção de viés como feito nos testes LLC e IPS. O procedimento inicial do teste é semelhante ao LLC. Na hipótese nula o painel tem uma raiz unitária e, na hipótese alternativa, todas as séries são estacionárias (hipótese homogênea). A diferença é que os resíduos obtidos pela regressão MQO da equação (A.5) são transformados usando a ortogonalização de Arellano e Bover (1995). O teste é construído para um painel com $N \rightarrow \infty$ seguido de $T \rightarrow \infty$. (Ver Quadro A.3.2.1)

Maddala e Wu (1999) (MW) propõe um teste de raiz unitária em painel do tipo Fisher $(1932)^{82}$. Choi (2001) também obteve um teste similar que se diferencia apenas na escala, neste caso a normalidade assintótica é obtida para $N \rightarrow \infty$. No caso do teste MW pressupõe-se $T$ e $N$ fixo. O procedimento do teste é baseado na implementação de um teste ADF para cada indivíduo do painel e é estimado um p-valor. O teste é valido para os três modelos, na equação (A.5), $m=1,2$ e 3 . Uma vantagem desse procedimento é que ele não requer que o painel seja balanceado nem que o número de defasagens seja o mesmo para todos os indivíduos.

Os dois últimos testes são baseados na generalização do teste KPSS de séries de tempo. A diferença básica desse teste com relação aos outros é que ele parte da hipótese nula de que o painel é estacionário. O teste proposto por Hadri (2000) $\left(\mathrm{H}_{\mathrm{LM}}\right)$ é um teste LM aplicado aos resíduos de MQO. Parte da hipótese nula de que o painel é estacionário em todas as unidades, ou

\footnotetext{
${ }^{82}$ Segundo Hlouskova e Wagner (2006) a ideia básica de Fisher (1932) pode ser explicada seguindo uma observação que vale para qualquer teste com estatística contínua: primeiro sob a hipótese nula, o $p$-valor, $\pi$, é uniformemente distribuído no intervalo [0,1]. Segundo, $-2 \log \pi$ mé distribuído como $x_{2}^{2}$. Terceiro, para um conjunto independente de testes estatísticos, $-2 \log \sum_{i=1}^{N} \log \pi_{i}$ é consequentemente distribuído como $\chi_{2 N}^{2}$ sob a hipótese nula.
} 
seja, não há raiz unitária em qualquer uma das séries do painel, contra a hipótese alternativa de que há uma raiz unitária em todas as séries. Esse teste só é valido para os modelos 2 e 3, ou seja, para os casos em que há a presença de termos deterministas. O teste de Hadri e Larson (2005) $\left(\mathrm{H}_{\mathrm{T}}\right)$ estende o trabalho de Hadri (2000), permitindo heterocedasticidade entre as unidades $i$ (ver quadro A.3.2.1).

Quadro A.3.2.1 Especificações assintóticas dos testes

\begin{tabular}{|l|l|}
\hline LLC & $N \rightarrow \infty$ seguido de $T \rightarrow \infty, N / T \rightarrow 0$, para caso 2 e 3. \\
\hline HT & $N \rightarrow \infty$ e $T$ fixo \\
\hline UB & $N \rightarrow \infty$ seguido de $T \rightarrow \infty$ \\
\hline IPS & $\begin{array}{l}\text { ruído branco: } N \rightarrow \infty \text { e } T \text { fixo } \\
\text { correlação serial: } N \rightarrow \infty \text { seguido de } T \rightarrow \infty, N / T \rightarrow k>0\end{array}$ \\
\hline MW & $N, T$ fixo, aproximação de um p-valor de um ADF para $T$ finito. \\
\hline $\mathrm{H}_{\text {LM }}$ & $N \rightarrow \infty$ seguido de $T \rightarrow \infty$ \\
\hline $\mathrm{H}_{\mathrm{T}}$ & $N \rightarrow \infty$ e $T$ fixo \\
\hline
\end{tabular}

Fonte: Hlouskova e Wagner (2006)

\section{Apêndice 3.3. Descrição dos testes de cointegração}

Os testes de cointegração em painel devem ser feitos quando as variáveis analisadas são não estacionárias, pois uma regressão entre elas poderia ser espúria. Assim como os testes de raiz unitária em painel, os testes de cointegração em painel são, em geral, mais poderosos do que aqueles aplicados aos dados em séries de tempo. Os testes em séries de tempo têm baixo poder principalmente quando a dimensão de séries de tempo é pequena. Segundo Baltagi (2008), agrupam-se dados de países semelhantes, como G7, OECD ou países da zona do Euro, na esperança de que, ao adicionar variações de seção cruzada aos dados, eles aumentem tanto o poder dos testes de raiz unitária quanto o de cointegração.

Há dois conjuntos de teste de cointegração em painel na literatura. O primeiro conjunto de testes é baseado nos resíduos da regressão. A metodologia desses testes consiste, basicamente, em aplicar um teste de raiz unitária aos resíduos da regressão estimada. Se os resíduos forem estacionários, então existe cointegração, o que implica que existe uma relação estável de longo prazo entre as variáveis. Nessa linha estão os trabalhos de McCoskey e Kao (1998), Kao (1999) e Pedroni (1999, 2000, 2004), Westerlund (2005). O segundo conjunto de testes parte da ideia de Johansen (1995) e Banerjee, Dolado e Mestre (1998), que utiliza o modelo de correção de erro no teste de cointegração. Nessa visão, há cointegração se existir uma variável que corrija os desequilíbrios de curto prazo. Entre esses trabalhos estão Larsson, Lyhagen e Lothgren (2001), Groen e Kleibergen (2003) e Westerlund (2007).

Os testes de cointegração baseado nos resíduos partem de um painel com as seguintes características:

$$
y_{i t}=\delta_{i}^{\prime} d_{t}+\gamma_{i} x_{i t}+e_{i t} .
$$


em que $i=1, \ldots, N ; t=1, \ldots, T ; d_{t}=(1, t)^{\prime}$ representam os termos deterministas. Se $d_{t}=0$, então $y_{i t}$ não tem termos deterministas, se $d_{t}=1$, então, $y_{i t}$ é gerado com constante e se $d_{t}=(1, t)^{\prime}$, então $y_{i t}$ é gerado com constante e tendência; $y_{i t}$ e $x_{i t}$ são $I(1)$ e $e_{i t}$ são os resíduos que representam os desvios da relação de longo prazo.

Os testes de cointegração de Kao (1999) e Pedroni $(1999,2000,2004)$ para painel são baseados nos resíduos da estimação da equação (A.6). O teste de raiz unitária é aplicado aos resíduos autorregressivos especificados na equação (A.7). A hipótese nula de não cointegração é dada por $\rho_{i}=1$. Na metodologia de Kao (1999), aplica-se um teste de raiz unitária do tipo ADF.

(A.7) $e_{i t}=\rho_{i} e_{i t-1}+\mu_{i t}$.

Pedroni $(1999,2004)$ apresenta dois conjuntos de estatísticas para o teste de cointegração também baseado nos resíduos A hipótese nula é de não cointegração. O primeiro conjunto é composto por 4 estatísticas e é calculado na dimensão "within" do painel. As estatísticas, chamadas de teste de painel, são: (i) panel v; (ii) panel $\rho$, análoga à estatística $\rho$ de Phillips e Perron; (iii) panel $t$ (paramétrica), análoga a estatística $t$ de Phillips e Perron; e (iv) panel $t$ (não paramétrico), análoga a estatística $t$ de Dickey-Fuller Aumentado. Essas estatísticas agrupam os coeficientes autorregressivos dos indivíduos para aplicar o teste de raiz unitária nos resíduos estimados. O segundo conjunto é baseado na dimensão "between" do painel e são chamadas de teste de grupo: (i) group $\rho$, análoga à estatística $\rho$ de Phillips e Perron; (ii) group $t$ análoga a estatística $t$ de Phillips e Perron e (iii) group $t$ análoga a estatística $t$ de Dickey-Fuller Aumentado. As estatísticas do teste de grupo são baseadas nas médias dos coeficientes autorregressivos individuais associados ao teste de raiz unitária dos resíduos para cada indivíduo do painel.

As estatísticas devem ser padronizadas usando as médias e variâncias computadas por Pedroni (1999). Se a estatística padronizada for menor que o valor crítico de uma distribuição normal padronizada, então a hipótese nula de não cointegração é rejeitada, implicando a existência de uma relação de longo prazo entre as variáveis analisadas.

Os testes de cointegração baseados nos resíduos podem falhar na rejeição da hipótese nula de não cointegração. Uma explicação para isso reside no fato de que os testes baseados nos resíduos requerem que o vetor de cointegração de longo prazo seja igual aos ajustamentos de curto prazo, dado pelas variáveis em suas diferenças. Kremers, Ericsson e Dolado (1992) mostraram que essa falha pode causar uma perda significativa de poder desses testes de cointegração. Westerlund (2007) propôs 4 novos testes baseados na dinâmica estrutural. Esses testes foram desenhados para verificar, na hipótese nula, se o termo de correção de erro, em um modelo condicional de correção de erros, é nulo. Se essa hipótese for rejeitada, então não há uma variável que atua corrigindo os desequilíbrios de curto prazo e, portanto, não há cointegração. O teste desenvolvido por Westerlund (2007) parte do seguinte modelo condicional de correção de erros: 
(A.8) $\Delta y_{i t}=\delta_{i}^{\prime} d_{t}+\alpha_{i}\left(y_{i t-1}-\beta_{i}^{\prime} x_{i t-1}\right)+\sum_{j=1}^{p_{i}} \alpha_{i j} \Delta y_{i t-j}+\sum_{j=0}^{p_{i}} \gamma_{i j} \Delta x_{i t-j}+\varepsilon_{i t}$.

em que $i=1, \ldots, N ; t=1, \ldots, T ; d_{t}=(1, t)^{\prime}$ representam os termos deterministas. $\delta_{i}=\left(\delta_{1 i}, \delta_{2 i}\right)^{\prime}$ representa o vetor de parâmetros. O vetor $x_{i t}$, de dimensão $k$, é modelado como um random walk, dessa forma $\Delta x_{i t}$ é independente de $\varepsilon_{i t}$. Assume-se também que os erros são independentes entre $i$ e $t$.

Note-se que o modelo de correção de erros só pode ser estável se todas as variáveis forem estacionárias. Então a relação, $y_{i t-1}-\beta_{i}^{i} x_{i t-1}$ deve ser estacionária. Se isso for válido, o vetor $\beta_{i}$ define a relação de longo prazo entre $x_{i t}$ e $y_{i t}$, resultando em erros estacionários. Qualquer desvio desse equilíbrio leva a uma correção de proporção $-2 \leq \alpha_{i}<0$. Se $\alpha_{i}<0$, então há correção de erros, o que implica que $y_{i t}$ e $x_{i t}$ são cointegradas, se $\alpha_{i}=0$, não há correção de erros e não haverá cointegração. Desse modo, o teste de Westerlund (2007) tem em sua hipótese nula $\mathrm{H}_{0}: \alpha_{i}=0$, contra a hipótese alternativa $\mathrm{H}_{1}: \alpha_{i}<0$. Para implantar o teste é necessário estimar o componente de correção de erros $\left(\alpha_{i}\right)$. Para isso, pode-se reescrever a equação (A.8):

$$
\Delta y_{i t}=\delta_{i}^{\prime} d_{t}+\alpha_{i} y_{i t-1}+\lambda_{i}^{\prime} x_{i t-1}+\sum_{j=1}^{p_{i}} \alpha_{i j} \Delta y_{i t-j}+\sum_{j=0}^{p_{i}} \gamma_{i j} \Delta x_{i t-j}+\varepsilon_{i t} .
$$

em que $\lambda_{i}=\alpha_{i} \beta_{i}$. Nessa regressão, o parâmetro $\alpha_{i}$ não é afetado por $\beta_{i}$, isso significa que uma estimação de $\alpha_{i}$ por MQO pode ser empreendida provendo um teste válido de $\mathrm{H}_{0}$ contra $\mathrm{H}_{1}$. Com base na equação (A.9) foram desenvolvidas 4 estatísticas do teste. As duas primeiras estatísticas são do tipo "mean group" e as outras duas estatísticas são chamadas de "panel statistics". As estatísticas de "mean group" podem ser computadas por meio de três passos: (i) estima-se a equação (A.9) por MQO; (ii) estima-se $\alpha_{i}(1)$ por meio de uma abordagem paramétrica ou usando o estimador de kernel; e (iii) computa-se a estatística do teste:

$$
G_{\tau}=\frac{1}{N} \sum_{i=1}^{N} \frac{\hat{\alpha}_{i}}{S E\left(\hat{\alpha}_{i}\right)} \text { e } G_{\alpha}=\frac{1}{N} \sum_{i=1}^{N} \frac{T \hat{\alpha}_{i}}{\hat{\alpha}_{i}(1)},
$$

em que $S E\left(\hat{\alpha}_{i}\right)$ é o erro padrão de $\hat{\alpha}_{i}$. 


\section{Apêndice 3.4 Tabelas complementares de cointegração}

Tabela A.3.4.1 Resultados da estimação por efeito fixo, 39 países, 1995 a 2011

\begin{tabular}{|c|c|c|c|}
\hline Investimento (In) & Coeficiente & $\mathrm{t}$ & p-valor \\
\hline Crédito (In) & 0,3394 & 26,03 & 0,0000 \\
\hline Retorno do capital & 3,5686 & 12,75 & 0,0000 \\
\hline Preço relativo do capital & $-1,1348$ & $-14,19$ & 0,0000 \\
\hline constante & 16,5507 & 44,79 & 0,0000 \\
\hline$\sigma_{u}$ & 1,1675 & & \\
\hline$\sigma_{e}$ & 0,1497 & & \\
\hline$\underline{\rho}$ & 0,9838 & & \\
\hline $\mathrm{R}^{2}$ overall & 0,8787 & & \\
\hline Número de observações & 663 & & \\
\hline
\end{tabular}

Cálculos próprios. $\sigma_{u}$ é o desvio padrão de $u_{i}, \sigma_{e}$ é o desvio padrão de $e_{i t}$ e $\rho$ é a parcela da variância devida a $u_{i}$.

Tabela A.3.4.2 Resultados da estimação por efeito fixo, 39 países, 1995 a 2011

\begin{tabular}{|c|c|c|c|}
\hline Investimento (In) & Coeficiente & $\mathrm{t}$ & $\mathrm{p}$-valor \\
\hline Crédito (In) & 0,3592 & 28,4 & 0,0000 \\
\hline Retorno esperado do capital & 3,1113 & 13,01 & 0,0000 \\
\hline Preço relativo do capital & $-1,2136$ & $-14,94$ & 0,0000 \\
\hline constante & 15,7544 & 43,66 & 0,0000 \\
\hline$\sigma_{u}$ & 1,2188 & & \\
\hline$\sigma_{e}$ & 0,1490 & & \\
\hline$\rho$ & 0,9853 & & \\
\hline $\mathrm{R}^{2}$ overall & 0,8257 & & \\
\hline Número de observações & 663 & & \\
\hline
\end{tabular}

Cálculos próprios. $\sigma_{u}$ é o desvio padrão de $u_{i}, \sigma_{e}$ é o desvio padrão de $e_{i t}$ e $\rho$ é a parcela da variância devida a $u_{i}$.

Tabela A.3.4.3 Resultados da estimação por efeito fixo, 39 países, 1995 a 2011

\begin{tabular}{|c|c|c|c|}
\hline Investimento (In) & Coeficiente & $\mathrm{t}$ & $\mathrm{p}$-valor \\
\hline Crédito (In) & 0,3030 & 16,18 & 0,0000 \\
\hline Retorno do capital & 3,5226 & 6,95 & 0,0000 \\
\hline Preço relativo do capital & $-1,2481$ & $-14,68$ & 0,0000 \\
\hline Taxa de juros de longo prazo & $-0,8446$ & $-5,44$ & 0,0000 \\
\hline constante & 17,7734 & 32,31 & 0,0000 \\
\hline$\sigma_{u}$ & 1,2499 & & \\
\hline$\sigma_{e}$ & 0,1226 & & \\
\hline$\rho$ & 0,9905 & & \\
\hline $\mathrm{R}^{2}$ overall & 0,8642 & & \\
\hline Número de observações & 483 & & \\
\hline
\end{tabular}

Cálculos próprios. $\sigma_{u}$ é o desvio padrão de $u_{i}, \sigma_{e}$ é o desvio padrão de $e_{i t}$ e $\rho$ é a parcela da variância devida a $u_{i}$.

Tabela A.3.4.4 Resultados da estimação por efeito fixo, 39 países, 1995 a 2011

\begin{tabular}{|c|c|c|c|}
\hline Investimento (In) & Coeficiente & $\mathrm{t}$ & $\mathrm{p}$-valor \\
\hline Crédito (In) & 0,2946 & 13,4 & 0,0000 \\
\hline Retorno do capital & 3,5314 & 6,96 & 0,0000 \\
\hline Preço relativo do capital & $-1,2510$ & $-14,68$ & 0,0000 \\
\hline Taxa de juros de longo prazo & $-0,8371$ & $-5,38$ & 0,0000 \\
\hline Taxa real de câmbio & 0,0249 & 0,72 & 0,4700 \\
\hline constante & 17,9649 & 29,41 & 0,0000 \\
\hline$\sigma_{u}$ & 1,27001 & & \\
\hline$\sigma_{e}$ & 0,12267 & & \\
\hline$\rho$ & 0,99076 & & \\
\hline $\mathrm{R}^{2}$ overall & 0,8584 & & \\
\hline Número de observações & 483 & & \\
\hline
\end{tabular}

Cálculos próprios. $\sigma_{u}$ é o desvio padrão de $u_{i}, \sigma_{e}$ é o desvio padrão de $e_{i t} \mathrm{e} \rho$ é a parcela da variância devida a $u_{i}$. 
Apêndice 3.5 Tabelas complementares de contabilidade de crescimento

Tabela A.3.5.1 Decomposição do crescimento do PIB, por país, 1995 a 2003 (\% ao ano)

\begin{tabular}{|c|c|c|c|c|}
\hline País & $g_{Y}$ & $g_{A}$ & $s_{K} \cdot g_{K}$ & $s_{N} \cdot g_{N}$ \\
\hline Austrália & $3,79 \%$ & $2,24 \%$ & $0,46 \%$ & $1,09 \%$ \\
\hline Áustria & $2,26 \%$ & $0,93 \%$ & $0,77 \%$ & $0,56 \%$ \\
\hline Bélgica & $2,09 \%$ & $0,50 \%$ & $0,98 \%$ & $0,60 \%$ \\
\hline Bulgária & $0,80 \%$ & $0,88 \%$ & $0,29 \%$ & $-0,37 \%$ \\
\hline Brasil & $2,31 \%$ & $0,10 \%$ & $1,36 \%$ & $0,86 \%$ \\
\hline Canadá & $3,44 \%$ & $1,08 \%$ & $1,21 \%$ & $1,15 \%$ \\
\hline China & $8,82 \%$ & $6,22 \%$ & $2,01 \%$ & $0,59 \%$ \\
\hline Chipre & $3,36 \%$ & $1,62 \%$ & $0,64 \%$ & $1,10 \%$ \\
\hline República Checa & $1,79 \%$ & $0,90 \%$ & $1,22 \%$ & $-0,32 \%$ \\
\hline Alemanha & $1,39 \%$ & $0,33 \%$ & $0,81 \%$ & $0,25 \%$ \\
\hline Dinamarca & $1,99 \%$ & $0,83 \%$ & $0,64 \%$ & $0,51 \%$ \\
\hline Espanha & $3,58 \%$ & $-0,06 \%$ & $1,40 \%$ & $2,25 \%$ \\
\hline Estônia & $6,95 \%$ & $4,80 \%$ & $2,62 \%$ & $-0,47 \%$ \\
\hline Finlândia & $3,69 \%$ & $1,73 \%$ & $0,86 \%$ & $1,09 \%$ \\
\hline França & $2,18 \%$ & $0,86 \%$ & $0,57 \%$ & $0,75 \%$ \\
\hline Reino Unido & $2,94 \%$ & $1,08 \%$ & $1,15 \%$ & $0,71 \%$ \\
\hline Grécia & $3,71 \%$ & $0,92 \%$ & $2,35 \%$ & $0,44 \%$ \\
\hline Hungria & $3,74 \%$ & $3,13 \%$ & $0,24 \%$ & $0,37 \%$ \\
\hline Indonésia & $1,64 \%$ & $0,12 \%$ & $1,02 \%$ & $0,49 \%$ \\
\hline Índia & $6,09 \%$ & $2,14 \%$ & $2,82 \%$ & $1,13 \%$ \\
\hline Irlanda & $7,77 \%$ & $1,79 \%$ & $3,46 \%$ & $2,52 \%$ \\
\hline Itália & $1,36 \%$ & $-0,20 \%$ & $0,75 \%$ & $0,81 \%$ \\
\hline Japão & $0,81 \%$ & $1,26 \%$ & $-0,06 \%$ & $-0,39 \%$ \\
\hline República da Coréia & $5,41 \%$ & $3,44 \%$ & $1,21 \%$ & $0,76 \%$ \\
\hline Lituânia & $5,76 \%$ & $3,56 \%$ & $2,44 \%$ & $-0,24 \%$ \\
\hline Luxemburgo & $4,64 \%$ & $1,15 \%$ & $1,27 \%$ & $2,22 \%$ \\
\hline Látvia & $5,98 \%$ & $3,33 \%$ & $2,45 \%$ & $0,19 \%$ \\
\hline México & $3,38 \%$ & $3,13 \%$ & $-0,86 \%$ & $1,11 \%$ \\
\hline Malta & $2,83 \%$ & $0,80 \%$ & $1,43 \%$ & $0,60 \%$ \\
\hline Holanda & $2,73 \%$ & $0,60 \%$ & $0,82 \%$ & $1,30 \%$ \\
\hline Polônia & $3,92 \%$ & $4,12 \%$ & $0,63 \%$ & $-0,83 \%$ \\
\hline Portugal & $2,67 \%$ & $-0,61 \%$ & $2,26 \%$ & $1,01 \%$ \\
\hline Romênia & $1,20 \%$ & $0,52 \%$ & $0,63 \%$ & $0,06 \%$ \\
\hline Rússia & $2,07 \%$ & $1,28 \%$ & $0,72 \%$ & $0,07 \%$ \\
\hline Eslováquia & $3,72 \%$ & $1,49 \%$ & $2,35 \%$ & $-0,12 \%$ \\
\hline Eslovênia & $3,98 \%$ & $2,27 \%$ & $1,70 \%$ & $0,01 \%$ \\
\hline Suécia & $3,05 \%$ & $1,42 \%$ & $1,18 \%$ & $0,45 \%$ \\
\hline Turquia & $4,30 \%$ & $1,92 \%$ & $2,24 \%$ & $0,14 \%$ \\
\hline Estados Unidos & $3,56 \%$ & $1,35 \%$ & $1,61 \%$ & $0,61 \%$ \\
\hline
\end{tabular}


Tabela A.3.5.2 Decomposição do crescimento do PIB por país, 2003 a 2011 (\% ao ano)

\begin{tabular}{|c|c|c|c|c|}
\hline País & $g_{Y}$ & $g_{A}$ & $s_{K}^{*} g_{K}$ & $s_{N} \cdot g_{N}$ \\
\hline Austrália & $2,71 \%$ & $-1,52 \%$ & $2,90 \%$ & $1,33 \%$ \\
\hline Áustria & $1,84 \%$ & $0,54 \%$ & $0,66 \%$ & $0,64 \%$ \\
\hline Bélgica & $1,54 \%$ & $-0,05 \%$ & $0,87 \%$ & $0,72 \%$ \\
\hline Bulgária & $2,73 \%$ & $0,68 \%$ & $1,76 \%$ & $0,28 \%$ \\
\hline Brasil & $4,05 \%$ & $-0,09 \%$ & $2,54 \%$ & $1,60 \%$ \\
\hline Canadá & $2,93 \%$ & $0,91 \%$ & $1,29 \%$ & $0,73 \%$ \\
\hline China & $10,97 \%$ & $5,16 \%$ & $5,36 \%$ & $0,44 \%$ \\
\hline Chipre & $2,60 \%$ & $0,49 \%$ & $0,90 \%$ & $1,20 \%$ \\
\hline República Checa & $3,33 \%$ & $1,70 \%$ & $1,30 \%$ & $0,34 \%$ \\
\hline Alemanha & $1,48 \%$ & $0,25 \%$ & $0,57 \%$ & $0,66 \%$ \\
\hline Dinamarca & $0,67 \%$ & $-0,38 \%$ & $0,97 \%$ & $0,08 \%$ \\
\hline Espanha & $1,45 \%$ & $-0,03 \%$ & $1,33 \%$ & $0,16 \%$ \\
\hline Estônia & $2,89 \%$ & $0,11 \%$ & $2,50 \%$ & $0,28 \%$ \\
\hline Finlândia & $1,87 \%$ & $0,58 \%$ & $0,79 \%$ & $0,50 \%$ \\
\hline França & $1,33 \%$ & $0,81 \%$ & $0,33 \%$ & $0,19 \%$ \\
\hline Reino Unido & $1,13 \%$ & $-0,62 \%$ & $1,07 \%$ & $0,68 \%$ \\
\hline Grécia & $0,33 \%$ & $-2,31 \%$ & $1,45 \%$ & $1,20 \%$ \\
\hline Hungria & $0,96 \%$ & $0,27 \%$ & $1,05 \%$ & $-0,37 \%$ \\
\hline Indonésia & $6,09 \%$ & $2,59 \%$ & $2,36 \%$ & $1,15 \%$ \\
\hline Índia & $8,86 \%$ & $3,47 \%$ & $4,98 \%$ & $0,41 \%$ \\
\hline Irlanda & $1,75 \%$ & $-1,48 \%$ & $2,92 \%$ & $0,32 \%$ \\
\hline Itália & $0,18 \%$ & $-0,70 \%$ & $0,56 \%$ & $0,32 \%$ \\
\hline Japão & $0,65 \%$ & $1,19 \%$ & $0,12 \%$ & $-0,66 \%$ \\
\hline República da Coréia & $4,77 \%$ & $2,91 \%$ & $1,02 \%$ & $0,84 \%$ \\
\hline Lituânia & $3,26 \%$ & $0,93 \%$ & $2,38 \%$ & $-0,05 \%$ \\
\hline Luxemburgo & $3,05 \%$ & $-0,03 \%$ & $1,37 \%$ & $1,71 \%$ \\
\hline Látvia & $2,96 \%$ & $1,24 \%$ & $2,76 \%$ & $-1,03 \%$ \\
\hline México & $2,23 \%$ & $0,57 \%$ & $0,79 \%$ & $0,87 \%$ \\
\hline Malta & $2,61 \%$ & $0,87 \%$ & $0,64 \%$ & $1,09 \%$ \\
\hline Holanda & $1,68 \%$ & $0,35 \%$ & $0,81 \%$ & $0,52 \%$ \\
\hline Polônia & $4,54 \%$ & $1,92 \%$ & $1,55 \%$ & $1,07 \%$ \\
\hline Portugal & $1,07 \%$ & $-0,01 \%$ & $1,24 \%$ & $-0,16 \%$ \\
\hline Romênia & $3,54 \%$ & $1,00 \%$ & $1,65 \%$ & $0,89 \%$ \\
\hline Rússia & $4,38 \%$ & $2,10 \%$ & $2,22 \%$ & $0,06 \%$ \\
\hline Eslováquia & $4,96 \%$ & $2,43 \%$ & $2,10 \%$ & $0,43 \%$ \\
\hline Eslovênia & $2,28 \%$ & $1,32 \%$ & $0,82 \%$ & $0,14 \%$ \\
\hline Suécia & $2,27 \%$ & $0,55 \%$ & $1,30 \%$ & $0,43 \%$ \\
\hline Turquia & $6,27 \%$ & $2,60 \%$ & $3,03 \%$ & $0,63 \%$ \\
\hline Estados Unidos & $1,71 \%$ & $0,36 \%$ & $1,33 \%$ & $0,02 \%$ \\
\hline
\end{tabular}

Fonte: WIOD e WDI, cálculos próprios. (*) Para simplificar a exposição dos resultados, a taxa $g_{A}$ inclui a variação da ineficiência $u$ definida nas equações do Capítulo 2 . 
Tabela A.3.5.3 Variações observadas e esperadas na taxa de acumulação de capital, países, 1995 a 2003 contra 2003 a 2011, pontos percentuais

\begin{tabular}{|c|c|c|c|}
\hline País & Esperado & Observado & Diferença \\
\hline Austrália & 4,38 p.p. & 6,10 p.p. & -1,73 p.p. \\
\hline Áustria & 0,88 p.p. & $-0,50$ p.p. & 1,37 p.p. \\
\hline Bélgica & $-0,05$ p.p. & $-0,22$ p.p. & 0,17 p.p. \\
\hline Bulgária & 0,64 p.p. & 3,14 p.p. & $-2,51$ p.p. \\
\hline Brasil & 1,92 p.p. & 2,82 p.p. & $-0,90$ p.p. \\
\hline Canadá & $-0,69$ p.p. & 0,14 p.p. & $-0,83$ p.p. \\
\hline China & 13,93 p.p. & 5,09 p.p. & 8,84 p.p. \\
\hline Chipre & $-0,11$ p.p. & 0,92 p.p. & -1,03 p.p. \\
\hline República Checa & 1,66 p.p. & 0,39 p.p. & 1,27 p.p. \\
\hline Alemanha & 0,84 p.p. & $-0,85$ p.p. & 1,70 p.p. \\
\hline Dinamarca & 1,92 p.p. & 1,16 p.p. & 0,76 p.p. \\
\hline Espanha & 0,29 p.p. & $-0,50$ p.p. & 0,79 p.p. \\
\hline Estônia & 1,04 p.p. & $-0,17$ p.p. & 1,20 p.p. \\
\hline Finlândia & 0,22 p.p. & $-0,11$ p.p. & 0,33 p.p. \\
\hline França & $-0,10$ p.p. & $-0,64$ p.p. & 0,53 p.p. \\
\hline Reino Unido & 0,82 p.p. & 0,07 p.p. & 0,76 p.p. \\
\hline Grécia & $-0,07$ p.p. & -1,68 p.p. & 1,61 p.p. \\
\hline Hungria & 1,81 p.p. & 2,03 p.p. & $-0,23$ p.p. \\
\hline Indonésia & $-0,02$ p.p. & 2,34 p.p. & $-2,36$ p.p. \\
\hline Índia & 0,77 p.p. & 3,53 p.p. & $-2,76$ p.p. \\
\hline Irlanda & 0,39 p.p. & -1,09 p.p. & 1,48 p.p. \\
\hline Itália & 0,47 p.p. & -0,47 p.p. & 0,94 p.p. \\
\hline Japão & 0,27 p.p. & 0,42 p.p. & $-0,15$ p.p. \\
\hline República da Coréia & $-0,51$ p.p. & -1,09 p.p. & 0,58 p.p. \\
\hline Lituânia & 1,39 p.p. & $-0,07$ p.p. & 1,46 p.p. \\
\hline Luxemburgo & 1,74 p.p. & 0,07 p.p. & 1,67 p.p. \\
\hline Látvia & 0,18 p.p. & 1,06 p.p. & $-0,88$ p.p. \\
\hline México & 2,17 p.p. & 2,57 p.p. & $-0,41$ p.p. \\
\hline Malta & $-0,45$ p.p. & $-1,87$ p.p. & 1,42 p.p. \\
\hline Holanda & 1,29 p.p. & $-0,37$ p.p. & 1,66 p.p. \\
\hline Polônia & 3,42 p.p. & $-0,17$ p.p. & 3,59 p.p. \\
\hline Portugal & $-0,24$ p.p. & -2,91 p.p. & 2,67 p.p. \\
\hline Romênia & 1,04 p.p. & 2,90 p.p. & $-1,86$ p.p. \\
\hline Rússia & 1,63 p.p. & 3,54 p.p. & -1,91 p.p. \\
\hline Eslováquia & 1,30 p.p. & $-0,77$ p.p. & 2,07 p.p. \\
\hline Eslovênia & 1,04 p.p. & $-3,66$ p.p. & 4,70 p.p. \\
\hline Suécia & 0,11 p.p. & 0,55 p.p. & $-0,44$ p.p. \\
\hline Turquia & 2,63 p.p. & 1,09 p.p. & 1,54 p.p. \\
\hline Estados Unidos & 1,35 p.p. & $-0,85$ p.p. & 2,20 p.p. \\
\hline
\end{tabular}

Fonte: WIOD e WDI, cálculos próprios. 
Tabela A.3.5.4 Variações observadas e esperadas na taxa crescimento econômico, países, 1995 a 2003 contra 2003 a 2011, pontos percentuais

\begin{tabular}{|c|c|c|c|}
\hline País & Esperado & Observado & Diferença \\
\hline Austrália & 1,01 p.p. & -1,09 p.p. & 2,10 p.p. \\
\hline Áustria & 0,21 p.p. & $-0,05$ p.p. & 0,26 p.p. \\
\hline Bélgica & $-0,15$ p.p. & $-0,07$ p.p. & $-0,08$ p.p. \\
\hline Bulgária & 0,13 p.p. & 0,24 p.p. & $-0,11$ p.p. \\
\hline Brasil & 0,51 p.p. & 0,22 p.p. & 0,30 p.p. \\
\hline Canadá & -0,42 p.p. & $-0,06$ p.p. & $-0,36$ p.p. \\
\hline China & 6,73 р.p. & 0,27 p.p. & 6,46 p.p. \\
\hline Chipre & $-0,15$ p.p. & $-0,10$ p.p. & $-0,06$ p.p. \\
\hline República Checa & 0,46 p.p. & 0,19 p.p. & 0,27 p.p. \\
\hline Alemanha & 0,22 p.p. & 0,01 p.p. & 0,21 p.p. \\
\hline Dinamarca & 0,40 p.p. & $-0,17$ p.p. & 0,56 p.p. \\
\hline Espanha & -0,07 p.p. & $-0,27$ p.p. & 0,20 p.p. \\
\hline Estônia & $-0,09$ p.p. & $-0,51$ p.p. & 0,41 p.p. \\
\hline Finlândia & $-0,04$ p.p. & $-0,23$ p.p. & 0,19 p.p. \\
\hline França & $-0,07$ p.p. & $-0,11$ p.p. & 0,04 p.p. \\
\hline Reino Unido & 0,02 p.p. & $-0,23$ p.p. & 0,24 p.p. \\
\hline Grécia & $-0,20$ p.p. & $-0,42$ p.p. & 0,23 p.p. \\
\hline Hungria & 0,59 p.p. & $-0,35$ p.p. & 0,93 p.p. \\
\hline Indonésia & $-0,26$ p.p. & 0,56 p.p. & $-0,82$ p.p. \\
\hline Índia & -0,62 p.p. & 0,35 p.p. & $-0,97$ p.p. \\
\hline Irlanda & $-0,45$ p.p. & $-0,75$ p.p. & 0,31 p.p. \\
\hline Itália & 0,09 p.p. & -0,15 p.p. & 0,24 p.p. \\
\hline Japão & 0,11 p.p. & $-0,02$ p.p. & 0,13 p.p. \\
\hline República da Coréia & $-0,43$ p.p. & $-0,08$ p.p. & $-0,35$ p.p. \\
\hline Lituânia & 0,35 p.p. & $-0,31$ p.p. & 0,67 p.p. \\
\hline Luxemburgo & 0,65 p.p. & $-0,20$ p.p. & 0,85 p.p. \\
\hline Látvia & $-0,36$ p.p. & $-0,38$ p.p. & 0,01 p.p. \\
\hline México & 1,43 p.p. & $-0,14$ p.p. & 1,57 p.p. \\
\hline Malta & $-0,25$ p.p. & $-0,03$ p.p. & $-0,22$ p.p. \\
\hline Holanda & 0,31 p.p. & $-0,13$ p.p. & 0,44 p.p. \\
\hline Polônia & 1,24 p.p. & 0,08 p.p. & 1,16 p.p. \\
\hline Portugal & $-0,33$ p.p. & $-0,20$ p.p. & $-0,13$ p.p. \\
\hline Romênia & 0,05 p.p. & 0,29 p.p. & $-0,24$ p.p. \\
\hline Rússia & 0,34 p.p. & 0,29 p.p. & 0,05 p.p. \\
\hline Eslováquia & 0,68 p.p. & 0,15 p.p. & 0,53 p.p. \\
\hline Eslovênia & 0,01 p.p. & $-0,21$ p.p. & 0,22 p.p. \\
\hline Suécia & $-0,22$ p.p. & $-0,10$ p.p. & $-0,12$ p.p. \\
\hline Turquia & 1,37 p.p. & 0,25 p.p. & 1,13 p.p. \\
\hline Estados Unidos & 0,35 p.p. & $-0,23$ p.p. & 0,58 p.p. \\
\hline
\end{tabular}

Fonte: WIOD e WDI, cálculos próprios. 


\section{Apêndice 4.1 Crédito Hipotecário no Brasil, 1909 a 1934}

Tabela A.4.1.1 Número de inscrições hipotecárias

\begin{tabular}{lrrrr}
\hline \multirow{2}{*}{ Ano } & \multirow{2}{*}{ Total do Brasil } & \multicolumn{3}{c}{ Por área } \\
\cline { 3 - 5 } & 10.416 & Urbana & Rural & Não discriminada \\
\hline 1909 & 13.458 & 6.902 & 3.514 & NA \\
1919 & 21.349 & 7.730 & 5.728 & NA \\
1924 & 29.691 & NA & NA & 21.349 \\
1929 & 12.536 & 20.722 & 8.941 & 28 \\
1934 & 9.814 & 2.414 & 308 \\
\hline
\end{tabular}

Fonte: Anuário estatístico do Brasil (vários anos).

Tabela A.4.1.2 Valor das inscrições hipotecárias em contos de réis de 1934

\begin{tabular}{lrrrr}
\hline \multirow{2}{*}{ Ano } & \multirow{2}{*}{ Total do Brasil } & \multicolumn{3}{c}{ Por área } \\
\cline { 3 - 5 } & & Urbana & Rural & Não discriminada \\
1909 & 402.691 & 215.203 & 187.488 & NA \\
1919 & 553.437 & 291.353 & 262.084 & NA \\
1924 & 849.412 & NA & NA & 849.412 \\
1929 & 1.420 .652 & 845.319 & 573.400 & 1.934 \\
1934 & 562.922 & 447.518 & 108.978 & 6.426 \\
\hline
\end{tabular}

Fonte: Anuário estatístico do Brasil (vários anos).

Tabela A.4.1.3 Número de inscrições hipotecárias, por faixa de valor em contos de réis, Brasil

\begin{tabular}{|c|c|c|c|c|}
\hline & 1909 & 1924 & 1929 & $1934^{*}$ \\
\hline Até $500 \$$ & 538 & 183 & 117 & - \\
\hline mais de $500 \$$ a $1.000 \$$ & 1.200 & 683 & 574 & 222 \\
\hline mais de $1.000 \$$ a $5.000 \$$ & 4.713 & 5.844 & 7.119 & 2.871 \\
\hline mais de $5.000 \$$ a $10.000 \$$ & 1.747 & 3.974 & 6.090 & 2.782 \\
\hline mais de $10.000 \$$ a $50.000 \$$ & 1.786 & 6.029 & 10.932 & 5.188 \\
\hline mais de $50.000 \$$ a $100.000 \$$ & 223 & 932 & 1.950 & 835 \\
\hline mais de $100.000 \$$ & 209 & 888 & 1.933 & 638 \\
\hline não discriminadas & - & 2.816 & 948 & 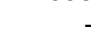 \\
\hline Total & 10.416 & 21.349 & 29.663 & 12.536 \\
\hline
\end{tabular}

Nota: (*) A primeira faixa é de até 1.000\$. Fonte: Anuário estatístico do Brasil (vários anos).

Tabela A.4.1.4 Valor das inscrições hipotecárias, em contos de réis, por faixa de valor em mil réis, Brasil

\begin{tabular}{|c|c|c|c|c|}
\hline & 1909 & 1924 & 1929 & $1934^{*}$ \\
\hline Até $500 \$$ & 205 & 77 & 46 & - \\
\hline mais de $500 \$$ a $1.000 \$$ & 1.044 & 622 & 522 & 185 \\
\hline mais de $1.000 \$$ a $5.000 \$$ & 13.476 & 18.777 & 24.241 & 9.756 \\
\hline mais de $5.000 \$$ a $10.000 \$$ & 13.681 & 31.951 & 49.242 & 22.259 \\
\hline mais de $10.000 \$$ a $50.000 \$$ & 40.974 & 146.779 & 269.358 & 125.328 \\
\hline mais de $50.000 \$$ a $100.000 \$$ & 16.591 & 73.840 & 146.957 & 61.351 \\
\hline mais de $100.000 \$$ & 74.464 & 403.743 & 990.734 & 344.043 \\
\hline não discriminadas & - & 143.166 & 28.055 & - \\
\hline Total & 160.435 & 818.955 & 1.509 .155 & 562.922 \\
\hline
\end{tabular}

Nota: (*) A primeira faixa é de até 1.000 mil réis. Fonte: Anuário estatístico do Brasil (vários anos).

Tabela A.4.1.5 Número de inscrições hipotecárias, por faixa de taxa de juros do financiamento, Brasil

\begin{tabular}{|c|c|c|c|c|}
\hline & 1909 & 1924 & 1929 & $1934^{*}$ \\
\hline Até $5 \%$ & 108 & 169 & 226 & 126 \\
\hline mais de $5 \%$ a $10 \%$ & 2.376 & 4.989 & 4.481 & 9.544 \\
\hline mais de $10 \%$ a $15 \%$ & 5.393 & 9.815 & 14.337 & 475 \\
\hline mais de $20 \%$ a $25 \%$ & 385 & 681 & 2.092 & NA \\
\hline mais de $25 \%$ & 18 & 95 & 333 & NA \\
\hline Total & 10.416 & 21.349 & 29.663 & 12.536 \\
\hline
\end{tabular}

Nota: (*) Não apresentou valores descriminados para as faixas: mais de $15 \%$ a $20 \%$ em diante. Ou seja, a terceira faixa representa todas as hipotecas com mais de 15\% de juros. Fonte: Anuário estatístico do Brasil (vários anos). 
Tabela A.4.1.6 Valor das inscrições hipotecárias, em contos de réis de 1934, por faixa de taxa de juros do financiamento, Brasil

\begin{tabular}{lrrrr}
\hline & 1909 & 1924 & 1929 & $1934^{*}$ \\
\hline Até 5\% & 3.463 & 4.728 & 28.841 & 5.996 \\
mais de 5\% a 10\% & 201.691 & 394.912 & 600.868 & 443.774 \\
mais de 10\% a 15\% & 137.696 & 228.611 & 568.646 & 9.291 \\
mais de 15\% a 20\% & 10.812 & 14.003 & 72.227 & NA \\
mais de 20\% a 25\% & 2.865 & 5.614 & 24.240 & NA \\
mais de 25\% & 250 & 456 & 3.258 & NA \\
não estipulada & 45.915 & 52.571 & 94.265 & 103.861 \\
não discriminadas & $\mathrm{NA}$ & 148.516 & 26.374 & NA \\
\hline Total & $\mathbf{4 0 2 . 6 9 1}$ & $\mathbf{8 4 9 . 4 1 2}$ & $\mathbf{1 . 4 1 8 . 7 1 9}$ & $\mathbf{5 6 2 . 9 2 2}$ \\
\hline
\end{tabular}

Nota: $(*)$ Não apresentou valores descriminados para as faixas: mais de $15 \%$ a $20 \%$ em diante. Ou seja, a terceira faixa representa todas as hipotecas com mais de $15 \%$ de juros. Fonte: Anuário estatístico do Brasil (vários anos).

Tabela A.4.1.7 Número de inscrições hipotecárias, por prazo de financiamento, Brasil

\begin{tabular}{lrrrr}
\hline & 1909 & 1924 & 1929 & 1934 \\
\hline Até 6 meses & 472 & 614 & 1.257 & 302 \\
mais de 6 meses a 1 ano & 2.471 & 3.520 & 5.928 & 1.929 \\
mais de 1 ano a 2 anos & 3.024 & 4.529 & 7.784 & 3.016 \\
mais de 2 anos a 3 anos & 1.923 & 3.720 & 6.670 & 2.417 \\
mais de 3 anos a 4 anos & 764 & 1.357 & 2.043 & 779 \\
mais de 4 anos a 5 anos & 704 & 1.247 & 2.088 & 948 \\
mais de 5 anos a 15 anos & 710 & 807 & 1.762 & 2.397 \\
mais de 15 anos & 46 & 41 & 368 & 171 \\
indeterminado & 302 & 396 & 815 & 577 \\
não discriminadas & NA & 5.118 & 948 & NA \\
\hline Total & $\mathbf{1 0 . 4 1 6}$ & $\mathbf{2 1 . 3 4 9}$ & $\mathbf{2 9 . 6 6 3}$ & $\mathbf{1 2 . 5 3 6}$ \\
\hline
\end{tabular}

Fonte: Anuário estatístico do Brasil (vários anos).

Tabela A.4.1.8 Valor das inscrições hipotecárias, em contos de réis de 1934, por prazo de financiamento, Brasil

\begin{tabular}{lrrrr}
\hline & 1909 & 1924 & 1929 & 1934 \\
\hline Até 6 meses & 9.174 & 13.662 & 44.054 & 6.288 \\
mais de 6 meses a 1 ano & 61.289 & 100.506 & 256.995 & 43.100 \\
mais de 1 ano a 2 anos & 70.640 & 116.257 & 223.068 & 71.821 \\
mais de 2 anos a 3 anos & 58.371 & 117.089 & 213.154 & 68.468 \\
mais de 3 anos a 4 anos & 25.922 & 51.120 & 105.467 & 29.772 \\
mais de 4 anos a 5 anos & 42.172 & 57.247 & 124.113 & 41.036 \\
mais de 5 anos a 15 anos & 61.976 & 50.778 & 225.607 & 196.803 \\
mais de 15 anos & 64.471 & 91.019 & 111.576 & 43.871 \\
indeterminado & 8.676 & 24.632 & 88.312 & 61.763 \\
não discriminadas & NA & 227.103 & 26.374 & NA \\
\hline Total & $\mathbf{4 0 2 . 6 9 1}$ & $\mathbf{8 4 9 . 4 1 2}$ & $\mathbf{1 . 4 1 8 . 7 1 9}$ & $\mathbf{5 6 2 . 9 2 2}$ \\
\hline
\end{tabular}

Fonte: Anuário estatístico do Brasil (vários anos).

\section{Apêndice 4.2 Crédito total do Banco do Brasil, 1938 a 1945}

Tabela A.4.2.1 Empréstimos concedidos pelo Banco do Brasil 1938-1945, em mil Cr\$

\begin{tabular}{|c|c|c|c|c|c|c|c|c|c|c|c|c|c|}
\hline & \multicolumn{4}{|c|}{ Governo } & \multirow[b]{2}{*}{ Bancos } & \multicolumn{2}{|c|}{$\begin{array}{c}\text { Carteira de Crédito } \\
\text { Geral (1) }\end{array}$} & \multicolumn{4}{|c|}{ CREAI } & \multirow[b]{2}{*}{$\begin{array}{r}\text { Total } \\
\text { geral } \\
(2)\end{array}$} & \multirow[b]{2}{*}{$\begin{array}{r}\text { Índice } \\
1942= \\
100\end{array}$} \\
\hline & Diversos & DNC & Total & $\begin{array}{c}\text { Índice } \\
1942= \\
100\end{array}$ & & $\begin{array}{r}\text { Comércio } \\
\text { e Con- } \\
\text { sumi- } \\
\text { dores }\end{array}$ & $\begin{array}{r}\text { Índice } \\
1938= \\
100\end{array}$ & Rural & Industrial & Total & $\begin{array}{c}\text { Índice } \\
1942= \\
100\end{array}$ & & \\
\hline 1938 & 2.132 & 237 & 2.369 & 68 & 191 & 740 & 47 & 22 & 2 & 24 & 2 & 3.324 & 53 \\
\hline 1939 & 2.419 & 216 & 2.635 & 75 & 171 & 904 & 58 & 96 & 28 & 124 & 12 & 3.834 & 61 \\
\hline 1940 & 2.332 & 203 & 2.535 & 72 & 159 & 1.130 & 72 & 250 & 76 & 326 & 30 & 4.150 & 66 \\
\hline 1941 & 2.185 & 369 & 2.554 & 73 & 138 & 1.132 & 72 & 478 & 130 & 608 & 57 & 4.432 & 70 \\
\hline 1942 & 3.069 & 429 & 3.498 & 100 & 188 & 1.565 & 100 & 837 & 237 & 1.074 & 100 & 6.325 & 100 \\
\hline 1943 & 4.661 & 445 & 5.106 & 146 & 152 & 1.496 & 96 & 1.152 & 264 & 1.416 & 132 & 8.170 & 129 \\
\hline 1944 & 6.481 & 436 & 6.917 & 198 & 212 & 2.017 & 129 & 2.056 & 420 & 2.476 & 231 & 11.622 & 184 \\
\hline 1945 & 3.713 & 303 & 4.016 & 115 & 265 & 2.695 & 172 & 4.305 & 518 & 4.823 & 449 & 11.799 & 187 \\
\hline
\end{tabular}

Fonte: Banco do Brasil, Silva (2007). Notas: (1) Concessões de crédito contratadas com empresas comerciais e consumidores; (2) Não foram computados os empréstimos em letras hipotecárias em razão de não terem sido realizados em espécie (Banco do Brasil: 1947, p.68). 


\section{Apêndice 4.3 Fontes de recursos e desembolsos do BNDE}

\section{Tabela A.4.3.1 Recursos do BNDE no período 1952-1959 (Cr\$ mil)}

\begin{tabular}{|c|c|c|c|c|c|c|c|c|}
\hline Recursos & 1952 & 1953 & 1954 & 1955 & 1956 & 1957 & 1958 & 1959 \\
\hline I- Recursos Potenciais & 1.419 & 2.659 & 3.452 & 6.749 & 13.185 & 17.083 & 22.885 & 31.712 \\
\hline 1. Recursos Próprios & 1.419 & 2.659 & 3.452 & 4.582 & 5.643 & 6.645 & 8.814 & 12.026 \\
\hline A. Fundo de Reaparelhamento Econômico & 1.398 & 2.651 & 3.316 & 4.175 & 5.447 & 5.602 & 6.930 & 8.700 \\
\hline a. Adicionais Imposto de Renda & 1.398 & 1.690 & 2.228 & 2.959 & 3.889 & 4.432 & 5.103 & 6.500 \\
\hline b. Cia. Seg. E Capitalização & & 185 & 170 & 153 & 196 & 247 & 375 & 500 \\
\hline c. Caixas Econômicas & & 549 & 660 & 747 & 906 & 923 & 1.452 & 1.700 \\
\hline d. Inst. De Previdência Social & & 227 & 258 & 316 & 456 & & & \\
\hline B. Outros Recursos Próprios & 21 & 8 & 136 & 407 & 196 & 1.043 & 1.884 & 3.326 \\
\hline a. Capital Social & 20 & & & & & & & \\
\hline b. Dividendo Soc. Econ. Mista & & & & & & 186 & 203 & 476 \\
\hline c. Saldo Operacional & 1 & 8 & 58 & 265 & 41 & 589 & 1.224 & 2.298 \\
\hline d. Amortizações financiamentos concedidos & & & 78 & 142 & 155 & 268 & 457 & 552 \\
\hline 2. Recursos Especiais & & & & & 1.568 & 2.210 & 2.000 & 3.000 \\
\hline A. 1o Acordo Excedentes Agrícolas & & & & & 1.568 & & & \\
\hline B. 2o Acordo Excedentes Agrícolas & & & & & & 2.210 & 2.000 & 3.000 \\
\hline 3. Recursos Vinculados & & & & 2.167 & 5.974 & 8.228 & 12.071 & 16.686 \\
\hline A. Capital da Rede Ferroviária Federal & & & & & & 826 & & \\
\hline B. Fundo Renovação Patrimonial & & & & 284 & 1.090 & 1.119 & 973 & 1.070 \\
\hline C. Fundo Melhoramento de Ferrovias & & & & 284 & 1.090 & 1.119 & 973 & 1.070 \\
\hline D. Fundo Federal Eletrificação & & & & 1.093 & 1.328 & 1.420 & 2.117 & 2.479 \\
\hline E. Imposto sobre Energia Elétrica $-60 \%$ & & & & 506 & 638 & 718 & 832 & 899 \\
\hline F. Fundo Pavimentação & & & & & 1.462 & 2.421 & 2.865 & 3.000 \\
\hline G. Fundo Especial para Substituição Ramais Deficitários & & & & & 366 & 605 & 716 & 900 \\
\hline H. Fundo Marinha Mercante & & & & & & & 1.809 & 3.496 \\
\hline I. Taxa Renovação Marinha Mercante (Armadores) & & & & & & & 252 & 509 \\
\hline J. Fundo Portuário & & & & & & & 1.534 & 3.263 \\
\hline II. Recursos efetivos & 391 & 1.213 & 772 & 2.103 & 3.558 & 11.234 & 15.340 & 25.972 \\
\hline III. “Déficit” Anual Entrega Recursos (I-II) & 1.028 & 1.446 & 2.680 & 4.646 & 9.627 & 5.849 & 7.545 & 5.740 \\
\hline IV. "Déficit" Acumulado Anos Anteriores & & 1.028 & 2.474 & 5.154 & 9.800 & 19.427 & 25.276 & 32.821 \\
\hline V. Capacidade Potencia Aplicação Anual (I-IV) & 1.419 & 3.687 & 5.926 & 11.903 & 22.985 & 37.183 & 48.161 & 64.533 \\
\hline
\end{tabular}

Fonte: VIII Exposição sobre o Programa de Reaparelhamento Econômico - 1959 - BNDE. Memorias do Desenvolvimento, vol. $2,2008$. 
Tabela A.4.3.2 Desembolsos do BNDE com Operações Contratadas, segundo os setores de atividade econômica, em mil Cr\$

\begin{tabular}{|c|c|c|c|c|c|}
\hline Setores de atividade & 1953 & 1956 & 1959 & 1962 & 1965 \\
\hline TRANSPORTES & 277,7 & $1.792,20$ & $1.531,90$ & 304,2 & 315 \\
\hline Ferrovias & 277,7 & $1.792,20$ & $1.531,90$ & 304,2 & 163 \\
\hline Navegação, Porto e Dragagem & & & & & 152 \\
\hline ENERGIA ELÉTRICA & 100 & 463,4 & $4.115,60$ & $6.494,20$ & $22.428,00$ \\
\hline INDÚSTRIAS BÁSICAS & 30 & 127,4 & $2.028,80$ & $2.736,40$ & $25.536,00$ \\
\hline Metalúrgica & & 48,6 & $1.304,00$ & $1.556,00$ & $13.886,00$ \\
\hline Siderurgia & & 38,5 & $1.034,30$ & $1.146,00$ & $11.711,00$ \\
\hline Metalurgia dos não ferrosos & & & 173,3 & 370 & $1.212,00$ \\
\hline Metalúrgicas diversas & & 10,1 & 96,4 & 40 & 963 \\
\hline Mecânica & & & 6 & 24 & 700 \\
\hline Material Ferroviário & 30 & & 48,8 & & $3.840,00$ \\
\hline Automobilística & & 28 & 207,7 & 260,4 & 223 \\
\hline Construção Naval & & & 50 & 102 & \\
\hline Material Elétrico & & 14,9 & 117 & & \\
\hline Celulose e Papel & & 25 & 200 & 34 & 2 \\
\hline Química & & 10,9 & 95,3 & 690 & $5.930,00$ \\
\hline Outras Indústrias & & & & 70 & 955 \\
\hline $\begin{array}{l}\text { SETORES COMPLEMENTARES DA AGRICUL- } \\
\text { TURA }\end{array}$ & 7,2 & 76 & 248 & 571 & 698 \\
\hline Matadouros industriais & & 52 & 96 & 65,5 & 310 \\
\hline Armazéns e silos & 7,2 & 4 & 152 & 405,5 & 278 \\
\hline Armazéns e frigoríficos & & 20 & & 100 & 110 \\
\hline REPASSE A BANCOS DE DESENVOLVIMENTO & & & & & $2.365,00$ \\
\hline $\begin{array}{l}\text { APLICAÇÕES À CONTA DE FUNDOS ESPECÍ- } \\
\text { FICOS }\end{array}$ & & & & & $33.424,00$ \\
\hline FUNTEC & & & & & 361 \\
\hline FIPEME & & & & & 595 \\
\hline FINAME & & & & & $32.454,00$ \\
\hline FINEP & & & & & 14 \\
\hline OUTRAS APLICAÇÕES & & & & & 235 \\
\hline TOTAL & 414,9 & $2.459,00$ & $7.924,30$ & $10.105,80$ & $85.001,00$ \\
\hline
\end{tabular}

Fonte: VIII Exposição sobre o Programa de Reaparelhamento Econômico - 1959 - BNDE. Memorias do Desenvolvimento, vol. 2, 2008. 


\section{Apêndice 4.4 O BNDE e a Reforma Financeira}

\section{Quadro A.4.4.1 Principais fundos criados com as reformas da década de 1960}

Fundo Características

Fundo de Desenvolvimento Técnico Científico (FUNTEC), 1964

Fundo Agroindustrial de Reconversão (FUNAR), 1964

Fundo de Financiamento para Aquisição de Máquinas e Equipamentos Industriais (FINAME), 1964

Programa de Financiamento à Pequena e Média Empresas (FIPEME), 1965

Fundo de Financiamento de Estudos de Projetos e Programas (FINEP), 1965
Voltado para o incremento dos níveis de produção e produtividade do setor agrícola.

(i) Voltado para o financiamento de operações de compra e venda de máquinas e equipamentos de produção nacional. (ii) Voltado sobretudo para a implantação de novas indústrias de pequeno porte $e$, quando possível, para financiar a expansão de indústrias já existentes. (iii) $A$ partir de 1965, passaria a constituir uma subconta do Fundo Geral para Agricultura e Indústria (FUNAGRI) nos livros e papéis do BNDE. (iv) A partir de 1966, adquiriu personalidade jurídica própria, transformando-se, em seguida, em sociedade de economia mista, cujo controle acionário caberia ao BNDE.

(i) Fundo rotativo voltado para investimentos fixos no sentido de instalar e/ou expandir empreendimentos de pequeno e médio portes. (ii) Aquisição de equipamentos de fabricação nacional ou estrangeira, obras de construção civil, bem como despesas de instalação de equipamentos e serviços técnicos.

(i) Voltado para financiar a realização de estudos de viabilidade de projetos específicos. (ii) Constitui uma subconta do FUNAGRI.
Fontes de recursos

Recursos do próprio Banco, por meio dos saldos operacionais e de parte da receita do Adicional ao Imposto de Renda.

(i) $10 \%$ dos recursos do Fundo Nacional de Reforma Agrária. (ii) Empréstimos contraídos no país e no exterior. (iii) Recursos do próprio BNDE. (iv) Recursos transferidos ao Fundo por outras entidades governamentais.

(i) Empréstimos ou doações de entidades internacionais, nacionais ou estrangeiras. (ii) Recursos colocados à sua disposição pelo Banco do Brasil S.A. e outras agências financeiras da União ou dos estados. (iii) Recursos mobilizados pelo BNDE nos mercados interno e externo de capitais. (iv) Rendimento das próprias operações do Fundo.

Empréstimos do BID e do Banco de Reconstrução Federal da Alemanha.

(i) Empréstimos ou doações de entidades financeiras nacionais ou estrangeiras. (ii) Recursos provenientes de dotações orçamentárias. (iii) Rendimentos oriundos de suas operações.

Fonte: Exposição sobre o Programa de Reaparelhamento Econômico, BNDE, vários anos. Tavares et al (2010).

Tabela A.4.4.1 Operações aprovadas do BNDE por setor de atividades em mil NCr\$, 1964 a 1967

\begin{tabular}{|c|c|c|c|c|c|c|}
\hline Ano & $\begin{array}{l}\text { Transportes e } \\
\text { comunicações }\end{array}$ & Energia & Siderurgia & $\begin{array}{r}\text { Indústrias } \\
\text { diversas }\end{array}$ & $\begin{array}{r}\text { Outras } \\
\text { atividades } \\
\end{array}$ & Total \\
\hline 1964 & - & $21.109,3$ & $74.240,5$ & $7.563,3$ & 727,9 & $103.641,0$ \\
\hline 1965 & 150,0 & $3.927,2$ & $243.316,5$ & $97.990,9$ & $10.644,5$ & $356.029,1$ \\
\hline 1966 & - & $64.297,2$ & $242.150,0$ & $217.526,6$ & $7.280,0$ & $531.253,8$ \\
\hline 1967 & $1.944,0$ & $183.700,0$ & $272.954,0$ & $248.388,6$ & $45.700,2$ & $752.686,8$ \\
\hline
\end{tabular}

Nota: no setor industrial se inclui a indústria de transformação. O total inclui as operações do FINAME. Fonte: XVIII Exposição sobre o Programa de Reaparelhamento Econômico, BNDE, 1969. Tavares et al (2010). 


\section{Apêndice 6.1 Resultados da fronteira para cálculo do retorno esperado do capital}

A estimativa de retorno esperado do capital (produtividade marginal do capital) empregada na seção 6.2 foi obtida a partir de uma modelo econométrico que estimou a elasticidade do capital para uma função de produção. Isso foi necessário porque as Contas Nacionais do Brasil não dispunham de dados regulares sobre a distribuição funcional da renda até o início dos anos 1990. A metodologia empregada à empregada no Capítulo 3 - Ver Apêndice 3.1. A única diferença é que a estimativa da ineficiência pressupõe que a variável $u$ tenha distribuição aleatória meia-normal incondicional.

O modelo de fronteira estocástica foi estimado para uma amostra de 100 países entre 1953 e 2013. Os dados foram obtidos no Penn World Table 7.1 (Heston, Summers e Aten, 2012) e World Development Indicator on line (WB, 2014). Os países da amostra são: Argentina, Austrália, Áustria, Bangladesh, Barbados, Bélgica, Benin, Bolívia, Botswana, Brasil, Burkina Faso, Burundi, Cabo Verde, Camarões, Canada, Chile, China, Colômbia, Comoros, Congo, Dem. Rep., Congo, Rep., Costa Rica, Cote d'Ivoire, Dinamarca, República Dominicana, Equador, Egito, República da Arábia, El Salvador, Etiópia, Fiji, Finlândia, France, Gabon, Gambia, Alemanha, Ghana, Grécia, Guatemala, Guinea, Honduras, Islândia, Índia, Indonésia, Iran, República Islâmica, Irlanda, Israel, Itália, Jamaica, Japão, Jordan, Kenya, República da Coreia, Lesotho, Luxemburgo, Madagascar, Malawi, Malásia, Mauritânia, Mauritius, México, Marrocos, Moçambique, Nepal, Holanda, Nova Zelândia, Nicarágua, Niger, Nigéria, Noruega, Paquistão, Panamá, Papua Nova Guine, Paraguai, Peru, Filipinas, Portugal, Rússia, Ruanda, Senegal, Seychelles, Singapore, África do Sul, Espanha, Sri Lanka, Suécia, Suíça, República da Síria, Tanzânia, Tailândia, Togo, Trinidad e Tobago, Tunísia, Turquia, Uganda, Reino Unido, Estados Unidos, Uruguai, Venezuela, Zâmbia, e Zimbabwe. A seguir são apresentadas as descrições das variáveis:

- PIB: corresponde ao Produto Interno Bruto em dólares de 2010, ajustado à paridade do poder de compra. A variável foi transformada em logaritmo natural (ln).

- Estoque de capital: esta variável foi construída a partir da formação bruta de capital fixo por meio da técnica do inventário perpétuo. Considerou-se $5 \%$ de depreciação do capital. A variável também foi transformada em logaritmo natural (ln).

- Força de trabalho: corresponde a população com 15 anos de idade ou mais velhos que oferta trabalho para a produção de mercadorias e serviços do país. Inclui empregados e desempregados. Em geral, inclui as pessoas que trabalham nas forças armadas e exclui trabalhadores domésticos sem remuneração. Essa variável também foi transformada em logaritmo natural (ln).

O resultado da estimação da fronteira estocástica para esse painel é apresentado na Tabela A.6.1.1. Nota-se que todos os coeficientes estimados apresentam os sinais esperados e são estatisticamente significativos. 


\begin{tabular}{|c|c|c|c|c|c|c|}
\hline \multirow{2}{*}{$\begin{array}{l}\mathrm{Y} \\
\mathrm{K}\end{array}$} & \multirow{2}{*}{$\begin{array}{r}\text { Coeficiente } \\
0,5005\end{array}$} & \multirow{2}{*}{$\begin{array}{c}\text { Desvio } \\
\text { Padrão }\end{array}$} & \multirow{2}{*}{$\begin{array}{r}z \\
99,36\end{array}$} & \multirow{2}{*}{$\begin{array}{l}\text { P-valor } \\
0,0000\end{array}$} & \multicolumn{2}{|c|}{$\begin{array}{c}\text { Intervalo de } \\
\text { Confiança (95\%) }\end{array}$} \\
\hline & & & & & 0,4906 & 0,5103 \\
\hline$N$ & 0,4621 & 0,0070 & 66,04 & 0,0000 & 0,4483 & 0,4758 \\
\hline$t$ & 0,0087 & 0,0009 & 9,78 & 0,0000 & 0,0070 & 0,0105 \\
\hline $\mathrm{KK}^{2}$ & $-0,0897$ & 0,0025 & $-36,59$ & 0,0000 & $-0,0945$ & $-0,0849$ \\
\hline KN & 0,0747 & 0,0027 & 28,03 & 0,0000 & 0,0695 & 0,0800 \\
\hline Kt & 0,0042 & 0,0001 & 32,18 & 0,0000 & 0,0040 & 0,0045 \\
\hline $\mathrm{NN}^{2}$ & $-0,0777$ & 0,0036 & $-21,76$ & 0,0000 & $-0,0847$ & $-0,0707$ \\
\hline $\mathrm{Nt}$ & $-0,0027$ & 0,0002 & $-15,26$ & 0,0000 & $-0,0030$ & $-0,0023$ \\
\hline $\mathrm{tt}^{2}$ & $-0,0002$ & 0,0000 & $-9,27$ & 0,0000 & $-0,0003$ & $-0,0002$ \\
\hline constante & 0,1932 & 0,0194 & 9,96 & 0,0000 & 0,1552 & 0,2312 \\
\hline $\ln \sigma_{v}^{2}$ & $-2,8128$ & 0,0500 & $-56,24$ & 0,0000 & $-2,9109$ & $-2,7148$ \\
\hline $\ln \sigma^{2}{ }_{u}$ & $-2,9971$ & 0,1621 & $-18,49$ & 0,0000 & $-3,3147$ & $-2,6795$ \\
\hline$\sigma_{\mathrm{v}}$ & 0,2450 & 0,0061 & & & 0,2333 & 0,2573 \\
\hline$\sigma_{\mathrm{u}}$ & 0,2235 & 0,0181 & & & 0,1906 & 0,2619 \\
\hline$\sigma^{2}$ & 0,1100 & 0,0056 & & & 0,0989 & 0,1210 \\
\hline$\lambda$ & 0,9120 & 0,0237 & & & 0,8656 & 0,9584 \\
\hline
\end{tabular}

Fonte: cálculos próprios. Nota: Número de observações: 5.939. Log de Likelihood: -852,56111.

\section{Apêndice 6.2. Descrição dos testes de raiz unitária e de cointegração}

O teste Dickey e Pantula (1987) é aplicado em duas etapas: na primeira, é testada a hipótese de existência de duas raízes contra a hipótese alternativa de uma raiz unitária; na segunda, é testada a hipótese de existência de uma raiz contra a hipótese alternativa de nenhuma raiz unitária. Nesse teste são estimadas duas equações (A.10 e A.11) por MQO e os coeficientes de $\beta_{1}$ e $\beta_{2}$ são comparados aos valores críticos calculados por Mackinnon (1991).

(A.10) $\Delta^{2} y_{t}=\alpha+\beta t+\beta_{1} \Delta y_{t-1}+\sum_{i=1}^{p-1} \delta_{i} \Delta^{2} y_{t-i}+\varepsilon_{t}$.

(A.11) $\Delta^{2} y_{t}=\alpha+\beta t+\beta_{1} \Delta y_{t-1}+\sum_{i=1}^{p-1} \delta_{i} \Delta^{2} y_{t-i}+\varepsilon_{t}$.

Nessas expressões $\beta_{1}=\rho_{1} \cdot \rho_{2}-1, \beta_{2}=-\left(1-\rho_{1}\right) .\left(1-\rho_{2}\right)$ e $p$ é o número de defasagens. ${ }^{83}$ Na primeira etapa é testado a significância de $\beta_{1}$. Se $\beta_{1}=0$, não se refuta a premissa de que há duas raízes unitárias; se $\beta_{1}<0$, então se conclui que há apenas uma raiz unitária. Na segunda etapa, a hipótese nula é $\beta_{1}<0$ e $\beta_{2}=0$ (uma raiz unitária) contra a hipótese alternativa de $\beta_{1}<0$ e $\beta_{2}<0$ (zero raiz unitária).

As equações A.10 e A.11 representam o modelo mais geral, denominado de modelo 3, o qual apresenta constante e tendência linear. O modelo 2 apresenta apenas constante e o modelo 1 não tem termos deterministas. $O$ teste para os termos deterministas deve ser comparado com

\footnotetext{
${ }^{83} \mathrm{O}$ coeficiente $\rho$ é definido no processo estocástico $y_{\mathrm{t}}=\rho y_{\mathrm{t}-1}+\varepsilon_{\mathrm{t}} \mathrm{em}$ que $\varepsilon_{\mathrm{t}}$ é um ruído branco.
} 
os valores críticos de Dickey e Fuller (1981). Além disso, deve-se definir o número de defasagens que será utilizado. ${ }^{84}$

O teste ADF testa a hipótese de existência de uma raiz unitária contra zero. É aplicado em apenas uma etapa, que consiste da estimação por MQO da equação (A.12) a seguir. O coeficiente $\gamma$ estimado deve ser comparado com os valores críticos da tabela do Dickey e Fuller (1979). ${ }^{85}$ Assim como no teste de Dickey e Pantula, é necessário empreender o teste para os termos deterministas e definir qual modelo usar (a equação A.12 traz o modelo 3). Além de definir o número de defasagens $(p)$ que será utilizado.

(A.12) $\Delta y_{t}=\alpha+\beta t+y_{t-1}+\sum_{i=1}^{p-1} \delta_{i} \Delta y_{t-i}+\varepsilon_{t}$.

O teste Generalised Least Squares Dickey-Fuller (DF-GLS) tem como objetivo encontrar um teste mais potente na presença de termos deterministas, pois nessa situação o teste ADF tem grande perda de poder. Ele estima a equação (A.12) por mínimos quadrados generalizados e aplica o teste ADF sobre o coeficiente $\gamma$ estimado. A hipótese nula é a mesma do teste ADF, as defasagens devem ser definidas pelo critério de informação de Schwarz e não há a possibilidade de teste sem termos deterministas.

O teste KPSS - Kwiatkowski et al (1992) - diferencia-se dos anteriores pelo fato de a hipótese nula ser a de estacionariedade da série. Nesse caso, quando a hipótese nula é rejeitada, há evidência de que a série é não estacionária. No teste KPSS, é testada a estacionariedade em torno da constante e da tendência; não há modelo sem constante. Para definição do número de defasagens, o teste adota o critério de Newey-West. Como não há um teste para a presença dos termos deterministas, o procedimento consiste em aplicar o teste pressupondo a presença de constante e, depois, aplicar o mesmo teste pressupondo a presença de tendência e constante.

A análise de cointegração parte do teorema da representação de Granger, o qual diz que se um vetor $X_{t}$ é cointegrado, então ele pode ser representado por um modelo de correção de erros. Assim, um modelo VAR ( $k$ ) pode ser escrito na forma de um vetor de correção de erros (VEC). Assumindo o seguinte modelo VAR:

(A.13) $X_{t}=\Pi_{1} X_{t-1}+\Pi_{2} X_{t-2}+\ldots+\Pi_{k} X_{t-k}+\varepsilon_{t}$.

em que П é uma matriz de dimensão $N \mathrm{x} N$, sendo $N$ é número de variáveis, $X_{t}$ é um vetor $N \mathrm{x} 1$ e $\varepsilon_{t}$ é um vetor de ruídos branco. Outra forma de representar esse vetor é:

\footnotetext{
${ }^{84}$ Para isso, há três critérios possíveis: a análise da autocorrelação dos resíduos da equação estimada; a análise da significância da maior defasagem; e os critérios de informação: Akaike, Schwarz e Hannan-Quinn. No Capítulo 6 foi aplicado o segundo método.

85 Assumindo que $y_{\mathrm{t}}=\rho y_{\mathrm{t}-1}+\varepsilon \mathrm{t}$, em que $\varepsilon$ é um ruído branco, a primeira diferença $y_{\mathrm{t}}-y_{\mathrm{t}-1}=(1-\rho) y_{\mathrm{t}-1}+\varepsilon_{\mathrm{t}}$ ou $\Delta y_{\mathrm{t}}=\gamma y_{\mathrm{t}-1}+\varepsilon_{\mathrm{t}}$. Se $\rho<1$ ou $\gamma<0$ o processo é estacionário.
} 
(A.14) $\Delta X_{t}=\Pi X_{t-1}+\sum_{i=1}^{k-1} \Gamma_{i} \Delta X_{t-i}+\varepsilon_{t}$, em que $\Pi=\Pi_{1}+\Pi_{2}+\ldots+\Pi_{k}-I_{N}$ e $\Gamma_{i}=-\sum_{\alpha=1+i}^{k} \Pi_{j}$.

Desse modo, se a matriz $\Pi$ puder ser fatorada em $\alpha \beta$ ', em que $\alpha$ e $\beta$ são matrizes $N x r$ com postos completos, então o modelo VAR poderá ser representado na forma de um VEC. Para isso, é necessário que o posto $(r)$ da matriz П seja incompleto. Nesse caso, existe cointegração e há $r$ vetores de cointegração linearmente independentes.

\section{Apêndice 6.3. Tabelas complementares da análise de séries de tempo}

Tabela A.6.3.1 Determinação do número de defasagens do VAR

\begin{tabular}{|c|c|c|c|c|c|c|c|c|}
\hline \multirow[t]{2}{*}{ Modelo' } & \multirow[t]{2}{*}{ Estatística } & \multicolumn{7}{|c|}{ Número de defasagens do VAR } \\
\hline & & 0 & 1 & 2 & 3 & 4 & 5 & 6 \\
\hline \multirow{3}{*}{ i } & AIC & $-0,32264$ & $-8,07470$ & $-8,08894^{*}$ & $-7,94030$ & $-7,76178$ & $-7,51122$ & $-7,67337$ \\
\hline & HQIC & $-0,28029$ & $-7,90534^{*}$ & $-7,79255$ & $-7,51689$ & $-7,21134$ & $-6,83376$ & $-6,86889$ \\
\hline & SC & $-0,21314$ & $-7,63674^{*}$ & $-7,32250$ & $-6,84539$ & $-6,33840$ & $-5,75936$ & $-5,59304$ \\
\hline \multirow{3}{*}{ ii } & AIC & $-0,44383$ & $-9,28559^{*}$ & $-9,15026$ & $-8,98295$ & $-8,75475$ & $-8,46857$ & $-8,59609$ \\
\hline & HQIC & $-0,38737$ & $-9,00331^{*}$ & $-8,64217$ & $-8,24904$ & $-7,79502$ & $-7,28303$ & $-7,18472$ \\
\hline & SC & $-0,29784$ & $-8,55565^{\star}$ & $-7,83637$ & $-7,08511$ & $-6,27296$ & $-5,40283$ & $-4,94639$ \\
\hline \multirow{3}{*}{ iii } & $\mathrm{AIC}$ & $-1,91929$ & $-10,18630$ & $-10,3009^{\star}$ & $-10,21050$ & $-10,08050$ & $-10,15860$ & $-10,27220$ \\
\hline & HQIC & $-1,86284$ & $-9,90406^{*}$ & $-9,79286$ & $-9,47661$ & $-9,12077$ & $-8,97302$ & $-8,86086$ \\
\hline & SC & $-1,77330$ & $-9,4564^{*}$ & $-8,98706$ & $-8,31267$ & $-7,59871$ & $-7,09282$ & $-6,62253$ \\
\hline
\end{tabular}

Fonte: cálculos próprios. Notas: (1) $\mathrm{O}$ asterisco indica a defasagem selecionada; (2) $\mathrm{O}$ modelo i corresponde à relação entre investimento, crédito e retorno esperado do capital; o modelo ii corresponde a relação entre investimento, crédito, retorno esperado do capital e taxa de câmbio real e o modelo iii corresponde à relação entre investimento, crédito, retorno esperado do capital e preço relativo do capital.

Tabela A.6.3.2 Determinação do número de vetores de cointegração

\begin{tabular}{|c|c|c|c|c|c|c|}
\hline \multirow[t]{2}{*}{ Modelo $^{2}$} & \multirow[t]{2}{*}{ Estatística } & \multicolumn{5}{|c|}{ Teste do traço } \\
\hline & & $r=0$ & $r \leq 1$ & $r \leq 2$ & $r \leq 3$ & $r \leq 4$ \\
\hline \multirow[t]{2}{*}{ i } & traço & 41,1327 & $6,7162^{*}$ & 0,0287 & & \\
\hline & $\mathrm{VC}^{1}$ & 24,31 & 12,53 & 3,84 & & \\
\hline \multirow[t]{2}{*}{ ii } & traço & 54,9460 & $16,7973^{*}$ & 2,0080 & 0,0109 & \\
\hline & $\mathrm{VC}^{1}$ & 39,8900 & 24,3100 & 12,5300 & 3,8400 & \\
\hline \multirow[t]{2}{*}{ iii } & traço & 55,9526 & $18,3296^{*}$ & 3,7961 & 0,0009 & \\
\hline & $\mathrm{VC}^{1}$ & 39,8900 & 24,3100 & 12,5300 & 3,8400 & \\
\hline \multirow[t]{2}{*}{ Modelo $^{2}$} & Estatística & \multicolumn{5}{|c|}{ Teste do máximo autovalor } \\
\hline & & $r=0$ & $r \leq 1$ & $r \leq 2$ & $r \leq 3$ & $r \leq 4$ \\
\hline \multirow[t]{2}{*}{ i } & máximo & 34,4164 & $6,6875^{*}$ & 0,0287 & & \\
\hline & $\mathrm{VC}^{1}$ & 17,89 & 11,44 & 3,84 & & \\
\hline \multirow[t]{2}{*}{ ii } & máximo & 38,1487 & $14,7892^{*}$ & 1,9971 & 0,0109 & \\
\hline & $\mathrm{VC}^{1}$ & 23,8000 & 17,8900 & 11,4400 & 3,8400 & \\
\hline \multirow[t]{2}{*}{ iii } & máximo & 37,6230 & $14,5335^{\star}$ & 3,7953 & 0,0009 & \\
\hline & $\mathrm{VC}^{1}$ & 23,8000 & 17,8900 & 11,4400 & 3,8400 & \\
\hline
\end{tabular}

Fonte: cálculos próprios. Notas: (1) Valor Crítico da estatística a 5\% de significância, o asterisco indica o número de vetor de cointegração. (2) O modelo i corresponde à relação entre investimento, crédito e retorno esperado do capital; o modelo ii corresponde a relação entre investimento, crédito, retorno esperado do capital e taxa de câmbio real e o modelo iii corresponde à relação entre investimento, crédito, retorno esperado do capital e preço relativo do capital. 
Tabela A.6.3.3 Autocorrelação dos resíduos - teste LM

\begin{tabular}{llrrrrrr}
\hline Modelo & & Estatística & \multicolumn{7}{c}{ Número de defasagens } \\
\cline { 3 - 8 } & & 1 & 2 & 3 & 4 & 5 & 6 \\
\hline i & $\mathrm{Chi}^{2}$ & 12,6435 & 6,1428 & 6,6014 & 3,004 & 21,624 & 12,7392 \\
& ${\text { Prob }>\mathrm{Chi}^{2}}$ & 0,17941 & 0,72555 & 0,67854 & 0,96414 & 0,0102 & 0,17477 \\
\hline ii & $\mathrm{Chi}^{2}$ & 18,5340 & 7,4389 & 8,4883 & 8,4038 & 25,5234 & 21,4522 \\
& $\mathrm{Prob}^{2} \mathrm{Chi}^{2}$ & 0,2936 & 0,9639 & 0,9330 & 0,9359 & 0,0611 & 0,1618 \\
\hline iii & $\mathrm{Chi}^{2}$ & 14,8197 & 16,1727 & 15,0544 & 7,3528 & 23,8425 & 27,5568 \\
& Prob $>\mathrm{Chi}^{2}$ & 0,5379 & 0,4410 & 0,5207 & 0,9659 & 0,0930 & 0,0357 \\
\hline
\end{tabular}

Fonte: cálculos próprios. Nota: (1) $\mathrm{O}$ modelo i corresponde à relação entre investimento, crédito e retorno esperado do capital; o modelo ii corresponde a relação entre investimento, crédito, retorno esperado do capital e taxa de câmbio real e o modelo iii corresponde à relação entre investimento, crédito, retorno esperado do capital e preço relativo do capital.

Tabela A.6.3.4 Avaliação de normalidade dos resíduos

\begin{tabular}{|c|c|c|c|c|c|c|c|}
\hline \multirow[b]{2}{*}{ Modelo ${ }^{1}$} & \multirow[b]{2}{*}{ Prob $>\mathrm{Chi}^{2}$} & \multicolumn{6}{|c|}{ Variáveis } \\
\hline & & Investimento & $\begin{array}{r}\text { Crédito do } \\
\text { Bndes }\end{array}$ & PMK & $\begin{array}{r}\text { Taxa de } \\
\text { Câmbio real }\end{array}$ & $\begin{array}{r}\text { Preço relati- } \\
\text { vo }\end{array}$ & Conjunto \\
\hline \multirow{3}{*}{ i } & Jarque-Bera & 0,9874 & 0,1982 & 0,1197 & & & 0,2764 \\
\hline & Assimetria & 0,9328 & 0,0741 & 0,0772 & & & 0,0970 \\
\hline & Curtose & 0,8923 & 0,8287 & 0,2892 & & & 0,7558 \\
\hline \multirow{3}{*}{ ii } & Jarque-Bera & 0,9504 & 0,5811 & 0,1141 & 0,3491 & & 0,4700 \\
\hline & Assimetria & 0,7507 & 0,3342 & 0,0799 & 0,2444 & & 0,2437 \\
\hline & Curtose & 0,9770 & 0,6958 & 0,2588 & 0,3865 & & 0,7030 \\
\hline \multirow{3}{*}{ iii } & Jarque-Bera & 0,8831 & 0,1471 & 0,1184 & & 0,0000 & 0,0000 \\
\hline & Assimetria & 0,7667 & 0,0692 & 0,0417 & & 0,3871 & 0,0817 \\
\hline & Curtose & 0,6886 & 0,4658 & 0,7293 & & 0,0000 & 0,0000 \\
\hline
\end{tabular}

Fonte: cálculos próprios. Nota: (1) O modelo i corresponde à relação entre investimento, crédito e retorno esperado do capital; o modelo ii corresponde a relação entre investimento, crédito, retorno esperado do capital e taxa de câmbio real e o modelo iii corresponde à relação entre investimento, crédito, retorno esperado do capital e preço relativo do capital.

Tabela A.6.3.5. Resultados da regressão por diferenças

\begin{tabular}{|c|c|c|c|c|c|}
\hline Modelo ${ }^{1}$ & Estatística & Crédito (In) & $\begin{array}{r}\text { Retorno } \\
\text { esperado } \\
\text { do capital }\end{array}$ & $\begin{array}{r}\text { Taxa real } \\
\text { de câmbio }\end{array}$ & $\begin{array}{r}\text { Preço } \\
\text { relativo } \\
\text { do capital }\end{array}$ \\
\hline \multirow{3}{*}{ i } & $\beta$ & 0,1279 & 3,9640 & & \\
\hline & p-valor & 0,0020 & 0,0000 & & \\
\hline & $\mathrm{R}^{2}$ ajustado & 0,3158 & & & \\
\hline \multirow{3}{*}{ ii } & $\beta$ & 0,1201 & 3,9353 & $-0,1963$ & \\
\hline & $\mathrm{p}$-valor & 0,0020 & 0,0000 & 0,0080 & \\
\hline & $\mathrm{R}^{2}$ ajustado & 0,3867 & & & \\
\hline \multirow{3}{*}{ iii } & $\beta$ & 0,1523 & 3,8357 & & 0,2375 \\
\hline & $\mathrm{p}$-valor & 0,0000 & 0,0000 & & 0,0890 \\
\hline & $\mathrm{R}^{2}$ ajustado & 0,3390 & & & \\
\hline
\end{tabular}

Fonte: Cálculos próprios. Número de observações $=60$. Nota: (1) O modelo i corresponde à relação entre investimento, crédito e retorno esperado do capital; o modelo ii corresponde a relação entre investimento, crédito, retorno esperado do capital e taxa de câmbio real e o modelo iii corresponde à relação entre investimento, crédito, retorno esperado do capital e preço relativo do capital. 


\section{Apêndice 6.4 Descrição do teste de raiz unitária e de cointegração com quebra estrutural}

O teste de Zivot e Andrews (1992) considera a quebra estrutural como endógena no sentido que ela é um ponto desconhecido. O teste consiste na aplicação de um teste do tipo ADF em três modelos possíveis. A equação (A.15) é uma modificação da equação (A.12) a qual inclui a variável dummy $D_{1}(\lambda)$, em que $\lambda$ é uma fração do ponto de quebra $\left(\lambda=n_{\text {quebra }} / n\right)$. São feitas várias regressões em que $D_{1}(\lambda)$ muda a cada instante de $t$, e aplicado o teste de raiz unitária a cada instante. O teste de raiz unitária de Zivot e Andrews é o mínimo de toda a sequência de testes-t.

(A.15) $\Delta y_{t}=\alpha+\theta_{1} D_{1 t}(\lambda)+\beta t+\not y_{t-1}+\sum_{i=1}^{p} \delta_{i} \Delta y_{t-i}+\varepsilon_{t}$.

A hipótese nula é de que $y_{t}$ é integrado sem quebra estrutural. Contra três possíveis hipóteses alternativas, uma para cada modelo. A equação (A.15) representa o primeiro modelo em que a hipótese alternativa é de que $y_{t}$ pode ser representado por um processo estacionário com uma quebra estrutural no intercepto num ponto do tempo desconhecido. Os dois outros modelos incluem uma dummy para o coeficiente de inclinação da tendência e outra para a tendência. Assim, as hipóteses alternativas são, respectivamente: $y_{t}$ pode ser representado por um processo estacionário com uma quebra no coeficiente de inclinação da tendência num ponto do tempo desconhecido; e $y_{t}$ pode ser representado por um processo estacionário com uma quebra no intercepto e na inclinação da tendência num ponto do tempo desconhecido.

O teste de cointegração de Gregory e Hansem (1996) também considera a possibilidade de uma quebra endógena. A hipótese nula do teste é a mesma do teste convencional, ou seja, de não cointegração, enquanto que a hipótese alternativa, avalia a cointegração na presença de uma possível mudança de regime. A possibilidade de testar um ponto desconhecido no tempo, previne análises informais de séries que examinam visualmente e escolhe um ponto de quebra de forma arbitrária. Para modelar a quebra estrutural é necessário definir a variável dummy:

$$
\varphi_{t \tau}=\left\{\begin{array}{c}
0 \text { se } t \leq[n \tau] \\
1 \text { se } t>[n \tau]
\end{array} .\right.
$$

em que o parâmetro desconhecido $\tau \in(0,1)$ representa o ponto de mudança. São modeladas três formas de quebra estrutural. O modelo 1 prevê uma mudança de nível na relação de cointegração, que é modelada como uma mudança de intercepto em $\mu$ :

(A.16) $y_{t}=\mu_{1}+\mu_{2} \varphi_{t \tau}+\alpha x_{t}+\varepsilon_{t}, t=1, \ldots, n$.

em que $\mu_{1}$ representa o intercepto antes da mudança e $\mu_{2}$ representa o intercepto depois da mudança. O modelo 2 introduz uma tendência no modelo 1: 
(A.17) $y_{t}=\mu_{1}+\mu_{2} \varphi_{t \tau}+\beta t+\alpha x_{t}+\varepsilon_{t}, t=1, \ldots, n$.

O modelo 3 inclui uma mudança de inclinação do vetor de cointegração. Isso permite que a relação de equilíbrio gire ao invés de deslocar paralelamente:

(A.18) $y_{t}=\mu_{1}+\mu_{2} \varphi_{t \tau}+\beta t+\alpha_{1} x_{t}+\alpha_{2} x_{t} \varphi_{t \tau}+\varepsilon_{t}, t=1, \ldots, n$.

em que $\mu_{1}$ e $\mu_{2}$ são os mesmos do modelo $2, \alpha_{1}$ é o coeficiente de inclinação antes da mudança e $\alpha_{2}$ o coeficiente de inclinação depois da mudança.

Se o ponto $\tau$ fosse conhecido, poder-se-ia estimar os modelos por MQO e aplicar o teste ADF convencional nos resíduos. Contudo, $\tau$ não é conhecido. Gregory e Hansem (1996) desenvolveram um procedimento que computa um teste para cada ponto de mudança de regime $\tau \in T$ e pega o menor valor (ou o maior valor negativo) ao longo de todos os possíveis pontos de quebra. Como $T$ contém incontáveis pontos, todas as estatísticas consideradas são função step em $T$, pegando intervalos somente no ponto $\{\mathrm{i} / \mathrm{n}$, i é um inteiro $\}$. Os autores computaram três testes estatísticos, dois baseados nas estatísticas de Phillips : $Z_{\alpha}$ e $Z_{\mathrm{t}}$ e o outro na estatística de Dickey e Fuller: ADF. Por meio de simulações, os autores computaram os novos valores críticos para o teste.

\section{Apêndice 6.5. Tabelas complementares da análise com quebra estrutural}

Tabela A.6.5.1. Resultados da regressão por MQO

\begin{tabular}{|c|c|c|c|c|c|}
\hline Modelo & Estatística & Crédito (In) & $\begin{array}{r}\text { Retorno } \\
\text { esperado } \\
\text { do capital }\end{array}$ & $\begin{array}{l}\text { Taxa real } \\
\text { de câmbio }\end{array}$ & $\begin{array}{r}\text { Preço } \\
\text { relativo } \\
\text { do capital } \\
\end{array}$ \\
\hline \multirow{3}{*}{ i } & $\beta$ & 0,9636 & 12,09125 & & \\
\hline & p-valor & 0,0000 & 0,0000 & & \\
\hline & $\mathrm{R}^{2}$ ajustado & 0,9993 & & & \\
\hline \multirow{3}{*}{ ii } & $\beta$ & 0,9415 & 9,1524 & 1,1689 & \\
\hline & $\mathrm{p}$-valor & 0,0000 & 0,0000 & 0,0000 & \\
\hline & $\mathrm{R}^{2}$ ajustado & 0,9994 & & & \\
\hline \multirow{3}{*}{ iii } & $\beta$ & 0,8741 & 8,3191 & & 2,7791 \\
\hline & p-valor & 0,0000 & 0,0000 & & 0,0000 \\
\hline & $\mathrm{R}^{2}$ ajustado & 0,9995 & & & \\
\hline
\end{tabular}




\section{Apêndice 7.1. Tabelas complementares da análise do painel setorial}

\section{Tabela A.7.1.1 Compatibilização das bases de dados do WIOD e do BNDES para cálculo da distribuição do crédito de longo prazo entre setores de atividade na economia brasileira}

\begin{tabular}{|c|c|c|c|}
\hline $\begin{array}{l}\text { Código } \\
\text { WIOD }\end{array}$ & Setores WIOD & $\begin{array}{l}\text { Código } \\
\text { CNAE1 }\end{array}$ & Setores CNAE \\
\hline $\mathrm{c} 1$ & Agriculture, Hunting, Forestry and Fishing & A & Agropecuária \\
\hline c2 & Mining and Quarrying & $\mathrm{B}$ & Indústria Extrativa \\
\hline c3 & Food, Beverages and Tobacco & $\begin{array}{l}\mathrm{C} 10+\mathrm{C} 11 \\
+\mathrm{C} 12\end{array}$ & Produtos Alimentícios + Bebidas + fumo \\
\hline $\mathrm{c} 4$ & Textiles and textile & $\mathrm{C} 13+\mathrm{C} 14$ & Têxtil + Confec, vestuário e acessórios \\
\hline c5 & Leather, leather and footwear & C15 & Couro, artefato e calçado \\
\hline c6 & Wood and Products of Wood and Cork & C16 & Madeira \\
\hline c7 & Pulp, Paper, Paper, Printing and Publishing & $\mathrm{C} 17+\mathrm{C} 18$ & Celulose e papel + Gráfica \\
\hline c8 & Coke, refined petroleum and nuclear fuel & C19 & Coque, petróleo e combustível \\
\hline c9 & Chemicals and chemical & $\mathrm{C} 20+\mathrm{C} 21$ & Química + Farmoquímico, farmacêutico \\
\hline $\mathrm{c} 10$ & Rubber and plastics & $\mathrm{C} 22$ & Borracha e plástico \\
\hline c11 & Other Non-Metallic Mineral & $\mathrm{C} 23$ & Mineral não metálico \\
\hline c12 & Basic Metals and Fabricated Metal & $\mathrm{C} 25+\mathrm{C} 24$ & Produto de metal + Metalurgia \\
\hline $\mathrm{c} 13$ & Machinery, Nec & $\mathrm{C} 28$ & Máquinas e equipamentos \\
\hline c14 & Electrical and Optical Equipment & $\mathrm{C} 26+\mathrm{C} 27$ & $\begin{array}{l}\text { Equip info, eletronico, ótico + Máq, apare- } \\
\text { lho eletrico }\end{array}$ \\
\hline c15 & Transport Equipment & $\mathrm{C} 29+\mathrm{C} 30$ & $\begin{array}{l}\text { Veículo, reboque e carroceria + Outros } \\
\text { equip transporte }\end{array}$ \\
\hline c16 & Manufacturing, Nec; Recycling & $\mathrm{C} 31+\mathrm{C} 32$ & Móveis + Produtos diversos \\
\hline c17 & Electricity, Gas and Water Supply & $\mathrm{D} 35+\mathrm{E}$ & Eletricidade e gás + Água, esgoto e lixo \\
\hline c18 & Construction & $\mathrm{F}$ & Construção \\
\hline $\begin{array}{l}c 19+c 20 \\
+c 21\end{array}$ & $\begin{array}{l}\text { Sale, maintenance and repair of motor vehicles and motor- } \\
\text { cycles; retail sale of fuel }+ \text { Wholesale trade and commis- } \\
\text { sion trade, except of motor vehicles and motorcycles + } \\
\text { Retail trade, except of motor vehicles and motorcycles; } \\
\text { repair of household goods }\end{array}$ & G & Comércio \\
\hline $\mathrm{c} 22$ & Hotels and Restaurants & I & Alojamento e alimentação \\
\hline c23 & Other Inland transport & $\mathrm{H} 49$ & Transporte terrestre \\
\hline c24 & Other Water transport & $\mathrm{H} 50$ & Transporte aquaviário \\
\hline $\mathrm{c} 25$ & Other Air transport & H51 & Transporte aéreo \\
\hline c26 & $\begin{array}{l}\text { Other Supporting and auxiliary transport activities; activities } \\
\text { of travel agencies }\end{array}$ & $\mathrm{H} 52+\mathrm{H} 53$ & Ativ aux transporte e entrega \\
\hline $\mathrm{c} 27$ & Post and Telecommunications & $J+J 61$ & $\begin{array}{l}\text { Informação e comunicação + Telecomuni- } \\
\text { cações }\end{array}$ \\
\hline $\mathrm{c} 28$ & Financial Intermediation & $\mathrm{K}$ & Ativ financeira e seguro \\
\hline $\mathrm{c} 29+\mathrm{c} 30$ & $\begin{array}{l}\text { Real estate activities + Renting of m\&eq and other business } \\
\text { activities }\end{array}$ & $L+M+N$ & Ativ imobil, profissional e adm \\
\hline c31 & Public Admin and Defence; Compulsory Social Security & $\mathrm{O}$ & Administração Pública \\
\hline c32 & Education & $P$ & Educação \\
\hline c33 & Health and Social Work & Q & Saúde e serv social \\
\hline c34 & Other Community, Social and Personal Services & $\begin{array}{l}\mathrm{R}+\mathrm{S}+\mathrm{T}+ \\
\mathrm{C} 33+\mathrm{U}\end{array}$ & $\begin{array}{l}\text { Artes, cultura e esporte + Outras ativ } \\
\text { serviços + Manutenção, reparação, instal. } \\
+ \text { Organismos internacionais }\end{array}$ \\
\hline
\end{tabular}

Fonte: WIOD e BNDES. Nota: (1) CNAE: Seção e Divisão. 


\section{Apêndice 7.2. Resultados da fronteira para cálculo do retorno esperado do capital}

O modelo de fronteira estocástica foi estimado para um painel formado por 31 setores de atividades, com observações anuais para o período 1995 a 2009, num total de 465 observações. Os setores de atividade são descritos na Tabela A.7.1.1. A estimação seguiu as premissas do Apêndice 3.1, em que a ineficiência tem distribuição normal truncada com média condicional ao número de horas trabalhadas por empregado. A seguir são apresentadas as descrições das variáveis:

- Valor adicionado: corresponde ao Valor adicionado em dólares constantes de 1995. A variável foi transformada em logaritmo natural (ln). A fonte é o WIOD.

- Estoque de capital: corresponde ao estoque de capital dos setores em US\$ constantes de 1995. A variável também foi transformada em $l n$.

- Força de trabalho: corresponde a população com 15 anos de idade ou mais velhos que oferta trabalho para a produção de mercadorias e serviços do país. Inclui empregados e desempregados. Em geral, inclui as pessoas que trabalham nas forças armadas e exclui as donas de casa, os trabalhadores que não recebem salário e o trabalho informal. Essa variável também foi transformada em $\ln$. A fonte é o WIOD.

- Horas trabalhadas: corresponde ao número de horas trabalhadas em cada economia. A fonte é o WIOD.

O resultado da estimação da fronteira estocástica para esse painel é apresentado na Tabela A.7.2.1. Nota-se que todos os coeficientes estimados apresentam os sinais esperados e são estatisticamente significantes.

Tabela A.7.2.1 Resultado da Fronteira Estocástica

\begin{tabular}{|c|c|c|c|c|c|c|}
\hline \multirow{2}{*}{$\frac{\mathrm{Y}}{\mathrm{K}}$} & \multirow{2}{*}{$\begin{array}{r}\text { Coeficiente } \\
0,5415\end{array}$} & \multirow{2}{*}{$\begin{array}{r}\text { Desvio Padrão } \\
0,0431\end{array}$} & \multirow{2}{*}{$\frac{z}{12,56}$} & \multirow{2}{*}{$\frac{\text { P-valor }}{0,0000}$} & \multicolumn{2}{|c|}{$\begin{array}{c}\text { Intervalo de Confiança } \\
(95 \%)\end{array}$} \\
\hline & & & & & 0,4570 & 0,6261 \\
\hline $\mathrm{N}$ & 0,2990 & 0,0366 & 8,16 & 0,0000 & 0,2272 & 0,3709 \\
\hline $\mathrm{t}$ & $-0,0367$ & 0,0440 & $-0,84$ & 0,4040 & $-0,1229$ & 0,0494 \\
\hline $\mathrm{KK}^{2}$ & $-0,1542$ & 0,0383 & $-4,02$ & 0,0000 & $-0,2293$ & $-0,0791$ \\
\hline $\mathrm{KN}$ & 0,0344 & 0,0296 & 1,16 & 0,2460 & $-0,0237$ & 0,0924 \\
\hline $\mathrm{Kt}$ & $-0,0013$ & 0,0051 & $-0,26$ & 0,7960 & $-0,0114$ & 0,0087 \\
\hline $\mathrm{NN}^{2}$ & $-0,0653$ & 0,0269 & $-2,43$ & 0,0150 & $-0,1180$ & $-0,0127$ \\
\hline $\mathrm{Nt}$ & 0,0131 & 0,0046 & 2,82 & 0,0050 & 0,0040 & 0,0221 \\
\hline $\mathrm{tt}^{2}$ & 0,0186 & 0,0083 & 2,25 & 0,0240 & 0,0024 & 0,0348 \\
\hline constante & 0,3485 & 0,0848 & 4,11 & 0,0000 & 0,1823 & 0,5148 \\
\hline \multicolumn{7}{|l|}{ Média de $u$} \\
\hline $\mathrm{t}$ & 0,2183 & 0,0618 & 3,53 & 0,0000 & 0,0971 & 0,3395 \\
\hline $\mathrm{H} \_\mathrm{N}$ & $-1,3230$ & 0,5823 & $-2,27$ & 0,0230 & $-2,4642$ & $-0,1818$ \\
\hline constante & $-1,2378$ & 0,5144 & $-2,41$ & 0,0160 & $-2,2460$ & $-0,2295$ \\
\hline $\ln \sigma_{v}^{2}$ & $-1,2264$ & 0,0982 & $-12,49$ & 0,0000 & $-1,4189$ & $-1,0339$ \\
\hline $\ln \sigma^{2}{ }_{u}$ & $-0,0909$ & 0,3740 & $-0,24$ & 0,8080 & $-0,8239$ & 0,6420 \\
\hline$\sigma_{\mathrm{v}}$ & 0,2933 & 0,0288 & & & & \\
\hline$\sigma_{\mathrm{u}}$ & 0,4773 & 0,0933 & & & & \\
\hline$\sigma^{2}$ & 0,1400 & 0,0371 & & & & \\
\hline$\lambda$ & 0,1533 & 0,0222 & & & & \\
\hline
\end{tabular}




\section{Apêndice 7.3. Tabelas complementares de cointegração}

Tabela A.7.3.1. Resultados da estimação por efeito fixo

\begin{tabular}{lrrr}
\hline & Coeficiente & $\mathrm{t}$ & $\mathrm{p}$-valor \\
\hline Crédito (In) & 0,1426 & 9,34 & 0,0000 \\
Retorno do Capital & 0,1629 & 4,22 & 0,0000 \\
Preço relativo do capital & $-1,1676$ & $-16,38$ & 0,0000 \\
constante & 20,0571 & 60,1 & 0,0000 \\
\hline$\sigma_{u}$ & 1,2229 & \\
$\sigma_{e}$ & 0,2434 & \\
$\rho$ & 0,9619 & \\
\hline $\mathrm{R}^{2}$ overall & 0,0876 & \\
Número de observações & 465 & \\
\hline
\end{tabular}

Fonte: Cálculos próprios. Variável dependente: Investimento (ln).

Tabela A.7.3.2. Resultados da estimação por efeito fixo

\begin{tabular}{|c|c|c|c|}
\hline & Coeficiente & $\mathrm{t}$ & $\mathrm{p}$-valor \\
\hline \multicolumn{4}{|c|}{ Relação entre investimento, retorno do capital, preço relativo do capital e taxa de juros } \\
\hline Crédito (In) & 0,0866 & 6,0500 & 0,0000 \\
\hline Retorno do Capital & 0,1630 & 4,8000 & 0,0000 \\
\hline Preço relativo do capital & $-0,8931$ & $-13,2900$ & 0,0000 \\
\hline Taxa de juros de longo prazo & $-3,3187$ & $-11,3100$ & 0,0000 \\
\hline constante & 21,3001 & 67,9900 & 0,0000 \\
\hline$\sigma_{u}$ & 1,2372 & & \\
\hline$\sigma_{e}$ & 0,2139 & & \\
\hline$\rho$ & 0,9710 & & \\
\hline $\mathrm{R}^{2}$ overall & 0,0743 & & \\
\hline Número de observações: & 465 & & \\
\hline \multicolumn{4}{|c|}{ Relação entre investimento, retorno do capital, preço relativo do capital, taxa de juros e taxa de câmbio } \\
\hline Crédito (In) & 0,0664 & 4,8100 & 0,0000 \\
\hline Retorno do Capital & 0,1925 & 5,9500 & 0,0000 \\
\hline Preço relativo do capital & $-0,7636$ & $-11,5800$ & 0,0000 \\
\hline Taxa de juros de longo prazo & $-3,9410$ & $-13,5800$ & 0,0000 \\
\hline Taxa real de câmbio & 0,3468 & 7,2500 & 0,0000 \\
\hline constante & 21,3680 & 72,1500 & 0,0000 \\
\hline$\sigma_{u}$ & 1,2463 & & \\
\hline$\sigma_{e}$ & 0,2022 & & \\
\hline$\rho$ & 0,9744 & & \\
\hline $\mathrm{R}^{2}$ overall & 0,065 & & \\
\hline Número de observações: & 465 & & \\
\hline \multicolumn{4}{|c|}{ Relação entre investimento, retorno esperado do capital, preço relativo do capital, taxa de juros e taxa de câmbio } \\
\hline Crédito (In) & 0,0682 & 4,7700 & 0,0000 \\
\hline Retorno do Capital & 0,2705 & 2,3500 & 0,0190 \\
\hline Preço relativo do capital & $-0,8532$ & $-12,9200$ & 0,0000 \\
\hline Taxa de juros de longo prazo & $-4,0669$ & $-13,0900$ & 0,0000 \\
\hline Taxa real de câmbio & 0,3221 & 6,5400 & 0,0000 \\
\hline constante & 21,4152 & 69,0300 & 0,0000 \\
\hline$\sigma_{u}$ & 1,2575 & & \\
\hline$\sigma_{e}$ & 0,2090 & & \\
\hline$\rho$ & 0,9731 & & \\
\hline $\mathrm{R}^{2}$ overall & 0,0495 & & \\
\hline Número de observações: & 465 & & \\
\hline
\end{tabular}




\section{Apêndice 7.4. Tabelas complementares de contabilidade de crescimento}

Tabela A.7.4.1 Decomposição do Crescimento do PIB por setor, Brasil, 1995 a 2002 (\% ao ano)

\begin{tabular}{|c|c|c|c|c|}
\hline Setor & $g_{Y}$ & $g_{A}$ & $s_{K} \cdot g_{K}$ & $s_{N} \cdot g_{N}$ \\
\hline Agropecuária & $4,13 \%$ & $0,66 \%$ & $4,01 \%$ & $-0,53 \%$ \\
\hline Indústria Extrativa & $4,11 \%$ & $-11,37 \%$ & $15,75 \%$ & $-0,26 \%$ \\
\hline Produtos Alimentícios, bebidas e fumo & $2,75 \%$ & $-0,87 \%$ & $3,39 \%$ & $0,23 \%$ \\
\hline Têxtil, confec., vestuário e acessórios & $-0,81 \%$ & $-0,37 \%$ & $-0,19 \%$ & $-0,25 \%$ \\
\hline Couro, artefato e calçado & $-0,96 \%$ & $-4,49 \%$ & $1,57 \%$ & $1,95 \%$ \\
\hline Madeira & $-0,87 \%$ & $-8,39 \%$ & $7,26 \%$ & $0,26 \%$ \\
\hline Celulose, papel e gráfica & $2,11 \%$ & $-8,98 \%$ & $12,14 \%$ & $-1,06 \%$ \\
\hline Coque, petróleo e combustível & $9,68 \%$ & $-7,07 \%$ & $17,64 \%$ & $-0,89 \%$ \\
\hline Química, farmoquímico e farmacêutico & $8,89 \%$ & $6,27 \%$ & $3,63 \%$ & $-1,00 \%$ \\
\hline Borracha e plástico & $-2,25 \%$ & $-6,17 \%$ & $2,84 \%$ & $1,09 \%$ \\
\hline Mineral não metálico & $0,37 \%$ & $0,21 \%$ & $-0,10 \%$ & $0,26 \%$ \\
\hline Produto de metal e metalurgia & $3,71 \%$ & $-1,21 \%$ & $4,51 \%$ & $0,41 \%$ \\
\hline Máquinas e equipamentos & $4,06 \%$ & $1,81 \%$ & $1,52 \%$ & $0,73 \%$ \\
\hline Equip. info. eletrônico, ótico, máquinas e aparelho elétrico & $1,01 \%$ & $0,98 \%$ & $-0,04 \%$ & $0,08 \%$ \\
\hline Veículo, reboque, carroceria e outros equip. transporte & $5,36 \%$ & $0,61 \%$ & $3,45 \%$ & $1,31 \%$ \\
\hline Móveis e produtos diversos & $3,62 \%$ & $3,09 \%$ & $0,38 \%$ & $0,14 \%$ \\
\hline Eletricidade, gás, água, esgoto e lixo & $1,59 \%$ & $0,91 \%$ & $1,00 \%$ & $-0,32 \%$ \\
\hline Construção & $1,03 \%$ & $-2,45 \%$ & $2,07 \%$ & $1,41 \%$ \\
\hline Comércio & $0,83 \%$ & $-0,50 \%$ & $-0,35 \%$ & $1,68 \%$ \\
\hline Alojamento e alimentação & $7,79 \%$ & $0,53 \%$ & $5,45 \%$ & $1,81 \%$ \\
\hline Transporte terrestre & $0,92 \%$ & $-1,00 \%$ & $-0,29 \%$ & $2,20 \%$ \\
\hline Transporte aquaviário & $0,92 \%$ & $0,56 \%$ & $-0,53 \%$ & $0,89 \%$ \\
\hline Transporte aéreo & $0,92 \%$ & $-0,85 \%$ & $-0,31 \%$ & $2,08 \%$ \\
\hline Ativ. Aux. transporte e entrega & $0,92 \%$ & $-0,30 \%$ & $-0,40 \%$ & $1,62 \%$ \\
\hline Informação, comunicação e telecomunicações & $10,18 \%$ & $5,32 \%$ & $2,24 \%$ & $2,61 \%$ \\
\hline Ativ. financeira e seguro & $1,23 \%$ & $6,88 \%$ & $-5,50 \%$ & $-0,16 \%$ \\
\hline Ativ. Imobil., profissional e adm. & $2,62 \%$ & $0,94 \%$ & $1,07 \%$ & $0,61 \%$ \\
\hline Administração Pública & $2,47 \%$ & $-0,96 \%$ & $0,25 \%$ & $3,18 \%$ \\
\hline Educação & $2,28 \%$ & $-0,21 \%$ & $-0,27 \%$ & $2,76 \%$ \\
\hline Saúde e serv. social & $2,39 \%$ & $-1,92 \%$ & $2,27 \%$ & $2,04 \%$ \\
\hline Artes, cultura etc. ${ }^{*}$ & $2,31 \%$ & $-0,84 \%$ & $1,12 \%$ & $2,03 \%$ \\
\hline Total & $2,49 \%$ & $0,25 \%$ & $1,38 \%$ & $0,87 \%$ \\
\hline
\end{tabular}

Fonte: WIOD e BNDES. Cálculos próprios. (*) Para simplificar a exposição dos resultados, a taxa $g_{A}$ inclui a variação da ineficiência $u$ definida nas equações do Capítulo 2 . 
Tabela A.7.4.2 Decomposição do Crescimento do PIB por setor, Brasil, 2002 a 2009 (\% ao ano)

\begin{tabular}{|c|c|c|c|c|}
\hline Setor & $g_{Y}$ & $g_{A}$ & $s_{K} \cdot g_{K}$ & $S_{N} \cdot g_{N}$ \\
\hline Agropecuária & $2,99 \%$ & $-1,04 \%$ & $4,21 \%$ & $-0,17 \%$ \\
\hline Indústria Extrativa & $3,76 \%$ & $-8,66 \%$ & $11,74 \%$ & $0,68 \%$ \\
\hline Produtos Alimentícios, bebidas e fumo & $1,43 \%$ & $-4,30 \%$ & $2,70 \%$ & $3,03 \%$ \\
\hline Têxtil, confec., vestuário e acessórios & $-0,27 \%$ & $-2,76 \%$ & $1,00 \%$ & $1,49 \%$ \\
\hline Couro, artefato e calçado & $-2,99 \%$ & $-5,83 \%$ & $1,68 \%$ & $1,16 \%$ \\
\hline Madeira & $-2,53 \%$ & $-7,02 \%$ & $4,53 \%$ & $-0,05 \%$ \\
\hline Celulose, papel e gráfica & $3,30 \%$ & $-5,28 \%$ & $7,25 \%$ & $1,33 \%$ \\
\hline Coque, petróleo e combustível & $1,87 \%$ & $-13,52 \%$ & $11,98 \%$ & $3,42 \%$ \\
\hline Química, farmoquímico e farmacêutico & $2,42 \%$ & $-3,15 \%$ & $4,29 \%$ & $1,28 \%$ \\
\hline Borracha e plástico & $1,17 \%$ & $-4,65 \%$ & $2,75 \%$ & $3,07 \%$ \\
\hline Mineral não metálico & $3,00 \%$ & $-0,64 \%$ & $1,89 \%$ & $1,75 \%$ \\
\hline Produto de metal e metalurgia & $0,31 \%$ & $-7,14 \%$ & $5,80 \%$ & $1,65 \%$ \\
\hline Máquinas e equipamentos & $3,63 \%$ & $-2,99 \%$ & $2,56 \%$ & $4,06 \%$ \\
\hline Equip. info. eletrônico, ótico, máquinas e aparelho elétrico & $2,16 \%$ & $-3,82 \%$ & $2,64 \%$ & $3,35 \%$ \\
\hline Veículo, reboque, carroceria e outros equip. transporte & $5,04 \%$ & $-1,94 \%$ & $2,25 \%$ & $4,74 \%$ \\
\hline Móveis e produtos diversos & $1,14 \%$ & $-2,56 \%$ & $2,54 \%$ & $1,16 \%$ \\
\hline Eletricidade, gás, água, esgoto e lixo & $4,22 \%$ & $-1,19 \%$ & $4,78 \%$ & $0,64 \%$ \\
\hline Construção & $3,05 \%$ & $-0,44 \%$ & $1,94 \%$ & $1,55 \%$ \\
\hline Comércio & $4,22 \%$ & $2,57 \%$ & $0,27 \%$ & $1,38 \%$ \\
\hline Alojamento e alimentação & $4,83 \%$ & $1,83 \%$ & $2,08 \%$ & $0,92 \%$ \\
\hline Transporte terrestre & $-1,44 \%$ & $-3,87 \%$ & $1,65 \%$ & $0,78 \%$ \\
\hline Transporte aquaviário & $-7,27 \%$ & $-9,79 \%$ & $1,12 \%$ & $1,40 \%$ \\
\hline Transporte aéreo & $-6,47 \%$ & $-6,69 \%$ & $0,80 \%$ & $-0,58 \%$ \\
\hline Ativ. Aux. transporte e entrega & $-0,69 \%$ & $-4,68 \%$ & $2,45 \%$ & $1,54 \%$ \\
\hline Informação, comunicação e telecomunicações & $2,61 \%$ & $-5,13 \%$ & $7,02 \%$ & $0,72 \%$ \\
\hline Ativ. financeira e seguro & $6,70 \%$ & $3,88 \%$ & $2,34 \%$ & $0,49 \%$ \\
\hline Ativ. Imobil., profissional e adm. & $4,21 \%$ & $1,74 \%$ & $1,22 \%$ & $1,25 \%$ \\
\hline Administração Pública & $2,91 \%$ & $-0,30 \%$ & $0,56 \%$ & $2,66 \%$ \\
\hline Educação & $0,52 \%$ & $-2,73 \%$ & $-0,06 \%$ & $3,31 \%$ \\
\hline Saúde e serv. social & $3,84 \%$ & $-0,08 \%$ & $1,36 \%$ & $2,55 \%$ \\
\hline Artes, cultura etc.* & $3,67 \%$ & $-0,87 \%$ & $2,77 \%$ & $1,77 \%$ \\
\hline Total & $3,32 \%$ & $-0,23 \%$ & $2,33 \%$ & $1,22 \%$ \\
\hline
\end{tabular}

Fonte: WIOD e BNDES. Cálculos próprios. $\left.{ }^{*}\right)$ Para simplificar a exposição dos resultados, a taxa $g_{A}$ inclui a variação da ineficiência u definida nas equações do Capítulo 2. 
Tabela A.7.4.3 Variações observadas e esperadas na taxa crescimento econômico, por setor, Brasil, 1995 a 2002 contra 2002 a 2009, pontos percentuais

\begin{tabular}{|c|c|c|c|}
\hline Setor & Esperado & Observado & Diferença \\
\hline Agropecuária & 3,60 p.p. & $-1,14$ p.p. & 4,74 p.p. \\
\hline Indústria Extrativa & 22,85 p.p. & $-0,36$ p.p. & 23,20 p.p. \\
\hline Produtos Alimentícios, bebidas e fumo & 2,66 p.p. & $-1,32$ p.p. & 3,98 p.p. \\
\hline Têxtil, confec., vestuário e acessórios & 0,85 p.p. & 0,54 p.p. & 0,31 p.p. \\
\hline Couro, artefato e calçado & 1,90 p.p. & $-2,02$ p.p. & 3,92 p.p. \\
\hline Madeira & 5,45 p.p. & $-1,66$ p.p. & 7,11 p.p. \\
\hline Celulose, papel e gráfica & 20,51 p.p. & 1,19 p.p. & 19,31 p.p. \\
\hline Coque, petróleo e combustível & 20,74 p.p. & $-7,81$ p.p. & 28,55 p.p. \\
\hline Química, farmoquímico e farmacêutico & 3,54 p.p. & $-6,47$ p.p. & 10,01 p.p. \\
\hline Borracha e plástico & 3,31 p.p. & 3,42 p.p. & $-0,11$ p.p. \\
\hline Mineral não metálico & 1,49 p.p. & 2,63 p.p. & $-1,14$ p.p. \\
\hline Produto de metal e metalurgia & 5,72 p.p. & $-3,40$ p.p. & 9,12 p.p. \\
\hline Máquinas e equipamentos & 2,26 p.p. & $-0,43$ p.p. & 2,69 p.p. \\
\hline Equip. info. eletrônico, ótico, máquinas e aparelho elétrico & 1,80 p.p. & 1,15 p.p. & 0,65 p.p. \\
\hline Veículo, reboque, carroceria e outros equip. transporte & 3,22 p.p. & $-0,32$ p.p. & 3,54 p.p. \\
\hline Móveis e produtos diversos & 1,74 p.p. & $-2,48$ p.p. & 4,22 p.p. \\
\hline Eletricidade, gás, água, esgoto e lixo & 3,42 p.p. & 2,63 p.p. & 0,79 p.p. \\
\hline Construção & 1,84 p.p. & 2,02 p.p. & $-0,18$ p.p. \\
\hline Comércio & 0,98 p.p. & 3,39 p.p. & $-2,42$ p.p. \\
\hline Alojamento e alimentação & 2,47 p.p. & $-2,97$ p.p. & 5,44 p.p. \\
\hline Transporte terrestre & 1,38 p.p. & $-2,36$ p.p. & 3,74 p.p. \\
\hline Transporte aquaviário & 1,93 p.p. & $-8,19$ p.p. & 10,12 p.p. \\
\hline Transporte aéreo & 1,39 p.p. & $-7,38$ p.p. & 8,77 p.p. \\
\hline Ativ. Aux. transporte e entrega & 1,92 p.p. & $-1,61$ p.p. & 3,53 p.p. \\
\hline Informação, comunicação e telecomunicações & 9,54 p.p. & $-7,57$ p.p. & 17,11 p.p. \\
\hline Ativ. financeira e seguro & 7,17 p.p. & 5,47 p.p. & 1,71 p.p. \\
\hline Ativ. Imobil., profissional e adm. & 0,91 p.p. & 1,59 p.p. & $-0,68$ p.p. \\
\hline Administração Pública & 0,46 p.p. & 0,45 p.p. & 0,01 p.p. \\
\hline Educação & 0,07 p.p. & $-1,76$ p.p. & 1,83 p.p. \\
\hline Saúde e serv. social & 1,85 p.p. & 1,45 p.p. & 0,40 p.p. \\
\hline Artes, cultura etc. ${ }^{*}$ & 1,83 p.p. & 1,36 p.p. & 0,46 p.p. \\
\hline Total & 1,66 p.p. & 2,90 p.p. & $-1,25$ p.p. \\
\hline
\end{tabular}

Fonte: WIOD, BNDES e Banco Central do Brasil. Cálculos próprios. 
